\title{
Differentiated practice and specialization in community nursing
}

Citation for published version (APA):

Jansen, P. (1996). Differentiated practice and specialization in community nursing. [Doctoral Thesis, Maastricht University]. NIVEL. https://doi.org/10.26481/dis.19961217pj

Document status and date:

Published: 01/01/1996

DOI:

10.26481/dis.19961217pj

Document Version:

Publisher's PDF, also known as Version of record

\section{Please check the document version of this publication:}

- A submitted manuscript is the version of the article upon submission and before peer-review. There can be important differences between the submitted version and the official published version of record.

People interested in the research are advised to contact the author for the final version of the publication, or visit the DOI to the publisher's website.

- The final author version and the galley proof are versions of the publication after peer review.

- The final published version features the final layout of the paper including the volume, issue and page numbers.

Link to publication

\footnotetext{
General rights rights.

- You may freely distribute the URL identifying the publication in the public portal. please follow below link for the End User Agreement:

www.umlib.nl/taverne-license

Take down policy

If you believe that this document breaches copyright please contact us at:

repository@maastrichtuniversity.nl

providing details and we will investigate your claim.
}

Copyright and moral rights for the publications made accessible in the public portal are retained by the authors and/or other copyright owners and it is a condition of accessing publications that users recognise and abide by the legal requirements associated with these

- Users may download and print one copy of any publication from the public portal for the purpose of private study or research.

- You may not further distribute the material or use it for any profit-making activity or commercial gain

If the publication is distributed under the terms of Article $25 \mathrm{fa}$ of the Dutch Copyright Act, indicated by the "Taverne" license above, 


\section{DIFFERENTIATED PRACTICE AND SPECIALIZATION IN COMMUNITY NURSING}

Verticale en horizontale functiedifferentiatie

in de wijkverpleging 
CIP-GEGEVENS KONINKLIJKE BIBLIOTHEEK DEN HAAG

Jansen, P.G.M.

Differentiated practice and specialization in community nursing / P.G.M. Jansen -

Utrecht: NIVEL - Nederlands instituut voor onderzoek van de gezondheidszorg

Proefschrift Universiteit Maastricht - Met lit. opg. - Met samenvatting in het Nederlands.

ISBN 90-6905-306-3

Trefw.: functiedifferentiatie; complexiteit; toewijzingsinstrument

Wordprocessing and lay-out

Cover

Correction

Printing
Brigit Sluijk-Zonneveld Mieke Cornelius

S. Wadsworth

Boekbinderij Post 


\title{
DIFFERENTIATED PRACTICE AND SPECIALIZATION IN COMMUNITY NURSING
}

\author{
Verticale en horizontale functiedifferentiatie \\ in de wijkverpleging
}

\author{
PROEFSCHRIFT \\ ter verkrijging van de graad van doctor \\ aan de Universiteit Maastricht, \\ op gezag van de Rector Magnificus, Prof. mr. M.J. Cohen, \\ ingevolge het besluit van het College van Dekanen \\ in het openbaar te verdedigen op \\ dinsdag 17 december 1996 om 16.00 uur
}

door Patrick Gregorius Maria Jansen geboren op 21 juni 1964 te Beltrum 


\section{Promotoren:}

Prof. dr. H. Huijer Abu-Saad

Prof. dr. J. van der Zee

\section{Co-promotor:}

Dr. A. Kerkstra

\section{Beoordelingscommissie:}

Prof. dr. F.J.N. Nijhuis (voorzitter)

Prof. dr. H. Philipsen

Prof. dr. W.B. Schaufeli (Universiteit Utrecht)

Prof. dr. L. Shortridge (Universiteit Utrecht)

Prof. dr. F.C.B. van Wijmen

The study presented in this thesis was conducted at the Netherlands Institute of Primary Health Care (NIVEL), which participates in the Netherlands School of Primary Care Research (CaRe), acknowledged in 1995 by the Royal Dutch Academy of Science (KNAW).

This research was commissioned by the Dutch Association of Community Nurses (MVM). The study is financed by the Ministry of Health, Welfare and Sports and by the National Centre of Nursing \& Caring (LCW) in the Netherlands. 


\section{Contents}

\section{PART I}

Chapter 1: Introduction

1.1 Background to the study 1

1.2 Community nursing 2

1.3 Differentiated practice 3

1.4 Specialization 4

1.5 Job satisfaction, burnout and quality of care 5

1.6 Aim of the study 5

1.7 References 8

Chapter 2: $\quad$ Differentiated practice and specialization in community nursing: a descriptive study in the Netherlands

2.1 Summary 11

2.2 Introduction 12

$\begin{array}{lll}2.3 & \text { Review of the literature } & 12\end{array}$

2.3.1 Differentiated practice 13

2.3.2 Specialization 14

2.4 Method 15

2.5 Results 16

2.5.1 Differentiated practice 16

2.5.2 Specialization 19

2.6 Discussion 22

2.7 References 24

Chapter 3: $\quad$ Differentlated practice and speclalization in community nursing: a review of the literature 26

3.1 Summary 26

3.2 Introduction 26

3.2.1 Theoretical context 27

3.3 Method 29

$\begin{array}{lll}3.4 & \text { Results } & 29\end{array}$

3.4.1 Differentiated practice: the concept and models 29

3.4.2 Differentiated practice: the effects on job satisfaction 35

3.4.3 Differentiated practice: the effects on quality of care 37

3.4.4 Specialization: the concept and models 38

3.4.5 Specialization: the effects on job satisfaction 39

3.4.6 Specialization: the effects on quality of care 40 
3.5 Towards a model for evaluation of differentiated practice and specialization in community nursing 41

3.6 Discussion 43

3.7 References 45

PART II

Chapter 4: The effects of job characteristics and individual characteristics on job satisfaction and burnout in community nursing

4.1 Summary 50

4.2 Introduction 50

4.3 Review of the literature 51

4.3.1 Types of community nurse in the Netherlands 51

4.3.2 Job satisfaction 52

4.3.3 Burnout 53

4.4 Method 55

4.4.1 Subjects and procedure $\quad 55$

4.4.2 Measuring instruments 56

$\begin{array}{lll}4.5 & \text { Results } & 57\end{array}$

4.5.1 Differences in mean-scores on the variables between the two types of nurse

4.5.2 Effects of job characteristics on job satisfaction and burnout

4.5.3 Effects of individual characteristics on job satisfaction and burnout $\quad 61$

4.6 Discussion 64

$\begin{array}{lll}4.7 & \text { References } & 67\end{array}$

Chapter 5: Patient-assignment, an important element of differentiated practice in community nursing: difference between desirability and reality $\quad 70$

$\begin{array}{lll}5.1 & \text { Summary } & 70\end{array}$

5.2 Introduction 70

5.3 Study 1: Reliability and validity of the instrument for patient-assignment $\quad 72$

$\begin{array}{lll}\text { 5.3.1 Method } & 75\end{array}$

$\begin{array}{lll}\text { 5.3.2 Results } & 75\end{array}$

5.3.3 Conclusion 78

5.4 Study 2: Clinical utility and acceptability of

$\begin{array}{lll}\text { 5.4.1 Method } & 78\end{array}$ 
5.4.2 Results

5.5 Discussion 84

5.6 References 86

Chapter 6: $\quad$ Outcomes of differentiated practice and specialization on job characteristics, job satisfaction and burnout in community nursing $\quad 88$

6.1 Summary 88

6.2 Introduction 88

6.2.1 Expected outcomes of differentiated practice 91

6.2.2 Expected outcomes of specialization

(i.e. areas-of-special-expertise) 92

6.3 Method 93

6.3.1 Intervention 93

6.3.2 Sample 96

6.3.3 Measuring instruments 98

6.3.4 Analysis 100

6.4 Results 100

6.4.1 Changes in job characteristics related to

6.4.2 Changes in job satisfaction and burnout related to differentiated practice and specialization 101

6.4.3 Additional results: overall changes in job characteristics, job satisfaction and burnout $\quad 104$

6.5 Discussion 106

6.6 References 109

Chapter 7: $\quad$ Outcomes of differentiated practlce and specialization in community nursing on quality of care: viewed from the perspective of the patient 112

7.1 Summary

7.2 Introduction

7.2.1 Quality of care from the patients' perspective: theoretical background

7.2.2 Differentiated practice and specialization in relation to the quality of care

7.3 Method

7.3.1 Intervention

$\begin{array}{ll}7.3 .2 & \text { Research population } \\ 7.3 .3\end{array}$

$\begin{array}{ll}7.3 .3 & \text { Measuring instrument } \\ 7.3 .4 & 120\end{array}$

$\begin{array}{lll}7.3 .4 & \text { Analysis } & 122\end{array}$

$\begin{array}{lll}7.4 & \text { Results } & 123\end{array}$ 
$\begin{array}{lll}7.5 & \text { Discussion } & 128 \\ 7.6 & \text { References } & 130 \\ 7.7 & \text { Appendix } & 132\end{array}$

PART III

Chapter 8: $\quad$ General conclusions and discussion 134

8.1 Conclusions 134

8.2 Discussion 140

8.2.1 Methodological reflections 140

8.2.2 Theoretical reflections 144

8.2.3 Practical implications 150

8.2.4 Recommendations for future research 153

8.3 References 155

$\begin{array}{ll}\text { Summary } & 158\end{array}$

$\begin{array}{ll}\text { Samenvatting } & 163\end{array}$

$\begin{array}{ll}\text { References } & 169\end{array}$

$\begin{array}{ll}\text { Acknowledgements } & 179\end{array}$

$\begin{array}{ll}\text { About the author } & 181\end{array}$ 


\subsection{Background to the study}

The demand and supply of health care is continuously changing. Several developments are responsible for this including demographical and epidemiological changes, technological options, and changes in government policy. These changes have a great impact on the organization of care and require specific expertise of care givers. The consequences are described with regard to nursing in the community. Demographical statistics show that the number and percentage of the elderly is growing. For example, the expectation that between 1992 and 2010 the percentage of people over 65 will increase from $13 \%$ to $16 \%$ in the Netherlands and Europe, and from $13 \%$ to $15 \%$ in North America (Netherlands Central Bureau of Statistics, 1995). The demand for care will not only increase due to the numbers of elderly, but also because of the fact that the care for the elderly is more intensive (Kooiker et al., 1992). This change will have a great impact on agencies for community nursing, because about $80 \%$ of their patients are 60 years of age or above (National Association for Home Care, 1995). In addition, it is expected that society will become increasingly individualized, and that informal care will become less available. The number of people living alone will increase, especially among the elderly (Steering committee futurescenario's, 1992). With all these developments, delivering care in an efficient and effective way without diminishing its quality is becoming increasingly important. This is encouraged by government policy stressing a good price quality ratio (Ministry of Public Health, 1990). Therefore, an appropriate mix of staff is needed. McKenna's (1995) review of the literature demonstrates that the most effective and efficient way to provide health care lies in the employment of large numbers of qualified staff (instead of fewer qualified and more unqualified staff).

In addition to the increasing numbers of the elderly, epidemiological changes can be seen. The nature of health care problems is changing. Examples of these are: psychiatric and gerontological diseases, AIDS, cardiac diseases, several types of cancer, neurological disorders and chronic non specific lung diseases (CNSLD) (National Council for Health Care \& Foundation of the Dutch Economic Institute, 1988; Steering committee future-scenario's, 1987a. 1987b, 1990). These diseases change patient demands for care. Technological changes make other home treatments possible. Patients are discharged from hospitals quicker and sicker. Further, new types of 
(transmural) care are being introduced. As a result, nursing care at home will become more complicated (Taylor, 1985; Steering committee futurescenario's, 1992). Nurses with advanced nursing knowledge and skills are needed. Basic training is not always appropriate in meeting the increases and changes in demand on nursing. Care givers have therefore to be educated on the job in an effective and efficient way.

In line with these changes, agencies for community nursing have to carefully observe how best to use their staff to ensure high quality care. In this regard, two approaches have been adopted: differentiated practice and specialization. Differentiated practice is a personnel deployment model in which the roles of nurses are (re)defined in terms of education, experience and competence (Murphy \& DeBack, 1990). It seeks to ensure an appropriate mix of staff to deliver common community nursing care. Specialization is used to deliver care to patients with specific requirements for advanced nursing knowledge and skills. Consequently, some nurses have to be experts on specific parts of the broad area of community nursing. Differentiated practice is used to cope with the increased demand for care (caused by demographical changes) in particular; whereas specialization is used to face the changed demand for care (caused by epidemiological and technological changes).

\subsection{Community nursing}

In this dissertation community nursing is restricted to the care provided at home by professional agencies for community nursing and/or home nursing. It includes rehabilitative, supportive, promotive or preventive and technical nursing care. The emphasis is mainly on the nursing of sick people at home. Other possible community nursing activities are not included, e.g. preventive mother and child care, psychiatric care, midwifery, school health nursing and occupational nursing. Thus, community nursing in this dissertation is comparable with district nursing in the United Kingdom. Community nursing care is delivered by two types of nurse: the community nurse (first level, comparable with the registered nurse or the bachelor degree nurse) and the community nurse auxiliary (second level, comparable with the enrolled nurse or diploma / associate degree nurse).

Most agencies delivering community nursing are members of the National Association for Home Care. In 1992, in addition to 69 agencies for community nursing, 172 home help services joined this association. At that time there was cooperation between both types of agencies and a few agencies delivered both community nursing and home help service (called home care agencies). During the nineties a massive reorganization took place in home 
care. In 1996, the National Association for Home Care had the following members: 20 agencies for community nursing, 52 home help services and 47 home care organizations that delivered both community nursing and home help. In addition, in this period an increasing number of commercially-based private agencies were operating on the community nursing market.

\subsection{Differentiated practice}

In a number of industrial countries at least two types of nurse are employed by agencies for community nursing: first level nurses and second level nurses. This differentiation is based on a distinction in educational preparation (Verheij \& Kerkstra, 1992). Although both types of nurse have had a different type of training, this is often not expressed in nursing practice. Due to uncertainty about demarcation, both types of nurse carry out largely identical duties. For example, research in the Netherlands showed role ambiguity between first level and second level community nurses in $41 \%$ of the agencies for community nursing (Jansen \& Kerkstra, 1993) and Forsey et al. (1993) state that there is perhaps as much as an $80 \%$ overlap between nursing roles in general. As a result nurses are not always satisfied with their jobs, because of the lack of clarity about responsibilities and tasks (Werner Committee, 1991). As regards first level nurses, there is specific interest in what is their additional expertise when compared to second level nurses (Van der Peet, 1995; Smeets \& Van der Peet, 1995; Grypdonck, 1995; Veen \& Grotenhuis, 1995). Differentiated practice attempts to use the expertise of both types of nurse more effectively.

Differentiated practice is described as a division of labour or tasks within functions. Equivalent tasks are grouped at different levels as far as possible. Duties are ordered in terms of the 'cost of labour' criterion. This results in different job descriptions comprising activities which are rewarded equally (Keuning \& Eppink, 1990). With respect to nursing, the concept of differentiated practice is applied to utilize available nursing personnel more effectively. Based on the premise that individual practitioners, with different types of education, competence and experience should not be used interchangeably, differentiated practice seeks to ensure that the work of nurses is carried out by the most appropriate nurse in the most appropriate way (Boston, 1990). The basic distinctions between first and second level nurses centre on the complexity of decision-making, the range of responsibilities, and structure of situation and/or setting (Primm, 1986; Malloch et al., 1990). Although the 'complexity of nursing situations' is mentioned specifically in job descriptions this dimension has not extensively 
been studied and not generally been used in patient-assignment-systems (Soeken \& Prescott, 1991; Jansen \& Kerkstra, 1993).

Outcomes of differentiated practice have not been studied extensively except from the Sioux Valley Hospital / South Dakota Experience (Primm, 1987; Koerner et al., 1989; American Organization of Nurse Executives, 1990). This has been an important example for implementation of differentiated practice in nursing. Differentiated practice seems to have more positive effects (in terms of job characteristics and job satisfaction) on the job of first level nurses as compared with second level nurses (Koerner et al., 1989; Malloch et al., 1990; Hutchens, 1994). As regards the effects on quality of care, a reliable approach is lacking.

The existing results about implementation of differentiated practice concern hospital nursing only. As regards community nursing no information at all exists about the effects of differentiated practice on nurses and patient outcomes. Accordingly, more data are needed to implement differentiated practice in community nursing appropriately.

\subsection{Specialization}

Specialization is the second type of work(re)design studied in this dissertation. It concerns the way in which community nurses and community nurse auxiliaries specialize in order to meet the changed and complicated demands of community care. Several areas of specialization are possible because the populations served by community nurses and auxiliaries are so diverse (Riportella-Muller et al., 1991). Often clinical nurse specialists are employed to deliver specialized care. Examples of specialized patient categories are: patients who are HIV infected (Bond et al., 1991; Haste \& MacDonald, 1992; Layzell \& McCarthy, 1993), patients who need critical care by means of advanced technological equipment such as pumps for tube feeding and intravenous therapy, ventilators, suctioning machines, cardiac and respiratory monitors, terminally ill (e.g the Macmillan nurse) and diabetes mellitus (Bowyer, 1986; Kyne, 1986; Moyer, 1989; Bergen, 1991; Haste \& MacDonald, 1992; Nash, 1993; Griffiths \& Luker, 1994; Roe-Prioir, 1994).

Although the work of the clinical nurse specialist is seen to be worthwhile, Haste \& MacDonald (1992) and Griffiths \& Luker (1994) showed that community nurses wish to become more knowledgeable in specialist areas. These studies demonstrated that nurses are less satisfied with their job than clinical nurse specialists. Furthermore, it became obvious that nurses preferred to carry out the work of clinical nurse specialists themselves, but were prevented from doing so by heavy caseloads and lack of time. It seems 
that there is a solution to meet both the wishes of these nurses as well as the need for specialized knowledge. In the Netherlands so called 'areas-ofspecial-expertise' are circumscribed for community nurses and community nurse auxiliaries. Within one of these areas a community nurse (auxiliary) follows an education program/course of study, gets special on-the-job training, keeps up to date with all the new developments, and attends educational programs to stay abreast of trends and innovations on these issues. Subsequently, in her team and agency she can be consulted by her peers for knowledge or skills. In addition to this special expertise, this nurse performs the general tasks within community nursing (Ketelaars, 1996; Wiegers, 1992; Jansen \& Kerkstra, 1993; Van Haaren, 1994). In 1992, almost half of the Dutch agencies for community nursing had areas-of-special-expertise in use, and about one third intended to develop these areas for community nurses and community nurse auxiliaries (Jansen \& Kerkstra, 1993). Because this kind of specialization is relatively new the effects of implementation of areas-ofspecial-expertise are as yet largely unavailable.

\subsection{Job satisfaction, burnout and quality of care}

Implementation of differentiated practice and specialization (i.e. areas-ofspecial-expertise) are not without consequences; the job characteristics of community nurses and community nurse auxiliaries are changed. As a consequence it is supposed that this will affect job satisfaction and feelings of burnout. This is supported by several studies. Job characteristics that have positive effects on job satisfaction are for example autonomy, feedback, and low workload (Blegen, 1993; Irvine, 1995; De Jonge et al., 1995; De Jonge, 1995). Feelings of burnout increase for example as a result of high workload, increased role conflict, little challenge, little autonomy, and little support from peers and supervisors (Siefert et al., 1991; De Jonge et al., 1995; De Jonge, 1995). Thus, job satisfaction and burnout are suitable measures with which to study the effects of work-redesign (i.e. differentiated practice and specialization). In addition, work-redesign may not be at the cost of the quality of care, but rather improve the quality. In line with the central position that is given to patients in the health care system it is considered appropriate to listen to the patients' verdict.

\subsection{Aim of the study}

Changes in society and health care force agencies for community nursing to redesign nursing roles. The principles of differentiated practice and specialization are used. However, there are inadequate empirical data about 
the consequences of these types of work-redesign for care givers and patients. This study aims at investigating the effects of differentiated practice and specialization (i.e. areas-of-special-expertise) on job characteristics, job satisfaction, bumout and quality of care. In line with this several research questions will be answered in this dissertation.

In order to describe the Dutch situation with respect to differentiated practice and specialization in community nursing an inventory study was conducted which aimed to answer the following research question:

1. What are the differences in nursing performance between community nurses and community nurse auxiliaries in the Netherlands, and to what extent are their roles specialized?

The results of this inventory study are presented in the second chapter.

Subsequently, international literature was reviewed to collect more information about differentiated practice and specialization in community nursing. The results of this review are presented in chapter 3 and give an answer to the following research question:

2. What criteria are used to design an appropriate mix of staff, in what way is specialized nursing knowledge available, and how effective are these methods?

Based on the review of the literature, chapter 3 concludes in a research model to study the effects of differentiated practice and specialization (i.e. areas-of-special-expertise) in community nursing.

In order to be able to study these effects the initial situation is described in chapter 4 . In comparison with research question 1, the differences between community nurses and nurse auxiliaries are described more extensively here on the basis of the following research questions:

3. What are the differences in job characteristics, individual characteristics, job satisfaction and burnout between community nurses and community nurse auxiliaries?

4. What job characteristics and individual characteristics affect job satisfaction and bumout among community nurses and community nurse auxiliaries?

In order to study the effects of differentiated practice and specialization attention is paid to an essential aspect of differentiated practice: patientassignment. Chapter 5 describes the development and usage of an instrument that enables one to decide on the basis of the complexity of nursing care (= demand) what type of nurse is required (= supply). Data are presented to answer the following research questions: 
5. How can patient-assignment be based on the complexity of nursing care in a valid and reliable way?

6. To what extent is patient-assignment in community nursing congruent with the complexity of nursing care?

The effects of differentiated practice and specialization are described in chapters 6 and 7. The instrument for patient-assignment (described in chapter 5) and job profiles were used for differentiated practice. Areas-ofspecial-expertise were implemented for specialization. These areas were constructed mainly based on patient categories, where specific knowledge is needed for the caring, where a lot of treatment is possible or where many changes occur in a specific category. Chapter 6 pays attention to the caregivers' perspective by answering the following research question:

7. What are the effects of differentiated practice and specialization (i.e. areas-of-special-expertise) on job characteristics, job satisfaction and burnout among community nurses and community nurse auxiliaries?

Chapter 7 deals with the effects of differentiated practice and specialization on the quality of care, viewed from the patients' perspective. For this purpose an interview schedule was developed based on the principle that quality of care is the discrepancy between patients' expectations and patients' observations of several aspects of care. By using this interview sch?dule an attempt was made to answer the last research question:

8. What are the effects of differentiated practice and specialization (i.e. areas-of-special-expertise) in community nursing on the quality of care viewed from the perspective of the patient?

Finally, chapter 8 presents the general conclusions and discusses the findings. In this chapter the main results are summarized first. In addition, methodological and theoretical implications are mentioned and recommendations for future research are made.

It is noted that the chapters in this dissertation have been accepted or submitted for publication in several journals. This has the advantage that chapters can be read separately, but a certain amount of overlap is inevitable. 


\subsection{References}

American Organization of Nurse Executives (1990). Current issues and perspectives on differentiated practice. Chicago: American Hospital Association.

Bergen A. (1991). Nurses caring for the terminally ill in the community: a review of the literature. International Joumal of Nursing Studies 28(1), 89-101.

Blegen M.A. (1993). Nurses' job satisfaction: a meta-analysis of related variables. Nursing Research 42(1), 36-41.

Bond S., Rhodes T., Philips P., Setters J., Foy C. \& Bond J. (1991). Experience and preparation of community nursing staff for work associated with HIV infection and AIDS. Social Science \& Medicine 32(1), 71-76.

Boston C.M. (1990). Introduction. In: Current issues and perspectives on differentiated practice. (pp. 1-3). Chicago: American Organization of Nurse Executives.

Bowyer C.K. (1986). The complex care team: meeting the needs of high-technology nursing at home. Home Healthcare Nurse 4(1), 24-29.

Forsey L.M., Cleland V.S. \& Miller B. (1993). Job descriptions for differentiated nursing practice and differentiated pay. The Joumal of Nursing Administration 23(5) 33-40.

Griffiths J. \& Luker K. (1994). Community nurse attitudes to the clinical nurse specialist. Nursing Times 90(17), 39-42.

Grypdonck M. (1995). Verplegen met diepgang (In depth nursing). Tijdschrift voor ziekenverploging (7), 202-207.

Haaren E. van (1994). De expert: Carrière maken met de handen aan het bed (The expert: A career at the bedside). MGZ 22(4), 26-28.

Haste F.H. \& MacDonald L.D. (1992). The role of the specialist in community nursing: perceptions of specialist and district nurses. Intemational Joumal of Nursing Studies 29(1), $37-47$.

Hutchens G.C. (1994). Differentiated Interdisciplinary Practice. The Journal of Nursing Administration 24(6), 52-58.

Irvine D.M. \& Evans M.G. (1995). Job satisfaction and turnover among nurses: integrating research findings across studies. Nursing Research 44(4), 246-253.

Jansen P.G.M. \& Kerkstra A. (1993). Functiodifferentiatie binnen de thuiszorg. De functies van wijkverploegkundige, wijkverploegster en gezinsverzorgende nader omschreven (Differentiated practice and specialization in home care. The roles of the community nurse, community nurse auxiliary and home help in detail). Utrecht: NIVEL.

Jonge J. de (1995). Job autonomy, well-being and health. PhD-Thesis. Maastricht: Datawyse B.V. 1 Universitaire Pers.

Jonge J. de, Boumans N., Landeweerd A. \& Nijhuis F. (1995). De relatie tussen werk en werkbeleving (The relationship between job characteristics and psychological outcomes). Tijdschrift voor ziekenverpleging 105(7), 212-216.

Ketelaars C. (1996). Aftercare and specialised community nursing. Implications for patients with chronic obstructive pulmonary disease. PhD-thesis. Den Haag: Koninklijke Bibliotheek.

Keuning D. \& Eppink D.J. (1990). Management en Organisatie. Theorie en Toepassing (Management and organisations. Theory and Utilization). Leiden / Antwerpen: Stenfert Kroese Uitgevers.

Koerner J.E., Birch Bunkers L., Nelson B. \& Santema K. (1989). Implementing differentiated practice: the Sioux Valley hospital experience. The Joumal of Nursing Administration 19(2), 13-20.

Kooiker, S.E., C.S. (1992). Toekomstscenario's voor eerstelijnszorg en thuiszorg. Het gebruik van eerstelijnszorg en thuiszorg. Van trends uit het verleden naar ramingen voor de toekomst (Scenarios for the future in primary and home care. From trends in the past to estimates in the future). Modisch contact (12) 367-372. 
Kyne D. (1986). The specialist role. Senior Nurse 5(4), 17-18.

Layzell S. \& McCarthy M. (1993). Specialist or generic community nursing care for HIVIAIDS patients? Joumal of Advanced Nursing 18, 531-537.

Malloch K.M., Milton D.A. \& Jobes M.O. (1990). A model for differentiated nursing practice. Joumal of Nursing Administration 20(2), 20-26.

McKenna H.P. (1995). Nursing skill mix substitutions and quality of care: an exploration of assumptions from the research literature. Joumal of Advanced Nursing 21, 452-459.

Ministry of Public Health (1990). Heroverwogingsonderzoek 'Van Samenwerken tot samengaan' (A reconsideration 'From working together to being together'). Rijswijk: Ministry of Public Health.

Moyer A. (1989). Caring for a child with diabetes: the effect of specialist nurse care on parents' needs and concerns. Joumal of Aovanced Nursing 14, 536-545.

Murphy M. \& DeBack V. (1990). Myths and realities. In: Current issues and perspectives on differentiated practice (pp. 5-16). Chicago: American Organization of Nurse Executives.

Nash A. (1993). Reasons for referral to a palliative nursing team. Joumal of Advanced Nursing 18, 707-713.

National Association for Home Care (1995). Scenario-paper. Strategische koersbepaling van de thuiszorg-branche (Strategic market-report for home care). Bunnik: National Association Home Care.

National Council for Health Care and Foundation of the Dutch Economic Institute (1988). De arbeidsmarkt voor verpleegkundigen en ziekenverzorgenden (Labour market for nurses and nurse auxiliaries). Zoetermeer: National Council for Health Care.

Netherlands Central Bureau of Statistics (1995). Statistical Year-book. 's-Gravenhage: Sdu/uitgeverij, Netherlands Central Bureau of Statistics.

Peet R. van der (1995). De 'H' van HBO-V (The 'R' from RN). Tijdschrift voor Ziekenverpleging (4), 102-107

Primm P.L. (1986). Entry into practice; competency statements for BSNs and ADNs. Nursing Outlook 34(3), 135-137.

Primm P.L. (1987). Differentiated Practice for ADN- and BSN-Prepared Nurses. Joumal of Professional Nursing 4, 218-225.

Riportella-Muller R., Selby M.L., Salmon M.E., Quade D. \& Legault C. (1991). Specialty Roles in Community Health Nursing: A National Survey of Educational Needs. Public Health Nursing 8(2), 81-89.

Roe-Prior P., Watts R.J. \& Burke K. (1994). Critical care clinical nurse specialist in home health care: survey results. Clinical Nurse Specialist 8(1), 35-40.

Siefert K., Jayaratne S. \& Chess W.A. (1991). Job satisfaction, burnout, and turnover in health care social workers. Health and social work 16(3), 193-202.

Smeets H. \& Peet R. van der (1995), Verschil moet er zijn (There has to be difference). Tijdschrift voor Ziekenverpleging (1), 24-27.

Soeken K.L. \& Prescott P.A. (1991). Patient intensity for nursing index: the measurement model. Research in Nursing \& Health 14, 297-304.

Steering committee future-scenario's (1987a). Ouder worden in de toekomst. Tussenbalans (Getting older in the future). Rijswijk: Steering committee Future-scenario's Heathcare.

Steering committee future-scenario's (1987b). Kanker in Nederland. Deel I Scenario's over kanker 1985-2000 (Cancer in the Netherlands. Part I Scenario's about cancer 1985-2000). Rijswijk: Steering committee Future-scenario's Healthcare.

Steering committee future-scenario's (1990). Chronische ziekten in het jaar 2005. Deel 2 Scenanio's over CARA 1990-2005 (Chronic disesses in the year 2005. Part 2 Scenanio's about CNSLD 1990-2005). Houten/Antwerpen: Bohn Stafleu van Loghum.

Steering committee future-scenario's (1992). Toekomstscenario's voor eөrstelijnszorg en thuiszorg (Future-scenario's for extramural care and home care). Houten/Zaventem: Bohn Stafleu van Loghum. 
Taylor B. (1985). The effect of DRGs on home health care. New Jersey's experience suggests DRGs are increasing the need for home care for more acutely ill patients. Nursing Outjpok 33(6), 288-289.

Veen E. van der \& Grotenhuis R.B.M. (1995). De professional: lastig of nuttig voor een marktgerichte thuiszorgorganisatie? (The professional: exacting or useful for a maiket oriented home care organization?). MGZ 23(6), 26-29.

Verheij R.A. \& Kerkstra A. (1992). Intemational Comparative Study of Community Nursing. Avebury: Aldershot.

Werner Committee (1991). In hoger beroep (In further appeal). Rijswijk: Ministry of Public Health. Wiegers T.A. (1992). Evaluatie van modellen voor aans/uiting tussen intramurale specialistische en extramurale verpleegkundige cara-zorg voor kinderen (Assessment of models for the interface between intramural specialist CNSLD care and extramural CNSLD nursing care for children). Utrecht: NIVEL. 


\title{
2 DIFFERENTIATED PRACTICE AND SPECIALIZATION IN COMMUNITY NURSING:
}

\author{
a descriptive study in the Netherlands'
}

\subsection{Summary}

Nursing roles are described with respect to two principles on the basis of an inventory study in the Netherlands: differentiated practice and specialization. A total of 58 agencies for community nursing participated in this study (response $=84 \%$ ). In each of these agencies an expert was asked to answer questions by telephone. The results show that a distinction is made between two levels of nurses working in the community: community nurses and community nurse auxiliaries. This distinction is based on the complexity of care, the range of responsibilities, and a division between curative and preventive care (adult care versus mother and child health care). Assessment and the formulation of nursing diagnosis is reserved for nurses at the first level. Second level nurses are responsible for the other components of the nursing process. This study also showed that first level nurses regularly perform tasks not requiring their level of expertise. It has become obvious with regard to specialization that the generalist work for first level nurses is diminishing: they have to choose either (curative) adult care or (preventive) mother and child health care. Besides, first and second level nurses also have the opportunity of specializing in one or more patient categories. The aim of these so called 'areas-of-special-expertise' is to improve professionalism and patient care in community nursing.

Based on the results of this study the use of measures to guarantee that the mix of staff meets the demand of care is recommended. In line with this, special measures have to be taken to upgrade the tasks for community nurses. In this respect the use of areas-of-special-expertise and activities relating to co-ordination of care seem to be appropriate measures.

\subsection{Introduction}

Home health care is changing. The number of elderly people requiring home care is growing. Technological changes make it possible to provide more complex nursing care at home which demands special expertise from the

This chapter is an adapted version of the article Jansen P.G.M., Kerkstra A., Huijer AbuSaad H., Zee J. van der. Differentiated practice and specialization in community nursing: a descriptive study in the Netherlands. Accepted by Health \& Social Care in the Community. 
nurses. At the same time, governments demand efficient use of personnel and high quality care (Turton, 1984; Taylor, 1985; Kenyon et al., 1990; Gibbs et al., 1991). Agencies for community nursing are being forced to use a more business-like approach. In the Netherlands, the reimbursement system has changed from budget- and input-financing to product- and output-financing. Further, they have stimulated the agencies for community nursing and the home help agencies to co-operate and integrate in order to achieve greater efficiency (Ministry of Public Health, 1990). Between 1988 and 1992 the employment of registered nurses decreased, whereas more nurses with lesser qualifications were employed by the agencies (Netherlands Central Bureau of Statistics, 1990, 1994). Finally, nurses have been shown not to be satisfied with their job because of lack of clarity in responsibilities and tasks (Werner Committe, 1991). Because of these changes it has become increasingly important to ensure the efficient use of staff and the provision of high quality care. In this respect attention is paid to two principles of work design: differentiated practice or skill mix and specialization. Both principles are used to ensure that work is carried out by the most appropriate nurse in the most appropriate way. In this chapter, the concepts of differentiated practice and specialization in general, and the Dutch situation in particular will be described.

In the Netherlands, a distinction is made between two types of community nurse: community nurses and community nurse auxiliaries. In line with the Dutch 'Nursing Profile' (National Council for Health Care, 1988), 'complexity' of nursing care, and the range of 'responsibilities' are used as the distinguishing characteristics. The differences between the two types of community nurse in the Netherlands can be compared with that between the registered nurse and enrolled nurse in the United Kingdom (Verheij \& Kerkstra, 1992) or between nurses with a bachelor's and associate's degree in the United States (American Organization of Nurse Executives, 1990). Professionally, there is a difference between nurses and nurse auxiliaries; but, hierarchically, they are both managed by a head nurse.

\subsection{Review of the literature}

The concepts of differentiated practice and specialization will be described first in this section, and illustrated by examples from various industrialized countries. For a more detailed description of the literature concerning differentiated practice and specialization in community nursing, the reader is referred to chapter 3 . 


\subsubsection{Differentiated practice}

Differentiated practice refers to effective use of nursing personnel. It establishes the domain of nursing practice as broad, with multiple responsibilities of varying degree and complexity. Differentiated practice assumes that nurses with different levels of educational preparation, expertise, and background bring differing types of competence to the workplace. The differentiation of nursing roles is critical in ensuring high-quality care for patients and enhanced work satisfaction for nurses, and the efficient use of nursing and organizational resources. On the premise that individual practitioners with different types of education, competence, and experiences should not be used interchangeably, differentiated practice seeks to ensure that the work of nurses is carried out by the most appropriate nurse in the most appropriate way (Boston, 1990). Two different levels of nursing roles can be described. The basic distinction between the two roles centers on complexity of decision-making, range of responsibility, and the structure of the situation or setting. The nurse with a Bacherlor's degree (first level) provides direct care to patients and their families with complex interaction in nursing diagnosis from pre-admission to post-discharge in structured and unstructured settings and situations. The associate degree nurse (second level) provides direct care to patients and members of a family with common, well-defined nursing diagnosis for a specified work period in structured settings and situations (Primm, 1986, 1987; Malloch ot al., 1990). Differentiated practice can be compared with the skill mix issue in the United Kingdom: skills and experience of staff differ within different grades (Gibbs et al., 1991).

In most industrial countries, a differentiation is made between at least two levels of expertise in community nursing (Verheij \& Kerkstra, 1992). In Italy, Luxembourg, Portugal and Spain only first level nurses are employed in home care. This may be due to the fact that community nursing in these countries only started recently. In all countries, the nurses with second level qualifications are always more concerned with personal hygiene care and uncomplicated technical nursing (Hutten \& Kerkstra, 1995). It is problematic to give the ratios between the two levels of expertise because there are many divisions in tasks among many types of nurse in many countries. A great deal depends on the definition of first and second levels in each country. However, it is the case that in most countries only very small numbers of second level staff are available, and that Greece, Belgium and France have a higher number of second level nurses than the other countries. It has to be noted, however, that there is no difference in tasks between the first two levels in Belgium. Comparison with the figures from Verheij \& Kerkstra's (1992) study showed that the relative number of second level nurses in the Netherlands and the United Kingdom has increased over the last few years; while, in Belgium, the number of second level nurses has decreased in relative terms 
(Hutten \& Kerkstra, 1995). In the United Kingdom too there is a development which differs from all the other countries: training for enrolled nurses (second level of expertise) is being discontinued. Nursing schools will only produce registered nurses in the future. A new grade (support worker) will be introduced which will presumably be somewhere between an auxiliary and a state enrolled nurse (Verheij \& Kerkstra, 1992). Finally, the study of Verheij \& Kerkstra (1992) did not reveal many problems in respect of the division of labour among different types of nurse.

\subsubsection{Specialization}

Specialization relates to the way in which specialized knowledge is available in the community in order to meet the changed and complicated demands of home care. The international comparative study of Verheij \& Kerkstra (1992) showed two ways in which specialization could be implemented: by a division between (preventive) mother and child health care and (curative) adult care, or by a division of labour within curative adult care. The Netherlands, United Kingdom and Finland seem to be the countries in which the division between (preventive) mother and child health care and (curative) adultelderly care is an important issue. The study of Verheij \& Kerkstra (1992) revealed the Netherlands as the only country in which first level nurses delivered both mother and child health care, and adultelderly care (most second level nurses cared only for the adultelderly). In all other countries, most nurses were assigned to one of these categories of care and very often had different training as well. Experiences in the United Kingdom and Finland showed that the division between curative and preventive tasks could lead to difficulty. In the United Kingdom, care for the healthy elderly is considered a task for the health visitor and care for the elderly sick is considered a task for district nurses. Because both types of nurse work in separate teams, communication between them is often difficult. In Finland it was found that the specialist method of working involved a lot of travelling for nurses particularly in sparsely populated areas. This kind of specialization is consequently not always an efficient way of providing care (Verheij \& Kerkstra, 1992).

In most countries, clinical nurse specialists are employed for specialization within curative adult/elderly care. In many countries there is a limited number of specialist nurses whose main task is usually to advise colleagues. Most organizations in virtually all countries employ clinical nurse specialists or other professionals who are either working in the field or at a higher level in the organization. Sometimes the sources of specialist knowledge are supplemented by sources from outside the organization (Verheij \& Kerkstra, 1992). Although the work of clinical nurse specialists is seen to be worthwhile, the studies of Haste \& MacDonald (1992) and Griffiths \& Luker (1994) showed that some nurses would prefer to do the work of the specialists themselves, 
but that they are prevented from doing so by heavy caseloads and lack of time. In the Netherlands 'areas-of-special-expertise' are being developed in order to avoid discontent among nurses, and make specialized knowledge more readily available for nurses at the base. Community nurses and nurse auxiliaries can choose one of these areas and have the opportunity of developing special expertise for a specific category of patients. The nurse performs the general tasks within community nursing in addition to the specific activities regarding her area-of-special-expertise (Ketelaars, 1992; Wiegers, 1992; Jansen \& Kerkstra, 1993; Van Bragt, 1993; Van Haaren, 1994).

In order to get a more detailed overview of differentiated practice and specialization in the Dutch community nursing an inventory study was carried out to address two research questions:

1. What are the differences in nursing performance between community nurses and community nurse auxiliaries?

2. To what extent are the roles of community nurse and community nurse auxiliary specialized?

\subsection{Method}

Between November 1991 and January 1992 all the 69 agencies for community nursing in the Netherlands were approached to participate in a study to describe community nursing in respect of developments concerning differentiated practice and specialization among nurses and nurse auxiliaries. A total of 58 agencies responded positively (response $=84 \%$ ). In each of these agencies someone was appointed that could be considered as an expert concerning differentiated practice and specialization. In most agencies these persons hold the position of staff nurse or clinical nurse specialist.

These experts were asked to answer questions by telephone. An interview schedule was developed based on a review of organizational literature, and literature about differentiated practice and specialization in nursing. A group of experts discussed the schedule, and based on their assessment it was altered. Subsequently, the members of the agencies $(N=58)$ were interviewed. These semi-structured interviews lasted about $\mathbf{4 5}$ minutes. The main topics of the interview are presented in table 1. 
- distinguishing characteristics between community nurses and community nurse auxiliaries

- responsibility conceming different stages of the nursing process

- clarity of division in tasks in job descriptions and practice

- the use of criteria for patient-assignment
- kind of specialization

* reasons for specialization

" tasks within specialization

These topics were chosen to get a picture of the content of differentiated practice and specialization in community nursing. The results of the interviews were summarized using the statistical program SPSS/PC+. Besides answering questions by telephone the respondents were also asked to send relevant policy documents. About 70 documents were received that could be classified in five categories: general (structure of the agency), differentiated practice, specialization, co-operation between community nursing and home help and others (e.g. nursing assessment and co-ordination of care). These documents gave insight in mission-statements and definitions of concepts (i.e. differentiated practice and specialization). Using these documents, the results of the telephone interview could be further described.

\subsection{Results}

\subsubsection{Differentiated practice}

Community nurses and community nurse auxiliaries were employed in all agencies. In two agencies no distinction was made between these two types of nurse. In these agencies community nurses and nurse auxiliaries performed the same tasks and had the same responsibilities. In the other 56 agencies, a distinction was made by means of several characteristics. The range of responsibility and the complexity of nursing care were in $95 \%$ of the agencies seen as the two most important characteristics to differentiate between community nurses and community nurse auxiliaries. In respect of complexity, community nurses deliver care in highly complex situations; whereas nurse auxiliaries are deployed in less complex situations. Moreover, in most agencies (89\%) nurse auxiliaries do not deliver preventive mother and child health care, but only curative adult/elderly care; neither do they operate in all stages of the nursing process in most agencies (86\%).

To get a more detailed picture of the difference in responsibility the respondents were asked to indicate who was responsible for the carrying out of the five stages of the nursing process (assessment, diagnosis, planning, implementation and evaluation), and for the continuity and co-ordination of 
care. The results are presented in figure 1 for the 53 agencies who made a distinction based on responsibility. It was assumed that community nurses could be responsible for all the stages of the nursing process, as well as the continuity and co-ordination of care. Accordingly, a distinction is made between the areas for which only community nurses are responsible, and the areas for which both nurses and nurse auxiliaries are responsible.

Figure 1 Differences in responsibilities between community nurses and community nurse auxiliaries in agencies for community nursing, in percentages ( $n=53$ )

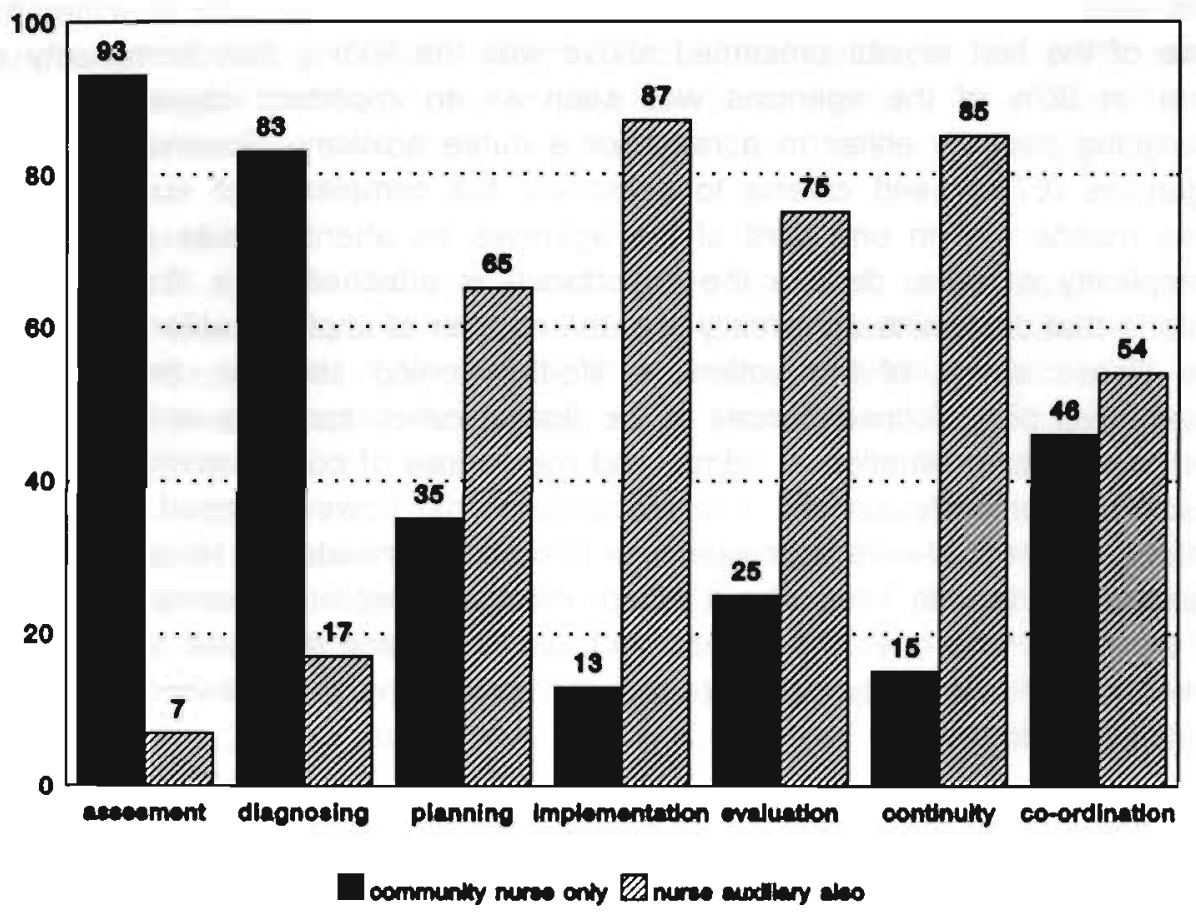

The differences are particularly obvious in the assessment (gathering data) and the formulation of nursing diagnosis. In $93 \%$ and $83 \%$ of the agencies respectively, the community nurse is solely responsible for this. In most agencies the community nurse auxiliary is responsible for the other components of the nursing process as regards the patients in her own caseload. Furthermore, in most agencies, she is responsible for the continuity of care (e.g. during absenteeism) and in half of the agencies for the coordination of care. Co-ordination has been described as the guarantee of coherence of care delivered by nurses, home helps, general practitioners and social workers.

In line with the difference in responsibilities there is a difference in accountability. The community nurse auxiliary is accountable for their own 
practice, whereas community nurses are accountable for own practice and the nursing care performed by nurse auxiliaries. This means that the care delivered by nurse auxiliaries is regularly discussed and evaluated by the nurse and nurse auxiliary together.

In $84 \%$ of the agencies, profiles were present in which the differences between community nurses and community nurse auxiliaries were described. In spite of the presence of these profiles, there was a lack of understanding concerning the differences between the two types of nurse in $41 \%$ of the agencies.

One of the first results presented above was the finding that 'complexity of care' in $95 \%$ of the agencies was seen as an important characteristic in assigning patients either to a nurse or a nurse auxiliary. However, only 39 agencies $(67 \%)$ used criteria to determine the complexity of nursing care. This means that in one third of the agencies no attention was paid to the complexity of care, despite the importance is attached to it. Examples of criteria that determine complexity are: the number of unpredictable changes in the illness status of the patient, a life-threatening situation, the patient's awareness of the consequences of the illness status, spouse's ability to cope with the nursing-situation at home, and the degree of co-operation with other disciplines or professionals. The respondents did however report that these criteria were not always appropriate, or unclear and needed to be revised.

Besides the criteria cited above others mentioned were: personal judgement of the nurse who does the assessment, workload, and the need for activities reserved for community nurses (e.g. technical nursing like catheterization and intravenous infusion).

All these criteria are meant to ensure that the work of nurses is carried out by the most appropriate nurse in the most appropriate way. However, this is not always the case as is illustrated by the answers on the following question: "Do nurses and nurse auxiliaries regularly perform tasks above or below their level of training and experience?" The response to this question used the respondent's perception of job descriptions (i.e. the Dutch Nursing Profile) as the point of reference.

Most (95\%) of the respondents stated that community nurses regularly perform tasks below their level of expertise. In one third $(35 \%)$ of the agencies community nurse auxiliaries regularly perform tasks that require the level of a community nurse. In almost half $(48 \%)$ of the agencies the respondents think that nurse auxiliaries regularly perform tasks below their level of expertise, i.e. tasks that could be performed by certified home helps. 
Although this study focuses on community nursing, the experts of the agencies were also questioned about the 'boundary area' between community nursing and home help services. In line with the changes stated in the introduction of this chapter most of the agencies for community nursing cooperated with home help services: almost $60 \%$ of the agencies co-operated on management-level (between managers) and $90 \%$ on operational-level (i.e. co-operation between nurses and home helps). In almost half of the agencies for community nursing job descriptions existed describing the difference between the domain of community nursing and the domain of home help. This difference is described as follows in most agencies: community nurses and community nurse auxiliaries deliver care concentrated on a health care problem whereas certified home helps focus on problems in housekeeping or situations where informal carers can no longer provide the care necessary.

\subsubsection{Specialization}

Two types of specialization were used in the agencies: at an organizational level, specialization between the 'mother and child health care' division and the 'adult/elderly care' division, and, at an individual level, specialization by means of 'areas-of-special-expertise'. The presence of the two types of specialization in 1992 is presented in figure 2.

To understand the results in figure 2 it is essential to note that community nurses have received training in both adultelderly care, and mother and child health care. Nurse auxiliaries are trained to care for the adult/elderly only. Thus, for community nurses it is exceptional for them to work within one division only. On the other hand, it is exceptional for community nurse auxiliaries to deliver care within both divisions.

Looking at the community nurses at first, figure 2 shows that in the beginning of 1992 nurses were employed using the allround method in most agencies, i.e. the same nurse takes care of the (preventive) child health care as well as the (curative) adult/elderly care (i.e. in accordance with their training). These results also show that in one third of the agencies nurses work in either of the two divisions. As regards the community nurse auxiliaries, in the majority of the agencies, they only take care of elderly people (i.e. in accordance with their training). 
Figure 2 Different types of specialization in agencies for community nursing, in percentages $(n=58)$

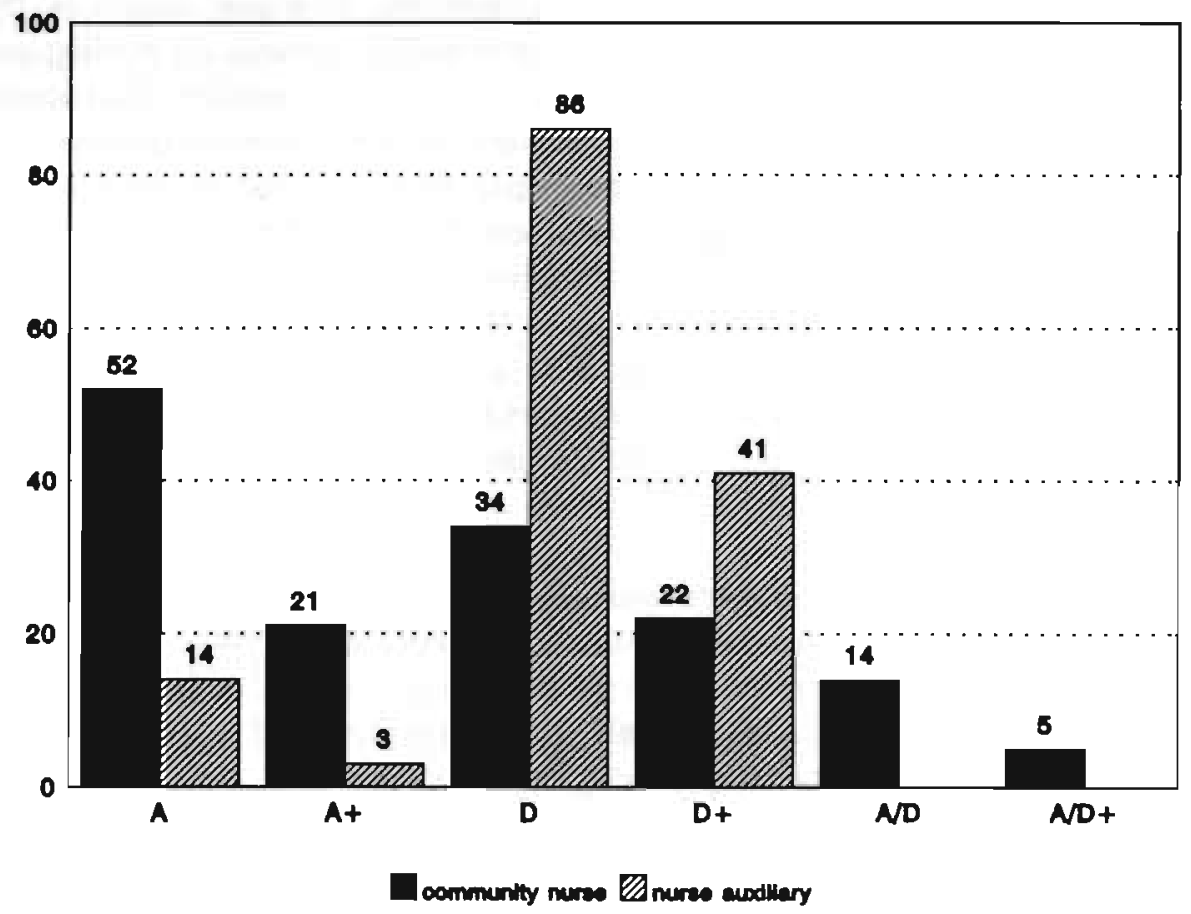

Legend:

A: Allround

At: Allround with areas-of-special-expertise

$\mathrm{D}$ : Division between 'mother and child health care' and 'adult care'

D+: Division 'adult care' with areas-of-special-expertise

AVD: Allround and two divisions

AVD+: Allround and two divisions with areas-of-special-expertise

The percentages of $A, D$ and $A / D$ together make $100 \%$

( $A+$ is a part of $A, D+$ is a part of $D$ and $A D+$ is a part of $A D D$ ).

In addition to this kind of specialization, nurses and nurse auxiliaries specialize in areas-of-special-expertise. In $48 \%(=21 \%+22 \%+5 \%)$ of the agencies community nurses had these specialties and in $44 \%(=3 \%+41 \%)$ of the agencies nurse auxiliaries also had them. Several reasons mentioned for specialization are presented in table 2 . 


\begin{tabular}{lcc}
\hline & $\begin{array}{c}\text { Division between adult care } \\
\text { and mother and child heatth care }\end{array}$ & $\begin{array}{c}\text { Areas-of-special- } \\
\text { expertise }\end{array}$ \\
\hline maintains and improve expertise & 93 & 100 \\
efficient use of personnel & 87 & 63 \\
changing demand for care & 77 & 76 \\
increased complexity of care & 77 & 86 \\
increased amount of care & 72 & 41 \\
improving job satisfaction & 49 & 76 \\
improving attraction of nursing & 36 & 61 \\
\hline
\end{tabular}

Three reasons have equal standing for both types of specialization: i.e. maintaining or improving the expertise of the nurses, coping with the changing demand and increased complexity of care. The results also show that the separation into divisions seems to be more often efficiency-based; whereas the areas-of-special-expertise are more often designed to improve the professionalism of community nursing (improving job satisfaction and attractiveness).

The areas-of-special-expertise are based on patient categories in most agencies. These areas are created if specific care is requested in a.idition to basic care. Specific care relates to nursing care that does not haviz to be given frequently, and patient categories in which there are a lot of developments. Examples of these areas are: diabetes mellitus, patients with AIDS, chronic non specific lung diseases (CNSLD), dementia, rheumatism, or incontinence. In most agencies, nurse auxiliaries can only choose psychogeriatrics (dementia) and incontinence. The reason for this is, that the other areas require expertise at the level of a nurse, as these situations are often more complex. In these areas the nurse auxiliary keeps all the literature up to date $(81 \%)$, attends educational programs $(81 \%)$, stays abreast of trends and innovations $(79 \%)$, and attends conferences $(78 \%)$. Subsequently, she can be consulted by peers in her team and agency for knowledge or skills $(76 \%)$. In addition to this special expertise, the nurse performs the general duties within community nursing. In the future, in most agencies the community nurse auxiliary will specialize in both fields: $92 \%$ of the agencies wants to make a division between 'mother and child health care' and 'adult/elderly care'; and, as regards the areas-of-special-expertise, $84 \%$ of the agencies will develop them for community nurses and $72 \%$ for community nurse auxiliaries. 


\subsection{Discussion}

This study has shown that there are clear differences between community nurses and community nurse auxiliaries with respect to the assessment and the formulation of nursing diagnoses. These activities are restricted to community nurses. The complexity of nursing care is seen by most respondents as an important distinguishing characteristic; but, in practice, there are not always appropriate criteria in determining the degree of complexity. This study has also shown that the demand for community nursing is not always appropriate to the level of training community nurses have received. In almost all agencies community nurses regularly perform tasks below their level of expertise and experience. An important reason for this is probably inappropriate staffing. There are more community nurses employed than nurse auxiliaries, whereas in many nursing situations, basic care is required, which can be delivered by community nurse auxiliaries. We also see that nurse auxiliaries often perform tasks that could be done by certified home helps. The main reasons for this were the long waiting lists that exist for home help services, the shortage of home helps, and a lack of clarity about the difference between the domain of home help and the domain of community nursing. Furthermore, variety in the work of first level nurses is diminishing: the all round or generic concept is being abandoned and nurses have to choose either mother and child health care or adult/elderly care. In addition to these developments in the content of community nursing, this study shows an increased interest in giving nurses and nurse auxiliaries the opportunity to specialize in a specific patient category. Agencies are trying to improve the professionalism of community nursing by means of areas-ofspecial-expertise.

Some recommendations for differentiated practice and specialization in community nursing can be made on the basis of these results. In the first place, having a mix of staff that meets the demand for care is important. The ratio between nurses and nurse auxiliaries can be determined by the use of valid criteria of complexity. The expectation is that this will have consequences for the present ratio of 3 nurses : 1 nurse auxiliary in favour of the number of community nurse auxiliaries.

In addition, more co-operation and integration of home help services and agencies for community nursing is supposed to promotes clarity in demarcation and harmonization of duties between both types of services. As a result it will be easier to assign an appropriate care-giver to the patient when nursing- or home-help-situations are changing.

Because community nurse's expertise seems not to be used adequately, special measures have to be taken to upgrade the tasks for community nurses. Nurses have to be assigned more often to complex nursing situations, 
and have to concentrate on activities relating to assessment, diagnosis and co-ordination.

Finally, the use of areas-of-special-expertise seems to be an appropriate measure to upgrade both the roles of nurses and nurse auxiliaries. In addition to the employment of clinical nurse specialists, the introduction of these areas can guarantee specialized knowledge in community nursing. An important advantage in these areas is the assurance of quality employment for nurses. These areas will also favour the patient, because a structural improvement of expertise of the nurse (by means of areas-of-special-expertise) is suggested to lead to a good quality of care. In addition, to save costs patients have to be discharged more quickly from hospitals and this leads to more complex nursing situations at home. To be able to cope with these situations caregivers have to be equipped properly. Areas-of-special-expertise seem to be an appropriate means for this. 


\subsection{References}

American Organization of Nurse Executives (1990). Current issues and perspectives on differentiated practice. Chicago: American Hospital Association.

Boston C.M. (1990). Introduction. In: Current issues and perspectives on differentiated practice (pp. 1-3). Chicago: American Organization of Nurse Executives.

Bragt M.J.A.B. van (1993). Het gedifferentieerd en allround werken binnen de wijkverpleging. Een onderzoek bij Kruiswerk West-Brabent en Stichting Interkruis Noord-Kennemertand (Specialization and non-spocialization in community nursing. A study carried out at Kruiswerk West-Brabant and Stichting Interkruis Noord-Kennemerland). Maastricht: Rijksuniversiteit Limburg.

Gibbs I., McCaughan D. \& Griffiths M. (1991). Skill mix in nursing: a selective review of the literature. Joumal of Advanced Nursing (16), 242-249.

Griffiths J. \& Luker K. (1994). Community nurse attitudes to the clinical nurse specialist. Nursing Times 90(17), 39-42.

Haaren E. van (1994). De expert: Carrière maken met de handen aan het bed (The expert: A career at the bedside). MGZ 22(4), 26-28.

Haste F.H. \& MacDonald L.D. (1992). The role of the specialist in community nursing: perceptions of specialist and district nurses. Intemational Joumal of Nursing Studies, 29(1), $37-47$

Hutten J.B.F. \& Kerkstra A. (1995). Organization and Financing of Home Care in Europe. Utrecht: NIVEL.

Kenyon V., Smith E., Hefty L.V., Bell M.L., McNeil J. \& Martaus T. (1990). Clinical Competencies for Community Health Nursing. Public Health Nursing 7(1), 33-39.

Jansen P.G.M. \& Kerkstra A. (1993). Functiedifferentiatie binnen de thuiszorg. De functies van wijkverplogkundige, wijkverpleegster en gezinsverzorgende nader omschreven (Differentiated practice and specialization in home care. The roles of the community nurse, community nurse auxiliary and home help in detail). Utrecht: NIVEL.

Ketelaars C. (1992). Goede nazorg door gedifferentieerde wijkverpleegkundigen (Good follow-up care by community nurses with an area-of-special-expertise). MGZ 20(5), 32-34

Malloch K.M., Mitton D.A. \& Jobes M.O. (1990). A model for differentiated nursing practice. Journal of Nursing Administration 20(2), 20-26.

Ministry of Public Health (1990). Heroverwogingsonderzoek 'Van Samenwerken tot samengaan' (A reconsideration 'From working together to being together'). Rijswijk: Ministry of Public Health.

National Council for Health Care (1988). Verpleegkundig beroepsprofiel (Nursing Profile). Zoetermeer: National Council for Health Care.

Netherlands Central Bureau of Statistics (1990 and 1994). Vademecum of Health Statistics of The Netherlands. Voorburg/Heerlen: Netherlands Central Bureau of Statistics.

Primm P.L. (1986). Entry into practice: competency statements for BSNs and ADNs. Nursing Outhook 34(3), 135-137.

Primm P.L. (1987). Differentiated Practice for ADN- and BSN-Prepared Nurses. Joumal of Professional Nursing 4, 218-225.

Taylor B. (1985). The effect of DRGs on home health care. New Jersey's experience suggests DRGs are increasing the need for home care for more acutely ill patients. Nursing Outlook (6), 288-289.

Turton P. (1984). Nurses working in the community. Nursing Times (5), 40-42.

Verheij R.A. \& Kerkstra A. (1992). Intemational Comparative Study of Community Nursing. Avebury: Aldershot.

Werner Committee (1991). In hoger beroep (In further appeal). Rijswijk: Ministry of Public Health. 
Wiegers T.A. (1992). Evaluatio van modellen voor aansluiting tussen intramurale specialistische en extramurale verpleegkundige cara-zorg voor kinderen (Assessment of models for the interface between intramural specialist CNSLD care and extramural CNSLD nursing care for children). Utrecht: NIVEL. 
a review of the literature'

\subsection{Summary}

In most agencies for community nursing at least two types of nurse are employed. To ensure efficient use of personnel and high quality of nursing care, the principles of differentiated practice and specialization are used. These types of work redesign is suggested to have consequences for nurses and their work. We made a review of the literature to see how these principles are used and their effects on job satisfaction, burnout and quality of care. This review provides several views and descriptions of nursing activities, but it also shows that there is a paucity of quantitative data about the effects of differentiated practice and specialization in community nursing. To study these effects more systematically, a research model is presented. This model makes it possible to describe the changes in job characteristics caused by differentiated practice and specialization. Secondly, it allows the effects on job satisfaction, burnout and quality of care to be studied.

\subsection{Introduction}

This study focuses on labour division in community nursing. Because there is a difference among countries in the definition of 'community nursing', firstly we explain what is meant by community nursing in this study. Community nursing is restricted to the care provided at home by professional home nursing agencies. It includes rehabilitative, supportive, promotive or preventive and technical nursing care. The emphasis is mainly on the nursing of sick people at home. Other possible community nursing activities are not included, e.g. preventive mother and child care, psychiatric care, midwifery, school health nursing and occupational nursing. This means that for instance in the United Kingdom only district nursing is considered.

Based on educational preparation in several countries a differentiation is made between first level nurses and second level nurses (Verheij \& Kerkstra, 1992). As described in chapter 2 the different type of training is often not expressed in nursing practice. Both types of nurse perform largely identical activities. According to Forsey et al. (1993) this is also the case in the United

This chapter is an adapted version of the article Jansen P.G.M., Kerkstra A., Huijer AbuSaad H., Zee J. van der. Accepted by Joumal of Advanced Nursing. 
States of America. They state that there is perhaps as much as an $80 \%$ overlap between nursing roles in general. In addition to this, agencies for home health care are now also faced with a lot of changes. The number of the elderly requiring home care is growing. Technological change makes it possible to provide more complex nursing care at home. This requires special expertise from the nurses to be able to deliver high quality care. On the other hand, governments want an efficient use of presenile in a cost-effective way (Turton, 1984; Taylor, 1985; Kenyon et al., 1990; Gibbs et al., 1991). Basic training is not always appropriate in meeting the increases and changes in demand on community nursing.

In these circumstances, agencies delivering community nursing care are forced to redesign nursing roles. To ensure high quality of care and efficiency, two principles seem to be appropriate: differentiated practice and specialization. Differentiated practice is a personnel deployment model in which the roles of nurses are (re)defined based on education, experience and competence (Murphy \& DeBack, 1990). Specialization concerns the way in which specialized knowledge is available in the community in order to meet the changed and complicated demands of home care.

\subsubsection{Theoretical context}

Differentiated practice and specialization are not issues restricted to nursing alone. In order to understand these principles from an organizational perspective, first a central aspect of the division of labour is described: job specialization. This description is based on Mintzberg's Structure in Fives. Designing effective organisations (1983). Organizations divide their labour (i.e. specialize) to increase productivity. The reasons for increasing productivity are: the improved dexterity of the worker from specialization in one job, the saving of time lost in switching jobs, and the development of new methods and machines that derive from specialization (Mintzberg, 1983). These reasons are comparable with community nursing, where labour is divided to ensure high quality of care and efficient use of personnel.

Jobs can be specialized in two dimensions. The first is 'breadth' or 'scope': how many different tasks are there in each job and how broad or narrow is each of these tasks (horizontal job specialization deals with parallel activities). The second dimension of specialization relates to 'depth', to the control over the work. This vertical specialization separates the performance of the work from its administration (Mintzberg, 1983). By way of comparison in community nursing, roles are specialized vertically by 'differentiated practice' and horizontally by 'specialization'. In other words, as regards differentiated practice, equivalent jobs are grouped at different levels, based on the cost of labour criterion. This results in different job descriptions containing activities 
which are equally rewarded. The emphasis in specialization is on the quality of activities and the final result (Keuning \& Eppink, 1990).

When nursing roles are redesigned it is very important not to lose sight of professional values. In line with this Hackman \& Oldham $(1975,1976,1980)$ constructed the Job Characteristics Model, specifically meant for work redesign (figure 1 ).

Figure 1 Job Characteristics Model

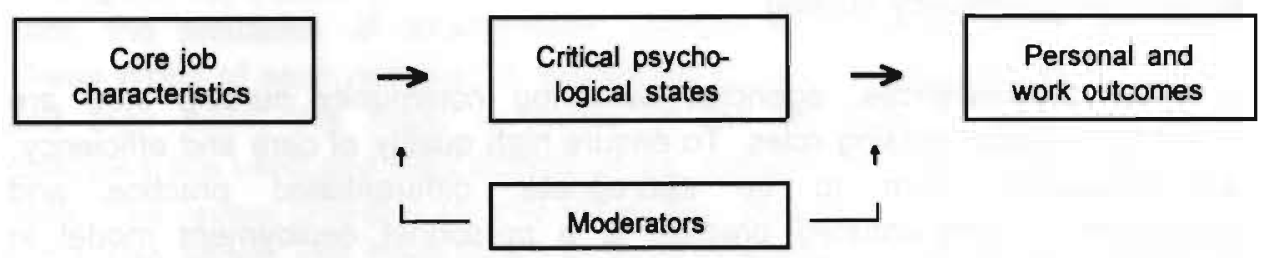

Source: Hackman \& Oldham, 1975, 1976, 1980

This model posits the achievement of positive personal and work-outcomes, when three critical psychological states are present for a given employee (experienced meaningfulness of the work, experienced responsibility for outcomes of the work, and knowledge of the actual results of the work activities). These critical psychological states are created by the presence of five core job characteristics: skill variety, task identity, task significance, autonomy and feedback (Hackman \& Oldham, 1975, 1976, 1980). However, as the model as a whole was not validated in research, an altered version was used to describe hospital nursing practice (Landeweerd \& Boumans, 1988; Boumans, 1990). The intermediate role of the critical psychological states (Algera et al., 1986), and the effects of the moderators (Roberts \& Glick, 1981; Boumans, 1990) were not often validated. Instead Boumans (1990) found direct relations between job- and individual characteristics and the outcome variables, e.g. job satisfaction, health complaints and quality of care. Effects on depression, psychological- and psycho-somatic complaints were also found (Algera, 1983; Broadbent, 1985). These complaints can be grouped under the concept 'burnout': 'a syndrome of emotional exhaustion, depersonalisation and reduced personal accomplishment that can occur among individuals who do people work of some kind' (Maslach \& Jackson, 1986).

Because of the link with work redesign, the Job Characteristics Model and the alterations made in other studies, will be used as frame of reference for a review of the literature concerning differentiated practice and specialization. In line with this model the review of the literature seeks to address the following questions: 
1. What models are used to differentiate between nursing roles?

2. What models are used to make specialized knowledge available in community nursing?

3. What are the effects of differentiated practice and specialization on job characteristics, job satisfaction, burnout and quality of care?

4. What aspects should be encompassed in a research model to evaluate the effects of differentiated practice and specialization in community nursing?

\subsection{Method}

In order to obtain the international literature, searches were carried out in three computer databases: Medline (1986-1994), Nursing and Allied Health Literature (only between 1992-1994, because of overlap with Medline) and the Catalogue of the Netherlands Institute of Primary Health Care (NIVEL) (up to and including 1995). The key words used in these searches are (in alphabetical order): burnout, clinical ladder, clinical nurse specialist, differentiated practice, job satisfaction, level of expertise, nursing roles, quality of care, skill mix and specialization. Because the literature found was mainly applied to nursing in the United States of America, the United Kinndom and the Netherlands, the review was restricted to these countries. Int rrmation about both hospital nursing and community nursing was reviewed to be able to describe differentiated practice. Hospital nursing was included because in the USA important examples were found in this area. With respect to specialization, the review concentrates on community nursing alone, since enough relevant examples were found. The review does not claim to be exhaustive; but representative.

\subsection{Results}

\subsubsection{Differentiated practice: the concept and models}

To differentiate between nursing roles different models are used in the United States of America, the Netherlands and the United Kingdom. Table 1 shows an overview of the models used, the types of nurse concerned and the means used for differentiating nursing roles. This table will be illustrated by means of a description of the literature reviewed. 


\begin{tabular}{|c|c|c|c|}
\hline Models & $\begin{array}{l}\text { Types of nurse } \\
\text { concerned }\end{array}$ & $\begin{array}{l}\text { Years of } \\
\text { education }\end{array}$ & $\begin{array}{l}\text { Means for } \\
\text { differentiating }\end{array}$ \\
\hline $\begin{array}{l}\text { United States of America: } \\
\text { differentiated practice } \\
\text { " clinical ladders }\end{array}$ & $\begin{array}{l}\text { baccalaureate nurse } \\
\text { diploma nurse } \\
\text { associate degree nurse } \\
\text { auxiliary }\end{array}$ & $\begin{array}{l}4 \text { years } \\
3 \text { years } \\
2 \text { years } \\
0 \text { years }\end{array}$ & $\begin{array}{l}\text { * job descriptions } \\
\text { - factoring }\end{array}$ \\
\hline $\begin{array}{l}\text { The Netherlands: } \\
\text { - differentiation based on } \\
\text { responsibility and } \\
\text { complexity of care }\end{array}$ & $\begin{array}{l}\text { registered nurse } \\
\text { nurse auxiliary }\end{array}$ & $\begin{array}{l}4-5 \frac{1}{2} \text { years } \\
21 / 2-3 \text { years }\end{array}$ & $\begin{array}{l}\text { * job descriptions } \\
\text { measures for } \\
\text { complexity of care }\end{array}$ \\
\hline $\begin{array}{l}\text { The United Kingdom: } \\
\text { " skill mix }\end{array}$ & $\begin{array}{l}\text { registered nurse } \\
\text { enrolled nurse } \\
\text { auxiliary }\end{array}$ & $\begin{array}{l}3 \text { years } \\
2 \text { years } \\
0 \text { years }\end{array}$ & $\begin{array}{l}\text { " patient-dependency } \\
\text { measures }\end{array}$ \\
\hline
\end{tabular}

In 1965, the US American Nurses' Association proposed two levels of education, a baccalaureate degree for the professional nurse and an associate degree for the technical nurse (Hickey et al., 1991). This proposal was the foundation for the model of differentiated practice used to differentiate between two nursing roles in hospitals based on education, experience and competence (Primm, 1986, 1987, 1988, 1990; Koerner et al., 1989; Koerner, 1990; American Organization of Nurse Executives, 1990; Malloch et al., 1990; McClure, 1991; Hickey et al., 1991; Forsey et al., 1993). In the USA all registered nurses hold the same license to practice nursing regardless of their educational or experiential background (Murphy \& DeBack, 1990). To utilize available nursing personnel more effectively, differentiated practice is applied. Based on the premise that individual practitioners with different types of education, competence, and experience should not be used interchangeably, differentiated practice seeks to ensure that the work of nurses is carried out by the most appropriate nurse in the most appropriate way (Boston, 1990).

The Sioux Valley Hospital / South Dakota Experience (Primm, 1987; Koerner et al., 1989; American Organization of Nurse Executives, 1990) has been an important example for implementation of differentiated practice in nursing. This project (1982 to 1987) used a group process approach to achieve representative regional consensus on competency-based statements of practice expectation for diploma/associate- and baccalaureate-prepared nurses. The term 'competency-based' referred to identification of role behaviours by observation of the practice of 'experts' in the role. In other words, the descriptions of practice are descriptions of 'competent' 
practitioners. Based on these competencies two nursing roles were defined (table 2).

Table 2 Roles of the Associate Degree Nurse and the Baccalaureate Degree Nurse

\section{Role of the Associate Degree Nurse (ADN)}

The ADN is a licensed registered nurse who provides direct care that is based on the nursing process and focused on individual clients who have common, welldefined nursing diagnoses. Consideration is given to the client's relationship within the family. The ADN functions in a structured health care setting that is a geographical or situational environment where the policies, procedures, and protocols for provision of health care are established. In the structured setting there is recourse to assistance and support from the full range of nursing expertise.

The ADN uses basic communication skills with focal clients and coordinates with other health team members to meet focal clients' needs. The ADN recognizes the individual's need for information and modifies a standard teaching plan. The ADN recognizes that nursing research influences nursing practice and assists in standardized data collection.

The ADN organizes for focal clients those aspects of care for which s/he is responsible. The ADN maintains

accountability for own practice and for aspects of nursing care s/he delegates to peers, licensed practical nurses, and ancillary nursing personnel. Within a specified work period, the ADN plans and implements nursing care that is consistent with the overall admission to post-discharge plan. The ADN practices within accepted ethical and legal parameters of nursing.
Role of the Baccalaureate Degree Nurse (BSN)

The BSN is a licensed registered nurse who provides direct care that is based on the nursing process and focused on clients with complex interaction of nursing diagnoses. Clients include individuals, families, groups, aggregates, and communities in structured and unstructured health care settings. The unstructured setting is a geographical or a situational environment that may not have established policies, procedures, and protocols and has the potential for variations requiring independent nursing decisions.

The BSN uses complex communication skills with focal clients. The BSN collaborates with other health team members and assumes an accountable role in change. The BSN assesses the need for information and designs comprehensive leaching plans individualized for th ? focal client. The BSN collaborates with nu'se researchers and incorporates research findings into nursing practice.

The BSN manages comprehensive nursing care for focal clients. The BSN maintains accountability for own practice and for aspects of nursing care delegated to other nursing personnel consistent with their levels of education and expertise. The BSN plans for nursing care based on identified needs of the focal client from admission to post-discharge. The BSN practices within accepted ethical and legal parameters of nursing.

Source: Primm (1987), American Organization of Nurse Executives (1990)

The basic distinctions between the two roles in respect of differentiated practice centre on complexity of decision-making, range of responsibilities, and structure of situation and/or setting. The baccalaureate nurse provides direct care to patients and their families with complex interactions of nursing diagnoses from pre-admission to post-discharge in structured and unstructured settings and situations. The associate nurse provides direct care to patients and members of a family with common, well-defined nursing 
diagnoses for a specified work period in structured settings and situations (Primm, 1986; Malloch et al., 1990).

Although 'complexity' is mentioned specifically in the job descriptions this dimension has not generally been included in American patient classification systems (see e.g. Strickland \& Neely, 1995) except to the degree that more complex care often is positively related to time. However, the findings of the use of the Patient Intensity for Nursing Index (PINI) suggest that complexity of patient care needs are as, or more, important to the consumption of nursing resources than are patients' dependency needs (Soeken \& Prescott, 1991). In only a few articles was attention paid to the operationalization of the concept of 'complexity'. According to Corcoran (1986), complexity is determined by the number of problems presented by the patient, the interrelation of the problems, and the extent to which protocols could be applied. Verran \& Reid (1987) found that complexity was affected by the number of analyses that had to be performed, the variability of clients presenting to a clinic and the knowledge of a client (i.e. nurse's understanding). Nursing care is considered complex when the degree of routineness, uniformity and predictability is low and special knowledge is necessary to deliver care. The critical determinant of complexity is the extent to which knowledge is required to effectively apply interventions in the delivery of nursing service. In addition, complexity involves not only the frequency of task performance but also knowing whether the procedures for its accomplishment are well-known and understood (Verran \& Reid, 1987).

In an effort to recognize and use the abilities of each nurse, the Sioux Valley Hospital chose 'factoring' as the mechanism to place nurses into their respective role categories. Factoring involved self-assessment carried out by each nurse using a factoring tool. The head nurse also completed an assessment of each individual. During a 1-hour interview, the staff nurse and head nurse shared their assessments, observations, and goals for the project. Registered nurses on each unit were factored into the ADN (Case Associate) or BSN (Case Manager) job description in collaboration with their head nurse. A mutual decision for placement was reached (Koerner, 1988).

Another model enabling differentiation between nursing roles is a clinical ladder program. In contrast with differentiated practice, 'experience' is the only differentiating factor here. Clinical ladders were developed in the early 1980 s to cope with nurse recruitment and retention problems. Current interest in these programs is driven to retain experienced nurses who can improve quality. Retaining clinically competent nurses requires an appropriate salary and a work environment to support nurse autonomy. A clinical ladder is one means of increasing availability of these factors (Corley et al., 1994). The 
conceptual basis for many clinical ladder programs is Benner's work From novice to expert (1984). In it, she describes five levels of practitioner, namely novice, advanced beginner, competent, proficient and expert. A clinical ladder based on this can be constructed identifying five levels of clinical nursing. Subsequently, a review board determines the promotion of nurses on the clinical ladder, based on a portfolio of their professional abilities and accomplishments. On advancement to a new level, the nurses meet with the nurse manager to negotiate a new role (Corley et al., 1994). Martin \& McGuire (1990) described a three-level system used for the community health care setting. The job descriptions within this system included behavioral descriptors of group process skills, communication skills, job skill knowledge, professional development expectations, meeting requirements, record keeping, and coordination skill expectations (Martin \& McGuire, 1990).

In principle, differentiated practice and clinical ladders in American nursing concerns licensed personnel only. However, because of shortage of nurses and increased emphasis on cost containment, registered nurses must adjust to the reintroduction of unlicensed assistive personnel, also called nurse extenders or nurse assistants, into patient care areas (Barter \& Furmidge, 1994). The use of unlicensed personnel leads to a major change in registered nurse focus: from working primarily as sole practitioner to functioning as managers of patient care, responsible for the direction and supervision of assistant staff (Jung et al., 1994).

In the Netherlands community nursing agencies use a model that is in great extent comparable with the American model of differentiated practice used in hospitals (table 2). Because this model is described extensively above, only specific differences will be described here. In the Netherlands differentiation is made between community nurses (first level, comparable with the BSN) and community nurse auxiliaries (second level, comparable with the ADN). This differentiation is in line with the Dutch 'Nursing Profile' and based on education, responsibility and complexity of care (National Council for Health Care, 1988). In several agencies these general job descriptions are made applicable to community nursing in which distinction is made between junior and senior professionals (Wijdeven, 1989; Nollen, 1990; Vrielink, 1990; OttoCrefcoeur, 1995). The distinction between junior and senior can be interpreted as deriving from Benner's previously mentioned model to enable differentiation between nurses based on experience. In addition to the agencies for community nursing, differentiated practice is also implemented in hospitals. In most hospitals a distinction is made by emphasizing supervision and co-ordination of care in the role of the first level nurse (Nationaal Ziekenhuisinstituut - AortA, 1994). 
Within the Dutch job descriptions, attention is paid to responsibility and complexity of care. The complexity-concept is more extensively used than it is in the US. To decide whether or not nursing care is complex different measures have been developed in the Netherlands and are used in community nursing (Vrielink, 1990; Lapré \& Rutten, 1989; Hanrahan \& Lapré, 1990; Derckx et al., 1993; Van Amelsvoort et al., 1993; Jansen \& Kerkstra, 1993; Mostert, 1993; Van Til et al., 1994). Based on an analysis of several nursing models by Fawcett (1989), Jansen \& Kerkstra (1993) constructed an instrument in which criteria for complexity were divided in four categories: person (recipient of nursing actions), environment (recipient's significant others and the setting), health status (well and/or ill) and nursing activities. Examples of criteria that determine the complexity are: the patient's willingness to co-operate (person), the number of disciplines involved in the care-situation (environment), the presence of informal carers able to cope with the situation (environment), the existence of well-defined nursing diagnoses (health), and the requirement for specific technological activities (nursing activities). If a patient needs complex nursing care a community nurse has to be assigned (chapter 5 gives a more detailed description of this instrument).

In the United Kingdom three types of nurse are employed in district nursing: registered nurses, enrolled nurses and auxiliaries. Compared with the American situation in the United Kingdom the registered nurse fulfils the BSNrole and the enrolled nurse the ADN-role. However, training for enrolled nurses is being phased out in favor of a new single nursing qualification. In the UK differentiated practice is related to the 'skill mix-issue'. To describe skill mix, Gibbs ot al. (1991) made a distinction between 'grade mix' and 'skill mix'. Grade mix refers to the number of sisters, staff nurses, enrolled nurses and auxiliaries required; that is, the number of staff of each grade. Skill mix on the other hand refers to the skills and experience of staff within these grades: for example, how many years of experience does a staff nurse have in her present speciality and does she have a post basic qualification in that speciality (Gibbs et al., 1991). The grade-mix concerns a 'top-down' approach and is more likely to lead to rigid, inappropriate delivery of services. The professionally-led 'bottom-up' approach to skill mix has the potential to help cultivate and develop the new skills that are needed to cope with rapid and multiple changes (Cowley, 1993). However, in 1992 the NHS Value for Money Unit's report Skill Mix in District Nursing (1992) was published. The report recommended halving the numbers of qualified staff because, it was suggested, certain aspects of the nurses' traditional role can be carried out cost-effectively by less well-qualified staff (Griffiths \& Luker, 1994). According to Heath (1994) this report reduces nursing to a series of mechanistic tasks that could be counted and reallocated. In this model of skill mix highly 
qualified, skilled clinical professionals are asked to delegate the core of their work to unskilled workers and find themselves undertaking a supervisory or management role or even being made redundant (Heath, 1994).

Measures used in the United Kingdom to determine the number, but rarely the mix, of nurses required to provide the necessary care for patients are often based on patient dependency. Patient dependency on the nurse has been defined as 'the extent to which the patients' level of functional capacity dictates the time required for personal, technical, supportive and educative nursing care' (Durand, 1989). This type of measurement is not seen as appropriate to determine skill mix in nursing. Therefore, at a very basic level, improved measures of skill mix are required in order to avoid the limitations of indicators which reflect little more than grade and qualification mix. Given that nurses are an expensive commodity, the issue at the heart of skill mix from a managerial or pragmatic point of view is the need to identify those nursing tasks which require a professional qualification (usually the more technical aspects of nursing) and to allow less or unqualified people to undertake other more basic tasks (Gibbs et al., 1991). Skill mix is concerned with ensuring that appropriate skills are available to identify and meet needs, in the most cost-effective way. Three factors may be used to guide implementation of skill mix. First, decisions about delegation to less qualified staff should relate to the predictability of the particular practice situation, rather than to the nature of the task or the label or category attached to the client or patient. Second, priorities should be set and changes in practice evaluated using community nursing profiles of health needs. Finally, but most importantly, client participation should be explicitly included and encouraged in the skill mix process (Cowley, 1993).

In summary, the literature reviewed shows that in the USA, the Netherlands and the United Kingdom differentiation is made between at least two types of nurse based on level of education. Furthermore in some organizations 'experience' is used to make an (extra) distinction between nurses. Because of the cessation of enrolled nurse training in the UK, it seems that more attention is paid there to cost effectivity instead of professional recognition. Finally, both the American and British literature showed that there are possibilities for using assistive personnel in (community) nursing.

\subsubsection{Differentiated practice: the effects on job satisfaction}

As many articles on differentiated practice only contain points of view (Primm, 1988; McClure, 1991; Gibbs et al., 1991; Cowley, 1993; Barter \& Furmidge, 1994; Heath, 1994) whereas others are restricted to job descriptions (Primm, 1986, 1987; Johnson, 1988; Koerner, 1988; Kenyon et al., 1990; Hickey et al., 1991; Forsey ot al., 1993; Wiles \& Robison, 1994) only a few describe the 
outcomes of differentiated practice (Hesterly \& Sebilia, 1986; Koerner et al., 1989; American Organization of Nurse Executives, 1990; Malloch et al., 1990; Martin \& McGuire, 1990; Jung et al., 1994; Corley et al., 1994; Hutchens, 1994). The Dutch and British literature did not yield any information at all about the effects of differentiated practice. Consequently the effects presented here only concern the American situation.

The review of the literature did not yield extensively described methods used to measure the outcomes of differentiated practice systematically. In two articles, only surveys measuring job satisfaction were described. These instruments paid attention to pay, autonomy, task requirements, organizational policies, interaction, professional status (Koerner et al., 1989; Malloch et al., 1990), quality of care, enjoyment and time to do one's job (Malloch et al., 1990). In addition to these quantitative outcomes, qualitative and anecdotal data were collected during the implementation of differentiated practice. The outcomes reported in nursing literature were summarized by Hutchens (1994) (table 3). This summary is, to a great extent, based on the results of the Sioux Valley Hospital Experience.

Table 3 Improved job satisfaction as a result of differentialed nursing practice reported in nursing literature

Improved job satisfaction:

- higher scores on nursing satisfaction surveys

- positive anecdotal comments from nurses

- improved staff perceptions about components of work: degree of challenge; task requirements;

variety; opportunity to use judgement; opportunity to develop competencies

- improved commitment to work

- enhanced ability to accomplish work

- improved accountability

- stabilization of nursing positions (less turnover and less difficulty filling positions)

- managerial perceptions that practitioners' professional behaviours were enhanced, including: collaboration, accountability (for clients and unit) and professional self-development

- managerial role change shift from problem solver to mentor

Source: Hutchens (1994)

In addition to these positive effects, the Sioux Valley Hospital Experience also showed that nursing staff expressed mixed feelings about the project and the presence of two distinctly different practice roles. While the case associate nurses continue to enjoy nursing practice, some felt they had lost something because someone with another job status was practising beside them. Conversely, several BSN nurses expressed a great deal of job satisfaction because they could now practice 'what they were taught in school' (Koerner et al., 1989). 
The clinical ladder programs showed that the candidates received professional recognition from the organization and their peers as they proceeded through the program. The participants individually demonstrated self-growth in the areas of leadership, teaching, and role-modelling (Hesterly \& Sebilia, 1986; Martin \& McGuire, 1990). Other results showed that, according to the staff, clinical ladders had little effect on their recruitment and retention decisions (Martin \& McGuire, 1990; Corley et al., 1994). A program to establish better use of assistive personnel enabled registered nurses to delegate more patient care activities to nursing assistants. After implementation registered nurses noticed a decreased workload, and increased ability to supervise assistants. With respect to job satisfaction and coordination of care, no differences were found (Jung et al., 1994).

\subsubsection{Differentiated practice: the effects on quality of care}

To describe the effects of differentiated practice the overview of Hutchens (1994) will be presented again (table 4).

Table 4 Improved quality of care as a result of differentiated nursing practice reported in nursing literature

Improved quality of care:

- higher scores on client satisfaction surveys

- positive anecdotal comments from clients and families

- client requests to be readmitted to units that use differentiated nursing practice mode,s

- improved continuity in care

- improved quality assurance ratings and trending in incident reports

- positive comments and ratings from the surveyors of the Joint Commission of Accreditation of Healthcare Organizations

Source: Hutchens (1994)

From a patient care perspective, the participants in the clinical ladder system contributed a great deal through the continuing education program, unit-based in-service, patient care conferences, formalized care plans, protocol development, and quality assurance activities (Hesterly \& Sebilia, 1986). After implementation of the program with assistive personnel, registered nurses and patients noticed an improved quality of nursing care. More time and effort was being devoted to the delivery of basic physical and nutritional care. This increased availability and productivity of nursing assistant care givers may be perceived by patients as better care. In addition, registered nurses had more time to devote to the planning, coordination, and evaluation of patient care, which should further improve quality (Jung et al., 1994).

In summary, the results described in the literature reviewed show that positive effects on job satisfaction can be expected, especially for the first level nurses. As regards the quality of care positive effects were also described. 
However, the literature mainly contained job descriptions and considerations, whereas only a few projects studied the outcomes of differentiated practice systematically and consistently. A reliable approach is needed particularly for measuring the quality of care from a client perspective. Since it is possible that many patients are satisfied just because they are cared for and not because of the organizational principles used.

\subsubsection{Specialization: the concept and models}

Several areas of specialization are possible because the populations served by community health nurses are so diverse. The study of Riportella-Muller et al. (1991) identified population groups and health conditions considered appropriate for graduate-level community health nursing (CHN) practice and employment in the USA. According to 588 leaders in $\mathrm{CHN}$ service and education, the population groups most in need of graduate-prepared CHNs are the elderly, persons of low socioeconomic status, the homeless, adolescents, and the unemployed. The health conditions most in need of CHN services are AIDS, pregnancy and prenatal problems, low birth weight and infant mortality, stress-related illness, and Alzheimer's and other chronic diseases of the elderly. The findings provide the direction and justification for developing specialty options within $\mathrm{CHN}$ that correspond to these identified and changing needs (Riportella-Muller et al., 1991).

The population groups and health conditions mentioned by Riportella-Muller et al. (1991) are developed in the USA and United Kingdom by the employment of clinical nurse specialists (CNS) mainly. The literature reviewed showed different specialties: for example patients who are HIV infected (Bond et al., 1990a, 1990b; Bond et al., 1991; Haste \& MacDonald, 1992; Layzell \& McCarthy, 1993), patients who need critical care by means of advanced technological equipment such as pumps for tube feeding and intravenous therapy, ventilators, suctioning machines, cardiac and respiratory monitors (Bowyer, 1986; Roe-Prioir, 1994), terminally ill (e.g. the Macmillan nurse) (Bergen, 1991; Haste \& MacDonald, 1992; Nash, 1993; Griffiths \& Luker, 1994), elderly (Haste \& MacDonald, 1992), diabetes mellitus (Kyne, 1986; Moyer, 1989; Griffiths \& Luker, 1994), patients needing continence care or stoma care (Griffiths \& Luker, 1994), patients with lung cancer (McCorkle et al., 1989), and patients who need coronary care (Duddy \& Parahoo, 1992).

In the Netherlands specialized knowledge and skills are available by both the employment of CNSs (e.g. Wiegers, 1992; Kiers, 1993; Moons et al., 1994) and by means of the development of 'areas-of-special-expertise' for community nurses and community nurse auxiliaries. Areas-of-specialexpertise are constructed mainly based on patient categories. These areas are constructed where specific knowledge is needed for the caring of a 
particular patient category, where a lot of treatment is possible or where many changes occur in a specific category. Examples of these areas are: patients with AIDS, diabetes mellitus, patients with chronic non specific lung disease (CNSLD), patients with dementia, patients with rheumatism or patients who are incontinent. Within one (or more) of these areas a community nurse (auxiliary) keeps up to date with all the new developments, and attends educational programs to stay abreast of trends and innovations on these issues. Subsequently, in her team and agency she can be consulted by her peers for knowledge or skills. In addition to this special expertise, the nurse performs the general tasks within community nursing (Wiegers, 1992; Jansen \& Kerkstra, 1993; Van Haaren, 1994; Ketelaars, 1996). In 1992, almost half of the Dutch agencies for community nursing had areas-of-special-expertise in use, and about one third intended to construct these areas for community nurses and community nurse auxiliaries (see chapter 2 ).

\subsubsection{Specialization: the effects on job satisfaction}

Because nurses who deliver direct nursing care are the subject of this study, we pay attention to their job satisfaction in respect of specialization in community nursing. According to the review of the literature by Bergen (1991) the role of the community nurse does not seem to have diminished since the advent of specialist nurses. Community nurses (and other health professionals) generally valued the specialist service, despite the jotential conflicts over responsibility for care. However, two articles paid specific attention to the community nurse's attitude to the CNS (Haste \& MacDonald, 1992; Griffiths \& Luker, 1994). The results of these two studies are presented in the next paragraph.

Although the work of CNSs is seen to be worthwhile, integration of specialists into the community service is not as good as it might have been. Depending on the speciality, $20-50 \%$ felt that specialist nurses routinely or sometimes did work that district nurses should be doing. District nurses expressed significantly more dissatisfaction than specialists, with higher dissatisfaction scores on the factors of emotional climate, professional considerations, social significance, pay and professional preparation. They also tended to be more dissatisfied with working conditions. Nurses reported that they would have preferred to carry out the work of the CNSs themselves, but were prevented from doing so by heavy caseloads and lack of time. The majority of managers and nurses appeared to agree with recommendations made in the Cumbertege Report (1986) and in the review of community nursing in Wales (Welsh Office, Department of Health 1987), that district nurses should develop special responsibilities for particular patient groups to combine with district nursing duties. Many aspects of district nursing work are also being progressively deskilled and handed over to less qualified nursing staff and 
social services. In theory, the community nurse is left with more time to develop the specialized parts of her work, provided that work-load pressure does not increase as a consequence of NHS reorganisation. The desire of community nurses to become more knowledgeable in specialist areas is clear (Haste \& MacDonald, 1992; Griffiths \& Luker, 1994).

Because the areas-of-special-expertise in the Netherlands are a relatively new concept the effects on job satisfaction have not yet been extensively studied. In line with the United Kingdom literature presented above, it is expected and hoped that job satisfaction among nurses will remain or improve when they have an area-of-special-expertise. The results of the study from Van Bragt (1993) only partly support this expectation. In this study community nurses with an area-of-special-expertise gained more expertise in that area but a heavier workload as well. The nurses did not have enough time to carry out the tasks in their area.

\subsubsection{Specialization: the effects on quality of care}

Extensive research into the contribution of specialist nurses to quality of care is largely absent. However, in almost all the studies reviewed it is suggested that the quality of care is improved by specialist nurses working in community health care. Some of these studies will be presented here. The role of CNSs for the terminally ill was generally highly valued by patients and, particularly by carers. It has probably enabled patients to spend a larger portion of their illness at home and/or die there (Bergen, 1991). Research of a Complex Care Team showed that it had helped the patient to shorten or avoid hospitalization. Furthermore, patients and their families expressed complete satisfaction and gratitude for the care and service offered them (Bowyer, 1986). Evaluation of a 'coronary specialist nursing service' showed that most respondents found that information from nurses was always forthcoming, that the information received was well explained and that the amount of information was more than expected (Duddy \& Parahoo, 1992). According to several CNSs, the majority of community nurse managers felt that the introduction of specialist nurses had resulted in better patient care, improvement in district nurses' knowledge and better communication between hospital and community (Haste \& MacDonald, 1992). Finally, specialized AIDS home care has proved to be desirable from the perspective of the patients and their informal and professional caregivers (Layzell \& McCarthy, 1993; Moons et al., 1994).

Apart from all this positive information about the CNS-role, the study of Griffiths \& Luker (1994) showed that there was little consensus among the community nurses as to whether CNSs contributed to high-quality care in the community. In line with this, the studies of Christiaans et al. (1993) and 
Wiegers (1992) showed that the use of areas-of-special-expertise aiso can guarantee quality of care. Christiaans et al. (1993) showed that community nurses with an area-of-special-expertise took better care for their relationship with the client and that the situation was better analyzed when compared with community nurses without an area-of-special-expertise. Wiegers (1992) showed that there were no differences with the nursing of children with chronic non-specific lung disease (CNSLD) in quality of care between CNSs and community nurses with an area-of-special-expertise. This study showed that specific experience in this area (CNSLD) affects the quality of care.

In summary, it seems that there is a need for specialized expertise in community nursing. In a lot of situations this is delivered by clinical nurse specialists. However, community nurses are not always satisfied with a specialist working beside them and believe that they can deliver specialist care to a certain extent when they are given the opportunity (e.g. time and training). The development of areas-of-special-expertise may be an answer to this problem. As regards the effects on the quality of care, extensive research is again largely absent.

\subsection{Towards a model for evaluation of differentiated practice and specialization in community nursing}

The literature reviewed above showed that job characteristics in nursing roles will be changed in consequence of differentiated practice and specialization, and can therefore affect job satisfaction and quality of care. The review of the literature also showed that little quantitative information is available about the outcomes of differentiated practice and specialization in community nursing practice. Nothing at all was found on burnout in the literature reviewed. In order to study the effects of differentiated practice and specialization systematically, a research model was developed, based on the previously presented Job Characteristics Model and the experience with this model in other studies. Because the review of the literature presented above did not yield enough information about the specific effects of job- and individual characteristics, research on job satisfaction and burnout was studied to find additional factors.

The meta-analytic study (Blegen, 1993) identified thirteen variables that are often linked with nurses' job satisfaction. The results of this meta-analysis indicated that job satisfaction is most strongly and negatively related with stress and positively related to commitment. Autonomy, communication with supervisors, communication with peers, and recognition were moderately and positively related to job satisfaction. Low negative correlations were found 
between job satisfaction and locus of control. Analysis of the demographic variables provided evidence for small but stable relationships between age and education and job satisfaction. Nurses who were older were more satisfied and those with more educational qualifications were less satisfied with their work (Blegen, 1993). The study of Boumans (1990) showed that individual characteristics were related to job satisfaction as well as job characteristics. She found that nurses who experienced a lot of social support at work were more satisfied; whereas nurses who preferred autonomy in their work, and sought distraction when they were faced with problems were less satisfied with their jobs.

In respect of the three burnout-dimensions (emotional exhaustion, depersonalization and personal accomplishment), research among health care social workers showed that role conflict, role ambiguity, and lack of physical comfort were significantly related to emotional exhaustion. Depersonalization was related to high role conflict, low challenge, and low satisfaction with financial rewards. Significant job characteristics for the sense of personal accomplishment were: high challenge, high workload, greater satisfaction with financial rewards, low levels of role conflict, and low levels of conflict with professional values (Siefert et al., 1991). Among nurses, feelings of emotional exhaustion increased when the amount of workload increased. This relation was reduced when nurses had more autonomy in their work. A negative relation was found between the amount of challenge in the job and social support experienced with feelings of emotional exhaustion (De Jonge et al., 1994). Individual characteristics are also related to burnout in addition to job characteristics. The study of Boyle et al. (1991) showed that hardiness of personality, social support and ways of coping are related to burnout.

Last but not least it is important to study whether the effects of differentiated practice and/or specialization are the same for first level and second level nurses. For example, the role of second level nurse is conceived to become less attractive when differentiated practice is used. Consequently the variable 'nursing role' has to be included in the research model. Figure 2 presents the final model for the study of the effects of differentiated practice and specialization in community nursing. 
Figure 2 Model to evaluate the effects of differentiated practice ancl specialization in community nursing

\begin{tabular}{|c|c|c|c|}
\hline Work-redesign & $\begin{array}{c}\text { Job } \\
\text { characteristics }\end{array}$ & $\begin{array}{l}\text { Personal- and } \\
\text { work-outcomes }\end{array}$ & $\begin{array}{c}\text { Individual } \\
\text { characteristics }\end{array}$ \\
\hline \multirow[t]{3}{*}{$\begin{array}{l}\text { Differentiated } \\
\text { practice } \\
\text { Specialization }\end{array}$} & $\begin{array}{l}\text { Time pressure } \\
\text { Autonomy } \\
\text { Skill variety } \\
\text { Task clarity } \\
\text { Task identity } \\
\text { Growth at } \\
\text { work } \\
\text { Workload } \\
\text { Feedback } \\
\text { Task } \\
\text { significance }\end{array}$ & $\begin{array}{l}\text { Quality of care } \\
\text { Job satisfaction } \\
\text { Burnout }\end{array}$ & $\begin{array}{l}\text { Preferences } \\
\text { Coping } \\
\text { strategies } \\
\text { Experienced } \\
\text { social support } \\
\text { Biographic } \\
\text { characteristics }\end{array}$ \\
\hline & & Type of nurse & \\
\hline & & $\begin{array}{l}\text { Community } \\
\text { nurse } \\
\text { Community } \\
\text { nurse } \\
\text { auxiliary }\end{array}$ & \\
\hline
\end{tabular}

The research model suggests that several job characteristics will change when differentiated practice and specialization are used. As a result the quality of care, job satisfaction and burnout will change. Because the outcomes are also influenced by individual characteristics, these have to be taken into account as well. Finally, the outcomes will be directly influenced by the nursing role, and indirectly by moderating the relations with job- and individual characteristics.

\subsection{Discussion}

In this review we have organized the literature around differentiated practice and specialization in community nursing. As regards differentiated practice differentiation is made between at least two types of nurse based on education, complexity of care and experience mainly. Regarding specialization the review shows that specialized expertise in a lot of situations is delivered by clinical nurse specialists (CNSs). Besides, in the Netherlands areas-ofspecial-expertise are constructed to give community nurses and nurse auxiliaries the opportunity to improve their specialized knowledge.

Although it can be expected that both differentiated practice and specialization have consequences for job characteristics, and therefore affect job 
satisfaction, quality of care and burnout, the review didn't yield extensively information about this relationship. In a lot of studies only parts of the model presented in figure 2 were studied. Research based on this model will result in an overall impression of the effects of differentiated practice and specialization in (community) nursing. 


\subsection{References}

Algera J.A. (1983). 'Objective' and perceived task characteristics as a determinant of reactions by task performers. Joumal of Occupational Psychology, 56, 95-105.

Algera J.A., Flier H. van der \& Kamp L.J.Th. van der (1986). Causal modeling of quality of work. In: The Psychology of Work and Organization (Debus G. \& Schroiff H.W.) (pp. $175-182$ ). Amsterdam: Elsevier Science Publishers.

Amelsvoort F. van, Slingerland P. \& Verkaar E. (1993) Op kwaliteit aangesproken. Beslismodel voor de inzet van menskracht (Talking about quality. Model of decision for staffing). Utrecht: NIZW.

American Organization of Nurse Executives (1990). Current issues and perspectives on differentiated practice. Chicago: American Hospital Association.

Barter M. \& Furmidge M.L. (1994). Unlicensed assistive personnel. The Joumal of Nursing Administration 24(4), 36-40.

Benner P. (1984). From novice to expert. Menlo Park, California: Addison-Wesley Publishing Co.

Bergen A. (1991). Nurses caring for the terminally ill in the community: a review of the literature. Intemational Joumal of Nursing Studies 28(1), 89-101.

Blegen M.A. (1993). Nurses' job satisfaction: a meta-analysis of related variables. Nursing Research 42(1), 36-41.

Bond S., Rhodes T., Philips P., Setters J., Foy C. \& Bond J. (1991). Experience and preparation of community nursing staff for work associated with HIV infection and AIDS. Social Science \& Medicine 32(1), 71-76.

Bond S., Rhodes T., Philips P. \& Tierney A.J. (1990a). HIV infection and community nursing staff in Scotland-1, experience, practice and education. Nursing Times 86(44), 47-50.

Bond S., Rhodes T., Philips P. \& Tierney A.J. (1990b). HIV infection and community I.ursing staff in Scotland-2, Knowledge and attitudes. Nursing Times 86(45), 49-51.

Boston C.M. (1990). Introduction. In: Current issues and perspectives on differentiated practice. Chicago: American Organization of Nurse Executives, 1-3.

Boumans N.P.G. (1990). Het werk van verpleegkundigen in algemene ziekenhuizen: oen onderzoek naar werkaspecten en hun invloed op verpleegkundigen (The work of nurses in hospitals: a study about job characteristics and their effects on nurses). Maastricht: Rijksuniversiteit Limburg.

Bowyer C.K. (1986). The complex care team: meeting the needs of high-technology nursing at home. Home Healthcare Nurse 4(1), 24-29.

Boyle A., Grap M.J., Younger J. \& Thornby D. (1991). Personality hardiness, ways of coping, social support and burnout in critical care nurses. Joumal of Advanced Nursing 16, 850-857.

Bragt M.J.A.B. van (1993). Het gedifferentioerd en allround werken binnen de wijkverpleging. Een onderzoek bij Kruiswerk West-Brabant en Stichting Interkruis Noord-Kennementand (Specialization and non-specialization in community nursing. A study carried out at Kruiswerk West-Brabant and Stichting Interkruis Noord-Kennemertand). Maastricht: Rijksuniversiteit Limburg.

Broadbent D.E. (1985). The clinical impact of job design. British Joumal of Clinical Psychology 24, 33-44.

Christiaans M.A.C., Hurkmans M.H.J.J., Hollands L. \& Boumans N.P.G. (1993). Invloed van het deskundigheidsniveau op de kwaliteit van zorgverlening in complexe verpleegsituaties (Effects of the level of expertise on the quality of care in complex nursing situations). Verpleegkunde (1), 27-37.

Corcoran, S.A. (1986). Task complexity and nursing expertise as factors in decision making. Nursing Research 35(2), 107-112.

Corley M.C., Farley B., Geddes N., Goodloe L. \& Green P. (1994). The clinical ladder: impact on nurse satisfaction and turnover. The Joumal of Nursing Administration 24(2), 42-48. 
Cowley S. (1993) Skill mix: value for whom? Health Visitor 66(5), 166-168.

Cumberlege J. (1986). Neighbourhood nursing - A focus for care. Report of the Community Nursing Review. London: Her Majesty's Stationery Office.

Derckx E., Hollands L. \& Halfens R. (1993). Complexiteit van verpleegsituaties. Een meetinstrument voor de wijkverpleging (Complexity of nursing situations. A measuring instrument for community nursing). Tijdschrift voor Verpleegkundigen 24(23), 773-779.

Duddy I. \& Parahoo K. (1992). The evaluation of a community coronary specialist nursing service in Northern Ireland. Joumal of Advanced Nursing 17, 288-293.

Durand I. (1989). Nurse/patient dependency in community nursing. Nursing Times 85(5), 55-57.

Fawcett J. (1989). Analysis and evaluation of conceptual models of nursing. Philadelphia: F.A. Davis.

Forsey L.M., Cleland V.S. \& Miller B. (1993). Job descriptions for differentiated nursing practice and differentiated pay. The Joumal of Nursing Administration 23(5), 33-40.

Gibbs I., McCaughan D. \& Griffiths M. (1991). Skill mix in nursing: a selective review of the literature. Joumal of Advanced Nursing 16, 242-249.

Griffiths J. \& Luker K. (1994). Community nurse attitudes to the clinical nurse specialist. Nursing Times 90(17), 39-42.

Haaren E. van (1994). De expert: Carrière maken met de handen aan het bed (The expert: A career at the bedside). MGZ 22(4), 26-28.

Hackman J.R. \& Oldham G.R. (1975). Development of the Job Diagnostic Survey. Joumal of applied psychology 60(2), 159-170.

Hackman J.R. \& Oldham G.R. (1976). Motivation through the Design of Work: Test of a Theory. Organizational Behavior and human performance 16, 250-279.

Hackman J.R. \& Oldham G.R. (1980). Work redesign. Massachusetts: Addison-Wesley Publishing Company, Inc..

Hanrahan M.H. \& Lapré F. (1990). Project wijkziekenverzorgenden. Deskundigheden verdeeld (Project community nurse auxiliaries. Expertises divided). Bunnik: Landelijke Vereniging voor Thuiszorg.

Haste F.H. \& MacDonald L.D. (1992). The role of the specialist in community nursing: perceptions of specialist and district nurses. Intemational Joumal of Nursing Studies 29(1), $37-47$.

Heath I. (1994). Skill mix in primary care: should be used to match services to needs rather than to cut costs. British Modical Joumal 308, 993-994.

Hesterty S. \& Sebilia A.J. (1986). Recognizing clinical excellence. The Joumal of Nursing Administration 16(12), 34-38.

Hickey M., Billings D.M., Disch J., Eagleton B., Carty Farrell M., Turzan L. \& Vitello J.M. (1991). Competence statements for differentiated nursing practice in critical care. Focus on critical care 18(4), 286-293.

Hutchens G.C. (1994). Differentiated Interdisciplinary Practice. The Joumal of Nursing Administration 24(6), 52-58.

Jansen P.G.M. \& Kerkstra A. (1993). Functiodifferentiatie binnen de thuiszorg. De functies van wijkverpleegkundige, wijkverpleegster en gezinsverzorgende nader omschreven (Differentiated practice and specialization in home care. The roles of the community nurse, community nurse auxiliary and home help in detail). Utrecht: NIVEL.

Johnson J.H. (1988). Differences in the performances of baccalaureate, associate degree, and diploma nurses: A Meta-analysis. Research in Nursing \& Health 11, 183-197.

Jonge J. de, Janssen P. \& Landeweerd A. (1994). Effecten van werkdruk, autonomie en sociale ondersteuning op de werkbeleving van verplegenden en verzorgenden (Effects of workload, autonomy and social support on work-experience of nurses and nurse auxiliaries). Verpleogkunde (1), 17-26.

Jung F.D., Pearcey L.G. \& Philips J.L. (1994). Evaluation of a program to improve nursing assistant use. The Joumal of Nursing Administration 24(3), 42-47. 
Kenyon V., Smith E., Hefty L.V., Bell M.L., McNeil J. \& Martaus T. (1990). Clinical Competencies for Community Health Nursing. Public Health Nursing 7(1), 33-39.

Ketelaars C. (1996). Aftercare and specialised community nursing. Implications for patients with chronic obstructive pulmonary disease. PhD-thesis. Den Haag: Koninklijke Bibliotheek.

Keuning D. \& Eppink D.J. (1990). Management en Organisatie. Theorie en Toepassing (Management and organisations. Theory and Utilization). Leiden I Antwerpen: Stenfert Kroese Uitgevers.

Kiers J. (1993). Samenwerking wijkverpleegkundige en consulente kán ideaal zijn (Cooperation between community nurse and consultant can be ideal). MGZ 21(7), 22-25.

Koerner J.E. (1988). In South Dakota, nurses assess, then choose their practice level. Michigan Hospitals 3, 21-24.

Koemer J.E. (1990). The relevance of differentiated practice in today's environment. In: Current issues and perspectives on differentiated practice, Chicago, American Organization of Nurse Executives. (pp. 35-51).

Koerner J.E., Birch Bunkers L., Nelson B. \& Santema K. (1989). Implementing differentiated practice: the Sioux Valley hospital experience. The Joumal of Nursing Administration 19(2), 13-20.

Kyne D. (1986). The specialist role. Senior Nurse 5(4), 17-18.

Landeweerd J.A. \& Boumans N.P.G. (1988). Work satisfaction, health, and stress: a study of Dutch nurses. Work \& Stress 2(1), 17-26.

Lapré F. \& Rutten J. (1989). Patiententoewijzing. Eerste en tweede deskundigheidsniveau in de wijkverpleging (Patient-assignment. First level and second level of expertise in community nursing). Tijdschrift voor Verplegkundigen 43(11), 352-354.

Layzell S. \& McCarthy M. (1993). Specialist or generic community nursing care for HIVIAIDS patients? Joumal of Advanced Nursing 18, 531-537.

Malloch K.M., Milton D.A. \& Jobes M.O. (1990). A model for differentiated nursing piactice. The Journal of Nursing Administration 20(2), 20-26.

Martin S.D. \& McGuire M. (1990). A clinical ladder for the community health-care selting. Joumal of Community health nursing 7(4), $189-197$.

Maslach C. \& Jackson S.E. (1986) MBI: Maslach Bumout Inventory; manual research edition. Palo Alto: Consulting Psychologists Press, Inc.

McClure M.L. (1991). Differentiated nursing practice: concepts and consideration. Nursing Outhook 39(3), 106-110.

McCorkle R., Benoliel J.Q., Donaldson G., Georgiadou F., Moinpour C. \& Goodell B. (1989). A randomized clinical trial of home nursing care for lung cancer patients. Cancer 64(6), 1375-1382.

Mintzberg H. (1983). Structure in fives. Designing effective organisations. Englewood Cliffs: Prentice Hall.

Moons M., Kerkstra A. \& Biewenga T. (1994). Specialized home care for patients with AIDS: an experiment in Rotterdam, The Netherlands. Joumal of Advanced Nursing 19, 1132-1140.

Mostert H. (1993). De complexiteit van de verpleegsituatie. Op zoek naar een meetinstrument (Complexity of the nursing situation. Looking for a measuring instrument). Tijdschrift voor Verpleegkundigen 12, 408-413.

Moyer A. (1989). Caring for a child with diabetes: the effect of specialist nurse care on parents' needs and concerns. Joumal of Advanced Nursing 14, 536-545.

Murphy M. \& DeBack V. (1990). Myths and realities. In: Current issues and perspectives on differentiated practice (pp. 5-16). Chicago: American Organization of Nurse Executives.

Nash A. (1993). Reasons for referral to a palliative nursing team. Joumal of Advanced Nursing 18, 707-713.

Nationaal Ziekenhuisinstituut - AortA. Functiedifferentiatio binnen de intramurale verpleging (Differentiated practice in hospitals). Utrecht: Nationaal Ziekenhuisinstituut - AortA. 
National Council for Health Care (1988). Verpleogkundig beroepsprofiel (Nursing profile). Zoetermeer: National Council for Health Care.

National Health Service Management Executive Value for Money Team (1992). The nursing skillmix in the district nursing service. London: HMSO.

Nollen C.L.M. Zorgkwaliteit van twee deskundigheidsniveaus binnen complexe verpleegsituaties in de wijkverpleging (Quality of care by two levels of expertise in complex nursing situations in community nursing). Maastricht: Rijksuniversiteit Limburg.

Otto-Crefcoeur V. (1995). Het evaluatiemodel junior/senior (The evaluationmodel junior/senior). Tijdschrift voor Verploogkundigen (4), 114-118.

Primm P.L. (1986). Entry into practice: competency statements for BSNs and ADNs. Nursing Outbok 34(3), 135-137.

Primm P.L. (1987). Differentiated Practice for ADN- and BSN-Prepared Nurses. Joumal of Professional Nursing 4, 218-225.

Primm P.L. (1988). Implementation of differentiated practice through differentiated case management. Michigan Nurse (9), 33.

Primm P.L. (1990). Approaches and strategies. In: Current issues and perspectives on differentiated practice (pp. 17-34). Chicago: American Organization of Nurse Executives.

Riportella-Muller R., Selby M.L., Salmon M.E., Quade D. \& Legault C. (1991). Specialty Roles in Community Health Nursing: A National Survey of Educational Needs. Public Health Nursing 8(2), 81-89.

Roberts K.H. \& Glick W.H. (1981). The job characteristics approach to task design: A critical review. Joumal of Applied Psychology 66, 193-217.

Roe-Prior P., Watts R.J. \& Burke K. (1994). Critical care clinical nurse specialist in home health care: survey results. Clinical Nurse Specialist 8(1), 35-40.

Siefert K., Jayaratne S. \& Chess W.A. (1991). Job satisfaction, burnout, and turnover in health care social workers. Health and social work 16(3), 193-202.

Soeken K.L. \& Prescott PA. (1991). Patient intensity for nursing index: the measurement model. Research in Nursing \& Health 14, 297-304.

Strickland B. \& Neely, S. (1995). Using a standard staffing index to allocate nursing staff. The Joumal of Nursing Administration 25 (3), 13-21.

Taylor B. (1985). The effect of DRGs on home health care. New Jersey's experience suggests DRGs are increasing the need for home care for more acutely ill patients. Nursing Outlook 33(6), 288-289.

Til C. van, Halfens R. \& Hollands L. (1994). Deskundigheidsniveaus: gerelateerd aan complexiteit van wijkverpleegkundige zorg (Levels of expertise: correlation with complexity of nursing care). Verploegkunde (1), 28-38.

Turton P. (1984). Nurses working in the community. Nursing Times 5, 40-42.

Verheij R.A. \& Kerkstra A. (1992). Intemational Comparative Study of Community Nursing, Aldershot: Avebury.

Vorran J.A. \& Reid P.J. (1987). Replicated testing of the nursing technology model. Nursing Research 36(3), 190-194.

Vrielink H. (1990). Deskundigheid op maat. Beleidsnota $1 \theta$ en $2 \theta$ deskundigheidsniveau (The right expertise. Policy-document first and second level of expertise). Amsterdam: Stichting Amsterdams Kruiswerk.

Welsh Office, Department of Health (1987). Nursing in the community: a team approach for Wales. Report of the reviow of Community Nursing in Wales. Cardiff: Welsh Office.

Wiegers T.A. (1992). Evaluatio van modellen voor aansluiting tussen intramurale specialistische en extramurale verploegkundige cara-zorg voor kinderen (Assessment of models for the interface between intramural spocialist CNSLD care and extramural CNSLD nursing care for children). Utrecht: NIVEL.

Wijdeven C. (1989). Partners op verschilfond niveau (Partners on different love/s). Maastricht: Rijksuniversiteit Limburg. 
Chapter 3

Wiles R. \& Robison J. (1994). Teamwork in primary care: the views and experiences of nurses, midwives and health visitors. Joumal of Advanced Nursing 20, 324-330. 


\section{THE EFFECTS OF JOB CHARACTERISTICS \\ AND INDIVIDUAL CHARACTERISTICS \\ ON JOB SATISFACTION AND BURNOUT \\ IN COMMUNITY NURSING ${ }^{1}$}

\subsection{Summary}

The aim of this chapter is to describe job satisfaction and burnout among two categories of community-based nurses $(n=402)$ in the Netherlands taking account of job and individual characteristics. Results show that these nurses are moderately satisfied with their jobs and the effects of burnout are average. Further, community nurses are less satisfied and have experienced burnout to a greater extent than community nurse auxiliaries. Both job characteristics and individual characteristics are related to job satisfaction and burnout. However, job satisfaction is affected to greater extent by job characteristics whereas burnout is more often a result of individual characteristics. As research in this area is scarce and home care is changing radically, these results may be valuable in coping with change without losing sight of nursing's professional values.

\subsection{Introduction}

Nurses in the community are faced with a lot of changes: a growing number of the elderly demanding home care; patients are discharged from hospitals quicker and sicker; special expertise is required from nurses to deliver technical nursing interventions; and governments want an efficient use of personnel in a cost-effective way (Turton, 1984; Taylor, 1985; Kenyon et al,, 1990; Gibbs et al., 1991; Jansen \& Kerkstra, 1993). Agencies for community nursing are being forced to use a more business-like approach. Undoubtedly these changes will have consequences for nurses working in the community. To cope with the changes and guarantee quality of care, it is important to know how satisfied nurses are with their jobs, to what degree they experience burnout and what characteristics influence satisfaction and burnout. A review of the literature did not yield extensive information about job satisfaction and burnout in community nursing, making research in this area even more

This chapter is an adapted version of the article Jansen P.G.M., Kerkstra A., Huijer AbuSaad H. Zee J. van der (1996). The effects of job characteristics and individual characteristics on job satisfaction and burnout in community nursing. Intemational Journal of Nursing Studies 33(4), 407-421. 
relevant. Due to the paucity of research in this area and because of the relevance of the problem for community nursing care, a research project was undertaken in the Netherlands which addressed the following research questions among others:

1. What are the differences in job characteristics, individual characteristics, job satisfaction and bumout between community nurses and community nurse auxiliaries?

2. What job characteristics are related to job satisfaction and burnout in community nursing, and are there differences in this between community nurses and community nurse auxiliaries?

3. What individual characteristics are related to job satisfaction and burnout in community nursing, and are there differences in this between community nurses and community nurse auxiliaries?

To answer these questions the model presented in figure 1 was used.

Figure 1 Research model

\begin{tabular}{l}
\hline $\begin{array}{c}\text { Job } \\
\text { characteristics }\end{array}$ \\
\hline time pressure \\
autonomy \\
skill variety \\
task clarity \\
task identity \\
growth at work \\
feedback \\
lask significance
\end{tabular}

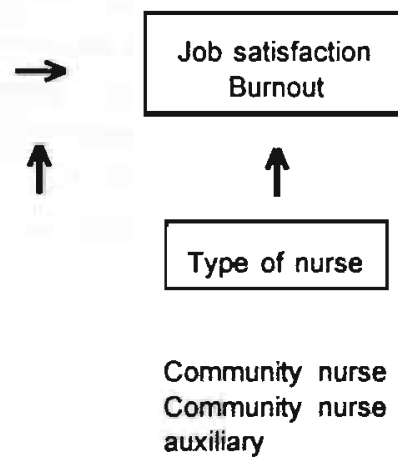

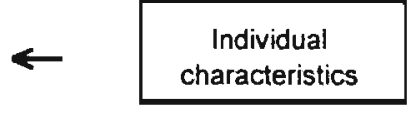

Preferences

Coping strategies

Experienced

social support

Biographical

characteristics

\subsection{Review of the literature}

\subsubsection{Types of community nurse in the Netherlands}

In the Netherlands a distinction is made based on the Dutch 'Nursing Profile' (National Council for Health Care, 1988) between two types of nurses in community nursing: community nurses and community nurse auxiliaries. In line with this profile, complexity of nursing care and the range of responsibilities are in most Dutch community nursing agencies used as the distinguishing characteristics between community nurses and community nurse auxiliaries (Jansen \& Kerkstra, 1993). The different types of Dutch community nurses can be compared with the difference between the registered nurse and enrolled nurse in the United Kingdom (Verheij \& Kerkstra, 1992) or between nurses with bachelor's and associate's degree in the United States (American Organization of Nurse Executives, 1990). 
Professionally, there is a difference between nurses and nurse auxiliaries; but, hierarchically, they are both managed by a head nurse.

\subsubsection{Job satisfaction}

Different theoretical models can be used to measure job satisfaction. For example, the Job Characteristics Model (JC-Model) (Hackman \& Oldham, 1980), the Job Demand Control Model (JDC-Model) (Karasek \& Theorell, 1990) and the Demand Control Support Model (DCS-Model) (Johnson \& Hall, 1988). The JC-Model was developed for redesigning work and shows that different job characteristics are related to job satisfaction: skill variety, task identity, task significance, autonomy and feedback. In the JDC-Model, psychological demands (workload) and decision latitude (autonomy) are the central components. Johnson \& Hall (1988) added the dimension of social support to this model. Research showed that several of the factors mentioned in the models were related to job satisfaction among nurses. For example, a meta-analytic study (Blegen, 1993) identified thirteen variables that were often linked with nurse's job satisfaction. In this study, hospitals were the most common work sites. The results of this meta-analysis indicated that job satisfaction was most strongly and negatively related with stress and positively related to commitment. Autonomy, communication with supervisors, communication with peers, and recognition were moderately and positively related to job satisfaction. Low negative correlations were found between job satisfaction and locus of control, whereas fairness in reward distribution was positively related. Analyses of the demographic variables provided evidence for small but stable relationships between age, education and job satisfaction. Nurses who were older were more satisfied and the better educated were less satisfied with their work (Blegen, 1993). Boumans study (1990) showed that, in addition to job characteristics, individual characteristics were also related to job satisfaction. She found that nurses who experienced a lot of social support at work were more satisfied, whereas nurses who preferred autonomy in their work and sought distraction when they were faced with problems were less satisfied with their jobs.

Only a few studies were found which focused on community nursing. The study of Parahoo \& Barr (1994) showed that community nurses, working with people with a mental handicap, listed several factors that contributed to job satisfaction. These were: multi-disciplinary team work, involvement with patients, progress of patients, varied aspects of work, autonomy and appreciation of patients. Factors contributing to job dissatisfaction were: heavy caseload, administrative work, lack of resources, lack of communication, lack of recognition from other staff and lack of support from management. Seymour \& Buscherhof (1991) found that dissatisfaction among nurses was mainly caused by structural problems (i.e. those created by 
inadequate working conditions and counterproductive attitudes within employing agencies) and bad remuneration and benefits. The study by Wade (1993) showed that there were differences in job satisfaction between types of nurse within community nursing. Practice nurses were significantly more satisfied with their jobs than district nurses and health visitors. Riordan (1991) collected data from a sample of community health, school health, and home health nurses. Prestige had the highest positive correlation with job satisfaction and regression analysis showed that it was the single significant predictor. The correlation matrix showed that three other subscales (autonomy, social interaction, and organizational requirements) correlated moderately and positively with job satisfaction. Weak positive relationships were found with years of work, years on the job, age, and years of education. Pay was not related to job satisfaction for these nurses. In comparing hospital-based nurses with home health nurses, research showed that home health nurses were more satisfied than hospital nurses with the opportunities to use their skills, participate in important and worthwhile activities, and in their overall feelings of self-fulfillment. In addition, home health care nurses were more satisfied with their opportunities to give a lead to others connected with their jobs, to share in deciding on methods and procedures, and with their opportunities to share in setting organizational goals (Curreri et al., 1985).

\subsubsection{Burnout}

Burnout is a negative experience and results from the interaction between the individual and the environment. Although a subjective phenomenon, burnout has a clear relationship with the organizational setting in which it occurs. In essence, burnout is a response to chronic occupational stress (Handy, 1988: Sullivan, 1993). Maslach \& Jackson (1986) defined burnout as 'a syndrome of emotional exhaustion, depersonalization and reduced personal accomplishment that can occur among individuals who do 'people work' of some kind'. This definition includes three dimensions of burnout. Emotional exhaustion involves individuals feeling they are no longer able to give of themselves at a psychological level. Depersonalization refers to the development of negative, cynical attitudes and feelings about one's patients. Reduced personal accomplishment is the tendency to evaluate oneself negatively, particularly in relation to one's work with patients.

Review of the literature from Moore \& Simendinger (1982) showed that factors contributing to occupational stress can be divided into three sources relating to the workplace (factors at the institutional-, unit- and, patient-level) and a fourth source focusing on stress at the personal level (CohenMansfield, 1989). McGrath et al. (1989) showed that moderate or high stress levels in nursing were caused by having insufficient time to perform duties to 
the nurse's satisfaction and to the rationing of scarce services or resources. In respect of the three burnout-dimensions, research among health care social workers showed that role conflict, role ambiguity, and lack of physical comfort were significantly related to emotional exhaustion. Depersonalization was related to high role conflict, low challenge, and low satisfaction with financial rewards. Significant job characteristics in the sense of personal accomplishment were: high challenge, high workload, greater satisfaction with financial rewards, low levels of role conflict, and low levels of conflict with professional values (Siefert et al., 1991). Among nurses, feelings of emotional exhaustion increased when the amount of workload increased. This relation was reduced when nurses had more autonomy in their work. A negative relation was found between the amount of challenge in the job and social support experienced and feelings of emotional exhaustion (De Jonge et al., 1994).

In addition to job characteristics, individual characteristics are related to burnout. The study of Boyle et al. (1991) among critical care nurses showed that personality hardiness, social support and ways of coping were related to burnout. Hardy persons have a higher sense of commitment to work and self and feel a greater sense of control over their lives, viewing stressors as potential opportunities for change. Social support had a negative relationship to burnout too. Both work-related and nonwork-related sources of social support were significantly related to burnout. With respect to coping this study showed that problem-focused coping was not related to burnout, whereas use of emotion-focused coping was positively related to burnout. Peer-support and support from supervisors were the two most commonly reported factors that assisted nurses in coping with job-related stressful events (Boyle et al., 1991). Similar relations were found by Hare et al. (1988).

Only a few studies were found on community nursing. Responses of community health nurses identified major sources of stress as factors related to quantitative work overioad, uncooperative family members and patients, unfamiliarity with situations, inability to reach physicians, and personal situations. The intensity of stressors was significantly different by age, in that older nurses experienced less stress (Walcott-McQuigg \& Ervin, 1992). McGrath et al. (1989) showed that direct contact with patients and the emotional demands of patients caused community-based nurses more stress when compared with hospital-based nurses. In another study, the stress experienced by community nurses decreased as the nurses: recognized an improvement in the quality of care the patient received; were given adequate time to manage the requirements of the job, or developed competency in the performance of the tasks assigned in the health setting (Boswell, 1992). 


\subsection{Method}

\subsubsection{Subjects and procedure}

The subjects in this study were community nurses and community nurse auxiliaries employed by ten agencies for community nursing scattered over the Netherlands. 310 community nurses and 92 community nurse auxiliaries filled in a structured questionnaire out of the total group of 441 nurses. This led to a response-rate of $91 \%$. Seven percent of the nurses were male and $93 \%$ female. The distribution of age and employment of the subjects is presented in table 1.

Table 1 Distribution of age and employment (hours per week)

\begin{tabular}{|c|c|c|c|c|}
\hline & $\begin{array}{l}\text { Total group } \\
(n=402)\end{array}$ & $\begin{array}{l}\text { Community nurses } \\
(n=310)\end{array}$ & $\begin{array}{l}\text { Community } \\
(n=92)\end{array}$ & nurse auxiliaries \\
\hline \multicolumn{5}{|c|}{ distribution of age: } \\
\hline $20-30$ years & $28.8 \%$ & $26.9 \%$ & $35.9 \%$ & \\
\hline $31-40$ years & $37.6 \%$ & $36.7 \%$ & $44.5 \%$ & \\
\hline $41-50$ years & $24.6 \%$ & $24.9 \%$ & $17.4 \%$ & \\
\hline $51-60$ years & $9.0 \%$ & $11.5 \%$ & $2.2 \%$ & \\
\hline mean age & 36.8 years & 37.7 years *** & 33.9 years ${ }^{\star *}$ & $(p \leq .001)$ \\
\hline \multicolumn{5}{|c|}{ employment (hours per week): } \\
\hline-20 hours & $14.6 \%$ & $14.0 \%$ & $16.3 \%$ & \\
\hline $21-30$ hours & $24.2 \%$ & $19.2 \%$ & $34.8 \%$ & \\
\hline $31-37$ hours & $39.8 \%$ & $41.4 \%$ & $36.9 \%$ & \\
\hline 38 hours & $21.4 \%$ & $25.4 \%$ & $12.0 \%$ & \\
\hline mean hours & 29.8 hours & 30.4 hours ** & 28.0 hours $^{* * 4}$ & $(p \leq .01)$ \\
\hline
\end{tabular}

The figures in table 1 show that the majority of both community nurses and community nurse auxiliaries are between 31 and 40 years old, and that the nurses are older than the auxiliaries. The years of experience in home care are connected with this distribution of age. The community nurses in our sample have significantly more experience in home care than the community nurse auxiliaries: the mean scores are 8.5 years and 5.4 years respectively. Compared with a representative study of the work of community nurses and auxiliaries in the Netherlands (Vorst-Thijssen et al, 1990), in our sample, nurses between 20 and 30 years of age were less well represented and nurses between 41 and 50 years were better represented. Consequently the subjects in our sample were relatively old and had a lot of experience in home care. The second part of table 1 shows that, in our sample, nurses were employed for more hours than nurse auxiliaries. This is comparable with national figures: in $1992,22 \%$ of the nurses and $13 \%$ of the auxiliaries were employed for 38 hours per week (Netherlands Central Bureau of Statistics, 1994). 


\subsubsection{Measuring instruments}

A questionnaire was developed based on the Algera questionnaire (Algera, 1981; Algera et al., 1986) to characterize the nursing roles and measuring job satisfaction. Algera modified and enlarged the Job Diagnostic Survey (Hackman \& Oldham, 1980). Prior to the research conducted by the authors of this study, Boumans (1990) used the Algera questionnaire for nurses in hospitals. Based on these results, a questionnaire was constructed to assess 8 job characteristics (measured by 24 items): time pressure, autonomy, job clarity, skill variety, task identity (the degree to which a job requires completion of a whole and identifiable piece of work, i.e. doing assessments and diagnostics), possibilities for growth at work, feedback and task significance $(=$ the degree to which the job has a substantial impact on the lives of other people in the immediate organization and in the world at large). Cronbach's $a$ of the subscales ranged from .67 to .79 .

Several individual characteristics were measured: preferences, coping strategies, experienced social support and biographical characteristics. Preferences were measured by 6 subscales ( 33 items): preference for career, prestige, autonomy, co-operation, variety and absence of time pressure. The internal consistency of each subscale was high (Cronbach's $a$ ranged from .75 to .93). To measure coping strategies the Utrecht Coping List (UCL) (Schreurs et al., 1988) was used. This questionnaire consists of three subscales: an active way of handling problems ( 7 items, $a=76)$, remaining passive (11 items, $\alpha=.71$ ) and seeking social support ( 6 items, $\sigma=.80$ ). Social support experienced at work was measured by the Organizational Stress Questionnaire (VOS-D) (Bergers et al., 1986) including 2 subscales: social support experienced from the supervisor $(a=.91)$ and social support experienced from peers $(\alpha=.71)$. Finally, three biographical characteristics were used in this study: age, sex and hours of employment. These biographical characteristics, together with the variable 'type of nurse' are used as control variables in the regression analysis. In other studies similar control variables were used (Boumans, 1990; Le Blanc, 1994).

Based on the study of Boumans (1990), job satisfaction was measured by 8 subscales (measured by 43 items): satisfaction with the quality of care, general work satisfaction, supervisory satisfaction, satisfaction with peers, patient-contact, patient-assignment, clarity and growth at work. The internal consistency of each subscale was acceptable to high (Cronbach's $a$ ranged from .64 to .92). In this chapter the overall score is taken into account $(\sigma=.70)$.

To measure burnout the Dutch version of the Maslach Burnout Inventory (MBI-NL) was used (Schaufeli \& Van Dierendonck, 1994). The MBI-NL 
consists of three subscales designed to assess the frequency (how often persons have these feelings) of three aspects of burnout: emotional exhaustion, depersonalization and personal accomplishment. A high degree of burnout was reflected in high scores on the emotional exhaustion and depersonalization subscales and in low scores on the personal accomplishment subscale. The inventory is self-administered and the frequency with which the respondents experience feelings related to each subscale is assessed in terms of 22 seven-point Likert type questions ( $0=$ never, $6=a l w a y s)$. Items 12 and 16 were not included because other studies showed that these items do not load on one factor only (Schaufeli \& Van Dierendonck, 1994). Eight items assess emotional exhaustion, depersonalization is measured by five items and seven items assess feelings of personal accomplishment. The internal consistency of each subscale is acceptable to high (Cronbach's $a$ is respectively .86, .64 and .77). To get a better idea of the scores on the three dimensions a comparison was made with a 'standard for nurses' presented in the study by Schaufeli \& Van Dierendonck (1994). In that study scores from 2,500 nurses in the Netherlands were analyzed and the mean scores on the three dimensions were presented as the standard. The authors emphasize that these standards are not yet definitive. On a scale from $0-6$ for emotional exhaustion the standard is 1.9 (scores between 1.1 and 2.5 are average), for depersonalization the standard is 1.4 (scores between 0.6 and 1.8 are average), and for personal accomplishment the standard is 3.9 (scores between 3.4 and 4.3 are average).

Mean scores were calculated and regression analysis was carried out to analyse the data. To measure whether there were significant differences in effects of the characteristics on job satisfaction and burnout between nurses and auxiliaries, the B's in the regression analysis were further analyzed. Owing to multicollineality, it was not possible to use interaction-variables in the analysis. And as it is incorrect just to compare the size of the B's of the two groups (with different sample sizes) we were forced to use another method. Accordingly the 'T-test for difference in coefficients from separate subgroup regressions' was used (Hardy, 1993).

\subsection{Results}

\subsubsection{Differences in mean-scores on the variables between the two types of nurse}

First, the means of all variables are presented in table 2. For all variables it is considered that a higher score means that the variable is present to a higher extent. T-tests were used to decide if differences between community nurses and community nurse auxiliaries were significant. 
Table 2 shows at first that there are differences in job characteristics between the two types of nurses. Community nurses are subject to a greater pressure in respect of time, the variety and the nature of their work (i.e. doing assessments and diagnostics) is greater and they receive less feedback than nurse auxiliaries. The great difference in scores on 'task identity' prevented this variable from being included in the regression analysis: $9 \%$ of the nurses versus $62 \%$ of the auxiliaries scored 1 or 2 whereas $67 \%$ of the nurses versus $1 \%$ of the auxiliaries scored 5,6 or 7 . Inclusion of this variable would contribute nothing to the effects of making assessments and diagnostic work but only provide information about the effects of being a nurse or an auxiliary. In addition to these job characteristics, the nurses and auxiliaries differed on two individual characteristics: nurses do prefer autonomy in their work to greater extent and auxiliaries do experience more social support from their head nurses. In respect of job satisfaction, the data shows that both types of nurses are moderately satisfied. On a five point-scale, the mean scores varied between 3.14 and 3.96. The data also showed that community nurse auxiliaries were overall better satisfied than community nurses. The scores on the subscales show that this difference occurs in different aspects. Compared with registered nurses, nurse auxiliaries experience more satisfaction with their work in general, are more satisfied with their head nurse and the contacts with patients. They are also more satisfied with the clarity of their job description and opportunities for growth at work. Finally, the burnout-scores show that there are significant differences between nurses and auxiliaries on all the three dimensions. Nurse auxiliaries are significantly less emotionally exhausted and depersonalized than nurses and feel themselves more competent personally for the work they are doing. 


\begin{tabular}{|c|c|c|c|c|}
\hline \multirow[b]{2}{*}{ Variables } & \multicolumn{2}{|c|}{$\begin{array}{l}\text { Community } \\
\text { nurses }(n=310)\end{array}$} & \multicolumn{2}{|c|}{$\begin{array}{l}\text { Community nurse } \\
\text { auxiliaries ( } n=92 \text { ) }\end{array}$} \\
\hline & Mean & SD & Mean & SD \\
\hline \multicolumn{5}{|l|}{ Job characteristics (scale 1-7): } \\
\hline time pressure & $5.13^{* *}$ & 1.13 & $4.75^{* *}$ & 1.08 \\
\hline autonomy & 4.35 & 1.23 & 4.62 & 1.29 \\
\hline task clarity & 5.86 & 0.60 & 5.91 & 0.62 \\
\hline skill variety & $5.27^{* *}$ & 0.78 & $4.98^{* *}$ & 0.81 \\
\hline task identity & $5.32^{* * *}$ & 1.76 & $2.20^{\mathrm{nn*}}$ & 1.09 \\
\hline growth at work & 4.09 & 1.38 & 4.18 & 1.25 \\
\hline feedback & $4.38^{* *}$ & 0.90 & $4.70^{* *}$ & 0.85 \\
\hline task significance & 5.22 & 0.68 & 5.36 & 0.79 \\
\hline \multicolumn{5}{|l|}{$\begin{array}{l}\text { Individual characteristics: } \\
\text { preferences (scale 1-5): }\end{array}$} \\
\hline for career & 3.56 & 0.84 & 3.42 & 0.85 \\
\hline for prestige & 3.43 & 0.65 & 3.43 & 0.67 \\
\hline for autonomy & $3.74^{* *}$ & 0.57 & $3.56^{* *}$ & 0.54 \\
\hline for co-operation & 3.47 & 0.56 & 3.46 & 0.57 \\
\hline for skill variety & 3.82 & 0.56 & 3.72 & 0.55 \\
\hline \multicolumn{4}{|l|}{ copingstrategies (scalo 1-4): } & 0.60 \\
\hline active approach & 2.95 & 0.41 & 2.89 & 0.39 \\
\hline passive approach & 1.96 & 0.31 & 1.92 & 0.34 \\
\hline seeking social support & 2.65 & 0.48 & 2.59 & 0.49 \\
\hline \multicolumn{5}{|l|}{ social support experienced (scale 1-4): } \\
\hline from head nurse & $2.90^{* *}$ & 0.76 & $3.16^{* *}$ & 0.60 \\
\hline from peers & 3.29 & 0.37 & 3.37 & 0.37 \\
\hline \multicolumn{5}{|l|}{ Job satisfaction (scale 1-5): } \\
\hline overall score & $3.55^{\star \star \star \star}$ & 0.36 & $3.72^{*+4 *}$ & 0.32 \\
\hline with quality of care & 3.55 & 0.55 & 3.61 & 0.47 \\
\hline general work satisfaction & $3.68^{* * *}$ & 0.65 & $3.96^{\mathrm{k*n}}$ & 0.63 \\
\hline supervisory satisfaction & $3.21^{\ldots * *}$ & 0.85 & $3.56^{* * *}$ & 0.70 \\
\hline with peers & 3.85 & 0.45 & 3.86 & 0.49 \\
\hline with patient-contacts & $3.80^{*}$ & 0.42 & $3.91^{*}$ & 0.40 \\
\hline with patient-assignment & 3.24 & 0.85 & 3.14 & 0.84 \\
\hline with clarity & $3.41^{* * *}$ & 0.48 & $3.64^{* \cdots+}$ & 0.41 \\
\hline with growth at work & $3.35^{\star \star \star}$ & 0.72 & $3.63^{* * *}$ & 0.54 \\
\hline \multicolumn{5}{|l|}{ Burnout dimensions (scale 0-6): } \\
\hline emotional exhaustion & $2.15^{\star}$ & 0.84 & $1.93^{\star}$ & 0.84 \\
\hline depersonalization & $1.15^{\star}$ & 0.68 & $0.95^{*}$ & 0.75 \\
\hline personal accomplishment & $4.04^{*}$ & 0.47 & $4.17^{\star}$ & 0.51 \\
\hline
\end{tabular}

"p $p .05, \Rightarrow p \leq .01, " * 0 \leq .001$

\subsubsection{Effects of job characteristics on job satisfaction and burnout}

Table 3 presents the results of regression analysis with the job characteristics as independent variables. Two stages were used to build the regression models. In the first stage, four control variables were entered followed by the job characteristics in the second stage. In comparing the Adjusted $R^{2}$ between the two stages it will be obvious to what extent the two groups of variables 
contribute to the model. Both stages include forced entry. This means that all variables presented in the table are included in every model. In the table, only the B's at a significant level in the final model are presented.

Table 3 Results of regression analysis for job satisfaction and burnout with job characteristics as independent variables among the total group ( $n=402)$

\begin{tabular}{|c|c|c|c|c|c|}
\hline & & $\begin{array}{l}\text { Job } \\
\text { satisfaction }\end{array}$ & $\begin{array}{l}\text { Emotional } \\
\text { exhaustion }\end{array}$ & $\begin{array}{l}\text { Depersona- } \\
\text { lization }\end{array}$ & $\begin{array}{l}\text { Personal } \\
\text { accomplishment }\end{array}$ \\
\hline 1) & $\begin{array}{l}\text { Control variables: } \\
\text { type of nurse } 11 \\
\text { age } \\
\text { sex } \\
\text { hours of employment }\end{array}$ & $\begin{array}{l}-.14^{* *} \\
- \\
-.14^{*}\end{array}$ & $\begin{array}{l}-11^{*} \\
-17^{* * *}\end{array}$ & $\begin{array}{l}.11^{*} \\
-- \\
- \\
--\end{array}$ & $\begin{array}{l}- \\
- \\
-\end{array}$ \\
\hline \multicolumn{2}{|c|}{ Adj $R^{2}$ Change } & .07 & .03 & .02 & .00 \\
\hline 2) & $\begin{array}{l}\text { Job characteristics: } \\
\text { time pressure } \\
\text { autonomy } \\
\text { task clarity } \\
\text { skill variety } \\
\text { growth at work } \\
\text { feedback } \\
\text { task significance }\end{array}$ & $\begin{array}{l}- \\
-11^{*} \\
.11^{*} \\
.26^{* * *} \\
.27^{* * *} \\
-\end{array}$ & $\begin{array}{l}.18^{n * *} \\
-.16^{\text {***}} \\
- \\
- \\
- \\
- \\
-\end{array}$ & $\begin{array}{l}-- \\
-.15^{* *} \\
- \\
-.13^{*} \\
- \\
- \\
-.23^{* *}\end{array}$ & $\begin{array}{l}- \\
- \\
- \\
- \\
- \\
.38^{* * *}\end{array}$ \\
\hline Adj & $\mathbf{R}^{2}$ Change & .36 & .12 & .10 & .16 \\
\hline Tot & al Adj $R^{2}$ & .43 & .15 & .12 & .16 \\
\hline
\end{tabular}

1) $0=$ community nurse auxiliary, $1=$ community nurse

2) $0=$ male, $1=$ fernale

" $p \leq .05, * p \leq .01, \cdots p \leq .001$

Job satisfaction was related to the type of nurse and hours of employment: community nurses were less satisfied than auxiliaries and those who were employed for more hours are less satisfied with their work. These variables explain $7 \%$ of the variance. In addition to these control variables several job characteristics were related to job satisfaction as well: growth at work, feedback, task clarity and skill variety. The percentage explained variance by all the variables is moderately high (43\%). If the data are analyzed for the two types of nurse separately, no significant differences were found. In interpreting the regression analysis for burnout, it is important to recall that high burnout was reflected in high scores in emotional exhaustion and depersonalization and in low scores in personal accomplishment. Three control variables affect burnout: community nurses experience more depersonalization and nurses who are older and work more hours are more emotionally exhausted. Several job characteristics also affect burnout: 
pressure of time increases feelings of burnout, whereas autonomy, skill variety and task significance reduce feelings of burnout. Compared with job satisfaction the job characteristics explain less of the variance in the models with the burnout-dimensions (between $12 \%$ and $16 \%$ ). Separate analysis did not yield significant differences in related job characteristics between the two types of nurse.

\subsubsection{Effects of individual characteristics on job satisfaction and burnout}

The results of regression analysis with individual characteristics as independent variables are presented in table 4.

Table 4 Results of regression analysis for job satisfaction and burnout with individual characteristics as independent variables among the total group $(n=402)$

\begin{tabular}{llll}
$\begin{array}{l}\text { Job } \\
\text { satisfaction }\end{array}$ & $\begin{array}{l}\text { Emotional } \\
\text { exhaustion }\end{array}$ & $\begin{array}{l}\text { Depersona- } \\
\text { lization }\end{array}$ & $\begin{array}{l}\text { Personal } \\
\text { accomplishment }\end{array}$ \\
\hline
\end{tabular}

1) Control variables:

type of nurse ${ }^{1)}-.14^{*}$

age

$\operatorname{sex}^{2)}$

hours of employment

$\begin{array}{llll}-.14^{* *} & - & .13^{*} & -.11^{*} \\ -- & - & -.12^{*} & - \\ - & - & - & - \\ - & .20^{* * *} & .12^{*} & -\end{array}$

Adj $R^{2}$ Change

.06

.05

.02

00

2) Individual characteristics:

preference for career $\quad-.23^{*}$

preference for prestige $.17^{* *}$

preference for autonomy -

preference for co-operation -

preference for skill variety .16*

preference for lack of time

pressure

active approach

passive approach

seeking social support

support experienced

from head nurse

support experienced

from peers

(1)

\begin{tabular}{|c|c|c|c|}
\hline - & - & - & - \\
\hline - & $-.16^{* *}$ & - & $.31^{* *}$ \\
\hline- & $.28^{* \cdots *}$ & $.24^{n * * *}$ & $-.18^{* * *}$ \\
\hline & - & - & - \\
\hline $35^{* \pi * 4}$ & - & $-.11^{*}$ & $.16^{* 0 \times}$ \\
\hline $23^{*-k}$ & $-.21^{* * *}$ & - & - \\
\hline
\end{tabular}

Adj $R^{2}$ Change .25 .21 .16 .30

Total Adj $\mathbf{R}^{2}$ .31 .26 .18 .30

1) $0=$ community nurse auxiliary, $1=$ community nurse

2) $0=$ male, 1 = female

" $p \leq .05,{ }^{* *} p \leq .01,{ }^{\star * *} p \leq .001$ 
Looking at the effects of the control variables, the B's show that there are some differences compared with table 3 . Especially in terms of the three burnout-dimensions table 4 shows that the control variables more often reach the significance level. It shows that the effects of the control variables are dependent on the other variables in the model.

Several individual characteristics were related to job satisfaction. Persons who prefer prestige and skill variety are more satisfied, whereas preference for career has a negative influence on job satisfaction in community nursing. Further, social support experienced from the head nurse and peers has a positive influence on job satisfaction. Again, the percentage explained variance of the final model is moderately high (31\%) but less than the model with the job characteristics in table 3 . If regression analysis is done for the two types of nurse separately, some differences in the effects of the characteristics appeared. However, these differences proved not to be significant. In terms of burnout, almost all individual characteristics have an effect on one or more dimensions. Feelings of burnout are decreased by the following individual characteristics: preference for prestige, autonomy, cooperation and skill variety, an active approach to coping with problems and social support experienced from the head nurse and peers. Feelings of burnout are increased when a passive approach is used in coping with problems. The total Adjusted $R^{2}$ shows that in terms of burnout, the individual characteristics explain a lot more of the variance (between .18 and .30) than the job characteristics (between .12 and .16). If regression analysis is done for the two types of nurses separately and the B's are compared, it appears that in respect of all the three burnout-dimensions, the support experienced from the head nurse has significantly more effect for nurse auxiliaries than for nurses. The other differences between the B's were not significant.

Finally, the job characteristics and individual characteristics were included in one model. The results are presented in table 5 . The entering of characteristics was based on the Adjusted $R^{2}$ in tables 3 and 4 . The control variables were entered for all the four models in the first stage. Because job satisfaction was influenced to greater extent by job characteristics, all these characteristics were entered at the second stage and the individual characteristics that increased Adj $R^{2}$ significantly at the third stage. In terms of to the three burnout-dimensions, all the individual characteristics were entered in the second step followed by the job characteristics that changed the Adj $R^{2}$ significantly in the third step. Table 5 shows that most effects presented before remain and that the total explained variance of all the four models increases significantly through moderate to high percentages when job and individual characteristics are put together in one model. 
Table 5 The effects of job characteristics and individual characteristics on job satisfaction and burnout in one model

\begin{tabular}{|c|c|c|c|c|}
\hline & $\begin{array}{l}\text { Job } \\
\text { satisfaction ") }\end{array}$ & $\begin{array}{l}\text { Emotional } \\
\text { exhaustion 2) }\end{array}$ & $\begin{array}{l}\text { Depersona- } \\
\text { lization 2) }\end{array}$ & $\begin{array}{l}\text { Personal } \\
\text { accomplishment }{ }^{2)}\end{array}$ \\
\hline \multicolumn{5}{|l|}{ Control variables: } \\
\hline age & - & - & - & - \\
\hline $\operatorname{sex}^{4}$ & - & - & -- & - \\
\hline hours of employment & $-.10^{*}$ & $.15^{\star \star}$ & $.11^{*}$ & - \\
\hline Adj $R^{2}$ Change & .05 & .04 & .02 & .00 \\
\hline \multicolumn{5}{|l|}{ Job characteristics: } \\
\hline time pressure & $-.11^{*}$ & $.21^{*+* *}$ & - & $\ldots$ \\
\hline autonomy & - & $-.14^{\star \star}$ & $-.16^{\star \star}$ & $.15^{\star \star}$ \\
\hline task clarity & - & - & - & - \\
\hline skill variety & $.13^{*}$ & $-.13^{*}$ & - & - \\
\hline growth at work & $.24^{m \neq m}$ & $-.15^{\star \star}$ & - & - \\
\hline feedback & $.20^{\text {nam }}$ & - & - & - \\
\hline task significance & $.11^{*}$ & - & $-.15^{\star \star}$ & $.26^{* n *}$ \\
\hline
\end{tabular}

Adj $R^{2}$ Change

.32

.12

.04

.08

Individual characteristics:

preference for career

preference for prestige

preference for autonomy

preference for co-operation -

preference for skill variety $.12^{*}$

$\begin{array}{llll}-.16^{* * * *} & - & - & - \\ - & - & - & - \\ - & - & -.16^{* *} & - \\ -.12^{* *} & - & -.17^{* *} & - \\ - & -.17^{* *} & - & .12^{*} \\ - & .11^{*} & - & - \\ - & -.17^{* *} & - & .25^{* * *} \\ - & .25^{* * *} & .24^{* * *} & -.15^{* *} \\ .27^{* * *} & - & - & - \\ .13^{* *} & - & -.11^{*} & .13^{* *}\end{array}$

preference for lack of

time pressure

active approach

passive approach

seeking social support

support experienced

from head nurse

support experienced

from peers

$.13^{\circ}$

.17

.19

.17

.29

Adj $\mathbf{R}^{2}$ Change

.54

.35

.23

.37

1) at the first stage all the control variables were entered, at the second stage all the job characteristics and at the third stage the method 'fonward' was used to select the individual characteristics that increased Adj $\mathbf{R}^{2}$ significantly

2) at the first stage all the control variables were entered, at the second stage all the individual characteristics and at the third stage the method 'forward' was used to select the job characteristics that increased Adj $\mathbf{R}^{2}$ significantly

J) $0=$ community nurse auxiliary, $1=$ community nurse

4) $0=$ male, 1 = female

" $p \leq .05, " p \leq .01, \cdots p \leq .001$ 


\subsection{Discussion}

The data presented in this chapter show that there are several significant differences in job and individual characteristics between community nurses and community nurse auxiliaries. These differences show on the one hand that the content of the work of community nurses is more attractive (they have higher scores on skill variety and task identity) but on the other hand nurses feel themselves more often on their own (they experience more time pressure, they get less feedback and they experience less support from their head nurse). Because the Dutch Nursing Profile (National Council for Health Care, 1988) notes that assessment and diagnostics are reserved for nurses, it is not surprisingly that nurse auxiliaries score low on the variable 'task identity'. In respect of feedback the difference can be explained by the decreased involvement of head nurses in community nursing practice and the difference in responsibility between nurses and auxiliaries. Community nurses receive few feedback from their supervisor whereas nurse auxiliaries can always receive feedback from the nurses. Because of their broader area of responsibility it is part of community nurses' job to supervise and give feedback to community nurse auxiliaries. In addition to less feedback (a job characteristic) the community nurses also experienced less social support from their head nurse (an individual characteristic). In other words, when compared with auxiliaries, community nurses are less satisfied with the content of feedback they receive from their head nurse.

The scores on job satisfaction showed that nurses and nurse auxiliaries in community nursing are moderately satisfied with their job. These scores are comparably with the results of a study among nurses working in Dutch hospitals (Boumans, 1990) and in community nursing in the United Kingdom (McGrath et al., 1989; Wade, 1993). When the nurses and auxiliaries are compared the results showed that community nurses are less satisfied with their work in general, their head nurse, clarity and opportunities for growth at work. Furthermore, community nurses manifest more feelings of burnout. The difference in satisfaction between the two types of nurse is consistent with the result of the meta-analysis of Blegen (1993) that nurses with a higher level of education are less satisfied with their work. The lower scores on job satisfaction and more feelings of burnout among community nurses reflect an important issue that is under discussion in Dutch community nursing. Since practice shows that most patients ask for basic care requiring basic expertise that can be delivered by community nurse auxiliaries. However, most agencies still employ more community nurses than community nurse auxiliaries. Consequently the community nurses perform a lot of tasks below their level of training and skill and it is not always obvious when the specific expertise of a nurse is required (Jansen \& Kerkstra, 1993). 
Several job characteristics were shown to be related to job satisfaction and burnout. Job satisfaction is positively effected by task clarity, skill variety. possibilities for growth and feedback at work. These effects are consistent with other studies (e.g. Boumans, 1990; Blegen, 1993). When compared with the differences in job characteristics, it seems that the difference in job satisfaction is caused by the fact that nurses receive less feedback than auxiliaries. Although nurses do have more variety in their work, this characteristic is apparently less important for job satisfaction.

In our study autonomy was not significantly related to job satisfaction. The reason for this could be the fact that nurses working in the community are relatively autonomous and thus this characteristic is not so important for job satisfaction. This explanation is supported by the study of Parahoo \& Barr (1994): autonomy. was listed by only 8 of the 35 community nurses as factor that contributes to job satisfaction.

As regards burnout it became obvious that time pressure increases feelings of burnout, whereas burnout is decreased by autonomy, skill variety, growth at work and task significance. The effect of time pressure and autonomy is supported by other studies (Siefert et al., 1991; De Jonge et al., 1994). If the differences in mean scores on these characteristics are taken into account, it seems that the higher feelings of burnout among nurses can be explained by the greater pressure of time they are under. Further analysis between nurses and auxiliaries did not show differences in the effects of job characteristics for job satisfaction and burnout.

Job satisfaction and burnout is also determined by individual characteristics. With exception of preference for career and a passive approach to coping with problems, all the individual characteristics have a positive influence on job satisfaction and decrease feelings of burnout. The social support experienced at work in particular is important in increasing job satisfaction and decreasing burnout. The effect of the coping-strategy is consistent with the studies of Hare et al. (1988), Boyle et al. (1991) and the importance of social support experienced at work is supported by the studies of Hare et al. (1988), McGrath et al. (1989), Boumans (1990) and Boyle et al. (1991). The greater feelings of burnout among community nurses seem to be the consequence of the fact that they feel themselves less supported by their head nurse. Further analysis showed that the support experienced from the head nurse in case of burnout was more important for nurse auxiliaries than for community nurses.

Finally, the results of regression analysis showed that job satisfaction is affected to greater extent by job characteristics, whereas burnout is more a result of individual characteristics. This is relevant in respect of the changes in home health care. As a result of projected demographic changes, the 
changing demands of health care services and the need for the cost-effective use of resources have mapped a new course for the development of the profession (Gibbs et al., 1991). On the one hand the past decade has witnessed an increase in the employment of specialized nurses in primary health care to make more complex nursing care at home possible (RiportellaMuller et al., 1991; Bergen, 1991; Haste \& MacDonald, 1992; Jansen \& Kerkstra, 1993; Moons et al., 1994; Griffiths \& Luker, 1994; Wilson-Barnett \& Beech, 1994). On the other hand, special attention is paid to skill mix or differentiated practice: the restructuring of roles and functions of nurses according to education, experience, and competence (Gibbs et al., 1991; American Organization of Nurse Executives, 1990; Martin \& McGuire, 1990; Cowley, 1993; Jansen \& Kerkstra, 1993; Heath, 1994). These changes will have consequences for the job characteristics in community nursing and consequently affect job satisfaction and burnout. These changes give opportunities for making their work more enjoyable, especially to community nurses. It is hypothesized on the results in this chapter, that these changes at work will mainly have consequences for job satisfaction. If agencies want to decrease feelings of burnout it is more effective to pay attention to supervisory support, peer relationships and individual training-programmes instead of changing the work-content. The results of this study may be helpful in coping with the changes in community nursing. 


\subsection{References}

Algera JA. (1981). Kenmerken van werk (Job characteristics). PhD thesis. Lisse: Swets \& Zeitlinger

Algera J.A., Flier H. van der \& Kamp L.J.Th. van der (1986). Causal modeling of quality of work. In: The Psychology of Work and Organization (Debus G. \& Schroiff H.W.) (pp. 175 - 182). Amsterdam: Elsevier Science Publishers.

American Organization of Nurse Executives (1990). Cument issues and perspectives on differentiated practice. Chicago: American Hospital Association.

Bergen A. (1991). Nurses caring for the terminally ill in the community: a review of the literature. International Journal of Nursing Studies 28(1), 89-101.

Bergers G.P.A., Marcelissen F.G.H. \& Wolf Ch.J. de (1986). VOS-D Vragenlijst Organisatiestress- $D$, Handleiding (VOS-D Questionnaire Organization-stress- $D$, Manual). Stressgroep publikatie 36 .

Blegen M.A. (1993). Nurses' job satisfaction: a meta-analysis of related variables. Nursing Research 42(1), 36-41.

Boswell C.A. (1992). Work stress and job satisfaction for the community health nurse. Joumal of Community health nursing 9(4), 221-227.

Boumans N.P.G. (1990). Het werk van verpleegkundigen in algemene ziekenhuizen: een onderzoek naar werkaspecten en hun invloed op verpleegkundigen (The work of nurses in hospitals: a study about job characteristics and their effects on nurses). Maastricht: Rijksuniversiteit Limburg.

Boyle A., Grap M.J., Younger J. \& Thornby D. (1991). Personality hardiness, ways of coping, social support and burnout in critical care nurses. Joumal of Advanced Nursing 16, 850-857.

Cohen-Mansfield J. (1989). Sources of satisfaction and stress in nursing home caregivers: preliminary results. Joumal of Actvanced Nursing 14, 383-388.

Cowley S. (1993). Skill mix: value for whom? Health Visitor 66(5), 166-168.

Curreri C.A., Gilley W.F., Faulk L. \& Swansburg R.C. (1985). Job satisfaction: hospital-based RNs versus home health care RNs. Nursing Forum 22(4), 125-134.

Gibbs I., McCaughan D. \& Griffiths M. (1991). Skill mix in nursing: a selective review of the literature. Journal of Advanced Nursing 16, 242-249.

Griffiths J. \& Luker K. (1994). Community nurse attitudes to the clinical nurse specialist. Nursing Times 90(17) 39-42.

Hackman J.R. \& Oldham G.R. (1980). Work redesign. Massachusetts: Addison-Wesley Publishing Company, Inc.

Handy J.A. (1988). Theoretical and methodological problems within occupational stress and burnout research. Human Relations 41(5), 351-369.

Hardy M.A. (1993). Regression with dummy variables. Sage University Paper series on Quantitative Application in the Social Sciences, 07-093. Newburry Park, CA: Sage.

Hare J., Pratt C.C. \& Andrews D. (1988). Predictors of burnout in professional and paraprofessional nurses working in hospitals and nursing homes. International Joumal of Nursing Studies 25(2), 105-115.

Haste F.H. \& MacDonald L.D. (1992). The iole of the specialist in community nursing: perceptions of specialist and district nurses. Intermational Joumal of Nursing Studies 29(1), $37-47$.

Heath I. (1994). Skill mix in primary care: should be used to match services to needs rather than to cut costs. British Medical Joumal 308, 993-994. 
Jansen P.G.M. \& Kerkstra A. (1993). Functiedifferentiatie binnen de thuiszorg. De functies van wijkverpleegkundige, wijkverpleagster en gezinsverzorgende nader omschreven (Differentiated practice and specialization in home care. The roles of the community nurse, community nurse auxiliary and home help in detail). Utrecht: NIVEL.

Johnson J.V. \& Hall E.M. (1988). Job Strain, work place social support, and cardiovascular disease: a cross-sectional study of a random sample of the Swedish working population. American Joumal of Public Health 78(10), 1336-1342.

Jonge J. de, Janssen P. \& Landeweerd A. (1994). Effecten van werkdruk, autonomie en sociale ondersteuning op de werkbeleving van verplegenden en verzorgenden (Effects of workload, autonomy and social support on work-experience of nurses and nurse auxiliaries). Verploegkunde (1), 17-26.

Karasek R.A. \& Theorell T. (1990). Healthy work: stress, productivity and the reconstruction of working life. New York: Basic Books.

Kenyon V., Smith E., Hefty L.V., Bell M.L., McNeil J. \& Martaus T. (1990). Clinical Competencies for Community Health Nursing. Public Health Nursing 7(1), 33-39.

Le Blanc P.M. (1994). De steun van de leiding. Een onderzoek naar het Leader Member Exchange model in de verpleging (Supervisory support. A study about the Leader Member Exchange modal in nursing). PhD-thesis. Amsterdam: Thesis Publishers.

Martin S.D. \& McGuire M. (1990). A clinical ladder for the community health-care setting. Joumal of Community health nursing 7(4), 189-197.

Maslach C. \& Jackson, S.E. (1986). MBI: Maslach Burnout Inventory; manual research edition. Palo Alto: Consulting Psychologists Press, Inc..

McGrath A., Reid N. \& Boore J. (1989). Occupational stress in nursing. International Joumal of Nursing Studies 26(4), 343-358.

Moons M., Kerkstra A. \& Biewenga T. (1994). Specialized home care for patients with AIDS: an experiment in Rotterdam, The Netherlands. Joumal of Advanced Nursing 19, 1132-1140.

Moore T.F. \& Simendinger E.A. (1982). Organizational burnout: is your hospital on fire? Dimensions of Health Service 59, 17-18.

National Council for Health Care (1988). Verploegkundig beroepsprofiel (Nursing Profile). Zoetermeer: National Council for Health Care.

Netherlands Central Bureau of Statistics (1990 and 1994). Vademecum of Health Statistics of The Netherlands. Voorburg/Heerlen: Netherlands Central Bureau of Statistics.

Parahoo K. \& Barr O. (1994). Job satisfaction of community nurses working with people with a mental handicap. Joumal of Advanced Nursing 20, 1046-1055.

Riordan J. (1991). Prestige: key to job satisfaction for community health nurses. Public Health Nursing 8(1), 59-64.

Riportella-Muller R., Selby M.L., Salmon M.E., Quade D. \& Legault C. (1991). Specialty Roles in Community Health Nursing: A National Survey of Educational Needs. Public Health Nursing B(2), 81-89.

Schaufeli W. \& Dierendonck D. van (1994). Burnout, een begrip gemeten. De Nederlandse versie van de Maslach Burnout Inventory (MBI-NL) (Burnout, measuring a concept. The Dutch version of the Maslach Burnout Inventory (MBI-NL). Gedrag \& Gezondheid 22(4), 153-171.

Schreurs P.J.G., Willige G. van de, Tellegen B. \& Brosschot J.F. (1988). De Utrochtse Coping Ljst: UCL-handleiding (The Utrecht Coping List: UCL-manual). Lisse: Zwets \& Zeitlinger.

Seymour E. \& Buscherhof J.R. (1991). Sources and consequences of satisfaction and dissatisfaction in nursing: findings from a national sample. Intemational Joumal of Nursing Studies 28(2), 109-124.

Siefert K., Jayaratne S. \& Chess W.A. (1991). Job satisfaction, burnout, and turnover in health care social workers. Health and social work 16(3), 193-202.

Sullivan P.J. (1993). Occupational stress in psychiatric nursing. Joumal of Advancod Nursing $\mathbf{1 8}$ 591-601. 
Taylor B. (1985). The effect of DRGs on home health care. New Jersey's experience suggests DRGs are increasing the need for home care for more acutely ill patients. Nursing Outlook 33(6), 288-289.

Turton P. (1984). Nurses working in the community. Nursing Times 5, 40-42.

Verheij R.A. \& Kerkstra A. (1992). Intemational Comparative Study of Community Nursing. Aldershot: Avebury.

Vorst-Thijssen A., Brink-Muinen A. van den \& Kerkstra A. (1990). Het werk van wijkverple日gkundigen en wijkziekenverzorgenden in Nederland (The work of community nurses and community nurse auxiliaries in The Netherlands). Utrecht: NIVEL.

Wade B.E. (1993). The job satisfaction of health visitors, district nurses and practice nurses working in areas served by four trusts: year 1. Joumal of Advanced Nursing 18, 992-1004.

Walcott-McQuigg J.A. \& Ervin N.E. (1992). Stressors in the workplace: community health nurses. Public Health Nursing 9(1), 65-71.

Wilson-Barnett J. \& Beech S. (1994). Evaluating the clinical nurse specialist. A review. International Joumal of Nursing Studies 31(6), 561-571. 


\section{PATIENT-ASSIGNMENT, AN IMPORTANT ELEMENT OF DIFFERENTIATED PRACTICE IN COMMUNITY NURSING: the difference between desirability and reality ${ }^{1}$}

\subsection{Summary}

In community nursing agencies two types of nurse are often employed; these are first and second level nurses. The difference in expertise between these two types of nurse is based on differences in educational preparation. In order to use this expertise to its best effect, it is important to assign the appropriate care-giver to the appropriate patient. In this chapter an instrument for patient-assignment in the Netherlands is described in terms of validity, reliability, clinical utility and acceptability. This instrument pays specific attention to the complexity of nursing situations, and the complexity of nursing care. Patients are assigned to either a first level nurse or a second level nurse based on a complexity-judgement. The results show that the instrument has acceptable levels of validity and reliability. It also transpires that staffing available via Dutch community nursing agencies does not match the complexity of community nursing situations. The results show a shortage of second level nurses and a surplus of first level nurses. Finally, it was clear that not all nurses appreciate the system of patient-assignment. Some found it difficult to explain why they classified some nursing situations as complex and others as non-complex. Others, however, valued the instrument as a method for assigning patients on a professional rather than a subjective basis.

\subsection{Introduction}

By means of concepts like 'differentiated practice' and 'skill mix', differentiation is made between the two types of nurse based on education, experience and competence (Primm, 1986, 1987, 1988, 1990; Koerner et al., 1989; Koerner, 1990; American Organization of Nurse Executives, 1990; Malloch et al., 1990; McClure, 1991; Hickey et al., 1991; Forsey et al., 1993). In spite of the presence of job profiles describing this differentiation this often does not emerge in nursing practice (see chapter 2 and Forsey et al., 1993). Therefore, to distinguish between the two types of nurse, in this chapter an

This chapter is an adapted version of the article Jansen P.G.M., Kerkstra A., Zee J. van der J., Huijer Abu-Saad H. Submitted. 
instrument is described that can be used for patient-assignment in community nursing.

In the study, community nursing is restricted to the care provided at home by professional home nursing agencies in the Netherlands. It includes rehabilitative, supportive, promotive or preventive and technical nursing care. The emphasis is mainly on the nursing of sick people at home. Other possible community nursing activities are not included, e.g. preventive mother and child care, psychiatric care, midwifery, school health nursing and occupational nursing. This can be compared to district nursing in the United Kingdom and home-care nursing in the United States of America. In Dutch community nursing, differentiation is made between community nurses (first level, comparable with the district nurse or graduate nurses) and community nurse auxiliaries (second level, comparable with the enrolled nurse or the diploma/associate nurse). This differentiation is in line with the Dutch 'Nursing Profile' and is based on education, responsibility and complexity of care (National Council for Health Care, 1988).

When nursing profiles are studied the basic distinction between the two levels of nursing centres on complexity of decision-making, structure of situation and/or setting (presence / absence of policies, procedures and protocols), and range of accountability for nursing care. First level nurses provide direct care to patients and their families with complex interactions of nursing diagnosis from pre-admission to post-discharge in structured and unstructured settings and situations. The second level nurse provides direct care to patients and members of a family with common, well-defined nursing diagnosis for a specified work period in structured settings and situations (Primm, 1986; National Council for Health Care, 1988; Malloch et al., 1990). Although 'complexity' is mentioned specifically in the job descriptions, this dimension has not generally been included in patient classification systems, except to the degree that more complex care is often positively related to time. However, the findings of the use of the Patient Intensity for Nursing Index (PINI) suggest that complexity of patient care needs are as important, or more so, to the consumption of nursing resources than are patients' dependency needs (Soeken \& Prescott, 1991). In other words, complexity of nursing care is important in assigning patients either to a community nurse or to a community nurse auxiliary. The development and use of an instrument for patient-assignment as assumed to be helpful in assigning the appropriate care-giver to the appropriate patient.

According to Corcoran (1986), complexity is determined by the number of problems presented by the patient, the interrelation of the problems, and the extent to which protocols could be applied. Verran \& Reid (1987) found that 
complexity was affected by the number of analyses that had to be performed, the variability of clients presenting to a clinic and the knowledge of a client (i.e. nurse's understanding). Nursing care is considered complex when the degree of routine, uniformity and predictability is low and special knowledge is necessary to deliver care. The critical determinant of complexity is the extent to which knowledge is required to effectively apply interventions in the delivery of nursing service (Verran \& Reid, 1987). Thus, complex nursing situations appeal to specific expertise and skills.

A review of the literature showed that in the Netherlands, the complexityconcept is more extensively used than it is in other countries. Different instruments have been developed in the Netherlands and are used in community nursing to determine whether nursing care is complex or not (Wijdeven, 1989; Nollen, 1990; Vrielink, 1990; Lapré \& Rutten, 1989; Hanrahan \& Lapré, 1990; Derckx et al., 1992; Van Amelsvoort et al., 1993; Mostert, 1993; Van Til et al., 1994). Because these instruments lack a theoretical framework, and do not always result in a clear patient-assignment Jansen \& Kerkstra $(1993,1995)$ developed a different instrument for patientassignment. The development and use of this new instrument is described in respect of the following research questions:

1. To what extent is the instrument for patient-assignment valid and reliable?

2. To what extent is the instrument for patient-assignment usable in community nursing (clinical utility)?

3. What is the experience of community nurses and community nurse auxiliaries with the use of the instrument for patient-assignment (acceptability)?

To answer these questions the results of two studies are presented. The first study describes the development of the instrument in terms of validity and reliability. Subsequently, the second study pays attention to the use of the instrument in nursing practice.

\subsection{Study 1: Reliability and validity of the instrument for patient-assignment}

In order to cover the total area of nursing, the instrument for patientassignment was built on a theoretical framework. The most suitable framework which provided the underpinning for developing the instrument is based on the work of Fawcett (1989). Fawcett analyzed several nursing models and concluded that considerable agreement exists about the central concepts of the discipline of nursing: health status (well and/or ill), person 
(recipient of nursing actions), environment (recipient's significant others and the setting), and nursing activities (Fawcett, 1989). In line with this framework, the instrument for patient-assignment contains these four concepts operationalized in several aspects. On the basis of a study of several existing instruments, aspects were selected and added that determine the complexity of nursing-situations. These aspects are presented in the first column in table 1 and categorized in the first three concepts of Fawcett (1989): health status, person and environment. Subsequently the fourth concept (nursing activities) is described in the second column. Specific nursing activities deemed to be appropriate could be selected based on an assessment of the health status, the person and the environment

Table 1 Aspects of the instrument for patient-assignment based on the complexity of nursingcare

\begin{tabular}{|c|c|}
\hline $\begin{array}{l}\text { Aspects that determine the complexity of } \\
\text { nursing-situations }\end{array}$ & Complex nursing interventions \\
\hline $\begin{array}{l}1 \text { Health status } \\
\text { a is the nursing diagnosis not well-defined? } \\
\text { b is the health status life threatening? } \\
\text { c are there many changes in patient's } \\
\text { health status? } \\
\text { d are the changes in patient's health status } \\
\text { unpredictable? }\end{array}$ & $\begin{array}{l}1 \text { Health stafus } \\
\text { a define a clear nursing diagnosis } \\
\text { b give terminal care to the patient } \\
\text { c observe/anticipate many changes in } \\
\text { health status } \\
\text { d observe/anticipate unpredictable } \\
\text { changes in health status }\end{array}$ \\
\hline $\begin{array}{l}2 \text { Person (recipient of nursing actions) } \\
\text { a does the patient lack the power to } \\
\text { communicate adequately? } \\
\text { b does the patient lack understanding of } \\
\text { his illness? } \\
\text { c does the patient lack motivation to } \\
\text { contribute towards recovery from the } \\
\text { illness? }\end{array}$ & $\begin{array}{l}2 \text { Person (recipient of nursing actions) } \\
\text { a observe / support adequate } \\
\text { communication } \\
\text { b support the patient in achieving an } \\
\text { understanding of the illness } \\
\text { c motivate the patient to contribute } \\
\text { towards recovery from the illness }\end{array}$ \\
\hline $\begin{array}{l}3 \text { Environment (recipient's significant } \\
\text { others the sefting) } \\
\text { a do the informal carers lack } \\
\text { understanding of patient's illness? } \\
\text { b are the informal carers mentally } \\
\text { strained? } \\
\text { c do the informal carers lack motivation to } \\
\text { contribute towards recovery from the } \\
\text { illness? } \\
\text { d is intensive co-operation with other } \\
\text { disciplines desirable? } \\
\text { e is the situation at home unsafe and/or } \\
\text { unacceptable for the patient? } \\
\text { f are resources present to carry out } \\
\text { specific technical nursing interventions? }\end{array}$ & $\begin{array}{l}3 \text { Environment (recipient's significant } \\
\text { others/the setting) } \\
\text { a support the informal carers in achieving } \\
\text { an understanding of the illness } \\
\text { b support informal carers mentally and } \\
\text { emotionally } \\
\text { c motivate the informal carers to contribute } \\
\text { towards recovery from the illness } \\
\text { d intensive co-operation with other } \\
\text { disciplines and/or co-ordination of the } \\
\text { total care-situation } \\
\text { e make the situation at home safe and/or } \\
\text { acceptable for the patient } \\
\text { f carry out specific technical nursing } \\
\text { interventions }\end{array}$ \\
\hline
\end{tabular}


The question that arises is why do just the aspects in the first column determine the complexity of nursing situations? The answer is, that if these aspects are present in a nursing situation, interventions are needed that require expertise in diagnostics, psycho-social support and specific technical nursing interventions. In terms of the definition of Verran \& Reid (1987), the degree of routine, uniformity and predictability is low, and specific knowledge is requested for these interventions. Consequently, the expertise of a nurse is needed. A nurse auxiliary is not trained to cope with this kind of situation.

The aspects and interventions presented in table 1 were included in the instrument for patient-assignment. In a nursing situation, all the questions in the first column have first to be answered by 'yes' or 'no'. These questions are: Is the nursing diagnosis not well-defined? Is the health status life threatening? Are there many changes in patient's health status? ... etc. In this way the total situation is analyzed systematically in respect of the presence of aspects that determine the complexity of nursing care. It prevents, for example, a patient suffering from dementia who requires help with bathing being automatically assigned to a nurse auxiliary without considering the informal carer (who finds it difficult to cope with the situation). In such a situation moral support to the informal carer is needed and the expertise of a nurse is required. On the other hand, a patient might be unmotivated and lacks understanding of his illness, whereas the informal carer might have understanding of the illness and be very motivated to contribute towards recovery. In such a situation, it is probably not necessary to support the patient in understanding his/her illness. Consequently, a nurse will not be needed, the expertise of a nurse auxiliary is adequate. These examples show that the complexity of nursing situations is based on the existence of a combination of several aspects; the whole is more than the sum of the parts.

When all the questions in the first column are answered by a yes or no, a decision is taken on the interventions required. In this respect, the nurse has to answer the following question in respect of each intervention: is the intervention an essential part of nursing care? The addition of 'an essential part' is used to stress that the intervention is explicitly designed in the plan of nursing care to reach a specific outcome. The answer to this question depends on a combination of all the aspects that are present. For example, a patient suffering from dementia requires help with bathing. Analysis of the environment makes obvious that her partner is not capable to cope with the situation. In such a situation, 'mental and emotional support of the informal carer' has probably to be part of nursing care. In the nursing care plan therefore, an outcome has to be formulated for this aspect and the question can be answered by a 'yes'. If at least one of the questions regarding the nursing interventions is answered by a 'yes' the nursing situation is judged as 
complex. In all other cases the situation is designated as non-complex. In terms of this judgement, the following nursing assignment is to be preferred: a community nurse in complex nursing situations and a community nurse auxiliary in non-complex situations.

\subsubsection{Method}

The content validity was established and is based on a study of several existing instruments, from which criteria were selected, added to and categorized using the concepts of Fawcett (1989). Subsequently, the instrument was assessed in a meeting of experts. During this meeting the instrument was judged by 25 experts (e.g. community nurses, community nurse auxiliaries, staff nurses, clinical nurse specialists, teachers of nursing). The experts decided that all the criteria selected were relevant in determining the complexity of nursing care. In addition, five written-up cases were discussed during the meeting and consensus was reached on judgements in terms of complexity: three cases were judged as complex and two as noncomplex.

To test the construct validity of the instrument the known-group method was used. This is defined as an analysis of the degree to which the instrument separates groups that are predicted to differ on the basis of some theory or known characteristic (Polit \& Hungler, 1987). In this study, 65 community nurses were asked to judge the complexity of the five written-up cases discussed at the meeting of experts. They had to judge all the cases without the instrument at first. Subsequently, they were allowed to open an envelope with all the information and instructions explaining how to use the instrument. In line with these instructions, they had to judge all the cases with the instrument. The judgements resulting from the meeting of experts were used as point of reference to decide to what extent the nurses judged complexsituations as complex and non-complex situations as non-complex (construct validity).

As regards the reliability of the instrument, attention was paid to the agreement between the nurses. The extent to which the 65 community nurses agreed about the presence of each aspect and intervention was determined for the five cases. When an agreement of $80 \%$ or more was achieved it was decided that reliability on this aspect or intervention was acceptable (interrater reliability).

\subsubsection{Results}

First the results on the reliability of the aspects and interventions in the instrument are presented (table 2). 
Table 2 Agreement of $80 \%$ or more about aspects of complexity and complex nursing interventions (percentages $\geq 80 \%$ are presented)

Aspects that determine complexity

$\begin{array}{llllll}\text { Case: } & \text { I II } & \text { III } & \text { IV } & \text { V }\end{array}$

1. Health status:

not well-defined nursing diagnosis

health status threatens the patient with death

many changes in patient's health status

unpredictable changes

$\begin{array}{ccccc}- & - & - & 86 & 89 \\ 100 & 97 & 98 & 90 & 100 \\ 98 & - & 86 & 92 & 97 \\ 92 & 81 & 80 & - & 84\end{array}$

2. Recipient of nursing actions:

patient lacks the power to communicate adequately

patient lacks understanding of his/her illness

patient lacks motivation to contribute towards

recovery

$\begin{array}{ccccc}89 & - & 86 & 100 & 100 \\ 94 & 87 & 81 & - & 97 \\ 95 & - & 95 & 94 & 100 \\ & & & & \\ 95 & 100 & 88 & - & 100 \\ - & 98 & 100 & - & 100 \\ 91 & 100 & 100 & - & 100 \\ - & - & - & 84 & 86 \\ - & 89 & 92 & 90 & 100 \\ 100 & 93 & 100 & 100 & 100\end{array}$

3. Environment (recipient's significant others):

informal carers lack understanding of patient's illness

informal carers are mentally strained

informal carers lack motivation to contribute towards

recovery

intensive co-operation with other disciplines is

desirable

situation at home is unsafe and/or unacceptable

resources are present to carry out specific technical

nursing interventions

4. Complex nursing interventions:

define a clear nursing diagnosis

give terminal care to the patient

observe / anticipate many changes in health status

observe / anticipate unpredictable changes in health

status

observe / support adequate communication

support patient in achieving understanding of the illness motivate patient to contribute towards recovery

from the illness

support informal carers to achieve understanding of

the illness

mental and emotional support of informal carers

motivate informal carers to contribute towards

recovery from illness

intensive co-operation with other disciplines and/or

co-ordination of the total care-situation

make the situation at home safe and/or acceptable

for the patient

carry out specific technical nursing interventions

\begin{tabular}{ccccc}
- & - & - & - & - \\
100 & 98 & 100 & 100 & 100 \\
93 & - & 84 & 92 & 90 \\
87 & 86 & - & - & - \\
- & - & 84 & 94 & 97 \\
89 & - & - & - & 92 \\
90 & - & 84 & - & 98 \\
97 & 92 & 92 & - & 100 \\
- & 87 & 97 & - & 100 \\
94 & 94 & 90 & - & 98 \\
- & - & - & 86 & 84 \\
- & 83 & 92 & 81 & 98 \\
98 & 100 & 100 & 100 & 82 \\
\hline
\end{tabular}

The results of this test showed that there is considerable agreement in describing the presence of aspects that determine the complexity of nursingsituations (i.e. health status, recipient of nursing actions and environment/ 
recipient's significant others). For most of these aspects an agreement of $80 \%$ or more was achieved.

There was less agreement about the extent to which the corresponding intervention had to be performed (i.e. complex nursing interventions). As described in the method section, nurses had to select these interventions by answering the question: is the intervention an essential part of the plan of nursing care, yes or no? From their comments it became obvious that it was difficult for the nurses to choose between only two alternatives in answering this question. They would like to have the opportunity to choose from more alternatives.

As regards the test of validity table 3 shows the results.

Table 3 Judgement of the complexity of five written cases with and without use of the instrument for patient assignment, in percentages

\begin{tabular}{llll}
\hline & $\begin{array}{l}\text { Judgement: } \\
\text { complex }\end{array}$ & not complex & unclear \\
\hline $\begin{array}{l}\text { Case I. (meant as complex) } \\
\text { without instrument } \\
\text { with instrument }\end{array}$ & 65 & 23 & 12 \\
$\begin{array}{l}\text { Case II. (meant as complex) } \\
\text { without instrument }\end{array}$ & 100 & - & - \\
with instrument & 77 & 17 & 6 \\
$\begin{array}{l}\text { Case III.(meant as complex) } \\
\text { without instrument } \\
\text { with instrument }\end{array}$ & 98 & 2 & - \\
$\begin{array}{l}\text { Case IV. (meant as not-complex) } \\
\text { without instrument } \\
\text { with instrument }\end{array}$ & 31 & 66 & - \\
$\begin{array}{l}\text { Case V. (meant as not-complex) } \\
\text { without instrument } \\
\text { with instrument }\end{array}$ & 94 & 6 & 5 \\
\hline
\end{tabular}

First, the results show that nurses judged the situations differently without or with the instrument. The nurses said that they had overlooked some aspects when they had not used the instrument. Secondly, the results show that the three nursing situations considered to be complex were also judged as complex using the instrument. Of the two nursing situations that were considered to be non-complex, one was judged as non-complex and one as complex. Thus, in one situation the judgement based on the instrument differed from the judgements the experts gave. The reason for this difference seemed to be the lack of information in the 'written' case. In this respect, nurses often judged the nursing diagnosis to be not well-defined, and consequently they felt a need for a more precise nursing diagnosis. 


\subsubsection{Conclusion}

Based on the findings above, it was concluded that the validity and reliability of the instrument was acceptable, but that the instrument could be improved by giving more options for assessing the nursing interventions. Accordingly, the instrument was altered by giving the nurses the opportunity to choose from four options as to the extent the intervention was part of nursing care:

(1) no part

(2) small part

(3) reasonable part

(4) important part the corresponding intervention is not performed in nursing care

the corresponding intervention needs no special attention, it is a common part of nursing care

the corresponding intervention needs a certain amount of attention, but is not essential in nursing care

the corresponding intervention is designed explicitly in the plan of nursing care to achieve a specific goal

If at least one intervention is an important part of nursing care, it means that complex nursing care has to be delivered. With these alterations the instrument was introduced in some agencies to study its clinical utility and acceptability (study 2). As it is possible that the real assignment differs from the judgement based on the instrument, the nurses also had to register the type of nurse actually assigned and the motives for this assignment.

\subsection{Study 2: Clinical utility and acceptability of the instrument for patient-assignment}

\subsubsection{Method}

The subjects in this study were 101 community nurses and 52 community nurse auxiliaries employed by three agencies for community nursing in different parts of the Netherlands. Within each agency, an experimental group and a comparison group was formed. In the experimental group the instrument described above for assignment was used from June 1994 through January 1995. As part of the assessment procedure, the instrument was filled in by a community nurse and included in the plan of nursing care. A community nurse or a community nurse-auxiliary was assigned to the patient on the basis of this instrument. In some other teams, (the comparison group) assignment was not based on the use of the instrument but on individual criteria and the considerations of the community nurse. These criteria may be different for each community nurse and are not always clear to everyone.

To study the difference in assignment between the experimental group and the comparison group, the nurses in the comparison group registered the type of nurse assigned to the patient and the reason the assignment was based 
on. The nurses and auxiliaries in the comparison group were not aware of the instrument used in the experimental group. The number of forms that were received and the participants in this study are described in table 4.

Table 4 Number of assignment-forms received from the experimental and comparison groups

\begin{tabular}{|c|c|c|c|c|}
\hline Agency & $\begin{array}{l}\text { Experimental group: } \\
\text { Number of forms }\end{array}$ & Participants & $\begin{array}{l}\text { Comparison group: } \\
\text { Number of forms }\end{array}$ & Participants \\
\hline 1 & 558 & $\begin{array}{l}38 \text { nurses } \\
22 \text { nurse-auxiliaries }\end{array}$ & 124 & $\begin{array}{l}14 \text { nurses } \\
9 \text { nurse-auxiliaries }\end{array}$ \\
\hline 2 & 471 & $\begin{array}{l}13 \text { nurses } \\
6 \text { nurse-auxiliaries }\end{array}$ & 173 & $\begin{array}{l}18 \text { nurses } \\
6 \text { nurse-auxiliaries }\end{array}$ \\
\hline 3 & 122 & $\begin{array}{l}9 \text { nurses } \\
2 \text { nurse-auxiliaries }\end{array}$ & 65 & $\begin{array}{l}9 \text { nurses } \\
7 \text { nurse-auxiliaries }\end{array}$ \\
\hline Total & 1151 & 90 & 362 & 63 \\
\hline
\end{tabular}

Table 4 shows that more forms were received from the experimental group than the comparison group. This is probably not due to there being fewer patients in the comparison group. The reason is probably the lack of commitment to the study; since the nurses and auxiliaries in the comparison group were not faced with changes, they performed their ictivities as usual. Consequently, the nurses and auxiliaries in the comparison group were less motivated to fill in the forms. This is illustrated by the point at which some nurses and auxiliaries in the comparison group asked for extra information about the use of the forms. Because of this the comparison between the experimental group and comparison group has to be handled with caution.

Finally, to acquire an idea of the use of the instrument in practice in all the agencies, a 'central-person' was appointed. The researcher contacted these persons regularly in 1994 (once per 1-2 months). These persons were interviewed for information about the implementation process using a semistructured questionnaire. Further, in each agency, one evaluation-meeting was organized with all the community nurses and nurse auxiliaries in the experimental group. In the period between November 1994 and January 1995, the researcher visited these meetings and took note of their experience with the instrument.

\subsubsection{Results}

The instrument for patient-assignment is described in some detail: the extent to which nursing situations are judged as complex and non-complex, the discrepancy between required assignment and real assignment, patientassignment as compared between the experimental and comparison group, and experience with the use of the instrument for patient-assignment. 
The extent to which nursing situations are judged as complex and noncomplex

Table 5 shows an overview of the extent to which several aspects that determine the complexity were present in the nursing situations. The figures show the extent to which the corresponding intervention is part of nursing care in these situations.

Table 5 Presence of aspects that determine the complexity of nursing-care and the extent to which the corresponding intervention is part of nursing care in the experimental group ( $n=1151)$

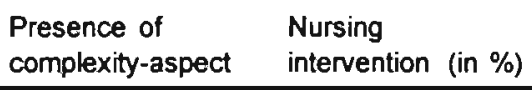

Aspects that determine the complexity of nursing-care

number $\%$

$(1)^{0)}(2)^{n)}$

$(3)^{n)}(4)^{n)}$

1. Health status:

the nursing diagnosis is not well-defined the health status is life-threatening

$\begin{array}{cccccc}218 & 19 & 8 & 6 & 41 & 45 \\ 218 & 19 & 12 & 17 & 29 & 42 \\ 471 & 41 & 1 & 9 & 50 & 40 \\ 571 & 50 & 2 & 12 & 45 & 41\end{array}$

there are many changes in patient's

health status

the changes in patient's health status

are unprodictable

2. Recipient of nursing actions:

the patient lacks the power to communicate

adequately

$\begin{array}{llllll}335 & 29 & 5 & 23 & 51 & 21\end{array}$

the patient lacks understanding of his/her

illness

the patient lacks motivation to contribute

towards recovery

$\begin{array}{llllll}429 & 37 & 7 & 27 & 39 & 27\end{array}$

$\begin{array}{llllll}195 & 17 & 7 & 22 & 42 & 29\end{array}$

3. Environment (recipient's significant others / the selting): informal carers lack understanding of patient's illness

informal carers are under mental stress

informal carers lack motivation to contribute towards recovery

intensive co-operation with other discipline

is desirable

\begin{tabular}{llllll}
161 & 14 & 9 & 29 & 38 & 24 \\
376 & 33 & 4 & 17 & 38 & 41 \\
72 & 6 & 22 & 36 & 21 & 21 \\
382 & 33 & 5 & 19 & 51 & 25 \\
166 & 14 & 5 & 16 & 47 & 32 \\
168 & 15 & 25 & 13 & 35 & 27 \\
\hline
\end{tabular}

the situation at home is unsafe and/or

unacceptable for the patient

resources are present to carry out specific

technical nursing interventions

7) the scores are to interpreted as follows:

(1) the corresponding intervention is not performed in nursing care

(2) the corresponding intervention needs no special attention, it is a common part of nursing care

(3) the corresponding intervention needs fairly much attention, but is not essential in nursing care

(4) the corresponding intervention is explicitly formulated in the plan of nursing care to achieve a specific goal 
An illustration is provided for the correct interpretation of the figures in table 5. The percentages of 'complexity-aspects present' relate to the total group (e.g. in $19 \%$ of the 1151 nursing-situations the nursing diagnosis was not-well defined). The percentages, in respect of the interventions, relate to the numbers in the same row (e.g. a "4" was scored on nursing diagnosis in $45 \%$ of the 218 nursing situations).

Table 5 shows that some aspects of complexity are more often present than others. In half of the situations the changes in health status are unpredictable, in $41 \%$ there are many changes and a third of the patients do not understand their illness; have informal carers who are under mental stress and desire intensive co-ordination with other disciplines. The aspect least often present is the lack of motivation by informal carers in contributing towards recovery from the illness $(6 \%)$. Table 5 shows that if an aspect is present, in most cases the corresponding intervention is a reasonable or important part of nursing care (the highest percentages are grouped under the scores 3 and 4).

Further analyses of the interventions showed that the following interventions are generally the reason for judging a nursing situation as complex:

- observation and anticipation of many and unpredictable changes in health status,

- intensive co-operation with other disciplines and/or co-ordination of the total care-situation,

- mental and emotional support by informal carers.

All the interventions that are less often present in nursing situations focus on the environment: support to achieve understanding of the illness by informal carers, motivation of informal carers for collaboration, making the situation at home safe and acceptable, and carrying out technical nursing interventions.

\section{Discrepancy between required assignment and real assignment}

After the description of the several aspects and interventions, attention is now paid to the type of nurse who is required and the nurse who is assigned. The community nurses judged $46 \%$ of all the nursing situations as complex. In these situations, a community nurse is the appropriate care-giver. The remaining $54 \%$ were judged as non-complex which means that a community nurse auxiliary is the appropriate care-giver. When the type of nurse assigned is viewed subsequently, it becomes obvious that $56 \%$ of the patients are assigned to a community nurse; $13 \%$ to a community nurse auxiliary and $25 \%$ are cared for by a community nurse and nurse auxiliary together. The assigned person in the remaining $6 \%$ is unknown. Thus there is a discrepancy between the required and assigned care-giver. Table 6 pays further attention to this discrepancy in respect of the type of illness and reason for assignment. 


\begin{tabular}{|c|c|c|c|}
\hline $\begin{array}{l}\text { Required } \\
\text { type of nurse }\end{array}$ & $\begin{array}{l}\text { Assigned } \\
\text { type of nurse }\end{array}$ & $\begin{array}{l}\text { Type } \\
\text { of illness }\end{array}$ & $\begin{array}{l}\text { Reason } \\
\text { for assignment ") }\end{array}$ \\
\hline \multirow[t]{4}{*}{$\begin{array}{l}\text { community nurse } \\
(n=530)\end{array}$} & $\begin{array}{l}65 \% \text { community nurse } \\
(n=341)\end{array}$ & $\begin{array}{l}38 \% \text { cancer } \\
11 \% \text { diabetes mellitus } \\
10 \% \text { mental illness }\end{array}$ & $\begin{array}{l}28 \% \text { education } \\
18 \% \text { experience } \\
11 \% \text { staffing } \\
5 \% \text { area of special } \\
\text { expertise }\end{array}$ \\
\hline & $\begin{array}{l}3 \% \text { community nurse } \\
\text { auxiliary }(n=16)\end{array}$ & $\begin{array}{l}25 \% \text { neurological } \\
\text { disorders } \\
19 \% \text { diabetes mellitus }\end{array}$ & $\begin{array}{l}38 \% \text { area of special } \\
\text { expertise } \\
31 \% \text { experience } \\
25 \% \text { education } \\
0 \% \text { staffing }\end{array}$ \\
\hline & $\begin{array}{l}28 \% \text { nurse and } \\
\text { and auxiliary together } \\
(n=150)\end{array}$ & $\begin{array}{l}18 \% \text { cancer } \\
16 \% \text { cardiac diseases } \\
11 \% \text { neurological } \\
\text { disorders }\end{array}$ & $\begin{array}{l}34 \% \text { experience } \\
26 \% \text { staffing } \\
10 \% \text { education } \\
6 \% \text { area of special } \\
\text { expertise }\end{array}$ \\
\hline & $4 \%$ unknown $(n=23)$ & & \\
\hline \multirow[t]{4}{*}{$\begin{array}{l}\text { community nurse } \\
\text { auxiliary ( } n=621)\end{array}$} & $\begin{array}{l}49 \% \text { community nurse } \\
(n=306)\end{array}$ & $\begin{array}{l}12 \% \text { cancer } \\
12 \% \text { cardiac diseases } \\
11 \% \text { CVA }\end{array}$ & $\begin{array}{l}74 \% \text { staffing } \\
5 \% \text { experience } \\
4 \% \text { area of special } \\
\text { expertise } \\
3 \% \text { education }\end{array}$ \\
\hline & $\begin{array}{l}22 \% \text { community nurse } \\
\text { auxiliary }(n=133)\end{array}$ & $\begin{array}{l}14 \% \text { cardiac diseases } \\
11 \% \text { diabetes mellitus } \\
11 \% \text { physical mobility }\end{array}$ & $\begin{array}{l}32 \% \text { education } \\
19 \% \text { expertise } \\
14 \% \text { staffing } \\
8 \% \text { area of special } \\
\text { expertise }\end{array}$ \\
\hline & $\begin{array}{l}22 \% \text { nurse and } \\
\text { auxiliary together } \\
(n=139)\end{array}$ & $\begin{array}{l}14 \% \text { physical mobility } \\
14 \% \text { decubitus ulcer } \\
12 \% \text { diabetes mellitus }\end{array}$ & $\begin{array}{l}61 \% \text { staffing } \\
12 \% \text { education } \\
6 \% \text { area of special } \\
\text { expertise } \\
4 \% \text { education }\end{array}$ \\
\hline & $7 \%$ unknown $(n=43)$ & & \\
\hline
\end{tabular}

a) for assignment several reasons could be given, sometimes no reason was given

b) some nurses and nurse auxiliaries have an 'area of special expertise', this means that they have specific expertise and skills regarding one or more patient categories

Comparison of the first two columns shows that in two thirds of the complex nursing situations a community nurse is assigned to the patient. Another $28 \%$ are assigned to both a nurse and an auxiliary. Assignment to a nurse auxiliary 
in these complex nursing situations, is mainly based on the specific experience of the auxiliary.

When a community nurse auxiliary is required, this type of nurse is assigned in only $22 \%$ of the cases. Almost half of these non-complex nursing situations are assigned to a community nurse. Staffing is the main reason for this. In other words, there are too many community nurses and too few community nurse auxiliaries employed by the agencies.

Patient-assignment, a comparison between the experimental and comparison group

In comparing the experimental and comparison group two characteristics are examined: the assigned care-giver and the reason for assignment. Before discussing the results in table 7 , it has to be noted that table 4 showed underregistration in the comparison group. As a result of this, the distribution of patient categories in the comparison group differed from the distribution in the experimental group. Because patient assignment is affected by the nature of the illness, the data of the comparison group was weighted in order to get the same distribution of patient categories as those in the experimental group. The Chi-square-test was carried out to analyze the differences between both groups.

Table 7 Comparison of patient-assignment between the experimental group and comparison group

Experimental group Comparison group

$(n=1151)$

$(n=362)$

assigned nurse:

community nurse

community nurse auxiliary

nurse and auxiliary together

unknown

\begin{tabular}{|c|c|}
\hline $51^{\cdots \cdots *}$ & 39 \\
\hline 15 & 15 \\
\hline $27^{ \pm+\pi+t}$ & $45^{\text {mat* }}$ \\
\hline 7 & 1 \\
\hline
\end{tabular}

reason for assignment:")

education

experience

staffing

area of special expertiseb)

\begin{tabular}{cc}
$36^{\star \star}$ & $45^{\star *}$ \\
$21^{\star *}$ & $27^{*}$ \\
$42^{*}$ & $34^{*}$ \\
6 & 9 \\
\hline
\end{tabular}

" $p \leq .05 ; * p \leq .01 ; * p \leq .001$

a) for assignment several reasons could be given, sometimes no reason was given

b) some nurses and nurse auxiliaries have an 'area of special expertise', this means that they have specific expertise and skills regarding one or more patient categories

When both groups are compared it becomes obvious that in the experimental group a community nurse was assigned to the patient more often; whereas in the comparison group, both a nurse and nurse auxiliary were assigned more often. This is not a result of difference in staffing as table 4 showed that the 
ratio 'nurse : nurse auxiliary' is comparable between the experimental and comparison group. Differences are also seen as regard to the reason for assignment. Within the experimental group care-givers are less frequently assigned based on education and experience; whereas staffing is often a reason for assignment. It seems that use of the instrument has made caregivers more aware that staffing is an important reason for an inappropriate care-giver being assigned to the patient.

\section{Experience with the use of the instrument for patient-assignment}

When the instrument was introduced in the experimental group many asked why they had to fill in this form because they already had to fill in so many other forms. Then, in the beginning it became obvious that it was not always easy to answer all the questions. It was not always easy for everyone to choose between the four options. The difference between score 3 and 4 in particular was not always obvious. However, after the nurses became used to the instrument they filled it in with more ease and became aware of the usefulness of the instrument. It was considered positive that the instrument gave insight in the reasons for assignment. Further, because nurses had sometimes different opinions on assignment interesting discussions followed in the teams.

This did not apply to all nurses and nurse auxiliaries. Some community nurses used the instrument only because they had to, and not as resource for patient assignment. One of the main reasons was that the workload made it difficult to find time to fill in the instrument. Others considered the instrument as threatening. They worried that the use of the instrument would have negative consequences for staffing, if a lot of situations were judged to be non-complex. They found it difficult and useless to fill in so many different forms for each patient. In their opinion it was at the cost of job satisfaction.

Finally, as regards the validity of the instrument, one aspect was missed by some nurses: psycho-social support for the patient. In their view, nursing situations often became complex when psycho-social support had to be given to the patient.

\subsection{Discussion}

To utilize nursing personnel more effectively, an instrument for patient assignment in community nursing was described. The instrument was developed on the basis of several existing instruments and the theoretical framework of Fawcett (1989). The validity and reliability of the instrument were tested and have been shown to be acceptable. This was illustrated by the comments made during the evaluation meetings with the exception of one complexity-aspect. Some nurses stressed that nursing situations often 
became complex, when psychosocial support was provided to the patient. As social support plays an important part in the care of the chronically ill at home (for example), it is necessary to include this aspect in the instrument (as part of the second concept: recipient of nursing actions).

As regards the clinical utility, the results showed that the instrument can be used to judge nursing situations in terms of complexity and patientassignment. An important result of this study is the finding that staffing does not match the complexity of nursing situations. The instrument showed that a majority of the nursing situations was judged as non-complex. In these situations a community nurse auxiliary (i.e. second level nurse) is needed. However, in most agencies for community nursing, there are more community nurses (i.e. first level nurses) than nurse auxiliaries. Thus, this finding shows a shortage of the number of community nurse auxiliaries and an overabundance of community nurses. Besides, it seems that use of the instrument has made care-givers more aware that staffing is an important reason for an inappropriate care-giver being assigned to the patient.

As regards the acceptability, some nurses and nurse auxiliaries expressed negative feelings about the use of the instrument in nursing practice. They found it difficult to justify why they judged some nursing situations as complex and others as non-complex. They also saw it as a viciation of the working methods they were used to. Other nurses, however, appreciated the fact that the instrument clarified patient assignment and encouraged discussion of it.

In interpreting the results it is important to know that up to a few years ago Dutch agencies for community nursing had to meet certain 'requirements of acknowledgement'. One of these requirements was the ratio of 3 community nurses to 1 community nurse auxiliary. Undoubtedly, the present ratio is a consequence of this and can not be changed immediately.

However, the results obviously showed that it is useful to analyze patient demand in terms of complex nursing interventions now and in the future. Consequently, by using an objective instrument for patient assignment, managers of the agencies for community nursing can get a better picture of the ratio needed between first and second level nurses.

As regards the community nurses and community nurse auxiliaries, the instrument encourages them to look at nursing situations in a professional way. What aspects of complexity are present in the situation; to what extent are corresponding interventions needed and which community nurse or community nurse auxiliary is the best to care for a particular patient. 


\subsection{References}

Amelsvoort F. van, Slingerland P. \& Verkaar E. (1993) Op kwaliteit aangesproken. Beslismodel voor de inzet van menskracht (Talking about quality. Model of decision for staffing). Utrecht: NIZW.

American Organization of Nurse Executives (1990). Current issues and perspectives on differentiated practice. Chicago: American Hospital Association.

Derckx E., Hollands L. \& Halfens R. (1993). Complexiteit van verpleegsituaties. Een meetinstrument voor de wijkverpleging (Complexity of nursing situations. A measuring instrument for community nursing). Tijdschrift voor Verpleogkundigen 24(23), 773-779.

Fawcett J. (1989). Analysis and evaluation of conceptual models of nursing. Philadelphia: F.A. Davis.

Forsey L.M., Cleland V.S. \& Miller B. (1993). Job descriptions for differentiated nursing practice and differentiated pay. The Joumal of Nursing Administration 23(5), 33-40.

Hanrahan M.H. \& Lapré F. (1990). Project wijkziekenverzorgenden. Deskundigheden verdeeld (Project community nurse auxiliaries. Expertises divided). Bunnik: Landelijke Vereniging voor Thuiszorg.

Hickey M., Billings D.M., Disch J., Eagleton B., Carty Farrell M., Turzan L. \& Vitello J.M. (1991). Competence statements for differentiated nursing practice in critical care. Focus on critical care 18(4), 286-293.

Jansen P.G.M. \& Kerkstra A. (1993). Functiedifferentiatie binnen de thuiszorg. De functies van wijkverpleogkundige, wijkverpleogster en gezinsverzorgende nader omschreven (Differentiated practice and specialization in home care. The roles of the community nurse, community nurse auxiliary and home help in detail). Utrecht: NIVEL.

Jansen P.G.M. \& Kerkstra A. (1995). Effecten van functiedifferentiatie binnen de thuiszorg, (Effocts of differentiatod practice and spocialization in community nursing) (pp. 49-62). Utrecht: NIVEL.

Koemer J.E. (1990). The relevance of differentiated practice in today's environment. In: Current issues and perspectives on differentiated practice (pp. 35-51). Chicago: American Organization of Nurse Executives.

Koerner J.E., Birch Bunkers L., Nelson B. \& Santema K. (1989). Implementing differentiated practice: the Sioux Valley hospital experience. The Joumal of Nursing Administration 19(2), 13-20.

Lapré F. \& Rutten J. (1989). Patiêntentoewijzing. Eerste en tweede deskundigheidsniveau in de wijkverpleging (Patient-assignment. First level and second level of expertise in community nursing). Tijdschrit voor Verploogkundigen 43(11), 352-354.

Mailoch K.M., Milton D.A. \& Jobes M.O. (1990). A model for differentiated nursing practice. The Joumal of Nursing Administration 20(2), 20-26.

McClure M.L. (1991). Differentiated nursing practice: concepts and consideration. Nursing Outrook 39(3), 106-110.

Mostert H. (1993). De complexiteit van de verplegsituatie. Op zoek naar een meetinstrument (Complexity of the nursing situation. Look for a measuring instrument). Tijdschrift voor Verpleogkundigen (12), 408-413.

National Council for Health Care (1988). Verpleegkundig beroepsprofiel (Nursing profile). Zoetermeer: National Council for Health Care.

Nollen C.L.M. Zorgkwaliteit van twoe deskundigheidsniveaus binnen complexe verploogsituaties in de wijkverpleging (Quality of care by two levels of expertise in complex nursing situations in community nursing). Maastricht: Rijksuniversiteit Limburg.

Polit D.F. \& Hungler B.P. (1987). Nursing research. Philadelphia: J.B. Lippincott Company.

Primm P.L. (1986). Entry into practice: competency statements for BSNs and ADNs. Nursing Outhok 34(3), 135-137. 
Primm P.L. (1987). Differentiated Practice for ADN- and BSN-Prepared Nurses. Joumal of Professional Nursing 4, 218-225.

Primm P.L. (1988). Implementation of differentiated practice through differentiated case management. Michigan Nurse (9), 33.

Primm P.L. (1990). Approaches and strategies. In: Current issues and perspectives on differentiated practice (pp. 17-34). Chicago: American Organization of Nurse Executives.

Soeken K.L. \& Prescott P.A. (1991). Patient intensity for nursing index: the measurement model. Research in Nursing \& Health 14, 297-304.

Til C. van, Halfens R. \& Hollands L. (1994). Deskundigheidsniveaus: gerelateerd aan complexiteit van wijkverpleegkundige zorg (Levels of expertise: correlation with complexity of nursing care). Verpleogkunde (1), 28-38.

Verran J.A. \& Reid P.J. (1987). Replicated testing of the nursing technology model. Nursing Research 36(3), 190-194.

Vrielink H. (1990). Deskundigheid op maat. Beleidsnote $1 \theta$ en $2 \theta$ deskundigheidsniveau (The right expertise. Policy-document first and second level of expertise). Amsterdam: Stichting Amsterdams Kruiswerk.

Wijdeven C. (1989). Partners op verschillend niveau (Partners on different levels). Maastricht: Rijksuniversiteit Limburg. 


\section{OUTCOMES OF DIFFERENTIATED PRACTICE AND SPECIALIZATION ON JOB CHARACTERISTICS, JOB SATISFACTION AND BURNOUT IN COMMUNITY NURSING}

\subsection{Summary}

In order to create a rich skill mix of qualified staff in community nursing in the Netherlands, two principles of work-(re)design are used: differentiated practice and specialization. This study describes the effects of these interventions on changes in job characteristics, job satisfaction and burnout. A pre-test posttest design was used. At first, it became obvious that most agencies needed more preparation than expected to implement differentiated practice and specialization in nursing practice. Secondly, implementation of differentiated practice showed two negative effects: second level nurses experienced less variety in their job, and first level nurses became less satisfied with growth at work. The effects of specialization showed to be more positive. It leads to less time pressure, more growth at work, more feedback and higher levels of job satisfaction. With respect to burnout no significant changes were found caused by work-redesign.

\subsection{Introduction}

Review of the literature (McKenna, 1995) showed that a rich skill mix of qualified staff is a highly efficient and highly effective way to run a health service. It leads among others to reduced costs, reduced complications, increased patient satisfaction, increased productivity, reduced staff absenteeism and reduced staff turnover (McKenna, 1995). In order to create a rich skill mix of qualified staff in community nursing in the Netherlands, two principles of work-(re)design are used: differentiated practice and specialization. Differentiated practice is a personnel deployment model in which the roles of nurses are (re)defined based on education, experience and competence (Murphy \& DeBack, 1990). Specialization concerns the way in which specialized knowledge is available in the community in order to meet the changed and complicated demands of home care. This chapter describes to what extent job characteristics, job satisfaction and burnout change among community nurses and community nurse auxiliaries when differentiated

1 This chapter is an adapted version of the article Jansen P.G.M., Kerkstra A., Zee J. van der, Huijer Abu-Saad H. Submitted. 
practice or specialization is implemented. Because the implementation of both differentiated practice and specialization was analyzed in one study it was possible to compare the outcomes of two different types of work-(re)design.

The term community nursing in this study is restricted to the care provided at home by professional home nursing agencies. It includes rehabilitative, supportive, promotive or preventive and technical nursing care. The emphasis is mainly on the nursing of sick people at home. Other possible community nursing activities are not included, e.g. preventive mother and child care, psychiatric care, midwifery, school health nursing and occupational nursing. This is comparable to district nursing in the United Kingdom.

Differentiated practice is a concept used to differentiate between two nursing roles based on education, experience and competence (Primm, 1986, 1987, 1988, 1990; Koerner et al., 1989; Koerner, 1990; American Organization of Nurse Executives, 1990; Malloch et al., 1990; McClure, 1991; Hickey et al., 1991; Forsey et al., 1993). To utilize available nursing personnel more effectively, differentiated practice is applied. Based on the premise that individual practitioners with different types of education, competence, and experience should not be used interchangeably, differentiated practice seeks to ensure that the work of nurses is carried out by the most appropriate nurse in the most appropriate way (Boston, 1990). The basic distinctions between the two roles in respect of differentiated practice centre on complexity of decision-making, range of responsibilities, and structure of situation and/or setting. The first level nurse (community nurse, i.e. registered nurse) provides direct care to patients and their families with complex interactions of nursing diagnoses from pre-admission to post-discharge in structured and unstructured settings and situations. The second level nurse (community nurse auxiliaries, i.e. enrolled nurse) provides direct care to patients and members of a family with common, well-defined nursing diagnoses for a specified work period in structured settings and situations (Primm, 1986; Malloch et al., 1990).

In the Netherlands specialized knowledge and skills are available by both the employment of Clinical Nurse Specialists (e.g. Wiegers, 1992; Kiers, 1993; Moons et al., 1994) and by means of the construction of 'areas-of-specialexpertise' for community nurses and community nurse auxiliaries. Clinical Nurse Specialists have been educated on a higher level (a post highervocational-training or the university) compared to the nurses with an area-ofspecial-expertise (who got specialized by training in practice). In this chapter the Clinical Nurse Specialists will not be discussed because this study focuses on the work of community nurses and community nurse auxiliaries. Therefore, attention is paid to the areas-of-special-expertise only. 
Areas-of-special-expertise are constructed mainly based on patient categories. These areas are constructed where specific knowledge is needed for the caring of a particular patient category, where a lot of treatment is possible or where many changes occur in a specific category. Examples of these areas are: patients with AIDS, diabetes mellitus, patients with chronic non specific lung diseases (CNSLD), patients with dementia, patients with rheumatism or patients who are incontinent. As regards one (or more) of these areas a community nurse (auxiliary) follows a course of study in this area ranging between few days to few months in length, keeps up to date with all the new developments, and attends continuing educational programs to stay abreast of trends and innovations on these issues. Subsequently, in her team and agency she can be consulted by her peers for knowledge or skills. In addition to this special expertise, the nurse performs the general tasks within community nursing (Wiegers, 1992; Jansen \& Kerkstra, 1993, 1995; Van Haaren, 1994; Ketelaars, 1996). In 1992, almost half of the Dutch agencies for community nursing had areas-of-special-expertise in use, and about one third intended to construct these areas for community nurses and community nurse auxiliaries (see chapter 2).

It seems that this type of specialization is congruent with developments in the United Kingdom. Two studies showed that district nurses expressed significantly more dissatisfaction than Clinical Nurse Specialists. These nurses reported that they would have preferred to carry out the work of the specialists themselves, but were prevented from doing so by heavy caseloads and lack of time. District nurses expressed the desire to become more knowledgeable in specialist areas (Haste \& MacDonald, 1992; Griffiths \& Luker, 1994).

Both differentiated practice and specialization are examples of work(re)design. The first concentrates on the specific differences between nursing roles whereas specialization focuses on the attractiveness of tasks within nursing roles. To study what consequences both circumstances have on community nurses and nurse auxiliaries, the research model presented in figure 1 was used. Based on a review of the literature (chapter 3 ) this research model was developed to study the outcomes of differentiated practice and specialization. 
Figure 1 Model to evaluate the effects of differentiated practica and specialization in community nursing

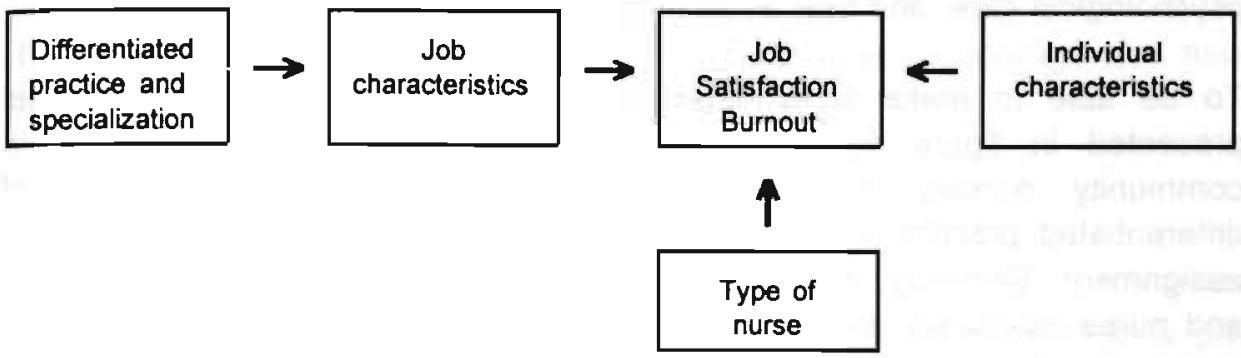

The research model suggests that some job characteristics (i.e. time pressure, autonomy, task clarity, skill variety, task identity, growth at work, feedback, task significance) change when differentiated practice or specialization is implemented. This will have consequences for the level of job satisfaction and burnout. But, because the outcomes are also influenced by individual characteristics, these have to be taken into account as well (i.e. biographical characteristics, preferences, coping strategies, and experienced social support). Finally, the vertical arrow in the model implies that the effects on job satisfaction and burnout can differ for different types of nurse.

In line with the research model this study seeks to address the following questions:

1. What job characteristics do change when differentiated practice or specialization is implemented in community nursing?

2. To what extent does implementation of differentiated practice or specialization affect job satisfaction and burnout among community nurses and community nurse auxiliaries?

Before presenting the method and results of this study, some hypotheses can be made based on the results of previous research and the content of workredesign. These hypotheses are formulated as 'expected outcomes'.

\subsubsection{Expected outcomes of differentiated practice}

A review of the literature (chapter 3 ) showed that only a few studies investigated the outcomes of differentiated practice (Hersterly et al, 1986; Koerner et al., 1989; American Organization of Nurse Executives, 1990; Malloch et al., 1990; Martin \& McGuire, 1990; Jung et al., 1994; Corley et al., 1994; Hutchens, 1994). All these studies focused on hospital nursing, and showed positive outcomes for first level nurses: they were more satisfied with their job because of a higher degree of challenge, variety and responsibility. These nurses could now practice 'what they were taught in school'. Second level nurses were less positive about differentiated practice. They felt they had lost something in their work because someone with another job status 
was practising beside them. In addition, Habes (1995) found that some experience differentiated practice as a subtle way of devaluating physical and psychological care, and over-evaluating knowledge.

To be able to make some hypotheses in line with the research model presented in figure 1, the essential parts of differentiated practice in community nursing are summarized. At first, an important part of differentiated practice is the use of job-profiles and an instrument for patient assignment. Secondly, the job-profiles describe that both community nurses and nurse auxiliaries are accountable for their own practice, but community nurses are also accountable for aspects of nursing care delegated to nurse auxiliaries. Thirdly, the nursing assessment, formulation of nursing diagnosis, patient assignment and co-ordination of care are restricted to community nurses, whereas community nurse auxiliaries are mainly engaged with the actual care given.

Based on the review of the literature and the models used to implement differentiated practice in community nursing, the following hypotheses are formulated:

1. Differentiated practice will lead to a higher degree of clarity about tasks and responsibilities.

2. Community nurse auxiliaries will experience a decrease in autonomy and skill variety.

3. Differentiated practice will lead to lower levels of job satisfaction and personal accomplishment for community nurse auxiliaries.

\subsubsection{Expected outcomes of specialization}

\section{(1.e. areas-of-special-expertise)}

Because the areas-of-special-expertise in the Netherlands are a relatively new concept scientific data are lacking. The only exception is the study by Van Bragt (1993) who found that nurses with an area-of-special-expertise gained more expertise in that area, but experienced a heavier workload. The nurses did not have enough time to carry out the tasks in their area.

These results do not make it easy to formulate hypotheses in terms of job characteristics, job satisfaction and burnout. But, together with the information given about the principle of areas-of-special-expertise, the following hypotheses are formulated:

4. Community nurses and community nurse auxiliaries with an area-ofspecial-expertise experience more time pressure, autonomy, skill variety, growth at work, and feedback at work. 
5. The areas-of-special-expertise will affect job satisfaction positively, especially as regards satisfaction with growth at work, and general work satisfaction.

6. The specialized community nurses and nurse auxiliaries will have higher feelings of personal accomplishment.

\subsection{Method}

To study the outcomes of differentiated practice and specialization a pretest/post-test quasi-experimental design was used. Within separate agencies for community nursing an experimental and comparison group were formed. In one of these groups differentiated practice or specialization (i.e. the intervention) was implemented (the experimental group) whereas other nurses and nurse auxiliaries performed their duties as they were used to (the comparison group). As regards differentiated practice there was a strict separation between experimental and comparison group: based on pragmatic grounds some teams were chosen to form the experimental group and other (comparable) teams the comparison group, whereby the somparison group was not abreast of the work method used in the comparison group. As regards specialization the experimental group was composed by community nurses and nurse auxiliaries who were capable to work with an area-ofspecial-expertise (i.e. selection based on e.g. motivation, hours of employment and experience). This means that it was impossible to make a strict separation between experimental and comparison group: specialized and non-specialized nurses worked together in one team.

Before differentiated practice and specialization was implemented, and a year later both groups filled in a questionnaire. In this paragraph attention is paid to the content of the interventions, the characteristics of the respondents and the measuring instruments that were used.

\subsubsection{Intervention}

\section{Differentiated practice}

Three agencies for community nursing participated in this study concerning differentiated practice. These agencies were selected at the end of 1993 and were intended to start with differentiated practice at the beginning of 1994 . Because of this it was possible to form in each agency an experimental group and a comparison group. The intervention consisted of two parts: the introduction of job profiles and the use of an instrument for patient assignment.

As regards the job profiles in all agencies the Dutch Nursing Profile (National Council for Health Care, 1988) was seen as starting-point for a differentiation 
between community nurses and community nurse auxiliaries. In line with this the community nurse is accountable for patient assignment and all stages of the nursing process. The community nurse auxiliary is accountable for nursing care he/she gives, contributes in the continuity of care and participates in the planning of nursing care. Both types of nurse work next to each other and are supervised by the head nurse.

The use of job profiles is an important part of differentiated practice. In one agency new profiles were introduced in the experimental group. The other two agencies had no new profiles but relied on job profiles that already existed in the agency.

Another important component of differentiated practice is the use of an instrument for patient assignment. In the experimental group of all the three agencies the instrument developed by the authors in a previous study was used. An extended description of this instrument is given in chapter 5 . Therefore, here only a global description is given. Based on an analysis of several nursing models by Fawcett (1989), a measure was developed in which criteria for complexity were divided into four categories: person (recipient of nursing actions), environment (recipient's significant others and the setting), health status (well and/or ill) and nursing interventions. Examples of criteria that determine the complexity are: the patient's unwillingness to cooperate (person), the number of disciplines involved in the care-situation (environment), the absence of informal carers able to cope with the situation (environment), the absence of well-defined nursing diagnoses (health), the number of changes in the patient's health-status and the requirement for specific technical nursing interventions. With this instrument the nursing situation is analyzed systematically. Based on this analysis it is decided to what extent complex nursing interventions need to be performed, and a judgement-of-complexity is given. If a patient needs complex nursing care a community nurse has to be assigned, not-complex nursing care can be performed by a community nurse auxiliary. Besides the complexity of nursing care other factors determine who is assigned to a patient (e.g. the educationI experience-level of the nurse or nurse auxiliary, or the availability of staff). Therefore these factors need to be integrated in the procedure of patient assignment.

In the experimental group the above described instrument for assignment was used from June 1994 till January 1995. After the assessment and formulation of the nursing diagnoses for each new patient in need of care, the instrument was filled in by a community nurse and included in the plan of nursing care. Based on this instrument a community nurse or a community nurse auxiliary was assigned to the patient. In the comparison group assignment was not based on the use of the instrument but on individual criteria and 
considerations of the community nurse. These criteria can be different for each nurse and are not always clear for everyone.

To study the difference in assignment between the experimental group and the comparison group, the community nurses of the comparison group registered for their patients which type of nurse was assigned to the patient and the reason assignment was based on. The nurses and nurse auxiliaries in the comparison group were not aware of the instrument used in the experimental group.

\section{Specialization}

Six other agencies for community nursing paid attention to specialization by means of the implementation of areas-of-special-expertise. These agencies were intended to start with this at the beginning of 1994. Within each agency an experimental group was formed by the community nurses and nurse auxiliaries with an area-of-special-expertise. Based on several criteria (e.g. motivation for specialization, hours of employment, experience) community nurses and community nurse auxiliaries were selected. The ones without such an area formed the comparison group. Areas-of-special-expertise were in most cases based on patient categories like chronic non specific lung diseases (CNSLD), oncology, diabetes mellitus, neurological disorders, stoma-care, psycho-geriatrics, incontinence and rheumatism. The first five areas fall in most agencies under the jurisdiction of community nurses whereas community nurse auxiliaries mainly concentrate on the last three. As regards an area-of-special-expertise several task activities had to be performed:

- follow a course of study in this areas,

- give advice, consultation and extra education to peers,

- give instruction about and (if necessary) perform specific technical nursing interventions,

- stay abreast of expertise and skills (e.g. by attending educational programs and visiting patients belonging to the area-of-specialexpertise),

- $\quad$ start with and/or keep up to date a relevant documentation-system, and

- participate in meetings with other community nurses and community nurse auxiliaries with the same area-of-special-expertise (group meetings led by clinical nurse specialists).

Although the agencies had the intention to start with the areas at the beginning of 1994, in practice it took longer to realize this kind of specialization. In most agencies only in autumn 1994 the areas got noticeable shape and content. Most attention was paid to education/training concerning the area, and making appointments about how to integrate the areas-ofspecial-expertise into nursing practice. At the end of 1994 only a few nurses and nurse auxiliaries had been consulted by peers. 
The comparison group differs from the experimental group by having no tasks regarding an area-of-special-expertise. Therefore, to keep informed by all the developments in nursing they had to develop initiatives by themselves, and had the possibility to consult a clinical nurse specialist or peers with an areaof-special-expertise (however, as described above, the latter hardly occurred).

\subsubsection{Sample}

Within all agencies for community nursing that participated in this study an experimental group and a comparison group was formed. At this rate, the 'surrounding-characteristics' (i.e. attributes of the agencies) are present in both groups. This makes comparison between experimental and comparison groups possible. Table 1 shows the response during the pre- and post-test.

Table 1 Overviow of the number of respondents during the pre- and post-test

\begin{tabular}{|c|c|c|c|c|c|c|c|c|}
\hline Agency & $\begin{array}{l}\text { Experime } \\
\text { Sample- } \\
\text { size }\end{array}$ & $\begin{array}{l}\text { ental } 9 \\
\text { Pre- } \\
\text { test }\end{array}$ & $\begin{array}{l}\text { Post- } \\
\text { test }\end{array}$ & $\begin{array}{l}\text { Pre- and } \\
\text { post-test }\end{array}$ & $\begin{array}{l}\text { Comparis } \\
\text { Sample- } \\
\text { size }\end{array}$ & $\begin{array}{l}\text { Pon gr } \\
\text { Pre- } \\
\text { test }\end{array}$ & $\begin{array}{l}\text { Post- } \\
\text { test }\end{array}$ & $\begin{array}{l}\text { Pre- and } \\
\text { post-test }\end{array}$ \\
\hline \multicolumn{9}{|c|}{ Differentiated practice } \\
\hline D1 & 64 & 60 & 33 & 31 & 23 & 23 & 18 & 18 \\
\hline D2 & 30 & 24 & 15 & 15 & 31 & 30 & 20 & 19 \\
\hline D3 & 14 & 11 & 11 & 10 & 16 & 16 & 12 & 12 \\
\hline Tolal & 108 & 95 & 59 & 56 & 70 & 69 & 50 & 49 \\
\hline \multicolumn{9}{|c|}{ Spocialization } \\
\hline S1 & 27 & 24 & 16 & 16 & 24 & 9 & 6 & 6 \\
\hline S2 & 19 & 19 & 14 & 14 & 19 & 16 & 13 & 13 \\
\hline \$3 & 10 & 9 & 8 & 7 & 9 & 10 & 5 & 5 \\
\hline S4 & 24 & 16 & 16 & 12 & 16 & 13 & 10 & 10 \\
\hline \$5 & 16 & 16 & 10 & 10 & 16 & 24 & 18 & 18 \\
\hline S6 & 25 & 24 & 21 & 20 & 24 & 18 & 12 & 12 \\
\hline Total & 121 & 108 & 85 & 79 & 108 & 90 & 64 & 64 \\
\hline
\end{tabular}

Concerning differentiated practice 178 community nurses and community nurse auxiliaries participated in the study. They have received before and after the implementation of differentiated practice a questionnaire. $88 \%$ of the experimental group responded on the pre-test and $99 \%$ of the comparison group. Finally $52 \%$ of the experimental group and $70 \%$ of the comparison group participated in both the pre-test and post-test. As regards the agencies D1 and D3 the reason for non-response is mainly unknown. In agency D2 the lower response was caused because of the withdrawal of two teams (one experimental and one comparison team). These teams were faced with changes concerning staffing. To reduce bias as much as possible these teams (respectively 5 and 6 persons) did not participate in the post-test. If 
these teams are not considered the response for the experimental and comparison group is respectively $54 \%$ and $77 \%$.

As regards specialization 229 community nurses and community nurse auxiliaries participated in the study. During the pre-test $89 \%$ of the experimental group and $83 \%$ of the comparison group responded. Finally, $65 \%$ of the experimental group and $59 \%$ of the comparison group responded to both the pre-test and post-test. The reason for non-response is for $80 \%$ unknown. The other $20 \%$ of the non-response is a consequence of another job, illness or pregnancy.

The nurses and nurse auxiliaries who responded only once (= non-response group) were compared to the ones who responded both on the pre- and posttest (= response group). The response-group had significantly higher scores on five variables in the questionnaire. Nurses and nurse auxiliaries in the response group experienced more task significance, were more satisfied with patient-contact, felt themselves more personally accomplished, sought more social support and experienced more support from their supervisor. Thus, the non-respondents seem to be less positive about their work on some aspects than the respondents.

Table 2 describes some biographical characteristics of the respondents in the experimental and comparison groups.

Table 2 Biographical characteristics of the respondents in numbers and means

\begin{tabular}{|c|c|c|c|c|}
\hline & $\begin{array}{l}\text { Differentiated } \\
\text { Experimental } \\
\text { group }(n=56)\end{array}$ & $\begin{array}{l}\text { practice } \\
\text { Comparison } \\
\text { group }(n=49)\end{array}$ & $\begin{array}{l}\text { Specialization } \\
\text { Experimental } \\
\text { group }(n=79)\end{array}$ & $\begin{array}{l}\text { Comparison } \\
\text { group }(n=64)\end{array}$ \\
\hline community nurse & 41 & 33 & 63 & 53 \\
\hline community nurse auxiliary & 15 & 16 & 16 & 11 \\
\hline $\operatorname{man}$ & 7 & 7 & 6 & 0 \\
\hline women & 49 & 42 & 73 & 64 \\
\hline mean age & 37.2 & 35.5 & 37.0 & 37.7 \\
\hline years of employment (mean) & $8.5^{*}$ & $6.0^{*}$ & 9.6 & 8.9 \\
\hline hours employed (mean) & 28.1 & 30.0 & $31.7^{*}$ & $27.9^{*}$ \\
\hline
\end{tabular}

$* p \leq .05$

Table 2 shows that both experimental and comparison groups are comparable on most characteristics. In all groups there is a majority of community nurses, and there are more women than men. The mean age of the respondents varies between 36 and 38 years. As regards differentiated practice a significant difference existed between the experimental and comparison groups on the number of years of employment: the respondents of the 
experimental group are a little longer employed compared to respondents of the comparison group. Concerning specialization the respondents of the experimental group are employed for more hours than the respondents of the comparison group. This last difference is probably a consequence of one of the selection-criteria to be eligible for an area-of-special-expertise.

\subsubsection{Measuring instruments}

To measure the outcomes of differentiated practice and specialization a questionnaire was sent to all participating community nurses and nurse auxiliaries before the start of the intervention and one year later. In this questionnaire attention was paid to job characteristics, individual characteristics, job satisfaction and burnout. Besides, the researcher had several conversations with the 'central-person' of the agency and an evaluation-meeting was organised with the care-givers of the experimental group.

The questionnaire was developed based on the Algera questionnaire (Algera, 1981; Algera et al., 1986) to characterize the nursing roles and measuring job satisfaction. Algera modified and enlarged the Job Diagnostic Survey (Hackman \& Oldham, 1980). Prior to the research conducted by the authors of this study, Boumans (1990) used the Algera questionnaire for nurses in hospitals. Based on these results, a questionnaire was constructed to assess 8 job characteristics (measured by 24 items): time pressure, autonomy, job clarity, skill variety, task identity (the degree to which a job requires completion of a whole and identifiable piece of work, i.e. doing assessments and diagnostics), possibilities for growth at work, feedback and task significance ( $=$ the degree to which the job has a substantial impact on the lives of other people in the immediate organization and in the world at large). Cronbach's $\alpha$ of the subscales ranged from .67 to .79 .

Several individual characteristics were measured: preferences, coping strategies, experienced social support and biographical characteristics. Preferences were measured by 6 subscales (33 items) from the Boumansquestionnaire (1990): preference for career, prestige, autonomy, co-operation, variety and absence of time pressure. The internal consistency of each subscale was high (Cronbach's $a$ ranged from .75 to .93 ). To measure coping strategies the Utrecht Coping List (UCL) (Schreurs et al., 1988) was used. This questionnaire consists of three subscales: an active way of handling problems (7 items, $\sigma=.76$ ), remaining passive (11 items, $\sigma=.71$ ) and seeking social support (6 items, $a=80$ ). Social support experienced at work was measured by the Organizational Stress Questionnaire (VOS-D) (Bergers et al., 1986) including 2 subscales: social support received from the supervisor $(\alpha=.91)$ and social support received from peers $(a=.71)$. Finally, three 
biographical characteristics were used in this study: age, sex and hours of employment.

The Boumans' questionnaire was also used to measure job satisfaction. Eight subscales (measured by 43 items) were included: satisfaction with the quality of care, general work satisfaction, supervisory satisfaction, satisfaction with peers, patient-contact, patient-assignment, clarity and growth at work. The internal consistency of each subscale was acceptable to high (Cronbach's a ranged from .64 to .92$)$. In this chapter the overall score is taken into account $(\alpha=.70)$.

To measure burnout the Dutch version of the Maslach Burnout Inventory (MBI-NL) was used (Schaufeli \& Van Dierendonck, 1994). The MBI-NL consists of three subscales designed to assess the frequency (how often persons have these feelings) of three aspects of burnout: emotional exhaustion, depersonalization and personal accomplishment. A high degree of burnout was reflected in high scores on the emotional exhaustion and depersonalization subscales and in low scores on the personal accomplishment subscale. The inventory is self-administered and the frequency with which the respondents experience feelings related to each subscale is assessed in terms of 22 seven-point Likert type questions $(0=$ never, $6=$ always). Items 12 and 16 were not included because other studies showed that these items do not load on one factor only (Schaufeli \& Van Dierendonck, 1994). Eight items assess emotional exhaustion, depersonalization is measured by five items and seven items assess feelings of personal accomplishment. The internal consistency of each subscale is acceptable to high (Cronbach's $a$ is respectively $.86, .64$ and .77). To get a better idea of the scores on the three dimensions a comparison was made with a 'standard for nurses' presented in the study by Schaufeli \& Van Dierendonck (1994). In that study scores from 2,500 nurses in the Netherlands were analyzed and the mean-scores on the three dimensions were presented as the standard. The authors emphasize that these standards are not yet definitive. On a scale from $0-6$ for emotional exhaustion the standard is 1.9 (scores between 1.1 and 2.5 are average), for depersonalization the standard is 1.4 (scores between 0.6 and 1.8 are average), and for personal accomplishment the standard is 3.9 (scores between 3.4 and 4.3 are average).

To get an overall picture of the outcomes of differentiated practice and specialization attention was also paid to the implementation process in the different agencies. Therefore, in all participating agencies a central-person was appointed. The researcher contacted these persons regularly in 1994 (once per 1-2 months). By means of a semi-structured questionnaire these persons were interviewed to get information about the implementation 
process. Besides, in each agency one evaluation meeting was organized with all the community nurses and nurse auxiliaries of the experimental group. In the period between november 1994 and january 1995 the researcher visited these meetings and took notice of their experiences with the project.

\subsubsection{Analysis}

Mean-scores were calculated and MANOVA for repeated measures was used to analyze whether there were significant differences between the experimental and comparison group on job characteristics, job satisfaction and burnout between the pre-test and post-test. In this analysis individual characteristics were used as covariates.

\subsection{Results}

In this paragraph the results of the questionnaire before and after the implementation of differentiated practice and specialization are presented and discussed per hypothesis.

\subsubsection{Changes in job characteristics related to differentiated practice and specialization}

The effects on job characteristics, job satisfaction and burnout are described in line with the hypotheses in the introduction-section. To what extent these hypotheses are confirmed is shown in table 3 . In this table the results of MANOVA-analysis are presented.

Table 3 Differences in job characteristics between the experimental and comparison groups

\begin{tabular}{|c|c|c|c|c|c|c|c|c|c|c|}
\hline \multirow[b]{2}{*}{ Variables } & \multicolumn{2}{|c|}{$\begin{array}{l}\text { Differentiated } \\
\text { Experimental } \\
\text { group }(n=56)\end{array}$} & \multicolumn{3}{|c|}{$\begin{array}{l}\text { oractice } \\
\text { Comparison } \\
\text { group }(n=49)\end{array}$} & \multicolumn{2}{|c|}{$\begin{array}{l}\text { Specialization } \\
\text { Experimental } \\
\text { group }(n=79)\end{array}$} & \multicolumn{3}{|c|}{$\begin{array}{l}\text { Comparison } \\
\text { group }(n=64)\end{array}$} \\
\hline & Pre & Post & Pre & Post & $p$ & Pre & Post & Pre & Post & p \\
\hline Jab characteristics & (scale & 1-7): & & & & & & & & \\
\hline time pressure & 5.00 & 5.02 & 4.71 & 5.00 & & 5.30 & 5.12 & 4.91 & 5.17 & * \\
\hline autonomy & 4.29 & 4.02 & 4.72 & 4.38 & & 4.32 & 4.25 & 4.45 & 4.05 & \\
\hline task clarity & 6.01 & 5.98 & 5.76 & 5.70 & & 5.93 & 5.91 & 5.95 & 5.93 & \\
\hline skill variety & 5.16 & 4.99 & 5.31 & 5.39 & & 5.19 & 5.14 & 5.08 & 5.02 & \\
\hline task identity & 4.79 & 4.37 & 4.51 & 4.35 & & 4.73 & 4.54 & 4.34 & 4.30 & \\
\hline growth at work & 4.64 & 4.33 & 4.76 & 4.52 & & 3.64 & 4.10 & 3.82 & 3.52 & ** \\
\hline foedback & 4.49 & 4.43 & 4.53 & 4.53 & & 4.34 & 4.42 & 4.26 & 4.01 & - \\
\hline task significance & 5.32 & 5.33 & 5.43 & 5.17 & - & 5.25 & 5.24 & 5.17 & 5.18 & \\
\hline
\end{tabular}

the meaning of the " is as follows: the difference between the pre- and post-test in the experimental group is significantly different from the difference between the pre-and post test in the comparison group; " $p \leq .05 ; " * p .01$ 
Table 3 shows only one significant difference with respect to differentiated practice. The hypothesis that differentiated practice will lead to a higher degree of task clarity was not supported. Differences were however found on task significance with the comparison group showing a significant decrease. The impact of their job on others has diminished. When MANOVA is executed for both types of nurse separately (not presented in table 3 ) some support for the second hypothesis is found: skill variety for community nurse auxiliaries in the experimental group diminished from 5.04 to 4.60 whereas it increased in the comparison group (from 5.09 to 5.33). Separate analysis for community nurses did not yield significant differences.

With respect to specialization table 3 shows three significant differences between the experimental and comparison group with regard to job characteristics. The hypothesis that community nurses and nurse auxiliaries with an area-of-special-expertise will experience more growth at work and more feedback were supported. The hypothesis that they will experience more time pressure was not supported. The comparison group on the other hand, showed significant increases in time pressure. With respect to autonomy and skill variety no significant differences were found.

Separate analysis for both types of nurse did not yield extra information.

\subsubsection{Changes in job satisfaction and burnout related to differentiated practice and specialization}

Table 4 shows to what extent the hypotheses with respect to job satisfaction and burnout are supported.

As regards differentiated practice no significant differences on job satisfaction and burnout were found between the experimental and comparison groups. Separate analysis for both types of nurse showed one difference: community nurses in the experimental group became less satisfied with growth at work (a decrease from 3.49 to 3.38 ) whereas an increase was seen in the comparison group (from 3.41 to 3.59 ). For the community nurse auxiliaries no significantly differences were found. Thus, the hypothesis that differentiated practice will lead to lower levels of job satisfaction and personal accomplishment for community nurse auxiliaries was not supported.

As regards the areas-of-special-expertise community nurses and nurse auxiliaries in the comparison group have become less satisfied on two aspects: with their work in general and with growth at work. This means support for the fifth hypothesis. Besides, the members of the experimental group have become more satisfied with patient-assignment. With respect to burnout no significant differences have been found. No support was found for higher feelings of personal accomplishment (hypothesis 6). Separate 
MANOVA-analysis for both types of nurse added another difference: community nurses in the experimental group became more satisfied with their supervisor (from 3.14 to 3.25 ) whereas in the comparison group supervisory satisfaction decreased (from 3.31 to 3.11 ). Finally, the results show that the expectations of areas-of-special-expertise are diminishing among nurses without such areas.

Table 4 Differences in job satisfaction, burnout, and expectations between the experimental and comparison groups

\begin{tabular}{|c|c|c|c|c|c|c|c|c|c|c|}
\hline \multirow[b]{2}{*}{ Variables } & \multicolumn{2}{|c|}{$\begin{array}{l}\text { Differentiated } \\
\text { Experimental } \\
\text { group }(n=56)\end{array}$} & \multicolumn{3}{|c|}{$\begin{array}{l}\text { practice } \\
\text { Comparison } \\
\text { group }(n=49)\end{array}$} & \multicolumn{2}{|c|}{$\begin{array}{l}\text { Specialization } \\
\text { Experimental } \\
\text { group }(n=79)\end{array}$} & \multicolumn{3}{|c|}{$\begin{array}{l}\text { Comparison } \\
\text { group }(n=64)\end{array}$} \\
\hline & Pre & Post & Pre & Post & $p$ & Pre & Post & Pre & Post & $p$ \\
\hline \multicolumn{11}{|c|}{ Dimensions of job satisfaction (scale 1-5): } \\
\hline total job satisfaction & 3.63 & 3.52 & 3.63 & 3.50 & & 3.58 & 3.58 & 3.59 & 3.46 & * \\
\hline with quality of care & 3.44 & 3.41 & 3.73 & 3.63 & & 3.56 & 3.58 & 3.55 & 3.50 & \\
\hline general work satisfaction & 3.76 & 3.61 & 3.93 & 3.77 & & 3.69 & 3.71 & 3.72 & 3.44 & $\star \star$ \\
\hline supervisory satisfaction & 3.57 & 3.37 & 3.33 & 3.12 & & 3.25 & 3.31 & 3.35 & 3.20 & \\
\hline with peers & 3.90 & 3.75 & 3.74 & 3.70 & & 3.90 & 3.75 & 3.88 & 3.80 & \\
\hline with patient-contact & 3.78 & 3.64 & 3.82 & 3.61 & & 3.91 & 3.72 & 3.90 & 3.74 & \\
\hline with patient-assignment & 3.42 & 3.30 & 3.18 & 3.05 & & 2.83 & 3.18 & 3.24 & 3.27 & - \\
\hline with clarity & 3.49 & 3.51 & 3.43 & 3.46 & & 3.49 & 3.48 & 3.46 & 3.46 & \\
\hline with growth at work & 3.47 & 3.38 & 3.50 & 3.50 & & 3.36 & 3.41 & 3.34 & 3.15 & * \\
\hline \multicolumn{11}{|c|}{ Bumout-dimensions (scale a-6): } \\
\hline emolional exhaustion & 2.00 & 2.18 & 2.01 & 2.09 & & 2.03 & 2.12 & 2.20 & 2.34 & \\
\hline depersonalisation & 1.15 & 1.34 & 0.99 & 1.17 & & 1.03 & 1.26 & 1.11 & 1.23 & \\
\hline personal accomplishment & 4.09 & 4.01 & 4.15 & 4.10 & & 4.15 & 4.06 & 4.06 & 4.01 & \\
\hline \multicolumn{11}{|l|}{ Expoctations (scale 1-5): } \\
\hline about diff.practice & 3.47 & 3.47 & 3.71 & 3.59 & & n.a. & n.a. & n.a. & n.a. & \\
\hline about specialization & n.a. & n.a. & n.a. & n.a & & 3.37 & 3.32 & 3.27 & 3.02 & * \\
\hline
\end{tabular}

the meaning of the " is as follows: the difference between the pre- and post-test in the experimental group is significantly different from the difference between the pre-and post test in the comparison group: " $p \leq .05 ; " p \leq .01$

Controlling the effects of individual characteristics

In line with the research model presented before (figure 1) individual characteristics were also taken into account (as covariates) to measure the effects on job satisfaction and burnout.

With respect to the 'differentiated practice group' no differences were found on individual characteristics between the experimental and comparison group with exception of 'years of employment' (see table 2). However, when this variable was used as covariate no changes in the results presented in table 4 were found. 
In the 'specialization group' a significant difference in favour of the experimental group was found on experienced supervisory support. Chapter 4 showed that supervisory support affects job satisfaction positively and burnout negatively. Therefore, as regards the 'specialization group' the same analysis was done with supervisory support as covariate together with the variable 'hours of employment' (see table 2). When these two variables were used as covariates in the analysis the difference on total satisfaction and the difference on satisfaction with growth at work disappeared while the other differences presented in table 4 remained.

\section{Additional information from the evaluation-meetings}

Beside the results in the above presented tables the evaluation-meetings gave also some information about the effects of differentiated practice and specialization. As regards differentiated practice it became obvious that not all community nurses and community nurse auxiliaries were satisfied with the new job-profiles. At first, this dissatisfaction concentrated on the fact that community nurse auxiliaries felt controlled by community nurses. In addition, respondents said that it is easy to make a differentiation on paper but that this is not congruent with practice (e.g. because staffing is not appropriate). As regards the instrument for patient assignment mariy of the nurses and nurse auxiliaries asked why they had to fill in this form because they already had to fill in so many forms. Subsequently, in the beginning it became obvious that it was not always easy to answer all the questions. However, after the nurses became used to the instrument they filled it in with more easiness and became aware of the usefulness of the instrument. It was considered as positive that the instrument gave insight in the reasons for assignment. Furthermore, because nurses had sometimes different meanings for assignment interesting discussions followed. This was not applied to all nurses and nurse auxiliaries. Some community nurses used the instrument because they had to, and not as resource for patient assignment. One of the main reasons is the workload that makes it difficult to find time to fill in the instrument. Others considered the instrument as threatening. They felt anxious that the use of the instrument would have negative consequences for staffing when a lot of nursing situations would be judged as not-complex (that would mean that more community nurse auxiliaries are needed at the cost of community nurses).

As regards specialization nurses and nurse auxiliaries were very positive about the further training they got. They became aware of the knowledge they missed about their area. These nurses and nurse auxiliaries showed to be very positive and motivated to develop their area-of-special-expertise. The meetings with peers with regard to their area were judged as useful because of the exchange of expertise and knowledge. Finally, the nurses and nurse 
auxiliaries found it difficult to reserve time for their area-of-special-expertise. They are not yet used to schedule also time for study and not only for 'doing' activities.

\subsubsection{Additional results: overall changes in job characteristics, job satisfaction and burnout}

Analysis of pre- and post-test data for the total group of differentiated practice (experimental- and comparison group together) and the total group of specialization, revealed a number of significant changes. The results are presented in table 5.

Table 5

Differences between the pre-test and post-test for the total groups

\begin{tabular}{|c|c|c|c|c|}
\hline \multirow[b]{2}{*}{ Variables } & \multicolumn{2}{|c|}{$\begin{array}{l}\text { Differentiated practice } \\
\text { Total group }(n=105)\end{array}$} & \multicolumn{2}{|c|}{$\begin{array}{l}\text { Specialization } \\
\text { Total group }(n=143)\end{array}$} \\
\hline & Pre-test & Post-test & Pre-test & Post-test \\
\hline \multicolumn{5}{|l|}{ Job characteristics (scale 1-7): } \\
\hline time pressure & 4.86 & 5.01 & 5.13 & 5.14 \\
\hline autonomy & 4.49 & 4.19* & 4.38 & 4.16 \\
\hline task clarity & 5.89 & 5.85 & 5.94 & 5.92 \\
\hline skill variety & 5.23 & 5.18 & 5.14 & 5.09 \\
\hline task identity & 4.64 & $4.36^{\star \star *}$ & 4.56 & 4.43 \\
\hline growth at work & 4.70 & 4.42 & 3.72 & 3.84 \\
\hline feedback & 4.51 & 4.48 & 4.30 & 4.24 \\
\hline task significance & 5.37 & 5.26 & 5.21 & 5.21 \\
\hline \multicolumn{5}{|l|}{ Dimensions of } \\
\hline lotal job satisfaction & 3.63 & $3.51^{\text {**m+ }}$ & 3.58 & $3.53^{*}$ \\
\hline with quality of care & 3.58 & 3.51 & 3.56 & 3.54 \\
\hline general work satisfaction & 3.84 & $3.68^{*}$ & 3.70 & $3.59^{*}$ \\
\hline supervisory satisfaction & 3.46 & $3.25^{* *}$ & 3.29 & 3.26 \\
\hline with peers & 3.83 & 3.73 & 3.89 & $3.77^{* *}$ \\
\hline with patient-contact & 3.80 & $3.63^{* *+4}$ & 3.91 & $3.73^{\text {t*a** }}$ \\
\hline with patient-assignment & 3.31 & 3.18 & 3.01 & $3.22^{\text {** }}$ \\
\hline with clarity & 3.46 & 3.49 & 3.48 & 3.47 \\
\hline with growth at work & 3.48 & 3.43 & 3.35 & 3.29 \\
\hline \multicolumn{5}{|l|}{ Bumout-dimensions (scale 0-6): } \\
\hline emotional exhaustion & 2.00 & 2.14 & 2.11 & $2.22^{*}$ \\
\hline depersonalisation & 1.08 & $1.26^{* *}$ & 1.07 & $1.25^{\star *}$ \\
\hline personal accomplishment & 4.12 & 4.05 & 4.11 & $4.04^{*}$ \\
\hline \multicolumn{5}{|l|}{ Expoctations (scale 1-5) } \\
\hline about differentiated practice & 3.58 & 3.53 & n.a. & n.a. \\
\hline about specialization & n.a. & n.a. & 3.33 & 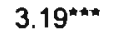 \\
\hline
\end{tabular}

$* p \leq .05 ; * p \leq .01 ; * 0 \leq 001$

First of all can be concluded that during the post-test in both groups the job characteristics are present to a reasonable extent (mean-scores vary from 
3.84 to 5.92 on a scale from 1-7), the nurses and nurse auxiliaries are reasonably satisfied (scores between 3.18 to 3.77 on a scale from 1-5), and the burnout scores can be considered as average compared to the standards presented by Schaufeli \& Van Dierendonck (1994).

As regards the job characteristics in the 'differentiated practice group' two significant differences were found between the pre- and post-test: both the level of autonomy and the extent of doing assessments and diagnostics (i.e. task identity) has decreased.

With respect to job satisfaction in both groups a negative tendency is seen. Community nurses and community nurse auxiliaries have become less satisfied with several aspects. Notable is the decrease in satisfaction with patient-contact. Further analysis in the 'differentiation group' also showed that the decrease of satisfaction with growth at work was greater for community nurse auxiliaries (from 3.56 to 3.33) than for nurses (from 3.45 to 3.47). With respect to the 'specialization group' only one difference was found between the types of nurse: community nurses became less satisfied with the contacts with peers (from 3.90 to 3.73 ) whereas community nurse auxiliaries became little more satisfied with these contacts (from 3.87 to 3.94 ).

Regarding burnout also a negative development is seen between pre-test and post-test. Within the 'differentiated practice group' persons feel themselves more depersonalized. Further analysis also showed that feelings of personal accomplishment have decreased more for community nurse auxiliaries (from 4.18 to 3.99 ) than for community nurses (from 4.09 to 4.08 ). The members of the 'specialization group' feel themselves more emotionally exhausted, more depersonalized, and personally less accomplished. Differences between the two types of nurse were not found.

Again the individual characteristics were taken into account. With respect to the total 'differentiated practice group' no significant differences were seen on the individual characteristics when the pre- and post-test were compared. As regards the total 'specialization group' the presence of four individual characteristics decreased between the pre- and post-test: preference for skillvariety, preference for co-operation, preference for absence of time pressure, and active coping approach. Therefore the same analysis was done with these individual characteristics as covariates. The results of this analysis showed that most significant differences presented in table 5 remained, except for the difference on the total job satisfaction and the difference on personal accomplishment. 


\subsection{Discussion}

In this study the outcomes of two types of work-redesign in community nursing were studied in terms of job characteristics, job satisfaction and burnout. Some of the hypotheses formulated at the beginning of the study were supported by the results and some were not.

As regards differentiated practice the use of job profiles and the instrument for patient assignment has not led to more clarity about the difference between nursing roles. The reason for this is probably that task clarity was to a large extent present as exemplified by the high scores on this variable. In other words, it was almost impossible to reach a higher level of task-clarity.

In addition, the hypothesis that differentiated practice has negative effects for community nurse auxiliaries (second level nurse) was confirmed. For this type of nurse, skill variety diminishes when differentiated practice is implemented. It was not possible to conclude from the data if this leads to lower levels of satisfaction or higher levels of burnout for community nurse auxiliaries compared to community nurses. On the other hand, the results did show that community nurses working with differentiated practice became less satisfied with growth at work compared to the nurses who did not use job profiles and the instrument for patient assignment. This result may be due to the fact that nurses working with differentiated practice, have perceived this change as restrictive to their job performance and consequently their autonomy. This is illustrated by comments made during the evaluation meetings. Some nurses said that they have the feeling to justify everything they perform, and that their autonomy was attacked.

Compared to research in the United States of America (Hersterly et al, 1986; Koerner et al., 1989; American Organization of Nurse Executives, 1990; Malloch et al., 1990; Martin \& McGuire, 1990; Jung et al., 1994; Corley et al., 1994; Hutchens, 1994) the effects of differentiated practice in this study are less extensive. The reason for this is probably the difference in content. Implementation of differentiated practice in the United States has a greater impact on nursing roles. After implementation of differentiated practice in the United States it is possible that an associate degree nurse performs the role of first level nurse and a nurse with a baccalaureate degree the role of second level nurse. In Dutch community nursing however, nurses with a baccalaureate degree always perform as first level nurses and nurses with associated degree as second level nurses. Therefore, differentiated practice in this study mainly focused on the use of an instrument for patientassignment.

As regards areas-of-special-expertise three significant differences were found with respect to job characteristics. This type of work-redesign leads to less 
time pressure, more growth at work and more feedback. The outcomes did not differ between the two types of nurse. Based on the study of Van Bragt (1993) it was hypothesized that time pressure increases when nurses get an area-of-special-expertise. The reason that the hypothesis was not supported is plausibly due to the fact that these nurses were given time to use for the areas (varying from four hours a week to four hours a month). However, although time was available most nurses and nurse auxiliaries found it difficult to reserve time for their area-of-special-expertise, because of the fact that they are not yet used to schedule also time for study and not only for 'doing' activities.

As regards the positive effects of specialization on job satisfaction supporting data were found (on general work satisfaction, with patient-assignment and growth at work). This is probably a consequence of the changed job characteristics. For example, the studies by Blegen (1993) and Parahoo \& Barr (1994) showed that feedback (i.e. communication with peers/colleagues and multi-disciplinary team work) contribute to job satisfaction. However, the results did not show a clear increase of satisfaction but rather a prevention of becoming dissatisfied. The satisfaction-levels were maintained over a period of one year for the specialized nurses contrary to the results in the comparison group who showed decreased levels of satisfaction. This may be due to the fact that it took in most agencies more preparation than expected, to realize the areas-of-special-expertise. Therefore an increase on satisfaction could not be expected. In addition, the results in this study showed that the total group of community nurses and community nurse auxiliaries became less satisfied and showed more feelings of burnout in a period of one year. It seems that external changes in community nursing (e.g. more attention for productivity, flexibility, efficiency) have had an impact on the work of nurses and nurse auxiliaries.

As regards burnout no significant effects were found for both differentiated practice and areas-of-special-expertise. This result is congruent with the results in chapter 4 . Those results showed that changes in job characteristics may have more impact on job satisfaction whereas changes in individual characteristics may have more influence on levels of burnout. In line with this, the investigated types of work redesign (i.e. changing job characteristics by means of differentiated practice and specialization) did not change feelings of burnout. On the other hand, studies showed that some job characteristics affect burnout, for example: role conflict, role ambiguity (Siefert et al., 1991), amount of challenge (De Jonge et al., 1994; De Jonge, 1995), workload and autonomy (De Jonge et al., 1994; De Jonge, 1995; chapter 4). However, these job characteristics did not change as a consequence of differentiated 
practice and specialization. In line with this, no differences in burnout levels were found.

The increase of feelings of burnout for the total group may be due to the higher tension that is put on community nursing by stressing the importance of productivity, flexibility and efficiency. This is congruent with the study by McGrath et al., (1989). That study showed that moderate or high stress levels in nursing are caused by having insufficient time to perform duties to the nurse's satisfaction and to the rationing of scarce services or resources. 


\subsection{References}

Algera, JA. (1981). Kenmerken van werk (Job characteristics). PhD thesis. Lisse: Swets \& Zertlinger.

Algera J.A., Flier H. van der \& Kamp L.J.Th. van der (1986). Causal modeling of quality of work. In: The Psychology of Work and Organization (Debus G. \& Schroiff H.W.) (pp. 175 - 182). Amsterdam: Elsevier Science Publishers.

American Organization of Nurse Executives (1990). Current issues and perspectives on differentiated practice. Chicago: American Hospital Association.

Bergers, G.P.A., Marcelissen, F.G.H. \& Wolf Ch.J. de (1986). VOS-D Vragenlijst Organisatiestress- $D$, Handleiding (VOS-D Questionnaire Organization-stress-D, Manual). Stressgroep publikatie 36 .

Blegen M.A. (1993). Nurses' job satisfaction: a meta-analysis of related variables. Nursing Research 42(1), 36-41.

Boston C.M. (1990). Introduction. In: Current issues and perspectives on differentiated practice (pp. 1-3). Chicago: American Organization of Nurse Executives, 1-3.

Boumans N.P.G. (1990). Het werk van verplogkundigen in algemene ziekenhuizen: een onderzoek naar werkaspecten en hun invloed op verpleegkundigen (The work of nurses in hospitals: a study about job characteristics and their effects on nurses). Maastricht: Rijksuniversiteit Limburg.

Bragt M.J.A.B. van (1993). Het gedifferentieerd en allround werken binnen de wijkverpleging. Een onderzoek bij Kruiswerk West-Brabant en Stichting Interkruis Noord-Kennemerland (Specialization and non-specialization in community nursing. $\dot{A}$ study camied out at Kruiswerk West-Brabant and Stichting Interkruis Noord-Kennemertand). Maastricht: Rijksuniversiteit Limburg.

Corley M.C., Farley B., Geddes N., Goodloe L. \& Green P. (1994). The clinical ladder: impact on nurse satisfaction and turnover. The Joumal of Nursing Administration 24(2), 42-48.

Griffiths J., Luker K. (1994). Community nurse attitudes to the clinical nurse specialist. Nursing Times 90(17), 39-42.

Haaren E. van (1994). De expert: Carrière maken met de handen aan het bed. (The expert: A career at the bedside). MGZ 22(4), 26-28.

Habes V. (1995). Op zoek naar de gulden middenweg (Seeking the golden mean.) Tijdschrih voor Ziekenverpleging (19), 574.

Hackman J.R. \& Oldham G.R. (1980). Work redesign. Massachusetts: Addison-Wesley Publishing Company, Inc..

Haste F.H. \& MacDonald L.D. (1992). The role of the specialist in community nursing: perceptions of specialist and district nurses. International Joumal of Nursing Studies 29(1), $37-47$.

Hesterty S. \& Sebilia A.J. (1986). Recognizing clinical excellence. The Joumal of Nursing Administration 16(12), 34-38.

Hickey M., Billings D.M., Disch J., Eagleton B., Carty Farrell M., Turzan L. \& Vitello J.M. (1991). Competence statements for differentiated nursing practice in critical care. Focus on critical care 18(4), 286-293.

Hutchens G.C. (1994). Differentiated Interdisciplinary Practice. The Joumal of Nursing Administration 24(6), 52-58.

Jansen P.G.M. \& Kerkstra A. (1993). Functiodifferentiatio binnen de thuiszorg. De functies van wijkerplogkundige, wijkverpleogster en gezinsverzorgende nader omschreven (Differentiated practice and spocialization in home care. The roles of the community nurse, community nurse auxiliary and home help in detail). Utrecht: NIVEL. 
Jansen P.G.M. \& Kerkstra A. (1995). Effecten van functiedifferentiatie binnen de thuiszorg (Outcomes of differentiated practice and specialization in community nursing) (pp. 49-62). Utrecht: NIVEL.

Jonge J. de, Janssen P. \& Landeweerd A. (1994). Effecten van werkdruk, autonomie en sociale ondersteuning op de werkbeleving van verplegenden en verzorgenden (Effects of workload, autonomy and social support on work-experience of nurses and nurse auxiliaries). Verpleogkunde (1), 17-26.

Jonge de J. (1995). Job Autonomy, well-being and Health: a study among Dutch health care workers. PhD-thesis. Maastricht: Datawyse B.V. I Universitaire Pers.

Jung F.D., Pearcey L.G. \& Philips J.L. (1994). Evaluation of a program to improve nursing assistant use. The Joumal of Nursing Administration 24(3), 42-47.

Ketelaars C. (1996). Aftercare and specialised community nursing. Implications for patients with chronic obstructive pulmonary disease. PhD-thesis. Den Haag: Koninklijke Bibliotheek.

Kiers J. (1993). Samenwerking wijkverpleegkundige en consulente kán ideaal zịn (Cooperation between community nurse and consultant can be ideal). MGZ 21(7), 22-25.

Koerner J.E. (1990). The relevance of differentiated practice in today's environment. In: Current issues and perspectives on differentiated practice, Chicago, American Organization of Nurse Executives. (pp. 35-51).

Koerner J.E., Birch Bunkers L., Nelson B. \& Santema K. (1989). Implementing differentiated practice: the Sioux Valley hospital experience. The Joumal of Nursing Administration 19(2), 13-20.

Malloch K.M., Milton D.A. \& Jobes M.O. (1990). A model for differentiated nursing practice. The Joumal of Nursing Administration 20(2), 20-26.

Martin S.D. \& McGuire M. (1990). A clinical ladder for the community health-care setting. Joumal of Community health nursing 7(4), 189-197.

McClure M.L. (1991). Differentiated nursing practice: concepts and consideration. Nursing Outhok 39(3), 106-110.

McGrath A., Reid N. \& Boore J. (1989). Occupational stress in nursing. Intermational Joumal of Nursing Sludies 26(4), 343-358.

McKenna H.P. (1995). Nursing skill mix substitutions and quality of care: an exploration of assumptions from the research literature. Joumal of Advanced Nursing 21, 452-459.

Moons M., Kerkstra A. \& Biewenga T. (1994). Specialized home care for patients with AIDS: an experiment in Rotterdam, The Netherlands. Joumal of Advanced Nursing 19, 1132-1140.

Murphy M. \& DeBack V. (1990). Myths and realities. In: Current issues and perspectives on differentiated proctice (pp. 5-16). Chicago: American Organization of Nurse Executives.

National Council for Health Care (1988). Verploegkundig beroepsprofiel (Nursing profile). Zoetermeer: National Council for Health Care.

Parahoo K. \& Barr O. (1994). Job satisfaction of community nurses working with people with a mental handicap. Joumal of Advanced Nursing 20, 1046-1055.

Primm P.L. (1986). Entry into practice: competency statements for BSNs and ADNs. Nursing Outlook 34(3), 135-137.

Primm P.L. (1987). Differentiated Practice for ADN- and BSN-Prepared Nurses. Joumal of Professional Nursing 4, 218-225.

Primm P.L. (1988). Implementation of differentiated practice through differentiated case management. Michigan Nurse (9), 33.

Primm P.L. (1990). Approaches and strategies. In: Cument issues and perspectives on differentiated practice (pp. 17-34). Chicago: American Organization of Nurse Executives.

Schaufeli W. \& Dierendonck D. van (1994). Burnout, een begrip gemeten. De Nederlandse versie van de Maslach Bumout Inventory (MBI-NL) (Burnout, measuring a concept. The Dutch version of the Maslach Burnout Inventory (MBI-NL)). Gedrag \& Gezondheid 22(4), 153-171.

Schreurs P.J.G., Willige G. van de, Tellegen B. \& Brosschot J.F. (1988). De Utrechtse Coping Lijst: UCL-handleiding (The Utrocht Coping List: UCL-manual). Lisse: Zwets \& Zeitlinger. 


\section{Chapter 6}

Siefert K., Jayaratne S. \& Chess W.A. (1991). Job satisfaction, burnout, and turnover in health care social workers. Health and social work 16(3), 193-202.

Wiegers T.A. (1992). Evaluatie van modellen voor aansluiting tussen intramurale specialistische en extramurale verpleogkundige cara-zorg voor kinderen (Assessment of models for the interface between intramural specialist CNSLO care and extramural CNSLD nursing care for children). Utrecht: NIVEL. 


\section{OUTCOMES OF DIFFERENTIATED PRACTICE AND SPECIALIZATION IN COMMUNITY NURSING ON QUALITY OF CARE: \\ viewed from the perspective of the patient ${ }^{1}$}

\subsection{Summary}

In community nursing, work has been redesigned in terms of differentiated practice (=skill $\mathrm{mix}$ ) and specialization (i.e. areas-of-special-expertise). The aim of the redesign is the efficient use of staff, and maintenance or improvement of the quality of care. In this chapter the effects of differentiated practice and specialization in respect of quality of care are studied. The perspective of the patient has been taken as the starting point. Accordingly, quality of care has been defined as the discrepancy between patients' expectations and perceptions of several aspects of care. The effects of the work redesign were determined on the basis of a comparison between an experimental $(n=103)$ and a comparison group $(n=108)$. Data analysis revealed very few differences. Possible explanations for this are the premature status of the projects and the fact that patients are usually (highly) satisfied. The margin in which differences between the experimental and comparison groups might occur is therefore very small. However, this method can provide a detailed picture of the subjective standards patients use to judge the quality of care.

\subsection{Introduction}

Productivity, flexibility, efficacy and quality are terms with which nursing is increasingly being confronted. As a result of this, within the agencies for community nursing in the Netherlands, attention is paid to differentiated practice and specialization among other things. On the one hand, the issue relates to the division of labour (demarcation and harmonization) between community nurses, community nurse auxiliaries and home helps. This latter is referred to as differentiated practice. As regards community nursing, a major differentiating role is played by patient assignment on the basis of the degree of nursing complexity. On the other hand attention is paid to the promotion of expertise and its maintenance in nursing, in other words, specialization. In the development of what are called areas-of-special-expertise, the community

This chapter is an adapted version of the article Jansen P.G.M., Kerkstra A., Abrahamse A., Zee J. van der, Huijer Abu-Saad H. Accepted by Verpleogkunde. 
nurses and their auxiliaries have the opportunity of acquiring specific expertise in addition to their normal work for particular categories of patients. This allows colleagues to consult carers on their area-of-special-expertise (chapter 2 and 3 ). The use of differentiated practice and areas-of-specialexpertise ensures that the patient is given the right type of care by the right sort of person. The judgement of the patient is extremely important in assessing the extent to which this objective is reached. In other words, we are asking about the quality of care from the perspective of the patient. Consequently, to provide an assessment of this, research was carried out on the basis of the following question: What is the effect of differentiated practice and specialization within community nursing on the quality of care viewed from the patients' perspective?

In this chapter we will first give a description of the concept of quality of care and show the relationship between it and differentiated practice and specialization. We will then describe the measuring instrument which is used to determine quality from the perspective of the patient. Finally, results of the research on the effects of differentiated practice and specialization on the quality of care will be presented.

\subsubsection{Quality of care from the patients' perspective: theoretical back- ground}

The Health Research Council defines quality as follows: 'quality is the degree to which the totality of the qualities of a product, process and service meets the requirements ensuing from its objective (Health Research Council, 1990). According to the Council, the objective of use cannot be stated simply, but is determined by the parties in different ways.

Patients and carers may, therefore, have different judgments about the quality of the care provided. Patients may, for example, be dissatisfied whereas care has been provided in terms of professional standards (Bleys, 1986). In this chapter, the assessment of the patient is pivotal. The very fact that in health care there is an increasing reference to clients instead of patients reveals that the person to be provided with care must be seen as a client with particular wishes and expectations. On the basis of the expectations that a patient has, he/she will give an assessment of the care that he/she has received. However, to ask only the patient about whether he/she is satisfied or dissatisfied about the care received in order to assess the quality of care would not give a complete answer. The satisfaction of patients is not seen as an integral measure of the quality of the care supplied, but is, on the other hand, suitable as a possible indicator of the quality of care (Harteloh and Casparie, 1991; Van de Aast et al. 1994). 
A recent review of the literature on the instruments available for measuring of patient satisfaction and the quality of care shows that particular attention has been paid to the satisfaction of the patients and that in many cases no theoretical framework has been adopted (Van Campen et al., 1992, 1995). Where use has been made of a theoretical framework (Linder-Pelz, 1982; Pascoe, 1983; Strasser ot al., 1993), the discrepancy between expectations and perception appear to play a major role. A distinction is made between attitude and expectation based on the theory of Fishbein \& Ajzen by LinderPelz (1982). An attitude is described as a favorable or unfavorable feeling about something. This attitude (in this case patient satisfaction) is determined by the interaction between expectations on the one side, and affective judgement on the other. Pascoe (1983) criticized this emphasis on affective response. For, in addition to affective response, cognitive assessment also plays a role. The reaction and evaluation are based on a subjective standard. This is an ideal image or an expectation based on previous experience. Experience with health is assessed on the basis of this standard. The model has been further developed by Strasser ot al. (1983). In these theories on patient satisfaction, the emphasis is on an attitude or general feeling on the part of patient in relation to various aspects of care (Van Campen et al., 1995). Although in many theories a distinction is made between expectation and perception, both aspects are generally not measured separately. It is often regarded as satisfactory merely to record the (dis)satisfaction of the patient, whereas it is not clear what this is based upon (Sixma, in press). Consequently, the principles on which the patients' subjective standard of judgement is based remain unclear.

In consumer research, the discrepancy between expectation and perception has been further developed in a measuring instrument. An example of this is SERVQUAL, which is based on the Service Quality model of Parasuraman et al. (1985). In contradistinction to the research on patient satisfaction, the emphasis within consumer research is on quality. The opinion of the consumer is seen as part of the cycle of quality improvement and not as an autonomous research topic (Ovretveit, 1992). This approach fits in with the developments that are currently in the foreground in health care, where the patient is seen as a client with particular wishes and expectations. For this reason, in the current research the assessment of the patient is viewed as the discrepancy between the observation of the care received and expectations of care. The quality of care can be regarded as good when the expectation meets or is lower than the care provided. As the expectation of care is higher than the observation, then it is concluded that the quality leaves something to be desired. 
As the quality of care that the patient receives has various aspects, in determining its quality a relationship is sought with existing lists of aspects of quality (Health Research Council, 1990; Dutch Organization for Scientific Research (1992); Post et al., 1993). On the basis of a critical analysis, Post et al., 1993 have shortened the Dutch Organization for Scientific Research (1992) list. The following subdivision is used as a ranking principle: structure (care setting), technology (medical and nursing technologies), interpersonal style (relation with the patient in the case of medical/nursing treatment) and the results (final change in patient condition). Finally, the aspects of the Dutch Organization for Scientific Research (1992) are placed within this ranking, allowing the overlapping definitions and aspects to be conflated. This has resulted in the survey below. For a definition of the various aspects, the reader is referred to the appendix.

Table 1 Quality aspects of the provision of care to be judged by the patients

\begin{tabular}{|c|c|c|c|}
\hline $\begin{array}{l}\text { Structure } \\
\text { 1. availability } \\
\text { 2. accessibility } \\
\text { 3. accomodation }\end{array}$ & $\begin{array}{l}\text { Technical aspect } \\
\text { 4. assessment } \\
\text { 5. expertise } \\
\text { 6. continuity } \\
\text { 7. nutrition } \\
\text { 8. support to } \\
\text { informal carers }\end{array}$ & $\begin{array}{l}\text { Interpersonal aspect } \\
9 . \quad \text { humaneness } \\
\text { 10. provision of } \\
\text { information } \\
\text { 11. guidance } \\
\text { 12. privacy }\end{array}$ & $\begin{array}{l}\text { Result } \\
\text { 13. efficacy } \\
\text { 14. total load } \\
\text { 15. suitability }\end{array}$ \\
\hline
\end{tabular}

Source: Post et al., 1993

\subsubsection{Differentiated practice and specialization in relation to quality of care}

A choice has been made, from the aspects in table 1 , to enable the measurement of differentiated practice and specialization in terms of quality of care. Differentiated practice means, on the one hand, the division of labour and demarcation between the community nurse and the nurse auxiliary in community nursing. The Dutch Nursing Profile is used as the point of departure for this (National Council for Health Care, 1988). On the other hand, differentiated practice refers to the division of labour and demarcation between community nursing and home help. The difference between the community nurse auxiliary and the home help, is pivotal in this ${ }^{2}$.

Differentiated practice is not expected io lead directly to a change in quality as perceived by patients, but to the maintenance of quality. An aspect that

2 In the Netherlands there are five types of carer employed by home help services. Between these carers the emphasis on domestic activities and caring activities differs. Differentiated practice among these carers was not part of this research. In this study we are concerned with home help service in client situations where there is cooperation with community nursing. This concerns carers who have a 3-year secondary school training program. 
might be influenced is continuity. It is expected that the careful procedure by which the patient is allocated to a carer, will lead to a better transfer in the absence, or replacement of a carer. On the other hand, it is possible that effects may occur at the organizational level because of the more efficient use of staff. An attempt is always made to place the right community nurse, nurse auxiliary or home help in the right place in terms of the complexity of the nursing situation and making a clear distinction between community nursing and home help service. This sort of efficiency is, however, of a different order, when viewed from the perspective of the patient: suitability is the relationship between the efficacy of care and the total load of the patient/consumer as a result of that care (see the appendix).

In respect of specialization in community nursing, an attempt has been made to adapt the package of services to the quality demanded by the care system. In the context of this research, the areas-of-special-expertise have been circumscribed by the community nurses and nurses auxiliaries. Subdivision into areas-of-special-expertise was mostly in accord with the patient categories of the participating agencies for community nursing. Examples of areas-of-special-expertise are chronic non specific lung diseases (CNSLD), oncology, diabetes mellitus, neurology, psychogeriatrics, incontinence and wound/colostomy care. The carers have carried out a range of tasks such as keeping their own expertise up to date in respect of the areas-of-specialexpertise, providing consultations, giving guidance, training colleagues and setting up and maintaining a documentation system relating to the areas-ofspecial-expertise.

In contradistinction to differentiated practice, it is expected that the quality of the care will be improved by specialization on several aspects. As community nurses and community nurse auxiliaries will receive training in their areas-ofspecial-expertise, they are expected to better be able to keep their skills up to date and/or to develop them. It is expected that this expertise will be demonstrated in the provision of care in various ways: in the provision of information, humaneness (e.g. concern, friendliness, patient sincerity, respect) guidance, support to informal carers, efficacy, total load and suitability.

In summary, we expect that where differentiated practice and specialization have an effect on the quality of care that it will be detected by the patient in the three clusters from table 1: the working methods, interpersonal communication and the results. On the basis of the definitions in the appendix, it would appear that the cluster 'structure' is not relevant because, in it, the accent is on the physical and geographical environment within which the differentiated practice and specialization takes place. In view of the fact that differentiated practice and specialization relate to changes in content as regards the role of carers, change in structural environment (i.e. availability, 
access and accommodation) is not relevant. In addition to this cluster, three aspects of quality that Post et al. (1993) describe within the remaining three clusters will also not be viewed as important in the context of differentiated practice and specialization. These are nutrition, privacy and assessment. The aspects of nutrition and privacy are not taken into consideration because it is not logical to expect that their quality has anything to do with differentiated practice and specialization. The aspect assessment is disregarded because this focuses on the assessment at the beginning of the period of care. As so called 'assessment nurses' establish the assessment within a number of the participating agencies and the patient is then cared for by other community nurses or community nurse auxiliaries (with or without the particular specialization), it is not possible to determine whether working with areas-ofspecial-expertise has any effect on positing the assessment. In addition to this, most patients have already been looked after by the agencies for community nursing for a long time and as result, many of them would be unable to remember much about the original assessment (Verheij ot al., 1993). We do take account of the fact in this study that there is ongoing attention to the (re)assessment during care. This is interwoven with aspects such as expertise and the provision of information.

\subsection{Method}

In this section, we give a brief description of the interventions that have taken place; of the patients who participated in the investigation; the measuring instrument that was developed; and the statistical analyses that were carried out.

\subsubsection{Intervention}

In total nine agencies for community nursing throughout the Netherlands participated in the investigation. These were agencies which were to start operation at the beginning of 1994 with one of the two forms of work(re)design, i.e. differentiated practice or specialization (i.e. areas-of-specialexpertise). This enabled it to distinguish between an experimental group and a comparison group within the agency. Of the nine participating agencies, three made use of differentiated practice and six focused on specialization. Among the agencies which focused on differentiated practice, there was a strict division between the comparison and the experimental groups, because they were formed on the basis of existing teams. The allocation of the teams to the comparison and experimental groups took place on the basis of pragmatic considerations, paying attention to the comparability of the groups. Another approach was adopted for specialization. Since working with areasof-special-expertise makes particular demands on the carer (in terms of 
experience, full or part-time job, motivation), carers with areas-of-specialexpertise were selected on the basis of written applications and interviews. Those who were not assigned an area-of-special-expertise, formed the comparison group.

In the context of differentiated practice, a number of teams per agency (i.e. the experimental group) made use of an assignment instrument. This allowed the complexity of nursing care to be determined on the basis of various criteria and also established what sort of carer (community nurse or community nurse auxiliary) was most appropriate to look after the patient. For a more detailed description of the reliability and validity of the instrument, the reader is referred to chapter five of this dissertation. Of these three agencies, one worked with integrated teams. In this particular agency, a distinction was also made between community nursing and home help service with help of the instrument. In the period from June 1994 through January 1995, these instruments were used on each occasion in establishing the assessment of new patients. The form was added to the nursing care plan and then an attempt was made with the assistance of the instrument to come to an assessment of complexity and the assignment of the right type of carer. It was not always possible to meet these requirements, because there were sometimes shortages in staff (i.e. too many community nurses as against community nurse auxiliaries) or because a particular nurse auxiliary had specific relevant experience, allowing this person to be assigned to a nursing situation which under normal circumstances would require the expertise of a community nurse.

In addition to the use of this instrument, it was also intended to demarcate the roles and responsibilities clearly with the assistance of job descriptions. In actual fact, only one agency had new job descriptions. However, as many community nurses and community nurse auxiliaries did not agree with parts of these job descriptions, in practice the job descriptions were not actually adhered to consistently. In one of the other two agencies, the job descriptions were to be developed and implemented during the research. However, in January 1995 they were not ready. In the integrated agency, the task and responsibilities of the community nurses and the community nurse auxiliaries did not change. There was, in fact, a new job description for the home helps, but because integration was still in an early stage of development in 1994, it scarcely played any role in practice.

The difference between the experimental and comparison groups was that in the latter, the assignment of patients took place without the use of the list of complexity criteria and job descriptions. This old situation can be described as a situation in which the assignment of patients and the division of labour between community nurses and community nurse auxiliaries was based on 
subjective/individual criteria and considerations. These criteria are not straightforward and not always clear to everyone.

As regards specialization, intervention consisted in the division of areas-ofspecial-expertise among the community nurses and the community nurse auxiliaries with their associated tasks: consultation, advice, training, instruction and, where required, the provision of technical nursing interventions; keeping one's own expertise and skills up to date; setting up and maintaining a documentation-system; participating in meetings with colleagues concerned with the same area-of-special-expertise. A number of hours per month were made available to carry out these tasks.

Although the intention was that a start be made at the beginning of 1994, this turned out in practice not always to be feasible because the assignment of the areas lasted longer than was expected or because training courses were only given late in the year. Working with areas-of-special-expertise, only began for most agencies to get under way slowly but surely in the autumn of 1994. This meant that in most cases the community nurses and community nurse auxiliaries working on a specialized basis made arrangements for their new jobs, access for their colleagues, training in their area-of-specialexpertise and for time to collect relevant professional literature and read it. In practice, people were seldom consulted by their colleagues in respect of the areas-of-special-expertise.

Within one agency, intervention was limited to the assignment of duties, after which those involved had the rest of 1994 for further orientation in respect of the circumscription of the area-of-special-expertise. As the nursing staff in this agency hardly worked with areas-of-special-expertise at all, it did not participate in the investigation of the effects on the quality of care.

The comparison group distinguished itself from the experimental group in that its carers had no tasks in respect of an area-of-special-expertise. In order to remain abreast of developments they were left to their own devices and were able to consult colleagues who did have an area-of-special-expertise (in view of the above, however, this scarcely ever happened).

\subsubsection{Research population}

Within the experimental and comparison groups, patients were approached for participation in the investigation. Community nurses and community nurse auxiliaries gave letters to their patients in which they were asked to participate in the investigation. Within the agencies where specialization was to take shape, only those patients were approached who belonged to the group for whom there was an actual area-of-special-expertise. In the first instance 262 patients responded positively in respect of participation in the research. Finally, 211 patients participated in the research. 51 patients declined to participate because of the seriousness of their illness or because 
they had been admitted to hospital, or they were not able to answer the questions by telephone because of deafness. The distribution of the respondents in the various groups, is shown in table 2 .

Table 2 Distribution of patients in the experimental and comparison groups (in absolute numbers)

\begin{tabular}{lccc}
\hline & Experimental group & Comparison group & Total \\
\hline Differentiated Practice & 46 & 38 & 84 \\
Specialization & 57 & 70 & 127 \\
Total & 103 & 108 & 211 \\
\hline
\end{tabular}

As only a few patients from some agencies took part, a comparison among the agencies was made difficult and in the analysis, emphasis will be placed on a comparison among experimental and comparison groups within differentiated practice and specialization. The random selection comprised 78 men and 133 women. Their average ages were 70.5 years for the men and 71.4 for the women (71.2 for the group as a whole). Of this group of patients, $53 \%$ were living with a partner, $40 \%$ were alone and $7 \%$ lived with their children. The experimental and comparison groups were compared for both types of differentiated practice and specialization in respect of the following characteristics: age, home situation, patients' health, type of carer providing the care, the period of time the patient had already been in care and the average number of days of care per week. As regards these characteristics, there appeared to be only one significant difference. This was that within the agencies with specialization more patients in the experimental group were cared for by the community nurse and fewer patients by the community nurse and community nurse auxiliary together. This distinction can be explained on the basis of the fact that at the time when the investigation took place, in most agencies there were only areas-of-special-expertise for community nurses.

\subsubsection{Measuring instrument}

The Van Campen of al. $(1992,1995)$ review of the literature, revealed that there was no suitable measuring instrument available to measure the quality of care from the perspective of the patient. For that reason, a new questionnaire was developed in which the nine quality aspects from table 1 (expertise, continuity, support to informal carers, humaneness, provision of information, guidance, efficacy, total load and suitability) were included and the discrepancy theory (i.e. quality is the discrepancy between expectation and observation) was applied. In order to measure the concept of quality of care as valid as possible, attention was paid to content validity. In this context, in addition to the literature mentioned above, use was made of two 
questionnaires which were recently developed for measuring the quality of care within community nursing and home help: Kwaliteitsmeting Thuiszorg [Home-care Quality Measurement] (Driessen, 1994) and the Handboek Gebruikersraadpleging [Handbook users guide] (National Association for Health Care, 1994). At the same time, use was also made of the research of Van Groen et al. (1990), Oudenampsen et al. (1993) and Van der Waal (1994). On the results of this research, a questionnaire was drawn up and assessed by a staff specialist and a quality specialist of an agency for community nursing. The reliability of the instrument was established by calculating Cronbach's alpha on the observational items $(\alpha=.83)$.

As patients of agencies for community nursing are most likely to be older people who can be expected to have more difficulty in filling in a postal questionnaire than in taking part in a oral enquiry, it was determined to deal with an interview schedule on a oral basis. In order to increase anonymity and to interview a large number of patients in a short period of time, the interview schedule was used in a telephone enquiry in the period, December 1994 to January 1995.

In the interview schedule, the expectation of the patient was operationalized by asking how important the patient found each quality aspect (the score options varied from ' $1=$ not important' to ' $5=$ extremely important'). These questions are included in table 3 . No questions are asked in this table about the three aspects that Post et al. (1993) mention in relation to 'result'. The reason for this is that it can be regarded as selfevident, and that the patient will regard the result of the provision of care being good as extremely important.

Table 3

Questions asked to determine what expectations the patients have of care

How important do you think it is that

1 the carer is an expert (expertise)

2 you are always assisted by the same carer? (continuity of carer)

3 replacement carers know what they have to do for you? (continuity of care)

4 the carer involves your immediate environment (family and friends) in the care? (support to informal carers)

5 the carer treats you as an equal? (humaneness)

6 the carer provides you with information about your illness and care? (provision of information)

7 you can talk with the carer about the consequences of your illness in everyday life? (guidance).

3 In discussing the results of this research the term carer was used consistently. It means the person with whom the client has the most to do. Depending on the client situation it can be the community nurse, the community nurse auxiliary or a home help. 
In order to gain a picture of the care provided (i.e. observation), these quality aspects have been worked into a number of specific questions in which the patient could indicate how often particular situations arose (the score options range from ' $1=$ no, never' to ' $5=$ always'). These were called 'observational items'. For example, with the relationship to expertise, the following question was asked: If you have questions, is the carer able to answer them immediately? and in respect of humaneness: Do you have the impression that the carer takes you seriously? Three or five observational items were formulated for each quality aspect.

The quality of care was then determined by using discrepancy scores on the following principle: quality of care = observation - expectation. This means that the quality of care is viewed as good if the discrepancy score is positive or 0 . The quality of care leaves something to be desired when there is a negative score. With the assistance of this calculation, a range of marginal discrepancies $(-1$ or +1$)$ to large discrepancies $(-4$ or +4$)$ was produced. Exceptions to this calculation are formed by the quality aspect known as 'result'. Since no question was asked as to the importance of this quality aspect, the discrepancy score was arrived at in a different way. The patient was asked whether he or she attached value to the care or whether it was bothersome. Then the discrepancy score was determined by comparing the answers to these questions using the following formula: quality of care $=$ no burden - benefit. In order to arrive at a general assessment of the quality of care, the patient was asked to assign a numerical grade to the provision of care and to give an opinion regarding the time at which the care took place.

\subsubsection{Analysis}

In order to give a general picture of the degree to which the various items were regarded as important and the extent to which they were also actually observed during care, 'mean scores' were presented. This allows the reader to gain broad insight into the patients' assessment of the various quality items. Then a discrepancy score is calculated between each quality aspect (= expectation) and each related separate observation item. In addition, a discrepancy score was calculated between the quality aspect and the average of the different observational items related to that aspect. In order to determine whether there were differences among the various groups of patients (experimental versus comparison group and specialization versus differentiated practice) $\mathrm{Chi}^{2}$ and non-parametric tests were carried out. The choice was made for non-parametric tests (Mann-Whitney and Kruskal Wallis) because almost all the variables were not normally distributed. 


\subsection{Results}

In this section, a description is given of the patients' assessment of the quality of care and any differences between the experimental and comparison groups. This assessment was made by using mean scores and discrepancy scores for the various aspects of quality.

Table 4 The degree to which patients view the various quality aspects as important (in average scores)

\begin{tabular}{lcccc}
\hline & \multicolumn{2}{c}{ Differentiated practice } & \multicolumn{2}{c}{ Specialization } \\
\hline Quality aspects & $\begin{array}{c}\text { Exper. group } \\
(n=46)\end{array}$ & $\begin{array}{c}\text { Comp. group } \\
(n=38)\end{array}$ & $\begin{array}{c}\text { Exper. group } \\
(n=57)\end{array}$ & $\begin{array}{c}\text { Comp. group } \\
(n=70)\end{array}$ \\
\hline Expertise & 4.80 & 4.66 & 4.68 & 4.64 \\
Continuity of carer & 3.53 & 3.76 & 3.63 & 3.57 \\
Continuity of care & 4.51 & 4.37 & 4.23 & 4.17 \\
Support to informal carers & $3.32^{*}$ & $4.00^{*}$ & 3.42 & 3.46 \\
Humaneness & 4.57 & 4.66 & 4.53 & 4.51 \\
Provision of information & 3.86 & 4.14 & 4.36 & 4.12 \\
Guidance & 4.20 & 4.05 & 4.43 & 4.53 \\
\hline
\end{tabular}

For description of quality aspects the reader is referred to table 3.

" the average scores of the experimental and comparison groups are significantly different $(p \leq .05)$.

Table 4 shows that most quality aspects are found very or extremely important by the patients (the most averages are between 4 and 5 ). The quality aspects 'continuity of carer' and 'informal care' are regarded as less important than other aspects. This means that patients find it less important that they always have the same carer and that their family/friends are involved in their care.

If the patient is asked what quality aspect he/she finds most important, then expertise scores highest $(71 \%)$. The remaining patients give priority to four other aspects: continuity $1(12 \%)$, humaneness $(9 \%)$, continuity of care $(6 \%)$ and support to informal carers (2\%). The aspects of 'information provision' and 'guidance' are not mentioned by any of the patients in answering this question.

The extent to which the above aspects are dealt with during the care, is revealed in table 5 . Here mean scores are given of the separate observational items and the mean scores of the factors, which arise by combining the observational items of each quality aspect. 
Table 5 Survey of the degree to which the quality aspects are observed by the patients during care (in average scores)

\begin{tabular}{|c|c|c|c|c|}
\hline \multirow[b]{2}{*}{ Quality aspects } & \multicolumn{2}{|c|}{$\begin{array}{l}\text { Differentiated } \\
\text { practice }\end{array}$} & \multicolumn{2}{|c|}{ Specialization } \\
\hline & $\begin{array}{l}\text { Exper. } \\
\text { group } \\
(n=46)\end{array}$ & $\begin{array}{l}\text { Comp. } \\
\text { group } \\
(\mathrm{n}=38)\end{array}$ & $\begin{array}{l}\text { Exper. } \\
\text { group } \\
(n=57)\end{array}$ & $\begin{array}{l}\text { Comp. } \\
\text { group } \\
(n=70)\end{array}$ \\
\hline Expertise: & 4.25 & 4.45 & $4.60^{*}$ & $4.40^{\star}$ \\
\hline $\begin{array}{l}\text { - he/she is always able to answer } \\
\text { the questions immediately }\end{array}$ & 4.05 & 4.28 & 4.44 & 4.25 \\
\hline $\begin{array}{l}\text { - he/she is abreast of the latest developments } \\
\text { related to my illness }\end{array}$ & 4.14 & 4.18 & 4.41 & 4.19 \\
\hline - he/she has sufficient knowledge to help & 4.27 & 4.63 & 4.47 & 4.48 \\
\hline $\begin{array}{l}\text { - he/she is able to explain clearly why } \\
\text { particular treatments are given }\end{array}$ & 4.48 & 4.56 & 4.58 & 4.43 \\
\hline - he/she is good at his/her job & 4.43 & 4.53 & 4.78 & 4.62 \\
\hline $\begin{array}{l}\text { Continuity of carer: } \\
\text { - patient is always cared for by the same carer }\end{array}$ & 2.42 & 2.55 & 2.98 & 2.61 \\
\hline Continuity of care: & 4.26 & 4.39 & 4.51 & 4.37 \\
\hline - cooperation between carers runs smoothly & 4.49 & 4.76 & 4.62 & 4.40 \\
\hline - replacements know what they have to do & 4.02 & 4.03 & 4.43 & 4.31 \\
\hline Support to informal carers & 4.00 & 3.98 & 4.01 & 4.03 \\
\hline $\begin{array}{l}\text { - he/she comes to do precisely those things } \\
\text { that family/friends cannot do }\end{array}$ & 4.20 & 4.30 & 4.36 & 4.51 \\
\hline - he/she shows interest in the family & 4.18 & 4.03 & 4.26 & 4.09 \\
\hline - he/she talks to them & 3.64 & 3.58 & 3.47 & 3.42 \\
\hline Humaneness: & 4.53 & 4.60 & 4.60 & 4.44 \\
\hline - patient is satisfied with carer's treatment & 4.76 & 4.89 & 4.82 & 4.73 \\
\hline $\begin{array}{l}\text { - heishe does not let the patient feel he is just } \\
\text { a number }\end{array}$ & 4.37 & 4.39 & 4.56 & 4.48 \\
\hline - heishe takes the patient serioushy & 4.78 & 4.97 & 4.70 & 4.75 \\
\hline - heishe provides good support & 4.40 & 4.45 & 4.50 & 4.34 \\
\hline - he/she is unhurried and has time enough & 4.13 & 4.24 & $4.40^{*}$ & $3.99^{*}$ \\
\hline Provision of information & 4,07 & 4.23 & 4.21 & 4.21 \\
\hline $\begin{array}{l}\text { - he/she takes sufficient time to explain the } \\
\text { use of medicine, injections and aids }\end{array}$ & 4.53 & 4.59 & 4.53 & 4.51 \\
\hline $\begin{array}{l}\text { - helshe explains how the treatment will } \\
\text { continue }\end{array}$ & 2.43 & 2.72 & 2.48 & 2.71 \\
\hline $\begin{array}{l}\text { - heishe can explain clearly what heishe can } \\
\text { or cannot do for the patient }\end{array}$ & 4.61 & 4.43 & 4.51 & 4.43 \\
\hline $\begin{array}{l}\text { - heishe responds to questions about the } \\
\text { prognosig in respect of the ilness }\end{array}$ & 3.81 & 4.21 & 3.94 & 3.86 \\
\hline - hershe uses understandable language & 4.67 & 4.82 & 4.82 & 4.69 \\
\hline
\end{tabular}




\begin{tabular}{lllll}
\hline $\begin{array}{l}\text { Guidance: } \\
\text { - patient talks with carer about the }\end{array}$ & 3.31 & 3.62 & 3.77 & 3.64 \\
$\begin{array}{l}\text { consequences of the illness } \\
\text { - he/she pays attention to the patients' wishes }\end{array}$ & 2.67 & 2.86 & 3.40 & 3.39 \\
- he/she talks about how to deal with the & 4.42 & 4.40 & 4.45 & 4.56 \\
$\quad$ consequences of the illness in every day life & & 3.83 & 3.26 & 3.04 \\
Result: & & & & \\
- patient benefits from the care & 4.51 & 4.68 & 4.62 & 4.58 \\
- patient does not view care as burdensome & 4.80 & 4.92 & 4.79 & 4.87 \\
\hline
\end{tabular}

the figures printed in bold are the average of the observational items together for each quality aspect.

he/she = the carer: community nurse, community nurse auxiliary or home help (dependent on the patient situation)

the mean scores are calculated as separate items which were applicable for the patient the mean scores of experimental and comparison groups differ significantly $(p \leq .05)$.

When, in the first instance, the combined factors were looked at (i.e. the figures printed bold) it appeared that most quality aspects often (score 4) or always (score 5) are present in care. In respect of continuity of carer and guidance, the quality sometimes leaves something to be desired. As regards continuity in particular, it appears that patients are often cared for by different carers. The separate observational items show that the lower score in the area of guidance is caused by the fact that during care little attention is paid to the consequences of the illness and dealing with this complaint in daily life. At the same time, the separate observational items show that the provision of information has shortcomings in respect of questions on future prospects. Where the effects of differentiated practice and specialization are looked at, these appear to be absent in respect of differentiated practice but two significant differences are found in respect of specialization (i.e. working with areas-of-special-expertise): the experimental group of patients found the carer highly expert and less hurried than patients in the comparison group.

The fact that the care received by patients is generally assessed as good, is confirmed by the numerical grades that were given: a quarter $(26 \%)$ assessed the care with a ten, a quarter (23\%) with 9 or 9.5 and $40 \%$ with 8 or 8.5 . The remaining $11 \%$ gave a 7.5 or lower for the care received. All marks are out of ten. In addition, the majority of the patients indicated that the carer often or always came on time $(77 \%)$. In $15 \%$ of the cases, the carer was sometimes on time and sometimes not and in $8 \%$ of the cases the carer was seldom or never on time. Where, finally, the question is asked as to the preferred time of the day for care, then the majority agree with the present situation: two thirds $(69 \%)$ prefer care between $8.30 \mathrm{am}$ and $10.00 \mathrm{am}, 17 \%$ between 7.00 am and 8.30 am, the remaining $14 \%$ preferred either by appointment, in the afternoons or evenings. 
After presentation of the average scores with assistance of the discrepancy scores, an attempt was made to provide more insight into the quality of care. The discrepancy scores provide the difference between expectation and observation (quality of care $=$ observation - expectation). These scores were only calculated where an answer was gained on both expectation and observation. By paying attention to the negative discrepancy scores, it became clear which aspects of the care had shortcomings. These results are described in table 6 .

Table 6 Survey of the difference between the expectation and observations of the quality aspects (in average discrepancy scores)

\begin{tabular}{|c|c|c|c|c|}
\hline \multirow[b]{2}{*}{ Quality aspects } & \multicolumn{2}{|c|}{$\begin{array}{l}\text { Differentiated } \\
\text { practice }\end{array}$} & \multicolumn{2}{|c|}{ Specialization } \\
\hline & $\begin{array}{c}\text { Exper. } \\
\text { group } \\
(n=46)\end{array}$ & $\begin{array}{l}\text { Comp. } \\
\text { group } \\
(n=38)\end{array}$ & $\begin{array}{l}\text { Exper. } \\
\text { group } \\
(n=57)\end{array}$ & $\begin{array}{l}\text { Comp. } \\
\text { group } \\
(n=70)\end{array}$ \\
\hline Expertise: & $-.59^{*}$ & $-.21^{*}$ & -.03 & -.22 \\
\hline $\begin{array}{l}\text { - he/she is always able to answer } \\
\text { the questions immediately }\end{array}$ & -.74 & -.39 & -.21 & -.39 \\
\hline $\begin{array}{l}\text { - he/she is abreast of the latest developments } \\
\text { related to my illness }\end{array}$ & -.65 & -.47 & -.27 & -.46 \\
\hline - he/she has sufficient knowledge to help & $-.53^{*}$ & $-.03^{*}$ & -.20 & -.17 \\
\hline $\begin{array}{l}\text { - he/she is able to explain clearly why } \\
\text { particular treatments are given }\end{array}$ & -.38 & -.11 & -.06 & -.20 \\
\hline - he/she is good at his/her job & -.43 & -.13 & .11 & -.03 \\
\hline $\begin{array}{l}\text { Continuity of carer: } \\
\text { - patient is always cared for by the same carer }\end{array}$ & -1.11 & -1.21 & -.65 & -96 \\
\hline Continuity of care: &. .26 & .04 & .28 & .15 \\
\hline - cooperation between carers runs smoothly & $-.02^{*}$ & $.41^{*}$ & .40 & .21 \\
\hline - replacements know what they have to do & -.49 & -.32 & .17 & .09 \\
\hline Support to informal carers & $.70^{*}$ & $-.06^{*}$ & .51 & .43 \\
\hline $\begin{array}{l}\text { - he/she comes to do precisely those things } \\
\text { that family/friends cannot do }\end{array}$ & .83 & .21 & .88 & .97 \\
\hline - he/she shows interest in the family & $.83^{*}$ & $.03^{*}$ & .85 & .58 \\
\hline - he/she talks to them & .44 & -.40 & -.04 & -.13 \\
\hline Humaneness: & -.07 & -.08 & .06 & -.13 \\
\hline - patient is satisfied with carer's treatment & .23 & .24 & .27 & .21 \\
\hline $\begin{array}{l}\text { - he/she does not let the patient feel he is just } \\
\text { a number }\end{array}$ & -.16 & -.26 & -.02 & -.09 \\
\hline - he/she takes the patient seriously & .30 & .30 & .18 & .19 \\
\hline - he/she provides good support & -.21 & -.21 & -.06 & -.19 \\
\hline - he/she is unhurried and has time enough & -.36 & -.42 & -.18 & -.54 \\
\hline
\end{tabular}


Provision of information

- he/she takes sufficient time to explain the

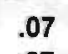

.67

$-.16$

$-.34$

26

$\cdot .34$

use of medicine, injections and aids

- he/she explains how the treatment will

continue

- he/she can explain clearly what he/she can

or cannot do for the patient

- he/she responds to questions about the

prognosis in respect of the illness

- he/she uses understandable language

Guidance:

- patient talks with carer about the consequences of the illness

- he/she pays attention to the patients' wishes

- he/she talks about how to deal with the

consequences of the illiness in every day life

Result:

- patient does not view care as burdensome $\begin{array}{llll}-1.38 & -1.39 & -1.83 & -1.40\end{array}$

$\begin{array}{llll}.67 & .26 & .22 & .34\end{array}$

$\begin{array}{llll}-.08 & -.04 & -.55 & -.43\end{array}$

$\begin{array}{llll}.80 & .68 & .47 & .55\end{array}$

$\begin{array}{llll}-1.02 & -.41 & -.72 & -.77\end{array}$

$\begin{array}{llll}-1.63 & -1.14 & -1.02 & -1.13\end{array}$

$\begin{array}{llll}.29 & .38 & -.07 & .05\end{array}$

$\begin{array}{llll}-1.49 & -.72 & -1.24 & -1.38\end{array}$

- the figures printed in bold are the average of the observational items together for each quality aspect.

- $\quad$ he/she = the carer: community nurse, community nurse auxiliary or home help (dependent on the patient situation)

- the mean scores are calculated as separate items which were applicable for the patient

* the mean scores of experimental and comparison groups differ significantly ( $p \leq .05)$.

In table 6, the discrepancy score is given per observational item and per combined factor (= the figures printed bold). The fact that many of the scores are negative shows that the expectation of the patients as regards most aspects of care is higher than the degree to which the aspects are observed. In this, we should note that in general the discrepancies are small (between -1 and 1 , with a possible maximum difference of -4 and 4). Only in a few cases, is there a clear difference between expectation and observation.

In respect of the expertise, quality leaves something to be desired when it is a question of answering questions immediately and being abreast of the latest developments. This relates in particular to the groups within which differentiated practice has taken shape. In respect of continuity, it is clear that patients are often cared for by more different carers than they would wish. With regard to the provision of information and guidance, the same items play a role as those that we looked at in the average scores (see the discussion of table 5). The data from table 6 , also make it clear that different items are more often observed in practice than those which the patient has indicated as important. These are, in particular, a number of items that relate to the quality aspects of continuity of care, support to informal carers, humaneness and the provision of information.

Comparison of the average discrepancy scores between the experimental and 
comparison groups, provided three significant differences within the differentiated practice group only:

- carers in the experimental group were viewed by patients as less expert than expected, because according to the patients they did not have the information necessary to provide good care,

- the cooperation between carers was also in view of the patients within the experimental group less good than in the comparison group,

- patients in the experimental group received more support for their family and friends than patients in the comparison group, because the carer demonstrated interest in the immediate social environment.

\subsection{Discussion}

In this chapter, we have paid attention to the effects of differentiated practice and specialization on the quality of care. The quality of care is measured from the patients' perspective by comparing the patients' expectations and observations in respect of care. Research shows that the patients find most of the quality aspects included in the research important and so they find them in the care provided. In addition, it has been shown that in various aspects there is a discrepancy between expectation and observation of the patient, where the expectation is higher than what is observed. The patients' assessment is mostly negative in respect of continuity, guidance and one information item. Although the patients do not find it terribly important that they are cared for by the same carer, they do believe that care is too often provided by different carers. In addition, the patients find it important that more attention be paid to the consequences of illness during care. In relation to the cooperation between carers, the support to informal carers and some aspects of humaneness and provision of information, the observation exceeds the expectation of the patients. In respect of these aspects, the quality is accordingly assessed as good. In general, on the basis of the numerical grades and the discrepancy scores it can be concluded that the patients assess the care they receive positively.

In relation to work-(re)design few effects were found. In respect of differentiated practice, it is in agreement with the expectation that was stated in the beginning of this chapter. However, it is precisely within differentiated practice that a number of significant differences between the discrepancy scores have been found: for example, patients in the experimental group assessed the expertise and cooperation more negatively and the support to informal carers more positively in comparison with patients in the comparison group. These differences are difficult to explain on the basis of differentiated practice. They can not be explained on the basis of a difference in effort of 
the part of the carers, because the assignment of carers to the experimental and comparison groups were the same.

In respect of specialization, differences were found that demonstrate a clearer relationship with the intervention: the community nurse and community nurse auxiliary who had been assigned an area-of-special-expertise were viewed by the patients as more expert and less hurried. It is possible that the effect was partly a consequence of the fact that, in the experimental group, more patients were assisted by community nurses who had a higher level of training than community nurse auxiliaries. However, because this distinction was not confirmed by the discrepancy scores we cannot elicit any farreaching conclusions from them.

Various reasons can be advanced for the fact that fewer effects were found as a result of differentiated practice and specialization. In the first place, it would appear from other research (for example Campen ot al., 1992, 1995) that the majority of patients, in general, have a positive assessment of the provision of care. So the margin, within which the differences between the experimental and comparison groups have to vary is very small. Although in the construction of the measuring instrument in the context of validity and reliability as much use as possible was made of existing literature on, and instruments for, the measurement of the quality of care, it is possible to increase the discriminatory capacity of the interview schedule by adjustments and/or additions.

Another cause for the fact that only few differences were found, is the early stage in which the participating agencies found themselves in respect of work(re)design at the time of the research. The implementation of differentiated practice and specialization lasted longer than was expected at the beginning of the research. As a result the research, viewed with hindsight, took place too early for us to be able to expect that the effects in respect of quality of care would be measurable in the patients. It is also possible that this is reinforced by the fact that only a few patients participated in the inquiry from some of the agencies. In these agencies there should be significant differences between only a small number of patients. It would therefore be better to look upon the results of this research as pre-measurements and to repeat the investigation within the agencies concerned at a later date. It is then possible that the effects of differentiated practice and specialization would be observed.

In any event the research made it clear that by means of a comparison between the expectation about care ( $=$ the degree of importance) and the observation of care (= the degree of presence) a picture can be gained of the subjective standard on the basis of which the patient assesses the quality of care. 


\subsection{References}

Aast M.M.G. van de, Boumans N.P.G. \& Landeweerd J.A. (1995). Correlaten van de kwaliteit van de verpleegkundige zorg. De relatie tussen de kwaliteit van de verpleegkundige zorgverlening enerzijds en de stressbeleving, tevredenheid van patienten en tevredenheid van verpleegkundigen anderzijds (The relationship between quality of nursingcare and stressexperience, patientsatisfaction, and satisfaction among nurses). Verpleogkunde (2), 71-82.

Bleys C. (1986). Over de grenzen van de zorg vanuit een klinisch oogpunt (About the boundaries of care from a clinical point of view). Scripta Modico-Philosophica (2), 14-28.

Campen C. van, Friele R.D. \& Kerssens J.J. (1992). Methods for assessing patient satisfaction with primary care review and annotated bibliography. NIVEL bibliography no. 35 . Utrecht: NIVEL.

Campen C. van, Sixma H., Friele R.D., Kerssens J.J. \& Peters L. (1995). Quality of Care and Patient Satisfaction: a Review of Measuring Instruments. Modical Care Research and Review 52(1), $109-133$.

Driessen C. (1994). Kwaliteitsmeting Thuiszorg (Home-care Quality Moasurement). 'sHertogenbosch: Unie van Katholieke Bonden van Ouderen (KBO).

Dutch Organisation for Scientific Research (1992). Onderzooksprogramma kwaliteit van Zorg 1992-1996 (Research-programme Quality of care 1992-1996). Nederlandse organisatie voor Wetenschappelijk Onderzoek, gebied medische wetenschappen.

Fishbein M. \& Ajzen I. (1975). Belief, Attitude, Intention and Behavior: an Introduction to Theory and Research.

Groen B., Willemse N. \& Rijkschroeff R. (1990). Op zoek naar kwaliteitscriteria van de eerstelijnsgezondheidszorg vanuit het patientenperspectief (Searching for criteria for quality of extramural health care from the patient's perspective). Utrecht: Landelijk Overleg van Decentrale Patienten/Consumenten Platforms (LODEP).

Harteloh P.P.M. \& Casparie A.F. (1991). Kwaliteit van zorg. Van een zorginhoudelijke benadering naar een bedrijfsundige aanpak (Quality of care. From a care-approach to a business-approach). 's-Gravenhage: Vuga/De Tijdstroom.

Linder-Pelz S. (1982). Toward a theory of patient satisfaction. Social Science and Modicine 16, 577-582.

National Association for Health Care (1994). Handboek gebruikersraadpleging (Handbook users guide). Bunnik: Landelijke Vereniging voor Thuiszorg.

National Council for Health Care. Verplogkundig Beroepsprofiel (Nursing Profile). Zoetermeer: National Council for Health Care

Oudenampsen D., Rijkschroeff R. \& Venne L. van de (1993). Kwaliteitscriteria van de eerste lijn on kwaliteitsbevordering door de decentrale patientenplatforms (Criteria for quality for extramural care and quality improvement by local patient-organizations). Amsterdam: Stichting Kohnstamm Fonds voor Onderwijsresearch SCO, 1993.

Ovretveit J. (1992). Health Service Quality: An Introduction to Quality Methods for Health Services. London: Blackwell Scientific.

Parasuraman A., Zeithaml V.A. \& Berry L.L. (1985). A conceptual model of service quality and its implications for future research. Joumal of Marketing 49, 41-50.

Post M.W.M., Arend I.J.M. van den, Dingemans P.J.M., Haas C.L. de, Horn G.H.M.M. ten, Linden B.A. van der, Londen J. Van, Schrijvers A.J.P., Staring M.A.T.M. \& Weert-Van Oene G.H. de (1993). Kwaliteit van de zorgverlening: het patientenperspectief (Quality of care: patient's perspective). Kwaliteit on Zorg (2), 50-60.

Health Research Council. Advies kwaliteit ven zorg. Terreinverkenning en prioriteiten voor wetenschappelijk onderzook (Advise quality of care. A reconnaissance and prionities for scientific research). 's Gravenhage: Health Research Council. 
Pascoe G.C. (1983). Patient Satisfaction in Primary Health Care: a Literature Review and Analysis. Evaluation and Program Planning 6, 185-210.

Sixma H.J., Kerssens J.J., Campen van C. \& L. Peters (in press). Quality of care from the patients' perspective: a theoretical approach.

Strasser S., Aharony L. \& Greenberger D. (1993). The patient satisfaction process: moving toward a comprehensive model. Modical Care Review 50(2), 219-248.

Tempelman C.J.J. (1987) Welbevinden bij ouderen: constructie van een meetinstrument (Welbeing among the elderly: construction of a measuring instrument). Groningen: Rijksuniversiteit Groningen.

Waal M.A.E. van der, Nievaard A.C. \& Casparie A.F. (1994). Patientenraadpleging bij twoe gezondheidscentra in Rotterdam (Consultation of patients in two health caro agencies in Rotterdam, The Netherlands). Rotterdam: Instituut Beleid en Management Gezondheidszorg.

Verheij R.A.,Caris-Verhallen W.M.C.M. \& A. Kerkstra (1993). Integratie kruiswerk on gezinsverzorging. Ervaringen van hulpverteners en clienten (Integration of community nursing en home help services. Experiences from carers and clients). Utrecht: NIVEL. 


\subsection{Appendix Definitions of quality aspects (Post et.al., 1993)}

\section{Structure}

1 Availability:

The degree to which suitable care is available for the patient/consumer (also waiting lists, waiting time, indication criteria, costs, etc.) (this definition also includes the NWO-aspect of accessibility).

2 Accessibility:

The physical and geographical accessibility of care, including the required equipment, access to buildings, etc.

3 Accommodation:

The degree to which the patient/consumer views the institution or organization is suitable for the care to be provided in a physical sense, in particular in respect of the ambience (space, colours, comfort) hygiene, (fire)safety and physical privacy.

Technical aspects

4 Assessment:

The accuracy and speed with which the assessment is established (this definition includes the aspect of 'avoiding unnecessary care' defined by the Dutch Organisation for Scientific Research).

5 Expertise:

The degree to which the professional applies the necessary knowledge and skill required for the practice of the profession in the right way (this definition also includes the aspects of 'expertise, suitability, safety and hygiene' defined by the Dutch Organisation for Scientific Research).

6 Continuity:

The number of carers with whom the patient has to do or has had to do, the degree to which the care provided by the various professionals care is consistent and the degree to which attention is paid to the transfer of the treatment (in the case of several carers, their replacement of succession).

7 Nutrition:

The degree to which the indicated or agreed nutrition is arranged for and the quality of this nutrition (temperature, taste, manner in which served, etc.).

8 Support to informal carers:

The degree to which sufficient care and support in the home setting is available, and this informal care is supported by the professionals. 
9 Humaneness:

The degree to which the professional views the patient/consumer as an equal human being and takes his dignity and personal responsibility as a basic principle (this definition also includes the aspects 'cooperation, independence, involvement of the patient and promotion of self care' defined by the Dutch Organisation for Scientific Research)

10 Provision of information:

The degree to which the professional provides the relevant information to the patient/consumer and where necessary his immediate environment, both at his own initiative and when asked (this definition also includes the aspects of 'preparedness for responsibility and involvement of the patient' defined by the Dutch Organisation for Scientific Research).

11 Guidance:

The degree to which the professional is able to sympathize with the position of his/her patient/consumer and not only as regards the treatment of the illness, but also the patient.

12 Privacy:

The degree to which the personal environment of the patient is respected and the confidentiality is respected (this definition also includes the aspect of material privacy defined by the Dutch Organisation for Scientific Research).

Results

13 Efficacy:

The degree to which the care actually improves the state of health, or the halts delays.

14 Total load:

The degree to which the patient/consumer is burdened in his/her total functioning (physical, psychological, social) by the care provided, including any side effects.

15 Suitability:

The relationship between the efficacy of the care and the total load of the patient/consumer as a result of that care. 


\section{GENERAL CONCLUSIONS AND DISCUSSION}

The previous chapters have described differentiated practice and specialization (i.e. areas-of-special-expertise) in several of their aspects and have shown that implementation of these approaches incorporates important changes for community nurses and community nurse auxiliaries. To this end this dissertation has addressed eight research questions. In this final chapter the answers to the research questions are first summarized. In addition, the methods used are considered critically and theoretical reflections are made. Based on this, implications for the practice of community nurses and nurse auxiliaries are discussed and recommendations for future research are made.

\subsection{Conclusions}

This dissertation addresses eight research questions, the results of which will be presented in this section.

1. What are the differences in nursing performance between community nurses and community nurse auxiliaries in the Netherlands and to what extent are their roles specialized?

The study showed clear differences between community nurses and community nurse auxiliaries with respect to the assessment and the formulation of nursing diagnoses. These activities are restricted to community nurses. The complexity of care is considered as an important distinguishing characteristic for patient assignment to nurses or nurse auxiliaries, in the sense that complex care has to be delivered by community nurses. However, in practice, appropriate criteria for determining the degree of complexity are not commonly available for use.

Furthermore, community nurses and nurse auxiliaries perform many identical tasks: in almost all agencies community nurses regularly perform tasks not requiring their level of training, whereas in one third of the agencies nurse auxiliaries perform tasks that require the level of a community nurse. These results may be due to the lack of clearly demarcated job descriptions and to the fact that in most agencies more community nurses are employed than community nurse auxiliaries.

On the other hand, community nurse auxiliaries often do work that could be done by certified home helps. The main reasons for this include the shortage of home helps, the long waiting lists for home help services, and a lack of 
clarity about the difference between the domain of home help and community nursing.

Traditionally there was also another difference between community nurses and nurse auxiliaries. Community nurses received training in both adult care, and preventive mother and child health care, whereas nurse auxiliaries were trained to care for the elderly only. However, this variety in the work of first level nurses is diminishing: the all-round-concept is being abandoned and community nurses have to choose either mother and child health care or adult care.

In addition, there is an increasing interest in giving both community nurses and nurse auxiliaries the opportunity to specialize in a specific patient category. Agencies are trying to improve the professionalism of community nursing by means of so-called areas-of-special-expertise. Within one of these areas a community nurse (auxiliary) follows an education program/course of study, gets special on-the-job training, keeps up to date with all the new developments, and attends educational programs to stay abreast of trends and innovations on these issues. Subsequently, in her team and agency she can be consulted by her peers for knowledge or skills. In addition to this special expertise, this nurse performs the general tasks within community nursing. With the introduction of areas-of-special-expertise, a distinction should be made between areas for community nurses and areas for community nurse auxiliaries based on the complexity of care (e.g. caring for a patient with cancer requires more complex nursing interventions than caring for an incontinent patient).

In summary, there is a lack of clarity about the difference between the two types of nurse. Complexity of nursing care is seen as an important distinguishing characteristic in assigning patients either to a community nurse or a nurse auxiliary. As regards specialization, an increasing interest exists in 'areas-of-special-expertise'.

\section{What criteria are used to design an appropriate mix of staff, in what way is specialized nursing knowledge available, and how effective are these methods?}

The review of the literature showed differentiation between at least two types of nurse based mainly on education, complexity of nursing care and experience (i.e. junior versus senior). Positive effects of differentiated practice on job satisfaction, especially for the first level nurses, and on the quality of care were reported. However, the literature contained mainly job descriptions and general considerations, whereas only a few projects studied the outcomes of differentiated practice systematically and consistently. 
As regards specialization, the review shows that specialized care is mostly delivered by clinical nurse specialists (CNSs). However, community nurses are not always satisfied with a specialist working beside them and believe that they can deliver specialist care to a certain extent when they are given the opportunity (e.g. time and training). The development of areas-of-specialexpertise may be an answer to this problem. In the Netherlands, these areas have been developed to give community nurses and nurse auxiliaries the opportunity to improve their specialized knowledge. But, because these areas are a relatively new concept, the review of the literature did not yield many researchbased results in this field.

The review revealed a paucity of information about the outcomes on job characteristics, job satisfaction and burnout among community nurses and community nurse auxiliaries for both differentiated practice and specialization. As regards quality of care even less information was available. Consequently, the review resulted in a research model to study the outcomes of both principles systematically.

3. What are the differences in job characteristics, individual characteristics, job satisfaction and burnout between community nurses and community nurse auxiliaries?

Results showed several significant differences in job and individual characteristics between these two types of nurse. These differences show on the one hand that the content of the work of community nurses is more attractive (they have higher scores on skill variety and task identity) but, on the other hand, nurses feel more often isolated (they experience more time pressure, they receive less feedback and experience less support from their head nurse).

The scores on job satisfaction showed that both community nurses and nurse auxiliaries are moderately satisfied with their jobs. These scores are comparable with the results of a study among nurses working in Dutch hospitals (Boumans, 1990) and in community nursing in the United Kingdom (McGrath ot al., 1989; Wade, 1993). When the nurses and auxiliaries are compared, the results showed that community nurses are less satisfied with their work in general, their head nurse, task-clarity, and opportunities for growth at work. Furthermore, community nurses manifest more feelings of burnout. The difference in satisfaction between the two types of nurse is consistent with the result of the meta-analysis of Blegen (1993) that nurses with a higher level of education are less satisfied with their work. The lower scores on job satisfaction and more feelings of burnout among community nurses probably also reflect the issue that was mentioned in the first research 
question: most patients require basic care requiring basic expertise that can be delivered by community nurse auxiliaries. However, most agencies still employ more community nurses than nurse auxiliaries. Consequently the community nurses perform a lot of tasks below their level of training and skill and it is not always obvious when the specific expertise of a nurse is required.

These results show that at the beginning of the study the work of community nurses and community nurse auxiliaries differed on some aspects. In other words, to a certain extent differentiated practice had already been implemented.

\section{Which job characteristics and individual characteristics affect job satisfaction and burnout among community nurses and community nurse auxiliaries?}

Several job characteristics were shown to be related to job satisfaction and burnout. Job satisfaction is positively affected by task clarity, skill variety, growth at work, feedback, and task significance (= the degree to which the job has a substantial impact on the lives of other people in the immediate organization and in the world at large). These effects are consistent with other studies (e.g. Boumans, 1990; Blegen, 1993).

In our study autonomy was not significantly related to job satisfaction. The reason for this could be that nurses working in the community are relatively autonomous and therefore this characteristic is not so important for job satisfaction. This explanation is supported by the study of Parahoo and Barr (1994): autonomy was listed by only 8 of the 35 community nurses as factor that contributes to job satisfaction.

As regards burnout, time pressure was found to increase feelings of burnout, whereas burnout is decreased by autonomy, skill variety, growth at work and task significance. The effect of time pressure and autonomy is supported by other studies (Siefert et al., 1991; De Jonge et al., 1994; De Jonge, 1995). If the differences in mean scores on these characteristics are taken into account, it seems that the increased feelings of burnout among nurses compared with nurse auxiliaries can be explained by the greater pressure of time they are under.

Job satisfaction and burnout are also determined by individual characteristics. With exception of preference for career and a passive approach to coping with problems, all the individual characteristics studied have a positive influence on job satisfaction and decrease feelings of burnout. The social support experienced at work in particular is important in increasing job satisfaction and decreasing burnout. The effect of the coping-strategy is consistent with the studies of Hare et al. (1988), and Boyle et al. (1991) and 
the importance of social support received at work is supported by the studies of Hare et al. (1988), McGrath et al. (1989), Boumans (1990). Boyle et al. (1991), and De Jonge (1995). Besides, this support experienced from the head nurse in case of decreasing feelings of burnout was shown to be more important for nurse auxiliaries than for community nurses.

In addition, the results showed that job satisfaction is affected to greater extent by job characteristics, whereas burnout is more influenced by individual characteristics.

\section{How can patient-assignment be based on the complexity of nursing care in a valid and reliable way?}

The definition of Verran \& Reid (1987) was used to describe complexity as a concept: nursing care is considered complex when the degree of routine, uniformity and predictability is low and special knowledge is necessary to deliver care. The critical determinant of complexity is the extent to which knowledge is required to effectively apply interventions in the delivery of nursing service (Verran \& Reid, 1987). Thus, complex nursing situations demand specific expertise and skills.

In order to cover the total area of nursing, the instrument for patientassignment was based on a theoretical framework. The most suitable framework which provided the underpinning for developing the instrument is based on the work of Fawcett (1989). Fawcett analyzed several nursing models and concluded that considerable agreement exists on the central concepts of the discipline of nursing: health status (well and/or ill), person (the patient), environment (patient's significant others and the setting), and nursing activities (Fawcett, 1989). The instrument for patient-assignment includes these four concepts.

This instrument was shown to have acceptable levels of validity and reliability. The validity can be improved by including one aspect: psycho-social support for the patient. In addition, the results showed that the instrument can be used in nursing practice (clinical utility). As regards the acceptability both positive and negative feelings were expressed. Some appreciated the fact that the instrument clarified patient assignment, whereas others found it difficult to justify why they judged nursing situations as complex or notcomplex.

\section{To what extent is patient-assignment in community nursing congru- ent with the complexity of nursing care?}

The instrument described earlier was used to utilize nursing personnel more effectively. Usage of this instrument in nursing practice showed that staffing is not congruent with the complexity of nursing situations. Information derived 
from the instrument revealed that non-complex nursing care is needed in the majority of nursing situations. In these situations the level of a community nurse auxiliary (i.e. second level nurse) is requested. However, in most agencies for community nursing more community nurses (i.e. first level nurses) are employed than nurse auxiliaries. Thus, there is a shortage of the number of community nurse auxiliaries and an overabundance of community nurses. In interpreting this result it is important to know that, up to a few years ago, Dutch agencies for community nursing had to meet certain 'requirements of acknowledgement'. One of these requirements was the ratio of 3 community nurses to 1 community nurse auxiliary. Undoubtedly, the present ratio is a consequence of this and can not be changed immediately. Research by Verheij \& Kerkstra (1992) showed a comparable ratio in Norway and Finland, but relatively more second level nurses (i.e. community nurse auxiliaries) in Belgium and France.

\section{What are the effects of differentiated practice and specialization} (i.e. areas-of-special-expertise) on job characteristics, job satisfaction and burnout among community nurses and community nurse auxiliaries?

With respect to differentiated practice no obvious effects were found concerning changes in job characteristics, job satisfaction and burnout. As regards specialization (i.e. areas-of-special-expertise) positive effects were found. Community nurse (auxiliaries) working with areas-of-special-expertise perceived less time pressure, more growth at work and more feedback than non-specialized nurses (auxiliaries). This results in a higher level of job satisfaction. Although this was not one of the research questions, the data of this study also showed that all the community nurses and community nurse auxiliaries became less satisfied and showed more feelings of burnout in a period of one year.

\section{What are the effects of differentiated practice and specialization} (i.e. areas-of-special-expertise) in community nursing on the quality of care viewed from the perspective of the patient?

In relation to both types of work-(re)design few effects were found. As regards differentiated practice, after implementation patients assessed the expertise and cooperation more negatively and the support to informal carers more positively. These differences are difficult to explain on the basis of differentiated practice. Since differentiated practice has more consequences for the assignment of personnel (i.e. efficiency on an organizational level) than on the quality of care (i.e. patient-level) it is not surprisingly that only few effects were found. 
In respect of specialization, differences were found that demonstrate a clearer relationship with the intervention: the community nurse and community nurse auxiliary who had been assigned an area-of-special-expertise were viewed by the patients as more expert and less hurried. However, because this distinction was not confirmed by the discrepancy scores we cannot elicit any far-reaching conclusions from them. It is possible that the effect was partly a consequence of the fact that, in the experimental group, more patients were assisted by community nurses who had a higher level of training than community nurse auxiliaries.

\subsection{Discussion}

\subsubsection{Methodological reflections}

The design of the study to measure the effects of differentiated practice and specialization can be considered as pre-test/post-test quasi experimental: a study in which subjects cannot be randomly assigned to an intervention, although the researcher does manipulate the independent variable and exercises certain controls to enhance the internal validity of the results (Polit \& Hungler, 1987). An experimental and comparison group were formed. The term comparison group is used instead of control group because the study did not use a true experimental design.

In three agencies for community nursing, differentiated practice was implemented in separate teams (the experimental group). In all the agencies a comparison group was formed by other comparable teams. Nurses and nurse auxiliaries from the comparison group were not familiar with the workmethod (i.e. differentiated practice) used in the experimental group. With regard to specialization (i.e. areas-of-special-expertise), it was not possible to make a strict separation between the experimental and comparison group. Nurses in the experimental group who were entitled to an area-of-specialexpertise were selected based on specific criteria, namely motivation to specialize, hours of employment and experience. This means that specialized and non-specialized nurses were working together in the same team.

The great strength of quasi-experiments lies in their practicality, feasibility, and, to a certain extent, their generalizability. In the 'real world' it is often quite impractical, if not impossible, to conduct true experiments. However, it is less easy to prove that the experimental manipulation is the only explanation for the observed results because of other influences (Polit \& Hungler, 1987). For example, the fact that specialized and non-specialized nurses were working together in one team may have had consequences for the comparison group. By seeing the positive changes in task performance of specialized nurses, it is possible that the non-specialized nurses have 
adopted a more negative approach to their jobs. Campbell \& Stanley (1963) have grouped such competing explanations, referred to as 'threats to internal validity', into several classes. Three of them will be discussed here: selection, history and mortality/attrition.

The threat of selection encompasses biases resulting from pre-treatment differences between experimental and comparison groups (Polit \& Hungler, 1987). With regard to differentiated practice, these groups were formed by selecting some comparable teams (with regard to e.g. mix of staff) in each agency. Statistical analyses showed only one difference: community nurses and nurse auxiliaries in the experimental group were employed a little longer than the comparison group. However, when this variable was used as covariate in the analysis no changes in the results were found. Thus, the difference in years of employment did not bias the results.

A different selection procedure was used with regard to specialization. As described above community nurses and nurse auxiliaries had to meet some selection criteria in order to become participants in the experimental group. As a result, the respondents in the experimental group were motivated to work with areas-of-special-expertise, were employed for more hours and had more experience in community nursing. When hours of employment were controlled for in the analysis, the overall effect remained. As regards motivation and experience, no control was possible. However, it is plausible to attach the differences in job satisfaction to the changing of job characteristics by the implementation of areas-of-special-expertise, and not to the difference in motivation and experience. The results in chapter four showed that several job characteristics affect job satisfaction, and chapter six showed that some of these characteristics changed in favour of the experimental group.

With respect to the threat of selection an additional comment is made concerning the measurement of quality of care from a patients' perspective. Although the patients participating in this study were comparable on several characteristics it is possible that there were some unknown pre-treatment differences (a detailed description of these patients was absent). In addition, patients participated on a voluntary basis. Therefore, the opinion about the quality of care may be a selective one.

The threat of history refers to the occurrence of events, external to the intervention, that take place concurrently with the experiment and that can affect the dependent variables (Polit \& Hungler, 1987). This study was conducted in a period of great change within community nursing: the improvement of productivity, flexibility, efficacy and quality. The Dutch government introduced more competitive elements in community nursing which agencies had to anticipate. These changes resulted in a chaotic environment. An attempt was made to minimize the effects of this situation by 
selecting both an experimental and comparison group in each agency for community nursing. Possible confounding factors in the surroundings were the same for both the experimental and comparison group. Besides, we have tried to postpone implementation of other changes in the experimental and comparison groups as much as possible in order to insure the presence of some stability. It can therefore be stated that the experimental and comparison group differed only on one aspect, i.e. the intervention. Thus, if changes are seen within both groups on the same aspects it is obvious that these changes are not a consequence of the intervention. The decreased levels of job satisfaction and increased levels of burnout (chapter 6, table 5) could be due to the effect of changes in the surroundings.

At last mortality or attrition is seen as a threat to internal validity. It refers to the differential loss of subjects from the experimental and comparison groups. The loss of subjects may differ from one group to another because of a priori differences in interest, motivation, and the like (Polit \& Hungler, 1987). To a certain degree this has been the case in this study. On the pre-test $89 \%$ of the experimental group responded and $83 \%$ of the comparison group; for the post-test the percentages were respectively $70 \%$ and $59 \%$. It is plausible that the comparison groups have become more reluctant to complete a post-test questionnaire as they had no particular commitment to the study. With respect to specialization, the work did not really change for the comparison group. During the study they had the option of consulting colleagues with an area-of-special-expertise. In addition to this, nothing changed for them, but they saw the work of specialized colleagues becoming more attractive. This may be the explanation for the difference between the response on pre- and post-test between the experimental group and comparison group.

With respect to differentiated practice, the opposite was seen. The experimental group had a lower response (pre-test $83 \%$, post-test $57 \%$ ) compared to the comparison group (pre-test $98 \%$, post-test $78 \%$ ). A reason for this may be the experience with the instrument for patient assignment. Some participants in the experimental group did not appreciate the use of this instrument. As a result they might not have been willing to fill out a post-test questionnaire.

Attrition was studied by comparing the community nurses and nurse auxiliaries who responded both on the pre- and post-test (= response group) and the ones who responded only once (= non-response group). The results showed the non-response group to be less positive about some aspects of their work. The response-rates presented above showed a higher nonresponse in the comparison group as regards specialization; as regards differentiated practice there was more non-response in the experimental group. If this is combined with the fact that the non-respondents were less positive about their work, it can be concluded that in case of a $100 \%$ 
response-rate the effects of specialization would have been more positive and the effects of differentiated practice less positive.

In addition to the three threats (selection, history and mortality/attrition) some other methodological comments are made. The first concentrates on the intervention. Differentiated practice is a type of work design and is based in this study on two components: the use of job profiles and an instrument for patient assignment. However, in only one of the three participating agencies new profiles were introduced, whereas the other agencies relied on job profiles that already existed in the agency. In other words, the intervention with regard to differentiated practice concentrated on the use of the instrument for patient assignment. Therefore, the effects that were found after implementation of differentiated practice are mainly a consequence of the use of this instrument.

An additional comment is made about the moment the post-test took place. In this study the post-test was held one year after the pre-test. In the meantime an intervention was planned. The interventions were supposed to be implemented immediately after the pre-test. However, the agencies needed more time than expected for preparation. As a result, at the moment the posttest was held both types of work-redesign had not been completely crystallized in nursing practice. As a consequence in some agencies the posttest took place too early to study the effects properly. This refers in particular to specialization because of the training programs the nurses had to complete.

In addition, the same arguments are applicable to measuring the quality of care from a patients' perspective. One year is a too short time period to measure any effects among patients. A longer time span is preferable. It would therefore be better to look upon the results of this research as premeasurements and to repeat the investigation within the agencies concerned at a later date. It is then possible that the effects of differentiated practice and specialization on the quality of care would be observed in a better way.

In this dissertation several existing questionnaires were used that are largely accepted and showed acceptable levels of reliability and validity in many previous studies. To characterize nursing roles in terms of job characteristics the Boumans questionnaire was used (Boumans, 1990), that was based on the Job Diagnostic Survey (Hackman \& Oldham, 1980) and the studies by Algera (1981) and Algera et al. (1986). To measure coping strategies the Utrecht Coping List (UCL) (Schreurs et al., 1988) was used. Social support experienced at work was measured by the Organizational Stress Questionnaire (VOS-D) (Bergers ot al., 1986). Finally, burnout was measured 
using the Dutch version of the Maslach Burnout Inventory (MBI-NL) (Schaufeli and Van Dierendonck, 1994).

The above questionnaires were combined in one questionnaire, that had to be filled in by the community nurses and nurse auxiliaries. This incorporates a central methodological question: is it right to measure subjective job characteristics (i.e. as measured by employees) instead of objective job characteristics (i.e. as measured by others), since it heightens the chance of common method variance between independent and dependent variables. In other words, if job characteristics as well as reactions (such as job satisfaction) are judged by the employee himself and by means of the same questionnaire, the relation between (subjective) job characteristics and their (subjective) reactions could be overstated.

Several (meta-analytic) studies paid attention to this topic (e.g. Algera, 1981, 1983; Fried \& Ferris, 1987; Jenkins et al., 1983; Glick et al., 1986) and showed considerable agreement between the perception of job characteristics by employees themselves and the perception by others (e.g. managers). Therefore, scores on job characteristics by employees can be used as independent variables to study the relation with dependent variables such as job satisfaction and burnout. For an extensive review of several studies concerning this topic is referred to Boumans (1990), Boumans \& Landeweerd (1993), Algera (1993) and De Jonge (1995).

Because it can not be entirely excluded that the relations between subjective job characteristics and outcome variables are affected by common method variance, different response formats were used to reduce this problem.

\subsubsection{Theoretical reflections}

In this paragraph three concepts are addressed theoretically at first: differentiated practice, specialization and complexity of nursing care. After this the research model (including job characteristics, job satisfaction, and burnout) and the concept quality of care will be discussed.

The concepts of differentiated practice and specialization (i.e. areas-ofspecial-expertise)

In this study differentiated practice was described as a method to utilize available nursing personnel more effectively. Based on the premise that individual practitioners with different types of education, competence, and experience should not be used interchangeably, differentiated practice seeks to ensure that the work of nurses is carried out by the most appropriate nurse in the most appropriate way (Boston, 1990). Differentiated practice is a personnel deployment model in which the roles of nurses are (re)defined based on education, experience and competence (Murphy \& DeBack, 1990). It seeks to ensure an appropriate mix of staff to deliver common community 
nursing care. By means of specialization care is delivered to patients with a specific demand, necessitating advanced nursing knowledge and skills in order to meet the changing and increasing complexity of community nursing care.

In terms of Mintzberg (1983) both concepts are a method of specializing jobs. Differentiated practice relates to 'depth', to the control over the work; the performance of the work is separated from its administration (i.e. vertical specialization). Areas-of-special-expertise concern 'breadth' or 'scope': how many different tasks are there in each job and how broad or narrow is each of these tasks (horizontal specialization) (Mintzberg, 1983). Jobs are specialized horizontally by particularizing tasks within jobs arose from the vertical specialization.

With respect to these theoretical definitions this study has yielded more detailed information about these concepts in community nursing practice. As regards differentiated practice, the work of community nurses contains more 'depth' or control by having more skill variety, more task identity, more time pressure and less feedback. Having less feedback is a consequence of the broader area of responsibility compared to community nurse auxiliaries. In addition to these job characteristics, differentiated practice was conceptualized by making a difference between complex and non-complex nursing care. The complexity-concept clarified the 'depth' of differentiated practice by pointing to aspects in nursing situations demanding for a specific level of education and experience in order to be able to perform the corresponding nursing intervention (i.e. deliver complex nursing care).

By means of areas-of-special-expertise, a new dimension was given to the concept of specialization in addition to the already existing clinical nurse specialists. This new type of specialization widened the 'breadth' or 'scope' of the work of community nurses (auxiliaries) by adding several activities (e.g. by attending educational courses, giving consultation and instruction to colleagues, and participating in special meetings). In terms of job characteristics, the-areas-of-special-expertise incorporate more options for growth at work, more feedback and less time pressure. The difference between areas-of-special-expertise and clinical nurse specialists lies in education and nursing practice. Clinical nurse specialists are educated on a higher level (college or university) compared with the nurses with an area-ofspecial-expertise (who specialized via practical training). In addition, clinical nurse specialists only work with a specific patient population; whereas the community nurse (auxiliaries) with an area-of-special-expertise combines these tasks with general nursing duties. Both types of specialization can exist together. The areas-of-special-expertise focus on basic job enrichment, for 
community nurses and community nurse auxiliaries. The clinical nurse specialist has to facilitate this kind of specialization. For example, by means of training programs, harmonization between the areas-of-special-expertise, and product-development.

It is important to note that differentiated practice and areas-of-specialexpertise are not two separate entities. A harmonization between the two is desired in order to clearly distinguish, based on job profiles and on the complexity of care needed by the patient population, which type of nurse is needed. Therefore, a distinction has to be made between areas for first level nurses and areas for second level nurses depending on the nature of the interventions that have to be performed.

The concept of complexity of nursing care

When nursing profiles are studied one of the basic distinctions between first level and second level nurses is the complexity of decision-making (Primm, 1986; National Council for Health Care, 1988; Malloch et al., 1990). Although 'complexity' is mentioned specifically in job descriptions, this dimension is not always actually used in nursing practice. In order to clarify the fundamental difference between community nurses and nurse auxiliaries in this study, the concept 'complexity of nursing care' has been extensively described. An instrument was developed to measure the complexity of nursing care based on Verran \& Reid (1987), Fawcett (1989) and several existing instruments (e.g. Vrielink, 1990; Derckx et al., 1992; Van Til et al., 1994).

From a theoretical point of view, in this dissertation a transparent distinction is made between the complexity of nursing situations and the complexity of nursing care. The nursing situation encompasses the patient, his health status and the environment he is in. In these three components of the nursing situation aspects can be present asking for complex nursing care: i.e interventions that require expertise in diagnostics, psycho-social support and specific technical nursing interventions. When the degree of routine, uniformity and predictability to perform these interventions is low, complex nursing care falls under the jurisdiction of community nurses.

A difference between this and other existing instruments focuses on the determination of complexity. In other instruments, a higher score on several points (i.e. situation and interventions together) means that the situation is more complex. The instrument developed in this study is based on the principle that one intervention in itself can already be considered complex (e.g. providing terminal care or mental support to informal carers). The best way to determine complexity is a debatable issue. The study by De Boer (1995) compared the instrument used in this dissertation with the scoring- 
instrument developed by Van Til (1993). The results showed that both instruments lead to comparable outcomes; but, as regards practicability, the instrument developed in this dissertation was assessed less positively (De Boer, 1995). Consequently, it would seem worthwhile to look carefully at both types of instrument to develop an instrument that meets both theoretical transparency as well as sufficient practicability for use in nursing practice.

\section{Research model}

Because of the link with work redesign, the Job Characteristics Model (Hackman \& Oldham, 1975, 1976, 1980) was used as theoretical framework for this study. A research model based on this was developed to study the effects of differentiated practice and specialization. Results from other studies concerning the Job Characteristics Model (e.g. Roberts \& Glick, 1981; Algera, 1983; Broadbent, 1985, Boumans, 1990), and literature about differentiated practice, specialization, job satisfaction and burnout have resulted in the model presented in figure 1.

Figure 1 Model used to evaluate the effects of work redesign (differentiated practice and specialization) in community nursing

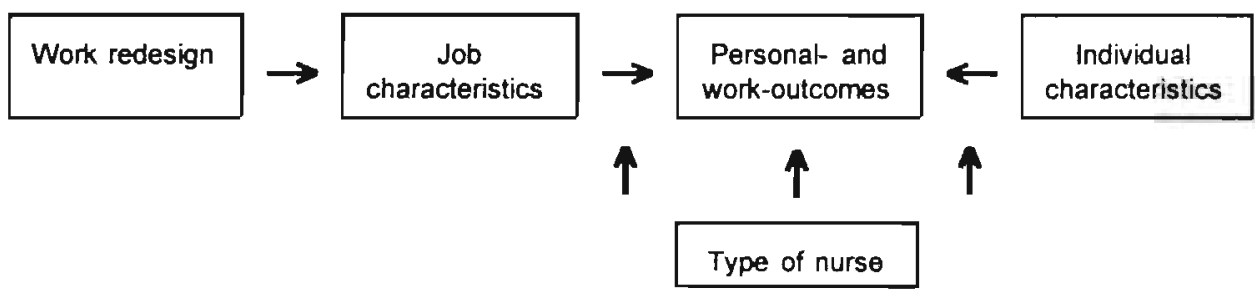

First, attention is paid to the results that supported this research model, subsequently some critical comments are made. The results showed that several job characteristics and individual characteristics (including type of nurse) affect job satisfaction and burnout. In addition to direct effects from these characteristics on job satisfaction and burnout, support was found for one moderating effect derived from the type of nurse: with respect to burnout, it is more important for community nurse auxiliaries to experience support from their head nurse than it is for community nurses.

In addition, the results in this study showed that job satisfaction is affected to greater extent by job characteristics, whereas burnout is more a result of individual characteristics. In line with this, work redesign (i.e. changing job characteristics) has a significant effect on job satisfaction, and not on burnout. Finally, the model was supported by the difference in content between the two types of work redesign. As regards differentiated practice the intervention focused mainly on the use of an instrument for patient assignment. The job profiles for most community nurses and nurse auxiliaries did not change. In line with the research model, no significant differences were found on job 
characteristics (with the exception of task significance), job satisfaction and burnout. The intervention in the specialization-group however, enclosed activities that have an impact on the job content. In line with the research model some job characteristics (time pressure, growth at work, feedback) changed significantly. As a result job satisfaction changed as well.

Although these results support the research model some critical comments have to be made. Because the research model was used to study a number of principal effects, it can be stated that the model has simplified reality. At first, in the model the job characteristics are supposed to be concrete variables. In the paragraph describing the methodological reflections it was already mentioned that a difference can be made between subjective and objective job characteristics. Although objective and subjective job characteristics agree to a considerable extent; the agreement is not perfect: the perception of job characteristics is influenced by the social environment (Thomas \& Griffin, 1983). In this respect reference is also made to the study by De Jonge (1995). Following an extensive study, De Jonge (1995) formulates a model that makes a distinction between situational job characteristics and perceived job characteristics. In this model the perceived job characteristics are affected by psychological outcomes as well as by individual characteristics.

In addition a comment can be made about the moderating effect. In the research model only one moderator was included (i.e. type of nurse). It is also possible that other individual characteristics are relevant moderators. For example, it can be hypothesized that the variable 'preference for skill variety' moderates the effect of working with areas-of-special-expertise. Although other studies (see the reviews by Boumans, 1990 and Algera, 1993) did not yield conclusive support for moderating effects, it would seem worthwhile to incorporate more moderating effects in the research model.

A final comment is made about the variables of job satisfaction and burnout. In the research model these variables have been studied independently, whereas it is plausible to hypothesize that there is a relation between these two variables. This is supported by, for example the results of a meta-analytic study by Blegen (1993), that showed job satisfaction to be strongly and negatively related with stress. Consequently, to get more insight into the effects of work redesign, it is relevant to study the relationship between job satisfaction and burnout.

The comments show that the research model can be modified on several aspects. However, care must be taken to avoid models becoming needlessly complicated and to ensure they remain practicable for use in research. 


\section{Qually of care}

In redesigning work in health care: the quality of care must aways be in mind Chinges may not be made at the coct of the gatient. his is therefore important 10 snow ine ettects on the quality of care However, resaarch has shown that it is difficult ve messura effects on the quality of care For example vart Campen at al. (1902, 1985) showed thak the majority of patients, in seneral, hawe a jostive assessment of he prowision of care so the margin, within which the differences beween ine experimental and comparison sroup can ran is wery sman

In this dissertation an interview schedule was deveipped w measure the quality of care from a patients' perspective. Instead of asking patients wo what exten hey were satistied or not (l. gatient satisfaction), his study foeused on both expectakons about care (= the degree of impotance) as wo as the observation of care (= he degrea of presence).

Athough the moment of measurement (i.e. too eariy) was probably a reason for not finding effects of differentiated practice and specialization, this part of the study acquired a picture of the subjective standard on the basis of which the patient assesses the quality of care. This type of measurement gives information about the aspects that are considered important by patients and the aspects that need attention. For example, the patients in this study judged "expertise" as the most important quality aspect of community nursing care; and although the patients did not find it very important that they are cared for by the same carer, they did believe that nursing care is too often provided by different carers.

With regard to the instruments developed two comments are made. First, the questionnaire was based on several existing instruments and assessed by staff nurses. It was not developed based on input from patients. To enable the measurement of quality of care from the patients' perspective, patients should be involved in developing the instrument.

The second comment relates to the operationalization of quality of care by making a distinction between degree of importance and degree of presence can be argued. It is possible that patients do not make this distinction, and subsequently judge both dimensions in a similar way. Although this effect was minimized by using different formulations for the degree of importance and the degree of presence, it is a problem that needs to be studied further. Because of the introduction of the 'Quality-law for health care agencies' (Staatsblad, 1996), the concept of 'quality of care' has increasingly become a very important topic for research. 


\subsubsection{Practical implications}

In this dissertation differentiated practice and specialization (i.e. areas-ofspecial-expertise) have been studied from many perspectives: content, outcomes and implementation process. As a consequence it has yielded information about the conditions that are needed to implement differentiated practice and areas-of-special-expertise successfully. These practical implications are described in this paragraph with regard to differentiated practice, specialization and community nursing in general.

\section{Differentiated practice}

The aim of differentiated practice is to ensure that the work of nurses is carried out by the most appropriate nurse in the most appropriate way (Boston, 1990). This is becoming increasingly important because of Dutch government policy. In several policy documents (Ministry of Health, Welfare and Sports, 1995a, 1995b, 1996), efficient and effective use of personnel is stimulated by introducing competitive elements in health care in general and community nursing in particular. For example, the agencies for community nursing used to have a guaranteed budget, but this has been downsized by $35 \%$ within five years. The released financial means have become available for new (private) agencies for community care, and individual budgets, among other things, for patients to be able to buy health care wherever they want to (Ministry of Health, Welfare and Sports, 1996).

In this respect, the study showed the importance of appropriate use of methods for patient assignment. It is helpful in harmonizing the mix of staff (= supply) with the demand for care. In this study it became obvious that at this moment staffing is not congruent with the complexity of nursing situations. Undoubtedly, this is a consequence of the past (up to a few years ago Dutch agencies for community nursing had to meet the ratio of 3 community nurses to 1 community nurse auxiliary). Because this cannot be changed immediately, longitudinal use of methods for patient assignment are required to describe the desired mix of staff. Subsequently, the results can be integrated in the agency's personnel policy in order to improve efficient and effective use of personnel, and reduce costs.

Clear job profiles describing duties and responsibilities are indispensable in agencies for community nursing to be able to assign patients appropriately. To prevent discrepancy between practice and education, harmonization between agencies for community nursing and nursing schools is necessary. Developments in nursing education have to be taken into account. For example, in August 1997 a new nursing education system will be introduced in the Netherlands. The goal of this new system is to introduce more clarity between the different levels of nurses, nurse auxiliaries, carers and 
assistants. One of the premises of this new system is that a large proportion of direct nursing care has to be pertomed by nurse auxilaries rovalfication Committee, 1995). Another example is Found in the United kingdom, In this country the "Project 2000: a new preparation for practice' United Kingdom Central Council, 1986) has been implemented. Reseorch by Hallet at al. (1905) showed that district nurses and health vistors require adequate time, preparation and training to work with Project 2000 students. Project 2000 has caused considerable upheaval for the community nursing services, presenting them with these difficulties (Hallet of al, 1995).

The results of the instrument for patient assignment and developments at the national level with regard to nursing education and health policy indicate that many nursing activities should be perfomed by community nurse auxilianes and that they are able to do so. As a consequence, community nurses have to focus on the complex elements of nursing care, i.e. nursing assessment, diagnosis, detemination of the complexity of care, and implementation of complex nursing interventions. In addition, they can be held accountable for the care delivered by one team. Besides, they and can coordinate all the care delivered by different care givers in one patient-situation. Coordination of care is becoming an important issue in community health care, because patients are now discharged from hospitals more quickly and in a poorer state of health. Community nurses need to be given the opportunity to promote patient interests by coordinating all the care a patient receives from other disciplines and institutions such as general practitioners, home helps, social workers, nursing homes and hospitals. Last but not least, community nurses themselves have to use their capacities more adequately. Developments in health care demand community nurses with a market-oriented approach. In view of their educational level and expertise, community nurses have the capability to determine present and future care demands of their patients.

\section{Specialization}

Community nursing is also faced with changes requiring specialization. Hospital care and community nursing care come into contact more often. Transmural care is on the move (Ministry of Health, Welfare and Sports, 1996). Because of technological developments, patients are discharged from hospitals 'quicker and sicker'. In order to care for these patients specialized knowledge and skills have to be available among community nurses and nurse auxiliaries. There is no standard recipe for transmural care, but it is important that specialized care is delivered in a flexible way without breaking the continuity (Dekker committee, 1994).

In this study a kind of specialization was used to maintain and promote expertise at the basic level. Community nurses and nurse auxiliaries have the 
opportunity to obtain additional expertise and skills with regard to particular patient categories by means of areas-of-specialexpertise. From the point of view of 'quality of labour', areas-of-special-expertise are an improvement in the work of community nursing. These areas are created if specific care is requested in addition to basic care. The choice of these areas has to be based on patient categories and the demand for care in the catchment-area of the agency. For example, if there are only a few HIV-infected patients it is not efficient and effective to create an area-of-special-expertise for HIVinfected patients. The following patient categories can be considered for an area-of-special-expertise: chronic non specific lung diseases (CNSLD), cancer, diabetes mellitus, neurological disorders, the elderly'psycho-geriatrics, wound/colostomy care, rheumatism, and incontinence. Community nurses can choose to specialize in anyone of these areas, whereas nurse auxiliaries can only choose among areas related to elderly/psycino-geriatrics, incontinence or rheumatism. This distinction is made mainly on the basis of the complexity and expertise (this is congruent with the principle of differentiated practice).

In order to benefit from the areas-of-special-expertise as much as possible the agency has to support the implementation process in many aspects. The selection of community nurses and nurse auxiliaries has to be based on an application procedure. Two important selection criteria are: motivation and at least $60 \%$ employment (i.e. 24 hours a week). From the perspective of efficiency and efficacy it is not recommended to have all the areas represented in all teams. In line with this, it is recommended to select a limited number of motivated nurses and nurse auxiliaries for an area-ofspecial-expertise. Subsequently, these nurses can be given relatively more hours for their areas (e.g. 2-4 hours per week).

The head nurse is considered as the person who guarantees that these nurses and nurse auxiliaries can use the hours available for the areas-ofspecial-expertise. The clinical nurse specialist is indispensable in determining the content and in supervising the process of implementation of this kind of specialization. The clinical nurse specialist is expected to give support by means of on-the-job training, continuing educational programs, supervision and feedback. In addition the clinical nurse specialist has to ensure harmonization among all the different areas-of-special-expertise.

\section{Community nursing in general}

The results of this study showed that all the community nurses and community nurse auxiliaries participating in this study were less satisfied with their jobs and had more feelings of burnout after a period of one year. Since this tendency was seen in both the experimental and comparison groups, nursing practice has to take this into consideration and develop measures to 
prevent it. In respect to this it is recommended that special attention be paid to the quality of labour taking into consideration the aspects of job characteristics addressed in this dissertation.

Community nurses and community nurse auxiliaries are expected on the other hand to act as professionals who can think and act independently I autonomously, especially when their work includes the determination of actual and potential patient problems, and to take measures accordingly to relieve these problems.

Secondly, a comment is made directed at the community nurses and community nurse auxiliaries. Because they are direct involved in caring, they have an important task in signalizing patient demand and shortages in community nursing. This means that they have the options to participate in the developments of community nursing in an active and professional way. Support and stimulation in this is expected from trades unions.

\subsubsection{Recommendations for future research}

This study has yielded some interesting findings that can be used to answer the research questions in this dissertation. However, some answers are not satisfying and community nursing is confronted with new questions that have to be answered. Therefore future research is needed.

At first, it is recommended to study the effects of differentiated practice and areas-of-special-expertise over a longer period of time. In particular as regards the areas-of-special-expertise several years are needed before this type of specialization can become completely crystallized in nursing practice. Only longitudinal research can describe the real effects.

As regards the research model, additional research is recommended to study the effects of work-(re)design in more detail. In this respect attention has to be paid to: the difference between situational job characteristics and perceived job characteristics; the moderating effects of individual characteristics; and the relation between job satisfaction and burnout.

In addition, research has to concentrate on several developments in health care. In the Netherlands, all the agencies for community nursing have to merge with home help services (Ministry of Health, Welfare and Sports, 1996). As a consequence further research in respect of differentiated practice does not have to focus on community nursing alone.

Continuity of care is in addition an important aspect of care. Research into coordination and demarcation of care among different health professionals in the community and among different institutions is of great importance.

Furthermore, and in order to insure a level of quality, research addressing the introduction and evaluation of quality assurance measures is also needed. Since the patients' opinion is becoming more and more important in health care (see e.g. Staatsblad, 1996) it is necessary to have the patients' perspective on care. 
Finally, the Dutch government stresses the importance of integrated, independent and objective assessments in nursing (Ministry of Health, Welfare and Sports, 1996). In view of the government, functionaries employed by independent organizations have to assess all types of care (e.g. at home, in nursing homes, in homes for the elderly) by means of objective measures. In order to provide clarity about the capacities that are needed for this role, and to develop objective measures, research is recommended in this area. 


\subsection{References}

Algera, J.A. (1981). Kenmerken van werk (Job characteristics). Lisse: Swets \& Zeitlinger.

Algera J.A. (1983). 'Objective' and perceived task characteristics as a determinant of reactions by task performers. Joumal of Occupational Psychology 56, 95-105.

Algera J.A., H. Flier van der \& Kamp L.J.Th van der (1986). Causal modeling of quality of work. In: The Psychology of Work and Organization (Debus G. \& Schroiff H.W.) (pp. 175-182). Amsterdam: Elsevier Science Publishers.

Algera J.A. (1993). Taakkenmerken (Job Characteristics). In: Studenteneditie Nieuw handboek arbeids- en organisatiepsychologie (Edition for students New manual for job- and organization-psychology) (Drenth P.J.D., Thierry Hk \& Wolff Ch.J. de) (pp. 63-92). Van Loghum: Houten/Zaventem: Bohn Stafleu.

Bergers G.P.A., Marcelissen F.G.H. \& Wolf de Ch.J. (1986). VOS-D Vragenlijst Organisatiestress- $D$, Handleiding. (Questionnaire on Organizational Stress, Manual). Stressgroep publikatie 36.

Blegen M.A. (1993). Nurses' job satisfaction: a meta-analysis of related variables. Nursing Research 42(1), 36-41.

Boer H. de (1995). Complexiteit van zorg. Een vergelijkende studie naar de validiteit, betrouwbaarheid en hanterbaarheid van twee complexiteitsmeetinstrumenten (Complexity of care. A comparative study of the validity, reliability and practicability of two measurementinstruments for complexity). Maastricht: Rijksuniversiteit Limburg.

Boston C.M. (1990). Introduction. In: Current issues and perspectives on differentiated practice (pp.1-3). Chicago: American Organization of Nurse Executives.

Boumans N.P.G. (1990). Het werk van verpleegkundigen in algemene ziekenhuizen: een onderzoek naar werkaspeclen en hun invloed op verpleegkundigen (The work of nurses in hospitals: a study of job characteristics and their effects on nurses). PhD-thesis. Maastricht: Rijksuniversiteit Limburg.

Boumans N.P.G. \& Landeweerd J.A. (1993). Some problems concerning the measurement of job characteristics in nursing work. The European Work and Organizational Psychologist 2(4), 303-317.

Boyle A., Grap M.J., Younger J. \& Thornby D. (1991). Personality hardiness, ways of coping, social support and burnout in critical care nurses. Joumal of Advanced Nursing 16, 850-857.

Broadbent D.E. (1985). The clinical impact of job design. British Joumal of Clinical Psychology 24, 33-44.

Campbell D.T. \& Stanley J.C. (1963). Experimental and quasi-expenimental designs for research. Chicago: Rand McNally Publishing Co.

Campen C. van, Sixma H., Friele R.D., Kerssens J.J. \& Peters L. (1995). Quality of Care and Patient Satisfaction: a Review of Measuring Instruments. Medical Care Research and Reviow 52(1), 109-133.

Campen C. van, Friele R.D. \& Kerssens J.J. (1992). Methods for assessing patient satisfaction with primary care review and annotated bibliography. NIVEL bibliography no. 35 . Utrecht: NIVEL.

Dekker Committee (committee modernization curative care) (1994). Gede日lde zorg: betere zorg (Shared care: better care). Wateringen: Ammerlaan Grafische Groep.

Derckx E. Hollands L. \& Halfens R. (1993). Complexiteit van verpleegsituaties. Een meetinstrument voor de wijkverpleging (Complexity of nursing situations. A measuring instrument for community nursing). Tijdschrift voor Verpleegkundigen 24(23), 773-779.

Fawcett J. (1989). Analysis and evaluation of conceptual models of nursing. Philadelphia: F.A. Davis.

Hackman J.R. \& Oldham G.R. (1975). Development of the Job Diagnostic Survey. Journal of applied psychology 60, 2, 159-170 
Hackman J.R. \& Oldham G.R. (1976). Motivation through the Design of Work: Test of a Theory. Organizational Behavior and human performance 16, 250-279.

Hackman J.R. \& Oldham G.R. (1980), Work redesign. Massachuselts: Addison-Wesley Publishing Company, Inc..

Hallet C.E., Williams A., Orr J., Butterworth R. \& Collister B. (1995). The implementation of Project 2000 in the community: a new perspective on the community nurse's role. Joumal of Advanced Nursing 21, 1159-1166.

Hare J., Pratt C.C. \& Andrews D. (1988). Predictors of burnout in professional and paraprofessional nurses working in hospitals and nursing homes. Intemational Joumal of Nursing Studies 25(2), 105-115.

Jonge J. de, Janssen P. \& Landeweerd A. (1994). Effecten van werkdruk, autonomie en sociale ondersteuning op de werkbeleving van verplegenden en verzorgenden (Effects of workload, autonomy and social support on work-experience of nurses and nurse auxiliaries). Verploegkunde (1), 17-26.

Jonge J. de (1995). Job autonomy, well-being and health. PhD-thesis. Maastricht: Datawyse B.V. 1 Universitaire Pers.

Malloch K.M., Mitton D.A. \& Jobes M.O. (1990). A model for differentiated nursing practice. The Joumal of Nursing Administration 20(2), 20-26.

McGrath A., Reid N. \& Boore J. (1989). Occupational stress in nursing. International Joumal of Nursing Studies 26(4), 343-358.

Ministry of Health, Welfare and Sports (1995a). Zorg in het regeorakkoord. Bestuunlijk / wetgevend programme zorgsector 1995-1998 (Care in govemment agreements. Administrative / legis/ative program sector of care 1995-1998). Tweede Kamer der Staten Generaal, vergaderjaar 1994-1995, 24124, 's Gravenhage: Sdu Uitgeverij Plantijnstraat.

Ministry of Health, Welfare and Sports (1995b). Gezond en wel. Het kader van het volksgezondheidsbeleid 1995-1998 (Healthy and well. The framework of health care policy 1995-1998).

Tweede Kamer der Slaten Generaal, vergaderjaar 1994-1995, 24126, 's Gravenhage: Sdu Uitgeverij Plantijnstraat.

Ministry of Health, Welfare and Sports (1996). Stand van zaken beleidsvoomemens thuiszorg (Policy intentions for home care). Rijswijk: Ministry of Health, Welfare and Sports.

Mintzberg H. (1983). Structure in fives. Englewood Cliffs: Prentice Hall.

Murphy M., DeBack V. (1990). Myths and realities. In: Current issues and perspectives on differentiated practice (pp. 5-16). Chicago: American Organization of Nurse Executives.

National Council for Health Care (1988). Verploegkundig beroepsprofiel (Nursing profile). Zoetermeer: National Council for Health Care.

Parahoo K. \& Barr O. (1994). Job satisfaction of community nurses working with people with a mental handicap. Joumal of Advenced Nursing 20, 1046-1055.

Polit D.F. \& Hungler B.P. (1987). Nursing research. Philadelphia: J.B. Lippincott Company.

Primm P.L. (1986). Entry into practice: competency statements for BSNs and ADNs. Nursing Outhook 34(3), 135-137.

Qualification Committee (1996). Gekwalificeerd voor de toekomst. Kwalificatiestructuur en eindtermen voor Verpleging en Verzorging (Qualified for the future. Structure of qualification and final terms for Nursing and Caring). Zoetermeer: Qualification Committe.

Roberts K.H. \& Glick W.H. (1981). The job characteristics approach to task design: A critical review. Joumal of Applied Psychology 66, 193-217.

Schaufeli W. \& Dierendonck D. van (1994). Burnout, begrip gemeten. De Nederlandse versie van de Maslach Burnout Inventory (MBI-NL) (Burnout, measuring a concept. The Dutch version of the Maslach Burnout Inventory (MBI-NL)). Gedrag \& Gezondheid 22(4), 153-171.

Schreurs P.J.G., Willige G. van de, Tellegen B. \& Brosschot J.F. (1988). De Utrechtse Coping Lijst: UCL-handleiding (The Utrecht Coping List). Lisse: Zwets \& Zeitlinger.

Siefert K., Jayaratne S. \& Chess W.A. (1991). Job satisfaction, burnout, and turnover in health care social workers. Health and social work 16(3), 193-202. 
Staatsblad (1996). Wet van 18 januari 1996 betreffende de kwaliteit van zorginstellingen (Kwaliteitswet zorginstellingen) (Law of 18 January 1996 conceming the quality of health care agencies (Quality-law for health care agencies). 's Gravenhage: Sdu Uitgevers.

Thomas J. \& Griffin, R. (1983). The social information processing model of task design: A review of the literature. Academy of Management Review 8, 672-682.

TIl C. van (1993). Complexiteits-scorelijst: Validiteit, betrouwbearheid en bruikbaarheid voor de bepaling van het deskundigheisniveau van de hulpvertener (Complexity-scoring list: validity, reliability and practicability for patient-assignment). Maastricht: Rijksuniversiteit Limburg.

Til C. van, Halfens R. \& Hollands L. (1994). Deskundigheidsniveaus: gerelateerd aan complexiteit van wijkverpleegkundige zorg (Levels of expertise: correlation with complexity of nursing care). Verploegkunde (1), 28-38.

United Kingdom Central Council (1986). Project 2000: a now preparation for practice. London: UKCC.

Verheij R.A. \& Kerkstra A. (1992). Intemational Comparative Study of Community Nursing. Avebury: Aldershot.

Verran J.A. \& Reid P.J. (1987). Replicated testing of the nursing technology model. Nursing Research 36(3), 190-194.

Vrielink H. (1990). Deskundigheid op maat. Beleidsnola 10 en $2 \theta$ deskundigheidsniveau (The right expertise. Policy-document on first and second level of expertise). Amsterdam: Stichting Amsterdams Kruiswerk.

Wade B.E. (1993). The job satisfaction of health visitors, district nurses and practice nurses working in areas served by four trusts: year 1. Joumal of Advanced Nursing 18, 992-1004. 
Health care in general and nursing in particular are increasingly being confronted by terms like productivity, flexibility, effectivity and quality. Work redesign is a method of coping with these changes. This dissertation pays attention to differentiated practice and specialization (i.e. areas-of-specialexpertise) in community nursing. Differentiated practice focuses on the demarcation and harmonization between community nurses and community nurse auxiliaries. As regards specialization, attention is paid to what are called areas-of-special-expertise. This study investigates the effects of differentiated practice and areas-of-special-expertise on job characteristics, job satisfaction, burnout and quality of care.

In Chapter 1, the background to the study is given on the basis of recent developments. Demographic figures show that both the number and the percentage of the elderly in the population is increasing. Because the elderly make increasing and more intensive use of health care than younger people, the efficient and effective delivery of care is assuming great importance. One solution is provided by differentiated care. In addition to the demographical changes, the nature of health care problems are changing. For example, an increase is seen in cardiac diseases, various types of cancer, and neurological disorders. Further, technological changes make it possible to discharge patients from hospitals both 'quicker and sicker'. As a consequence, nurses with advanced nursing knowledge and skills are needed in community nursing. The use of areas-of-special-expertise creates options for coping with these changes. In addition, a brief description of differentiated practice and areas-of-specialexpertise shows that there are little data on the effects of these two types of work redesign. To obtain insight into this issue, eight research questions were formulated and answered in the following chapters.

Chapter 2 describes differentiated practice and areas-of-special-expertise in the Dutch community nursing on the basis on the results of telephone interviews of 58 agencies (response $=84 \%$ ). These interviews, held in 1991-1992, showed that in almost all agencies, a differentiation was made between two levels: community nurse and community nurse auxiliary. This distinction was based on the complexity of nursing care, the range of responsibility and a separation between curative and preventive care (adult/elderly care versus mother and child care). Although the complexity of nursing care is seen as an important distinguishing characteristic, in practice there are not always appropriate criteria to determine the complexity of care. As regards the differences in responsibility, the results show that community nurses in most agencies are responsible for 
the assessment and the formulation of nursing diagnoses. Both community nurses and community nurse auxiliaries are responsible for the planning. implementation, evaluation and continuity of care for the patients in their own caseload. In addition, this inventory study shows that in almost all (95\%) agencies community nurses regularly perform tasks below their level of expertise. In almost half (48\%) of the agencies community nurse auxiliaries perform tasks below their level of expertise, i.e. tasks that could be performed by certified home helps. Furthermore, variety in the work of first level nurses is diminishing: the all-round or generic concept is being abandoned and community nurses have to choose either mother and child health care or adult/elderly care. There is also an increasing interest in areas-of-special-expertise. This allows community nurses and nurse auxiliaries the opportunity to obtain special expertise and skills, to maintain it and to pass it on to colleagues.

Chapter 3 presents a review of the international literature as regards differentiated practice and specialization in nursing. Because both concepts are related to work-(re)design, the Job Characteristics Model constructed by Hackman and Oldham was used as framework. Using this model, the literature was studied with regard to the following variables: job characteristics, job satisfaction, burnout and quality of care. In addition to several descriptions of differentiated practice and specialization, this review shows a paucity in data as regards their effects in community nursing. To study these effects more systematically, a research model is presented at the end of this chapter. The research model suggests that several job characteristics will change when differentiated practice and areas-of-special-expertise are used. As a result job satisfaction, burnout, and the quality of care will change. Because the outcomes are also influenced by individual characteristics, these are taken into account as well. Since the effects of differentiated practice and areas-of-special-expertise can differ between community nurses and community nurse auxiliaries; this model also allows the moderating effect of 'type of nurse' to be studied.

In chapter 4 the difference between community nurses and community nurse auxiliaries are described with respect to the variables included in the research model. The results of this study are based on a questionnaire filled out by 310 community nurses and 92 community nurse auxiliaries (response $=91 \%$ ). In comparing the job characteristics the data show that the content of the work of community nurses is more attractive (they have higher scores on skill variety and task identity) but on the other hand nurses feel themselves more often on their own (they experience more pressure of time, they get less feedback and they experience less support from their head nurse). The scores on job satisfaction showed that both community nurses as well as community nurse auxiliaries are moderately satisfied with their job, and do not have exceptional feelings of burnout. When the community nurses and nurse auxiliaries are 
compared the results showed that community nurses are less satisfied with their work in general, their head nurse, task clarity and opportunities for growth at work. Furthermore, community nurses manifest more feelings of burnout.

Both job characteristics as well as individual characteristics were shown to be related to job satisfaction and burnout. Job satisfaction is positively effected by task clarity, skill variety, possibilities for growth and feedback at work. As regards burnout, it became obvious that time pressure increases feelings of burnout, whereas burnout is decreased by autonomy, skill variety, growth at work and task significance ( $=$ the degree to which the job has a substantial impact on the lives of other people in the immediate organization and in the world at large). In addition, the data showed that almost all the individual characteristics have a positive influence on job satisfaction and decrease feelings of burnout.

When community nurses and community nurse auxiliaries are compared the effects of job characteristics are the same; but, as regards individual characteristics, one difference was found in the support experienced from the head nurse in case of burnout, which was more important for nurse auxiliaries than for community nurses.

Finally, the results of this study showed that job satisfaction is affected to greater extent by job characteristics, whereas burnout is more a result of individual characteristics.

In chapter 5 an instrument is described for measuring the complexity of nursing care and assigning the appropriate care-giver (i.e. a community nurse or a community nurse auxiliary) to the patient. This instrument is based on several existing instruments for patient-assignment and the theoretical framework of Fawcett. In this instrument, several aspects are ordered within four categories: health status, the recipient of nursing interventions, recipient's significant others I the setting, and nursing interventions. Based on a test by 65 community nurses and the alterations that were subsequently made, the validity and reliability have been shown to be acceptable. This instrument for patientassignment was used in 1151 nursing situations. Analysis showed that staffing is not congruent with the nursing care requested. In $46 \%$ of the situations a community nurse is needed and in $54 \%$ a community nurse auxiliary. However, patient assignment in practice showed, that the amount of community nurse auxiliaries is not appropriate to meet the desired assignment. As regards the clinical utility and acceptability, the results showed some nurses found it difficult to use the instrument, because it obliged them to look critically at patient assignment. Other nurses, however, appreciated the fact that the instrument clarified patient assignment and encouraged discussion of it.

Chapter 6 pays attention to the effects of differentiated practice and areas-ofspecialexpertise in respect of the work of community nurses and nurse 
auxiliaries. A pre-test/post-test design was used. Nine agencies for community nursing participated in this study. In each of these agencies, two groups were formed. In one of the two groups an intervention was implemented (the experimental group). In addition, before the intervention and one year later a measurement point was planned (using a questionnaire) in both the experimental group as well as in the comparison group. As regards differentiated practice, the sample consisted of 178 community nurses and community nurse auxiliaries employed by three different agencies. Eventually, $55 \%$ of the experimental group and $70 \%$ of the comparison group participated in both the pre-test and the post-test. Comparison between experimental and comparison group did not show differences. After implementation of differentiated practice, community nurses were shown to experience less variety in their work and community nurse auxiliaries to be less satisfied with opportunities for growth in their work.

As regards areas-of-special-expertise, the sample was formed by 229 community nurses and community nurse auxiliaries employed by six agencies. Of the experimental group, $65 \%$ participated in both the pre-test as well as the post-test. For the control group this percentage was $59 \%$. Analysis of the results showed that the work of community nurses and community nurse auxiliaries was positively affected by areas-of-special-expertise. This type of work-redesign leads to less time pressure and more growth at work. As regards job satisfaction, a preventive effect was found. Job satisfaction among community nurses and nurse auxiliaries with an area-of-special-expertise had not decreased, whereas nurses and nurse auxiliaries without an area-of-specialexpertise had become less satisfied with their work.

As regards burnout for both types of work-redesign no significant differences were found.

Finally, comparison between pre-test and post-test showed a decrease of job satisfaction and an increase of feelings of burnout for the total group of community nurses and nurse auxiliaries participating in this study.

Chapter 7 pays attention tot the effects of differentiated practice and areas-ofspecial-expertise in respect of the quality of care. The perspective of the patient has been taken as the starting point. Accordingly, quality of care has been defined as the discrepancy between patient' expectations and perceptions of several aspects of care. The effects of the work redesign were determined on the basis of a comparison between an experimental $(n=103)$ and a comparison group $(n=108)$. Data analysis revealed very few differences. Possible explanations for this are the premature status of the projects and the fact that patients are usually (highly) satisfied. The margin in which differences between the experimental and comparison groups might occur is therefore very small. However, this method can provide a detailed picture of the subjective standards patients use to judge the quality of care. 
In the final chapter, chapter 8 , the results of this study are further discussed. The answers to the research questions are first summarized. In addition, the research method is considered critically. In line with this, attention is paid to the research sample (e.g. selection, response), the intervention, and the measuring instruments used. In this connection, theoretical reflections are made. On the results, the content of the concepts 'differentiated practice' and 'areas-ofspecial-expertise' are further described and both concepts are related to each other. Attention is also paid to the difference between areas-of-special-expertise for community nurses and community nurse auxiliaries, and the work of clinical nurse specialists. The concept of 'complexity' also receives attention in the difference between the complexity of a nursing situation and the complexity of nursing care. As regards the research model, it can be observed that the model is in principle usable in measuring the effects of differentiated practice and areas-of-special-expertise. However, it is a simplification of reality. Although suggestions are made for alterations, the research model should not become needlessly complicated. Finally, the concept quality of care is reflected upon theoretically.

Based on this, implications for the practice of community nurses and nurse auxiliaries are discussed in order to facilitate implementation of differentiated practice and areas-of-special-expertise. In this respect, a task exists for the agencies of community nursing, nursing schools, and community nurses and nurse auxiliaries.

Chapter 8 concludes with some recommendations for future research. At first, a study is recommended of the effects of differentiated practice and areas-ofspecial-expertise over a longer period of time, because of the time needed before the effects are completely crystallized in nursing practice. As regards the research model, additional research is recommended to study the effects of work-(re)design in more detail. In addition, research has to concentrate on several developments in health care. Accordingly research in respect of differentiated practice and areas-of-special-expertise has to focus not on community nursing alone but to include other care givers in the community as well. Subjects that need attention are co-ordination of care, case management, continuity of care, assessment of care and the quality of care. 
De gezondheidszorg in het algemeen en de verpleging in het bijzonder worden in toenemende mate geconfronteerd met begrippen als produktiviteit, flexibiliteit, doelmatigheid en kwaliteit. Functiedifferentiatie is een methode waarmee kan worden ingespeeld op deze veranderingen. In dit proefschrift wordt aandacht besteed aan verticale en horizontale functiedifferentiatie in de extramurale verpleging. Onder verticale functiedifferentiatie (differentiated practice) wordt verstaan de afbakening en afstemming van taken tussen de functies van wijkverpleegkundige en wijkverpleegster ${ }^{1}$. In het kader van horizontale functiedifferentiatie wordt aandacht besteed aan het werken met aandachtsgebieden (areas-of-special-expertise). Het doel van deze studie is het onderzoeken van de effecten van verticale en horizontale functiedifferentiatie op taakkenmerken, arbeidstevredenheid, burnout en kwaliteit van zorg.

In hoofdstuk 1 wordt de achtergrond van het onderzoek geschetst aan de hand van een aantal ontwikkelingen. Demografische cijfers tonen aan dat zowel het aantal als het percentage ouderen toenemen. Doordat ouderen over het algemeen meer en intensiever gebruik maken van de gezondheidszorg dan jongeren, is het in toenemende mate van belang dat de zorg op een efficiente en effectieve manier wordt verleend. Met behulp van verticale functiedifferentiatie wordt geprobeerd hierop een antwoord te geven. Naast demografische ontwikkelingen zijn epidemiologische veranderingen te zien waardoor de aard van gezondheidsproblemen verandert. $\mathrm{Er}$ is bijvoorbeeld een toename van hart- en vaatziekten, verschillende soorten van kanker en psychiatrische en neurologische aandoeningen. Daarnaast is het door technologische ontwikkelingen mogelijk om patienten eerder uit het ziekenhuis te ontslaan waarmee een toename in de gecompliceerdheid van verpleegsituaties is te verwachten. Voor de extramurale verpleging betekent dit, dat het verplegend personeel moet beschikken over specifieke kennis en vaardigheden. Het werken met aandachtsgebieden biedt hiervoor mogelijkheden.

Vervolgens worden in dit hoofdstuk de twee vormen van functiedifferentiatie kort omschreven. Uit deze beschrijving blijkt, dat slechts weinig gegevens bekend zijn over de effecten van functiedifferentiatie. Om meer zicht te krijgen op deze effecten zijn acht onderzoeksvragen geformuleerd die in de volgende hoofdstukken van dit proefschrift worden behandeld.

1 In navolging van hel Verpleegkundig Beroepsprofiel (NRV, 1988) wordt voor het tweede deskundigheidsniveau (de ziekenverzorgende) de term 'verplegster' gebruikt. 
In hoofdstuk 2 wordt een beschrijving gegeven van functiedifferentiatie in de extramurale verpleging in Nederland op basis van een telefonische enquête bij 58 organisaties (respons $=84 \%$ ). Uit de enquête, die in 1991-1992 is gehouden, blijkt dat binnen bijna alle organisaties een onderscheid wordt gemaakt tussen twee niveaus: wijkverpleegkundigen en wijkverpleegsters. Dit onderscheid is gebaseerd op de complexiteit van zorg, de omvang van verantwoordelijkheden en een scheiding tussen curatieve en preventieve zorg (volwassenenzorg versus ouder- en kindzorg). Hoewel de complexiteit van zorg als een belangrijk onderscheidend kenmerk wordt beschouwd, worden in de praktijk vaak geen geschikte en duidelijke criteria gehanteerd om de complexiteit van zorg vast te stellen. Met betrekking tot het onderscheid in verantwoordelijkheden blijkt, dat de wijkverpleegkundige in de meeste organisaties verantwoordelijk is voor het vaststellen van de verpleegkundige anamnese en de verpleegkundige diagnose. Ten aanzien van de planning, uitvoering, evaluatie alsmede continuïteit van zorg draagt de wijkverpleegster voor de aan haar toegewezen patiënten zèlf de verantwoordelijkheid. Uit dit inventariserend onderzoek blijkt tevens dat in bijna alle (95\%) organisaties wijkverpleegkundigen regelmatig taken beneden hun opleidingsniveau verrichten. Met betrekking tot de wijkverpleegsters blijkt dat zij in ongeveer de helft $(48 \%)$ van de organisaties taken verrichten die verricht zouden kunnen worden door gezinsverzorgenden. Vervolgens blijkt dat het all-round karakter van het werk van wijkverpleegkundigen verdwijnt: wijkverpleegkundigen moeten kiezen voor of de volwassenenzorg of de ouder- en kindzorg. Daarnaast bestaat een toenemende belangstelling voor het werken met aandachtsgebieden. Op deze manier worden wijkverpleegkundigen en wijkverpleegsters de mogelijkheid geboden om ten aanzien van een bepaalde patientencategorie specifieke kennis en vaardigheden te verwerven, te onderhouden en over te dragen aan collega's.

In hoofdstuk 3 wordt een overzicht gegeven van de internationale literatuur over verticale- en horizontale functiedifferentiatie in de verpleging. Aangezien functiedifferentiatie betrekking heeft op (her)verdeling van werk is het Job Characteristics Model van Hackman en Oldham als referentiekader gebruikt. Gebaseerd op dit model is de literatuur bestudeerd ten aanzien van de volgende aspecten: taakkenmerken, arbeidstevredenheid, burnout en kwaliteit van zorg. Naast een beschrijving van verschillende vormen van verticale en horizontale functiedifferentiatie blijkt uit deze studie, dat slechts weinig kwantitatieve gegevens bekend zijn over de effecten ervan in de extramurale verpleging. Om deze effecten op een systematische manier te bestuderen wordt aan het eind van dit hoofdstuk een onderzoeksmodel gepresenteerd Dit model veronderstelt dat taakkenmerken veranderen door de implementatie van verticale en horizontale functiedifferentiatie. Dit heeft gevolgen voor de arbeidstevredenheid. burnout en kwaliteit van zorg. Aangezien deze afhanke- 
lijke variabelen ook worden beïnvloed door individuele kenmerken worden deze in het model eveneens in beschouwing genomen. Daar de gevolgen van functiedifferentiatie verschillend kunnen zijn voor wijkverpleegkundigen en wijkverpleegsters, wordt met dit model ook het modererende effect van de variabele 'functie' onderzocht.

In hoofdstuk 4 wordt het onderscheid tussen wijkverpleegkundigen en wijkverpleegsters beschreven ten aanzien van de variabelen die zijn opgenomen in het onderzoeksmodel. De resultaten van dit onderzoek zijn gebaseerd op een schriftelijke enquête waaraan 310 wijkverpleegkundigen en 92 wijkverpleegsters hebben deelgenomen (respons $=91 \%$ ). Uit de vergelijking van taakkenmerken blijkt, dat het werk van wijkverpleegkundigen van de ene kant aantrekkelijker is (ze scoren hoger ten aanzien van afwisseling in het werk en het verrichten van verpleegkundige anamneses en diagnoses), maar van de andere kant voelen ze zich meer op zichzelf terug geworpen (ze ervaren meer tijdsdruk, ze krijgen minder feedback en ervaren minder steun van hun leidinggevende). Over het algemeen zijn zowel wijkverpleegkundigen en wijkverpleegsters tevreden met hun werk en vertonen ze geen afwijkende gevoelens van burnout. Als deze twee groepen met elkaar worden vergeleken blijken wijkverpleegkundigen minder tevreden te zijn met het werk in het algemeen, de leidinggevende, duidelijkheid en groeimogelijkheden in het werk. Daarnaast vertonen wijkverpleegkundigen meer gevoelens van burnout dan wijkverpleegsters.

Zowel taakkenmerken als individuele kenmerken blijken van invloed te zijn op arbeidstevredenheid en burnout. Zo blijkt de tevredenheid in het werk toe te nemen als sprake is van veel duidelijkheid, afwisseling, groeimogelijkheden en feedback. Gevoelens van burnout verminderen als sprake is van veel autonomie, afwisseling en groeimogelijkheden en als men weet dat het werk dat men verricht door anderen als belangrijk wordt beschouwd. De individuele kenmerken die in dit onderzoek zijn bestudeerd blijken bijna allemaal een positieve invloed te hebben op arbeidstevredenheid en gevoelens van burnout te verminderen.

Als wijkverpleegkundigen en wijkverpleegsters met elkaar worden vergeleken blijken de effecten van taakkenmerken vergelijkbaar te zijn, maar blijkt een verschil te bestaan ten aanzien van eén individueel kenmerk: met betrekking tot het verminderen van gevoelens van burnout is het ervaren van sociale ondersteuning door de leidinggevende voor wijkverpleegsters van grotere betekenis dan voor wijkverpleegkundigen.

Tot slot blijkt uit dit onderzoek dat taakkenmerken een grotere invloed hebben op de arbeidstevredenheid terwijl individuele kenmerken met name effect hebben op gevoelens van burnout. 
In hoofdstuk 5 wordt een instrument beschreven waarmee de complexiteit van de verpleegkundige zorg kan worden vastgesteld en kan worden bepaald welk type hulpverlener (een wijkverpleegkundige of wijkverpleegster) is gewenst. Dit instrument is gebaseerd op verschillende reeds bestaande toewijzings-instrumenten en het theoretisch kader van Fawcett. In dit instrument zijn verschillende criteria gerangschikt binnen de volgende vier categorieën: tekorten in de gezondheidstoestand van de patient, de ontvanger van het verpleegkundig handelen, de omgeving waarin de zorgontvanger zich bevindt en het verpleegkundig handelen. Op basis van een test door 65 wijkverpleegkundigen en de aanpassingen die vervolgens zijn verricht, kan worden geconcludeerd, dat de validiteit en betrouwbaarheid van het instrument redelijk zijn te noemen. Dit toewijzings-instrument is vervolgens gebruikt in 1151 patientsituaties. Uit de analyse blijkt, dat de personele bezetting in veel gevallen niet overeenkomt met de verpleegkundige zorg die is gewenst. In $46 \%$ van de situaties is een wijkverpleegkundige gewenst en in $54 \%$ een wijkverpleegster. Echter, uit de uiteindelijke patiënt-toewijzing blijkt, dat het aantal wijkverpleegsters vaak onvoldoende is om aan de gewenste inzet te kunnen voldoen. Met betrekking tot de hanteerbaarheid en acceptatie van het instrument blijkt, dat sommigen het moeilijk vinden om met een toewijzingsinstrument te werken, omdat men hiermee wordt verplicht kritisch te kijken naar de inzet van het verplegend personeel. Daarentegen beschouwen anderen dit als een welkome gelegenheid om met elkaar van gedachten te wisselen over een verantwoorde inzet van personeel.

In hoofdstuk 6 wordt aandacht besteed aan de effecten van verticale en horizontale functiedifferentiatie op het werk van wijkverpleegkundigen en wijkverpleegsters. Hiervoor is gebruik gemaakt van een pre-test/post-test quasi experimenteel onderzoeksdesign. Binnen negen afzonderlijke organisaties zijn twee groepen samengesteld waarbij een interventie heeft plaatsgevonden binnen éen van deze groepen (de experimentele groep). Daarnaast is voorafgaand aan de interventie en een jaar later een meting verricht (met behulp van vragenlijsten) bij zowel de experimentele als controle groepen. In het kader van verticale functiedifferentiatie zijn 178 wijkverpleegkundigen en wijkverpleegsters uit drie organisaties betrokken in het onderzoek. Uiteindelijk heeft $55 \%$ van de experimentele groep en $70 \%$ van de controle groep deelgenomen aan zowel de voor- als nameting. Vergelijking van beide metingen tussen beide groepen maken twee verschillen zichtbaar. $\mathrm{Na}$ implementatie van verticale functiedifferentiatie ervaren wijkverpleegsters minder afwisseling in hun werk en zijn wijkverpleegkundigen minder tevreden over groeimogelijkheden in hun werk.

In het kader van horizontale functiedifferentiatie (het werken met aandachtsgebieden) hebben zes organisaties deelgenomen en zijn 229 wijkverpleegkundigen en wijkverpleegsters benaderd. Van de experimentele groep heeft $65 \%$ 
deelgenomen aan zowel de voor- als nameting en voor de controle groep geldt een percentage van $59 \%$. Uit de analyse van de gegevens blijkt, dat het werken met aandachtsgebieden een positief effect heeft op het werk van wijkverpleegkundigen en wijkverpleegsters. Het leidt tot minder tijdsdruk en meer groeimogelijkheden in het werk. Ten aanzien van de arbeidstevredenheid lijken de aandachtsgebieden een preventieve werking te hebben. De tevredenheid is namelijk niet gedaald bij de hulpverleners met een aandachtsgebied, terwijl de hulpverleners zonder een aandachtsgebied minder tevreden zijn geworden. Met betrekking tot burnout zijn voor beide vormen van functiedifferentiatie geen verschillen gevonden.

Tot slot bleek overigens, dat de totale groep wijkverpleegkundigen en wijkverpleegsters aan het eind van het onderzoek minder tevreden zijn geworden en meer gevoelens van burnout zijn gaan vertonen.

In hoofdstuk 7 wordt aandacht besteed aan de effecten van de twee vormen van functiedifferentiatie op de kwaliteit van zorg. Hierbij is het perspectief van de patiënt als uitgangspunt genomen. Kwaliteit van zorg is geoperationaliseerd als de discrepantie tussen 'verwachtingen' over en 'waarnemingen' van verschillende aspecten van zorg. Door een vergelijking te maken tussen een experimentele $(n=103)$ en controle groep $(n=108)$ zijn de effecten van functiedifferentiatie bestudeerd. Analyse van de data leverde nauwelijks verschillen op. Mogelijke oorzaken hiervoor zijn het prille stadium waarin functiedifferentiatie zich binnen de organisaties bevond en het feit dat patienten over het algemeen een positief oordeel hebben over de kwaliteit van zorg. De marge waarbinnen de verschillen tussen de experimentele en controle groep zich zouden moeten voordoen is hierdoor erg klein. Door middel van deze benadering is echter wel een gedetailleerd beeld verkregen van de subjectieve standaard op basis waarvan het oordeel van de patiët is gebaseerd.

In het laatste hoofdstuk, hoofdstuk 8, worden de resultaten van het onderzoek nader besproken. Allereerst wordt aan de hand van de acht onderzoeksvragen een samenvatting gegeven van de resultaten. Vervolgens worden enkele methodologische kanttekeningen geplaatst bij de onderzoeksmethode. Hierbij wordt onder andere aandacht besteed aan de onderzoekspopulatie (w.o. selectie, respons), de interventie en de vragenlijsten die zijn gebruikt.

In aansluiting hierop worden de bevindingen in dit onderzoek vanuit een theoretisch perspectief beschouwd. Aan de hand van de resultaten wordt de inhoud van de concepten 'verticale en horizontale functiedifferentiatie' nader omschreven en worden de twee concepten met elkaar in verband gebracht. Tevens wordt aandacht besteed aan het verschil tussen horizontale functiedifferentiatie (wijkverpleegkundige of wijkverpleegster met aandachtsgebieden) en specialisatie (verpleegkundig specialist). Aan het concept 'complexiteit' wordt eveneens aandacht besteedt waarbij een onderscheid wordt 
gemaakt tussen de complexiteit van de verpleegsituatie en de complexiteit van de verpleegkundige zorg. Met betrekking tot het gehanteerde onderzoeksmodel wordt opgemerkt, dat het in principe is te gebruiken om de effecten van functiedifferentiatie te meten. Echter, het is een simplificatie van de werkelijkheid. Hoewel suggesties worden gegeven voor aanpassingen in het onderzoeksmodel, wordt niet aanbevolen om het model onnodig gecompliceerd te maken. Tot slot wordt de kwaliteit van zorg vanuit een theoretisch perspectief beschouwd.

Vervolgens zijn enkele aanbevelingen geformuleerd die kunnen bijdragen aan het welslagen van de implementatie van verticale en horizontale functiedifferentiatie in de praktijk. In dit kader is een rol weggelegd voor het management van de thuiszorgorganisaties, de verpleegkundige opleidingen en de wijkverpleegkundigen en wijkverpleegsters.

Het hoofdstuk wordt afgesloten met een aantal suggesties voor verder onderzoek. Voorgesteld wordt om onderzoek naar de effecten van functiedifferentiatie over een langere periode plaats te laten vinden, vanwege de tijd die het kost voordat het is uitgekristalliseerd in de praktijk. Nader onderzoek gericht op de relaties tussen taakkenmerken, individuele kenmerken, arbeidstevredenheid en burnout is gewenst om te komen tot een onderzoeksmodel waarmee de effecten van werk(her)verdeling in meer detail zijn te onderzoeken. Vervolgens verdient het aandacht om onderzoek naar functiedifferentiatie niet te beperken tot de verpleegkundige beroepsgroep, maar uit te bereiden naar andere groepen hulpverleners die werkzaam zijn in de extramurale zorg. Onderwerpen als zorgcoठrdinatie, casemanagement, continuïteit van zorg, indicatiestelling en kwaliteit van zorgt verdienen hierbij aandacht. 


\section{REFERENCES}

Aast M.M.G. van de, Boumans N.P.G. \& Landeweerd J.A. (1995). Correlaten van de kwaliteit van de verpleegkundige zorg. De relatie tussen de kwaliteit van de verpleegkundige zorgverlening enerzijds en de stressbeleving, tevredenheid van patiënten en tevredenheid van verpleegkundigen anderzijds (The relationship between quality of nursingcare and stressexperience, patientsatisfaction, and satisfaction among nurses). Verploogkunde (2), 71-82.

Algera, J.A. (1981). Kenmerken van werk (Job characteristics). PhD thesis. Lisse: Swets \& Zeitlinger.

Algera J.A. (1983). 'Objective' and perceived task characteristics as a determinant of reactions by task performers. Joumal of Occupational Psychology 56, 95-105.

Algera J.A., Flier H. van der \& Kamp L.J.Th. van der (1986). Causal modeling of qulity of work. In: The Psychology of Work and Organization (Debus G. \& Schroiff H.W.) (pp. 175 - 182). Amsterdam: Elsevier Science Publishers.

Algera J.A. (1993). Taakkenmerken (Job Characteristics). In: Studenteneditie Nieuw handboek arbeids- en organisatiepsychologie (Edition for students New manual for job- and organization-psychology) (Drenth P.J.D., Thierry Hk \& Wolff Ch.J. de) (pp. 63-92). Van Loghum: Houten/Zaventem: Bohn Stafleu.

Amelsvoort F. van, Slingerland P. \& Verkaar E. (1993) Op kwaliteit aangesproken. Beslismodel voor de inzet van menskracht (Talking about quality. Model of decision for staffing). Utrecht: NIZW.

American Organization of Nurse Executives (1990). Current issues and perspectives on differentiated practice. Chicago: American Hospital Association.

Barter M. \& Furmidge M.L. (1994). Unlicensed assistive personnel. The Joumal of Nursing Administration 24(4), 36-40.

Benner P. (1984). From novice to expert. Menlo Park, California: Addison-Wesley Publishing Co.

Bergen A. (1991). Nurses caring for the terminally ill in the community: a review of the literature. Intemational Joumal of Nursing Studies 28(1), 89-101.

Bergers, G.P.A., Marcelissen, F.G.H. \& Wolf Ch.J. de (1986). VOS-D Vragenlijst Organisatiestress-D, Handleiding (VOS-D Questionnaire Organization-stress-D, Manual). Stressgroep publikatie 36.

Blegen M.A. (1993). Nurses' job satisfaction: a meta-analysis of related variables. Nursing Research 42(1), 36-41.

Bleys C. (1986). Over de grenzen van de zorg vanuit een klinisch oogpunt (About the boundaries of care from a clinical point of view). Scripta Modico-Philosophica (2), 14-28.

Boer H. de (1995). Complexiteit van zorg. Een vergelijkende studie naar de validiteit, betrouwbearheid en hanteerbaarheid van twee complexiteitsmeetinstrumenten (Complexity of care. A comparative study of the validity, reliability and practicability of two messurementinstruments for complexity). Maastricht: Rijksuniversiteit Limburg.

Bond S., Rhodes T., Philips P. \& Tierney A.J. (1990a). HIV infection and community nursing staff in Scotland-1, experience, practice and educaiion. Nursing Times 86(44), 47-50.

Bond S., Rhodes T., Philips P. \& Tierney A.J. (1990b). HIV infection and community nursing staff in Scotland-2, Knowledge and attitudes. Nursing Times 86(45), 49-51.

Bond S., Rhodes T., Philips P., Setters J., Foy C. \& Bond J. (1991). Experience and preparation of community nursing staff for work associated with HIV infection and AIDS. Social Science \& Medicine 32(1), 71-76.

Boston C.M. (1990). Introduction. In: Current issues and perspectives on differentiated practice (pp. 1-3). Chicago: American Organization of Nurse Executives. 
Boswell C.A. (1992). Work stress and job satisfaction for the community health nurse. Joumal of Community health nursing 9(4), 221-227.

Boumans N.P.G. (1990). Het werk van verpleogkundigen in algemene ziekenhuizen: een onderzoek naar werkaspecten en hun invioed op verpleegkundigen (The work of nurses in hospitals: a study about job charactenistics and their effects on nurses). Maastricht: Rijksuniversiteit Limburg.

Boumans N.P.G. \& Landeweerd J.A. (1993). Some problems concerning the measurement of job characteristics in nursing work. The European Work and Organizational Psychologist 2(4), 303-317.

Bowyer C.K. (1986). The complex care team: meeting the needs of high-technology nursing at home. Home Healthcare Nurse 4(1), 24-29.

Boyle A., Grap M.J., Younger J. \& Thomby D. (1991). Personality hardiness, ways of coping, social support and burnout in critical care nurses. Joumal of Advanced Nursing 16, 850-857.

Bragt M.J.A.B. van (1993). Het gedifferentieerd en allround werken binnen de wijkverpleging. Een onderzoek bij Kruiswerk West-Brabant en Stichting Interkruis Noord-Kennemerland (Spocialization and non-specialization in community nursing. A study carried out at Kruiswork West-Brabant and Stichting Interkruis Noord-Kennemenland). Maastricht: Rijksuniversiteit Limburg.

Broadbent D.E. (1985). The clinical impact of job design. British Joumal of Clinical Psychology 24, 33-44.

Campbell D.T. \& Stanley J.C. (1963). Experimental and quasi-experimental designs for research. Chicago: Rand McNally Publishing Co.

Campen C. van, Sixma H., Friele R.D., Kerssens J.J. \& Peters L. (1995). Quality of Care and Patient Satisfaction: a Review of Measuring Instruments. Medical Care Research and Review 52(1), $109-133$.

Campen C. van, Friele R.D. \& Kerssens J.J. (1992). Methods for assessing patient satisfaction with primary care reviow and annotated bibliography. NIVEL bibliography no. 35. Utrecht: NIVEL.

Christiaans M.A.C., Hurkmans M.H.J.J., Hollands L. \& Boumans N.P.G. (1993). Invloed van het deskundigheidsniveau op de kwaliteit van zorgverlening in complexe verpleegsituaties (Effects of the level of expertise on the quality of care in complex nursing situations). Verpleogkunde (1), 27-37.

Cohen-Mansfield J. (1989). Sources of satisfaction and stress in nursing home caregivers: preliminary results. Journal of Advanced Nursing 14, 383-388.

Corcoran, S.A. (1986). Task complexity and nursing expertise as factors in decision making. Nursing Research 35(2), 107-112.

Corley M.C., Farley B., Geddes N., Goodloe L. \& Green P. (1994). The clinical ladder: impact on nurse satisfaction and turnover. The Joumal of Nursing Administration 24(2), 42-48.

Cowley S. (1993). Skill mix: value for whom? Health Visitor 66(5), 166-168.

Cumberlege J. (1986). Neighbourhood nursing - A focus for care. Report of the Community Nursing Review. London: Her Majesty's Stationery Office.

Curreri C.A., Gilley W.F., Faulk L. \& Swansburg R.C. (1985). Job satisfaction: hospital-based RNs versus home health care RNs. Nursing Forum 22(4), 125-134.

Dekker Committee (committee modernization curative care) (1994). Gedeelde zorg: betere zorg (Shared care: better care). Wateringen: Ammerlaan Grafische Groep.

Derckx E., Hollands L. \& Halfens R. (1993). Complexiteit van verpleegsituaties. Een meetinstrument voor de wijkverpleging (Complexity of nursing situations. A measuring instrument for community nursing). Tijdschrift voor Verpleogkundigen 24(23), 773-779.

Driessen C. (1994). Kwaliteitsmeting Thuiszorg (Home-care Quality Measurement). 's-Hertogenbosch: Unie van Katholieke Bonden van Ouderen (KBO).

Duddy I. \& Parahoo K. (1992). The evaluation of a community coronary specialist nursing service in Northern Ireland. Joumal of Advanced Nursing 17, 288-293. 
Durand I. (1989). Nurse/patient dependency in community nursing. Nursing Times 85(5), 55-57.

Dutch Organisation for Scientific Research (1992). Onderzoeksprogramma kwaliteit van Zorg 1992-1996 (Research-programme Quality of care 1992-1996). Nederlandse organisatie voor Wetenschappelijk Onderzoek, gebied medische wetenschappen.

Fawcett J. (1989). Analysis and evaluation of conceptual models of nursing. Philadelphia: F.A. Davis.

Fishbein M. \& Ajzen I. (1975). Belief, Attitude, Intention and Behavior: an Intraduction to Theory and Research.

Forsey L.M., Cleland V.S. \& Miller B. (1993). Job descriptions for differentiated nursing practice and differentiated pay. The Joumal of Nursing Administration 23(5), 33-40.

Gibbs I., McCaughan D. \& Griffiths M. (1991). Skill mix in nursing: a selective review of the literature. Joumal of Advanced Nursing (16), 242-249.

Griffiths J. \& Luker K. (1994). Community nurse attitudes to the clinical nurse specialist. Nursing Times 90(17), 39-42.

Groen B., Willemse N. \& Rijkschroeff R. (1990). Op zoek naar kwaliteitscriteria van do eerstelijnsgezondheidszorg vanuit het patientenperspectief (Searching for criteria for quality of extramural health care from the patient's perspective). Utrecht: Landelijk Overleg van Decentrale Patienten/Consumenten Platforms (LODEP).

Grypdonck M. (1995). Verplegen met diepgang (In depth nursing). Tijdschrift voor ziekenverpleging (7), 202-207.

Haaren E. van (1994). De expert: Carriere maken met de handen aan het bed (The expert: $A$ career at the bedside). MGZ 22(4), 26-28.

Habes V. (1995). Op zoek naar de gulden middenweg (Seeking the golden mean.) Tijdschrift voor Ziekenverpleging (19), 574.

Hackman J.R. \& Oldham G.R. (1980). Work redesign. Massachusetts: Addison-Wesley Publishing Company, Inc..

Hackman J.R. \& Oldham G.R. (1975). Development of the Job Diagnostic Survey. Journal of applied psychology 60(2), 159-170.

Hackman J.R. \& Oldham G.R. (1976). Motivation through the Design of Work: Test of a Theory. Organizational Behavior and human performance 16, 250-279.

Hackman J.R. \& Oldham G.R. (1980). Work redesign. Massachusetts: Addison-Wesley Publishing Company, Inc..

Hallet C.E., Williams A., Orr J., Buttenworth R. \& Collister B. (1995). The implementation of Project 2000 in the community: a new perspective on the community nurse's role. Joumal of Advanced Nursing 21, 1159-1166.

Handy J.A. (1988). Theoretical and methodological problems within occupational stress and burnout research. Human Relations 41(5), 351-369.

Hanrahan M.H. \& Lapré F. (1990). Project wijkziekenverzorgenden. Deskundigheden verdeeld (Project community nurse auxiliaries. Expertises divided). Bunnik: Landelijke Vereniging voor Thuiszorg.

Hardy M.A. (1993). Regression with dummy variables. Sage University Paper series on Quantitative Application in the Social Sciences, 07-093. Newburry Park, CA: Sage.

Hare J., Pratt C.C. \& Andrews D. (1988). Predictors of bunrout in professional and paraprofessional nurses working in hospitals and nursing homes. International Joumal of Nursing Studies 25(2), 105-115.

Harteloh P.P.M. \& Casparie A.F. (1991). Kwaliteit van zorg. Van eөn zorginhoudelijke benadering naar een bedrijfskundige aanpak (Quality of care. From a care-approach to a business-approach). 's-Gravenhage: Vuga/De Tijdstroom.

Haste F.H. \& MacDonald L.D. (1992). The role of the specialist in community nursing: perceptions of specialist and district nurses. Intemational Joumal of Nursing Studies, 29(1), $37-47$. 
Ministry of Health, Welfare and Sports (1995b). Gezond en wel. Het kader van het volksgezondheidsbeleid 1995-1998 (Healthy and well. The framework of health care policy 1995-1998). Tweede Kamer der Staten Generaal, vergaderjaar 1994-1995, 24126, 's Gravenhage: Sdu Uitgeverij Plantijnstraat.

Mintzberg H. (1983). Structure in fives. Designing effective organisations. Englewood Cliffs: Prentice Hall.

Moons M., Kerkstra A. \& Biewenga T. (1994). Specialized home care for patients with AIDS: an experiment in Rotterdam, The Netherlands. Joumal of Advanced Nursing 19, 1132-1140.

Moore T.F. \& Simendinger E.A. (1982). Organizational burnout: is your hospital on fire? Dimensions of Health Service 59, 17-18.

Mostert H. (1993). De complexiteit van de verpleegsituatie. Op zoek naar een meetinstrument (Complexity of the nursing situation. Looking for a measuring instrument). Tijdschrift voor Verploogkundigen 12, 408-413.

Moyer A. (1989). Caring for a child with diabetes: the effect of specialist nurse care on parents' needs and concerns. Journal of Advanced Nursing 14, 536-545.

Murphy M. \& DeBack V. (1990). Myths and realities. In: Current issues and perspectives on differentiated practice (pp. 5-16). Chicago: American Organization of Nurse Executives.

Nash A. (1993). Reasons for referral to a palliative nursing team. Joumal of Advanced Nursing 18, 707-713.

Nationaal Ziekenhuisinstituut - AortA. Functiedifferentiatie binnen de intramurale verpleging (Differentiated practice in hospitals). Utrecht: Nationaal Ziekenhuisinstituut - AortA.

National Council for Health Care (1988). Verploogkundig beroepsprofiel (Nursing profile). Zoetermeer: National Council for Health Care.

National Health Service Management Executive Value for Money Team (1992). The nursing skillmix in the district nursing service. London: HMSO.

National Association for Health Care (1994). Handboek gebruikersraadpleging (Handbook users guide). Bunnik: Landelijke Vereniging voor Thuiszorg.

National Association for Home Care (1995). Scenario-paper. Strategische koersbepeling van de thuiszorg-branche (Stratogic market-report for home care). Bunnik: National Association Home Care.

National Council for Health Care and Foundation of the Dutch Economic Institute (1988). De arbeidsmankt voor verplogkundigen en ziekenverzorgenden (Labour market for nurses and nurse auxiliarios). Zoetermeer: National Council for Health Care.

Netherlands Central Bureau of Statistics (1995). Statistical Year-book. 's-Gravenhage: Sdu/uitgeverij, Netherlands Central Bureau of Statistics.

Netherlands Central Bureau of Statistics (1990 and 1994). Vademecum of Health Statistics of The Netherlands. Voorturg/Heerlen: Netherlands Central Bureau of Slatistics.

Nollen C.L.M. Zorgkwaliteit van twoe deskundigheidsniveaus binnen complexe verpleegsituaties in de wijkverpleging (Quality of care by two levels of expertise in complex nursing situations in community nursing). Maastricht: Rijksuniversiteit Limburg.

Otto-Crefcoeur V. (1995). Het evaluatiemodel junior/senior (The evaluationmodel junior/senior). Tijdschnift voor Verploogkundigen (4), 114-118.

Oudenampsen D., Rijkschroeff R. \& Venne L. van de (1993). Kwaliteitscriteria van de eerste lijn en kwaliteitsbevordering door de decentrale patientenplatforms (Criteria for quality for extramural care and quality improvement by local patient-orgenizations). Amsterdam: Stichting Kohnstamm Fonds voor Onderwijsresearch SCO, 1993.

Ovretveit J. (1992). Health Service Quality: An Introduction to Quality Methods for Health Services. London: Blackwell Scientific.

Parahoo K. \& Barr O. (1994). Job satisfaction of community nurses working with people with a mental handicap. Joumal of Advanced Nursing 20, 1046-1055.

Parasuraman A., Zeithaml V.A. \& Berry L.L. (1985). A conceptual model of service quality and its implications for future research. Journal of Marketing 49, 41-50. 
Pascoe G.C. (1983). Patient Satisfaction in Primary Health Care: a Literature Review and Analysis. Evaluation and Program Planning 6, 185-210.

Peet R. van der (1995). De 'H' van HBO-V (The 'R' from RN). Tijdschrif voor Ziekenverpleging (4), 102-107.

Polit D.F. \& Hungler B.P. (1987). Nursing research. Philadelphia: J.B. Lippincott Company.

Post M.W.M., Arend I.J.M. van den, Dingemans P.J.M., Haas C.L. de, Horn G.H.M.M. ten, Linden B.A. van der, Londen J. Van, Schrijvers A.J.P., Staring M.A.T.M. \& Weert-Van Oene G.H. de (1993). Kwaliteit van de zorgverlening: het patientenperspectief (Quality of care: patient's perspective). Kwaliteit en Zorg (2), 50-60.

Primm P.L. (1987). Differentiated Practice for ADN- and BSN-Prepared Nurses. Joumal of Professional Nursing 4, 218-225.

Primm P.L. (1988). Implementation of differentiated practice through differentiated case management. Michigan Nurse (9), 33.

Primm P.L. (1986). Entry into practice: competency statements for BSNs and ADNs. Nursing Outlook 34(3), 135-137.

Primm P.L. (1990). Approaches and strategies. In: Current issues and perspectives on differentiated practice (pp. 17-34). Chicago: American Organization of Nurse Executives.

Qualifiaction Committee (1996). Gekwalificeerd voor de toekomst. Kwalificatiestructuur en eindtermen voor Verpleging en Verzorging (Qualified for the future. Structure of qualification and final terms for Nursing and Caring). Zoetermeer: Qualification Committe.

Riordan J. (1991). Prestige: key to job satisfaction for community health nurses. Public Health Nursing 8(1), 59-64.

Riportella-Muller R., Selby M.L., Salmon M.E., Quade D. \& Legault C. (1991). Specialty Roles in Community Health Nursing: A National Survey of Educational Needs. Public Health Nursing $8(2), 81-89$.

Roberts K.H. \& Glick W.H. (1981). The job characteristics approach to task design: A critical review. Joumal of Applied Psychology 66, 193-217.

Roe-Prior P., Watts R.J. \& Burke K. (1994). Critical care clinical nurse specialist in home health care: survey results. Clinical Nurse Specialist 8(1), 35-40.

Schaufeli W. \& Dierendonck D. van (1994). Burnout, een begrip gemeten. De Nederlandse versie van de Maslach Burnout Inventory (MBI-NL) (Burnout, measuring a concept. The Dutch version of the Maslach Burnout Inventory (MBI-NL). Gedrag \& Gezondheid 22(4), 153-171.

Schreurs P.J.G., Willige G. van de, Tellegen B. \& Brosschot J.F. (1988). De Utrochtse Coping Lijst: UCL-handleiding (The Utrecht Coping List: UCL-manual). Lisse: Zwets \& Zeitlinger.

Seymour E. \& Buscherhof J.R. (1991). Sources and consequences of satisfaction and disstatisfaction in nursing: findings fom a national sample. Intemational Joumal of Nursing Studies 28(2), 109-124.

Siefert K., Jayaratne S. \& Chess W.A. (1991). Job satisfaction, burnout, and turnover in health care social workers. Health and social work 16(3), 193-202.

Sixma H.J., Kerssens J.J., Campen van C. \& L. Peters (in press). Quality of care from the patients' perspective: a theoretical approach.

Smeets H. \& Peet R. van der (1995). Verschil moet er zijn (There has to be difference). Tijdschrift voor Ziekenverpleging (1), 24-27.

Soeken K.L. \& Prescott P.A. (1991). Patient intensity for nursing index: the measurement model. Research in Nursing \& Health 14, 297-304.

Staatsblad (1996). Wat van 18 januari 1996 betreffende de kwaliteit van zorginstellingen (Kwaliteitswot zorginstellingen) (Law of 18 January 1996 conceming the quality of health care agencies (Quality-law for health care agencies). 's Gravenhage: Sdu Uitgevers.

Steering committee future-scenario's (1987a). Ouder worden in de toekomst. Tussenbelans (Getting older in the future). Rijswijk: Steering committee Future-scenario's Healthcare. 
Steering committee future-scenario's (1990). Chronische ziekten in het jaar 2005. Deel 2 Scenario's over CARA 1990-2005 (Chronic diseases in the year 2005. Part 2 Scenario's about CNSLD 1990-2005). Houten/Antwerpen: Bohn Stafleu van Loghum.

Steering committee future-scenario's (1987b). Kanker in Nederland. Deel I Scenario's over kanker 1985-2000 (Cancer in the Nethenlands. Part I Scenario's about cancer 1985-2000). Rijswijk: Steering committee Future-scenario's Healthcare.

Steering committee future-scenario's (1992). Toekomstscenario's voor eorstelijnszorg en thuiszorg (Future-scenario's for extramural care and home care). Houten/Zaventem: Bohn Stafleu van Loghum.

Strasser S., Aharony L. \& Greenberger D. (1993). The patient satisfaction process: moving toward a comprehensive model. Modical Care Review 50(2), 219-248.

Strickland B. \& Neely, S. (1995). Using a standard staffing index to allocate nursing staff. The Joumal of Nursing Administration 25 (3), 13-21.

Sullivan P.J. (1993). Occupational stress in psychiatric nursing. Joumal of Advanced Nursing 18, $591-601$.

Taylor B. (1985). The effect of DRGs on home health care. New Jersey's experience suggests DRGs are increasing the need for home care for more acutely ill patients. Nursing Outlook (6), 288-289.

Tempelman C.J.J. (1987) Welbevinden bij ouderen: constructie van een meetinstrument (Welbeing among the elderly: construction of a meausuring instrumet). Groningen: Rijksuniversiteit Groningen.

Thomas J. \& Griffin, R. (1983). The social information processing model of task design: A review of the literature. Academy of Management Review 8, 672-682.

Til C. van, Halfens R. \& Hollands L. (1994). Deskundigheidsniveaus: gerelateerd aan complexiteit van wijkverpleegkundige zorg (Levels of expertise: correlation with complexity of nursing care). Verpleogkunde (1), 28-38.

Til C. van (1993). Complexiteits-scorelijst: Validiteit, betrouwbaameid en bruikbaarheid voor de bepaling van het deskundigheisniveau van de hulpverlener (Complexity-scoring list: validity, reliability and practicability for patient-assignment). Maastricht: Rijksuniversiteit Limburg.

Turton P. (1984). Nurses working in the community. Nursing Times 5, 40-42.

United Kingdom Central Council (1986). Project 2000: a new preparation for practice. London: UKCC.

Veen E. van der \& Grotenhuis R.B.M. (1995). De professional: lastig of nuttig voor een marktgerichte thuiszorgorganisatie? (The professional: exacting or useful for a market oriented home care organization?). MGZ 23(6), 26-29.

Verheij R.A.,Caris-Verhallen W.M.C.M. \& A. Kerkstra (1993). Integratie kruiswerk en gezinsverzorging. Envaringen ven hulpverteners en clienten (Integration of community nursing en home help services. Experiences from carers and clients). Utrecht: NIVEL.

Verheij R.A. \& Kerkstra A. (1992). Intemational Comparative Study of Community Nursing. Avebury: Aldershot.

Verran J.A. \& Reid P.J. (1987). Replicated testing of the nursing technology model. Nursing Research 36(3), 190-194.

Vorst-Thijssen A., Brink-Muinen A. van den \& Kerkstra A. (1990). Het werk van wijkverptogkundigen en wijkziekenverzorgenden in Nederland (The work of community nurses and community nurse auxiliaries in The Netherlands). Utrecht: NIVEL.

Vrielink H. (1990). Deskundigheid op maat. Beleidsnote $1 \theta$ en $2 \theta$ deskundigheidsniveau (The night expertise. Policy-document first and second tevel of expertise). Amsterdam: Stichting Amsterdams Kruiswerk.

Waal M.A.E. van der, Nievaard A.C. \& Casparie A.F. (1994). Patientenraadpleging bij twee gezondheidscentra in Rotterdam (Consultation of patients in two health care agencies in Rotterdam, The Netherlands). Rotterdam: Instituut Beleid en Management Gezondheidszorg. 
Wade B.E. (1993). The job satisfaction of health visitors, district nurses and practice nurses working in areas served by four trusts: year 1. Joumal of Advanced Nursing 18, 992-1004.

Walcott-McQuigg J.A. \& Ervin N.E. (1992). Stressors in the workplace: community health nurses. Public Health Nursing 9(1), 65-71.

Welsh Office, Department of Health (1987). Nursing in the community: a team approach for Wales. Report of the review of Community Nursing in Wales. Cardiff: Welsh Office.

Werner Committee (1991). In hoger beroep (In further appeal). Rijswijk: Ministry of Public Health.

Wiegers T.A. (1992). Evaluatie van modellen voor aansluiting tussen intramurale specialistische en extramurale verpleogkundige cara-zorg voor kinderen (Assessment of models for the interface between intramural specialist CNSLD care and extramural CNSLD nursing care for children). Utrecht: NIVEL.

Wijdeven C. (1989). Partners op verschillend niveau (Partners on different levels). Maastricht: Rijksuniversiteit Limburg.

Wiles R. \& Robison J. (1994). Teamwork in primary care: the views and experiences of nurses, midwives and health visitors. Joumal of Advanced Nursing 20, 324-330.

Wilson-Barnett J. \& Beech S. (1994). Evaluating the clinical nurse specialist. A review. Intemational Joumal of Nursing Studies 31(6), 561-571. 


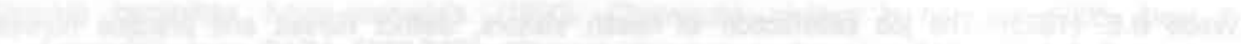

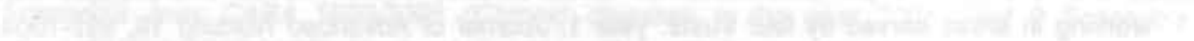

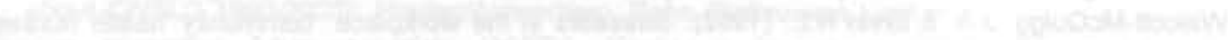

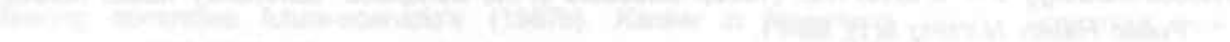

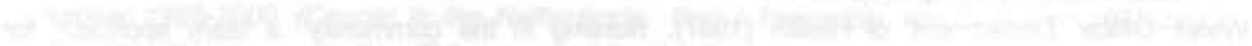

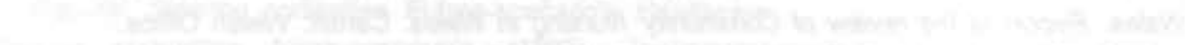

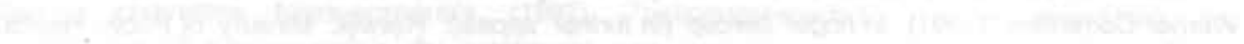
- 


\section{ACKNOWLEDGEMENTS}

Several people have played an important role in the completion of this dissertation. I will mention some of them here.

First of all, I would like to thank Huda Huijer Abu-Saad and Jouke van der Zee, my two dissertation supervisors. They encouraged me to start writing and finish this dissertation. Jouke and Huda, without your encouragement this dissertation would not have been completed.

Special thanks also to Ada Kerkstra, my co-supervisor. Ada, you were someone I always could rely on during my time at the NIVEL. I have appreciated working under your supervision and I am proud to be your first $\mathrm{PhD}$ graduate.

Furthermore, I want to thank all the community nurses, community nurse auxiliaries and staff nurses who participated in this study. The following agencies were involved: Kruisvereniging Rondom de Oosterschelde, Kruiswerk Noord-Oost Utrecht, Kruiswerk Rijn \& Duin, Kruiswerk WestVeluwe, Kruiswerk Zuid-West Friesland, Stichting Amsterdams Kruiswerk, Stichting Thuiszorg Amstelland en Meerlanden, Stichting Thuiszorg Brabant Noord-Oost, Stichting Thuiszorg Ommelanden and Thuiszorg De Bossche Meierij. Their participation made the study possible.

Many of my colleagues at the NIVEL provided me support and help in writing this dissertation. In particular, I want to thank Brigit Sluijk-Zonneveld for the speed and accuracy of her word processing, lay-out and transmission. Brigit, it was a pleasure to work with you. I am indebted to Harald Abrahamse and Jan Kerssens for their willingness to discuss statistical techniques with me. I want to thank my colleagues Dorine Collijn and Suzanne Arts, for their pleasant company, support and interest during my stay at the NIVEL. I want to thank Mieke Cornelius who designed the cover of this book.

I am also indebted to Stafford Wadsworth for his assistance in correcting my English.

I also wish to thank my current employer Hoeksma, Homans \& Menting and my colleagues. When I had a deadline, I was given the opportunity to spend extra time on the dissertation.

Thanks to my parents too. They have always given me the opportunity to develop my abilities. Together with my parents-in-law I am grateful to them for their warm interest and support at home.

Finally, I want to thank you, Karin. Your encouragement and comments, your love and understanding provided the right environment for me and my dissertation. The birth of our son Gydo provided an extra impulse in bringing this dissertation to a successful conclusion. 


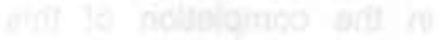

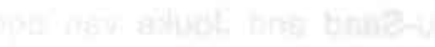

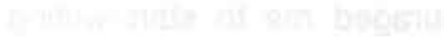




\section{ABOUT THE AUTHOR}

Patrick Jansen was born 21 June 1964 in Beltrum, the Netherlands. After completing high school (VWO) in 1982, he studied horticulture for one year in Utrecht. He also took for one year an in-service training course for psychiatric nursing in Wolfheze. Subsequently, he started nursing studies at the Hogeschool Enschede that resulted in the graduation as a registered nurse (BSN) in 1988. After this he worked for one year as a nurse in community nursing and psychiatric nursing. In 1989, he started to study health science with specialization in nursing science at the University Maastricht. After graduating in September 1991 he commenced work as a researcher at the Netherlands Institute of Primary Health Care (NIVEL) in Utrecht. This research focused mainly on differentiated practice and specialization in home care. Since August 1995 he has been employed by Hoeksma, Homans \& Menting in Enschede. As a management consultant he has been involved in several projects supporting organizations in the implementation of government health care policy. The structure of organizations with functionaries assessing all types of care (in an integral, objective and independent way) is currently the special focus of his attention. 
